\title{
第三回 講習會用講義
}

\section{第一日（8月 24 日）午前}

放射性同位元素大意

\section{1. 放射性同位元素關係の重要な墢見の年代}

1885. X線の發見（W. C. Röntgen)。

1896. ウラン監が放射線老出寸性質が西ると 亡在發見 (H. Becquerel)。

1898.トリゥム鹽が放射線老出す性質が西る ととを發見 (C. G. Schmidt と Mme Curie 各獨立江)。

18c8.ラ・ジッム及びポロニッムの發見（Curie 夫妻)。

1899. アクチニッムの發見 (A. Debierne)。

1900. ウランXの發見 (W. Crookes)。

1901. トリゥムXの發見（E. Rutherford 及 び F. Soddy)。

1902. 放射性元素壞變の法則つ墢見（E. Rutherford 及び F. Soddy, The disintegration Theory)。

1907. イオ二ッムの發見（B. B. Boltwood， 己 O. Hehn 各獨立江)。

1907，メソトリゥムの發見 (O. Hainn)。

1911. 同位元素 (Isotope) の名艘提菜 (F. Soddy)。

1912. 非放射性同位元素の發見(J. J. Thomson)。

1913. 放射性元素の變位律 (the displacement law of radioactive elements) の發見 (A. S. Russell, F. Soddy, K. Fajans 各獨立隹)。

1913. 放射性元素老指示藥 (radioactive indicator) 㐫るい注追跡者 (tracer) 之 して使用する最初の研究 (G. Hevesy 及び F. Paneth)。

1925. 放射性指示藥老化學分析化使朋与万範 圍の㩟大 (R. Ehrenbery)。
木 村 健 二 郎

1919. 元溸の人工轉換の成功 (E. Rutherford)。

1932. 中性子 (neutron) の發見（J. Chadwick)。

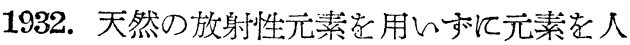
工的飞轉換すると己に成功（J. D. Cockroft 及び E. T. Walton)。

1934. 人工放射性元素の發、見 (Curie-Joliot 夫势)。

E. Fermi 中性子照射により多數の元 素につを人工放射性同位體索つくる。

E. O. Lawrence サイクロトロンによ り强民放射能西了人工放射性元素家つ くる。

1935. 人工放射性同位元素学追跡者として便 用する最初の研究 (G. Hevesy)。

1939. ウランの核分裂現象の發見 (O. Hahn 及び F. Strassmann)。

1940. 超ウラン元素の分離に成功 (E. McMillan 及び P. H. Abelson)。

1942. ウラン・グラファイトパイルによろ持續 的連鎖反應飞成功。

\section{2. 放射性元素壞變の法則}

放射性元素は放射線を出乙て他の元素に變わ る。Rutherford 亡 Soddy ほての現象を定量 的に取扱い，つぎの，ような䈓係を見出しを。

$$
\begin{aligned}
& N=N_{o} e^{-\lambda t}-\frac{d N}{d t}=\lambda N \\
& \text { こっに } N_{0} \text { は最初にあった放射性元素の原子 }
\end{aligned}
$$
數。 
原子數でこれととその時に存在するその放射性元 素の原子數こ比例する。

$\lambda$ 少壤變定數 disintegration constant い, 各放射性元素にそれぞれ特有の定數。

放射性元素の放射能の强さはそとにあるその 放射性元素の原子數に比例し，從ってその元素 の壊變速度に比例する。

壊變定數は乞つ放射性元素の半減期 $T$ (half-value period, 放射性元素の放射能, 從っ て放射性元紊の原子數か㵊初の本分飞減方るま で㴗する時閶つとの間につざの關係がある。

$$
\lambda=\frac{0.673}{T}
$$

\section{3. 同位元素}

Boltwood がイオニッムと命名した元素は化 學的性質 (及び光學的性質) がトリッムと全く等 しく, 唯異るの質量數之壞變定數である。 Hahn の發見したメソトリッムも化學的性質は 全くラジゥムに等しい。てのよう亿化學的性質 が全く等しく，從って元素の周期律表中で同じ 位置を占める元素に Soddy は同じ場所といら 意味を含んだ Isotope の稱を與えた。Isotope ほ同位元素委をは同位體亡譯されている。

同位元素注てのよらにして放射性元素に於て その存在を指摘さ秃たが，非放射性元素飞於て b Thomson が先ボネオンについて，次いで Aston が多數の元素について, 質量數を異にす る原子, 從って同位元素が存在するととを朋か にした。

\section{4. 放射性元素の變位徖}

1913 Russell 及びなお完成された形で同年 Soddy と Fajans 亿よりそれぞれ獨立に周期律 表中の放射性元素の位置飞ついて次の法則が發 表された。

（1）元素が $\alpha$ 線を出して壞變するときはで きる元素は周期律表で二つ低い位置沉るり （云いかえ礼ば原子番號が2だけ減じ），質 量數は 4 だけ減ずる。

（2）元素が $\beta$ 線を出して壞變するときは, できる元素忹周期律表で一つ高い位置汇な り（云いかえれば原子番號が1だけ增し）,
質量數は不變:である。

この法則沙っって元素の壞變系列が決定し， まを新しい放射性元素が發見されるなど重要な 影響があった。例えば UX, (Brevium) の發 見はこの法則を應用した結果でする。

\section{5. 放射分析, 放射性指示薬, 追跡者}

放射能を化學分析化應用するやり方汇 2 通り 西る。一つ放射性元素つ有する放射能測定 し，关の元素の分量を知るやり方でこれを放射 化學分析 Radioshemical Analysis という。他 の方法住放射性元素を所謂放射性指示藥㐫るい は追跡者として利用する場合で，乙㞦を放射分 析 Radiometric Analysis と呼んでいる。

放射性指示藥孝初めて研究江用いたの江 Hevesy こ Panethで, 彼等はての方法でク口 么酸鉛や硫化鉛の溶解度の測定索行った。郎ち 豫め鉛の放射性同位體であるラジゥム D を加え たクロム酸鉛あるいは硫化鉛をつくり，その飽 和溶液つ放射能を測定して溶液中の鉛の量を算 出した。乙礼は

（1）放射性同位體が安定注同位體と同じ化 學恕行動をとるてと,

（2）放射能の檢出は極めて 銳敏に行い得る 乙上

を利用して普通の方法では取扱いが困蜼を微量 の鉛を磪實に定量し得るととを示した最初の例 である。

ての方法に純粹な化學分析の場合につんては 後に Ehrenberg の研究により使用範圍が擴大 されをとは云え，一般には安定な同位體と放射 性同位體とぶ存在する元素の場合（鉛，ビスマ ス, タリッム), 及び弱い放射性同位體と强い放 射性同位體とが存在する元素の場合（ポロニ” ム，ラドン，ラジゥム，アクチニッム，トリゥム， プロタクチニッム）應用が限られているらら みがあった。乙かし，人工放射性同位元素の出 現によってての研究方法はひらく多數の元素沉 適用されるととになった。

\section{6. 最も普通な人工放射性同位元素をつくる 方式例}




$\begin{array}{ll}(\alpha, p) & (\mathrm{Z}-1)^{\mathrm{A}-3}+\alpha \rightarrow \mathrm{Z}^{\mathrm{A}}+\mathrm{p} \\ (\alpha, \mathrm{n}) & (\mathrm{Z}-2)^{\mathrm{A}-3}+\alpha \rightarrow \mathrm{Z}^{\mathrm{A}}+\mathrm{n} \\ (\mathrm{p}, \alpha) & (\mathrm{Z}+1)^{\mathrm{A}+3}+\mathrm{p} \rightarrow \mathrm{Z}^{\mathrm{A}}+\alpha \\ (\mathrm{p}, \gamma) & (\mathrm{Z}-1)^{\mathrm{A}-1}+\mathrm{p} \rightarrow \mathrm{Z}^{\mathrm{A}}+\gamma \\ (\mathrm{p}, \mathrm{d}) & \mathrm{Z}^{\mathrm{A}+1}+\mathrm{p} \rightarrow \mathrm{Z}^{\mathrm{A}}+\mathrm{d} \\ (\mathrm{p}, \mathrm{n}) & (\mathrm{Z}-1)^{\mathrm{A}}+\mathrm{p} \rightarrow \mathrm{Z}^{\mathrm{A}}+\mathrm{n} \\ (\mathrm{d}, 2 \mathrm{n}) & (\mathrm{Z}-1)^{\mathrm{A}}+\mathrm{d} \rightarrow \mathrm{Z}^{\mathrm{A}}+2 \mathrm{n} \\ (\mathrm{d}, \mathrm{n}) & (\mathrm{Z}-1)^{\mathrm{A}-1}+\mathrm{d} \rightarrow \mathrm{Z}^{\mathrm{A}}+\mathrm{n} \\ (\mathrm{d}, \alpha) & (\mathrm{Z}+1)^{\mathrm{A}+2}+\mathrm{d} \rightarrow \mathrm{Z}^{\mathrm{A}}+\alpha \\ (\mathrm{d}, \mathrm{p}) & \mathrm{Z}^{\mathrm{A}-1}+\mathrm{d} \rightarrow \mathrm{Z}^{\mathrm{A}}+\mathrm{p} \\ (\mathrm{n}, \gamma) & \mathrm{Z}^{\mathrm{A}-1}+\mathrm{n} \rightarrow \mathrm{Z}^{\mathrm{A}}+\gamma\end{array}$

$(\mathrm{n}, \alpha)$

$(\mathrm{Z}+2)^{\mathrm{A}+3}+\mathrm{n} \rightarrow \mathrm{Z}^{\mathrm{A}}+\alpha$

$(n, p) \quad(Z+1)^{A}+n \rightarrow Z^{A}+p$

$(\mathrm{n}, 2 \mathrm{n}) \quad \mathrm{Z}^{\mathrm{A}+1}+\mathrm{n} \rightarrow \mathrm{Z}^{\mathrm{A}}+2 \mathrm{n}$

7. 人工放射性同位元素の壞變形式例

$$
\begin{aligned}
& \mathrm{Z}^{\mathrm{A}} \rightarrow(\mathrm{Z}-2)^{\mathrm{A}-4}+\alpha \\
& \mathrm{Z}^{\mathrm{A}} \rightarrow(\mathrm{Z}+1)^{\mathrm{A}}+\beta^{-} \\
& \mathrm{Z}^{\mathrm{A}} \rightarrow(\mathrm{Z}-1)^{\mathrm{A}}+\beta^{+} \\
& \mathrm{Z}^{\mathrm{A}}+\mathrm{e}(\mathrm{K}) \rightarrow(\mathrm{Z}-1)^{\mathrm{A}}+\nu \\
& \mathrm{Z}^{\mathrm{Am}} \rightarrow \mathrm{Z}^{\mathrm{A}} \text { (Isomer) }+\gamma
\end{aligned}
$$




\section{第一日（8月 24 日）午前}

\section{放射線の测定}

\section{I. 原子の放射性壞變}

\section{1. 核種}

原子核 (atomic nucleus) 注陽子 (proton) 之中性子 (neutron) 之から構成されている。

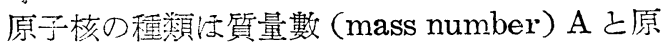
子番號 (atomic number) $\mathrm{Z}$ と汇よって區别さ 和る。質量數己注只つ核を構成す万陽子乞中性

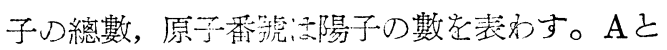
$\mathrm{Z}$ とで指定さ剠万特定つ種類の核或活々の原子 を記述するのに核種 (nuclide) といら語を用い る。核種を示寸記號としては，例元ば $A=16$,

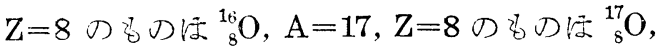
$\mathrm{A}=2, \mathrm{Z}=1$ のもの活 ${ }_{1}^{2} \mathrm{H}$ といらよう記す。

原子番號が共通后核, 郎ち同一元素の原子の 核注 1 種の核種行限ら和，質量數克異比する數

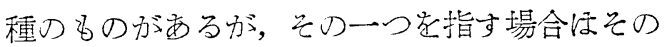
元素つ同位體（isotope）といら語者用いる。 Nuclide といら語泟 1947 年儿提唱された新し いるので，关礼案で注 isotope といら語がnu-

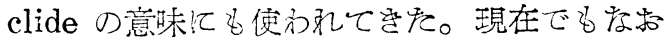
isotope といら語か潢く用いられているが，將 來注 “isotope”之“nuclide” 上注區別して

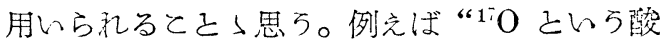
素刀 isotope”之いら云い方活正しいが，核の

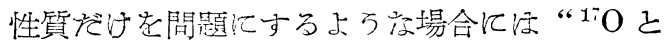
い5 isotope"といわ和，“17 $\mathrm{O}$ とい nuclide” といらべをで㐫る。

\section{2. 放射能}

自然界汸，例元ば ${ }_{92}^{23} \mathrm{U},{ }_{88}^{226} \mathrm{Ra},{ }_{83}^{21} \mathrm{Bi}(\mathrm{RaE})$ のように $\alpha$ 粒子 $(\mathrm{A}=4$ のへリゥム核 $(\mathrm{Z}=2))$ 或沶 $\beta$ 粒子(電子; 電子の質量江陽于の $1 / 1,800$, 正の電荷をるった陽電子亡, 負の電荷をもった

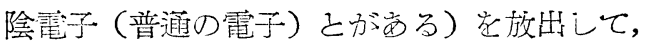
別存核種江變化す万性質老むっ它核橿が西る。
東大理學部百田光雄

とのような核種老放射性核種 (radioactive nuclide 或俚 radionuclide) と云い，乙の現象 老原子の放射性壞變 (radioactive disintegration) 或活放射性崩䘫 (radioactive decay) c (5。

天然存在す万放射性核種の外飞, 安定な核 種安中性子, 重陽子 $\left({ }_{1}^{2} \mathrm{H}\right), \boldsymbol{\gamma}$ 線等で衝擊して人 工的に放射性核種孛作り出すてとるでさる。

\section{中性子で衝擊して作られる放射性核種の例}

$$
\begin{aligned}
& { }_{7}^{1+} \mathrm{N}+\mathrm{n}(\text { 中性子 }) \rightarrow{ }_{6}^{1+} \mathrm{C}+\mathrm{p} \text { (陽于) } \\
& \text { 或社 }{ }^{1 \cdot 1} \mathrm{~N}(\mathrm{n}, \mathrm{p}){ }^{1 \cdot 4} \mathrm{C} \\
& { }_{20}^{40} \mathrm{Ca}+\mathrm{n} \quad \rightarrow{ }_{18}^{37} \mathrm{~A}+\alpha(ア ル フ ァ \text { 粒子 }) \\
& \text { 或活 }{ }^{*} \mathrm{Ca}(\mathrm{n}, \alpha){ }^{37} \mathrm{~A} \\
& { }_{27}^{5} \mathrm{Co}+\mathrm{n} \quad \rightarrow{ }_{27}^{61} \mathrm{Co}+\gamma \\
& \text { 或疗 }
\end{aligned}
$$

核分裂生成物 (fission product)： ${ }_{92}^{235} \mathrm{U}$ 或仼 ${ }_{94}^{233} \mathrm{Pu}$ 等の核分裂儿よってできる放射性核種, ${ }^{131} \mathrm{I},{ }^{91} \mathrm{Sr}$ 等の外多數亩る。

\section{重陽子で衝撃して作られる放射性核種の例}

$$
\begin{aligned}
{ }_{11}^{29} \mathrm{Na} & +{ }_{1}^{8} \mathrm{H} \longrightarrow{ }_{11}^{2 i} \mathrm{Na}+\mathrm{p}, \\
\text { 或活 } & { }^{23} \mathrm{Na}(\mathrm{d}, \mathrm{p}){ }^{2 \cdot 1} \mathrm{NA}
\end{aligned}
$$

$\alpha$ 崩壤：崩猿つ前後で核の質量數注 4 , 原子番 號は2光け減少する。

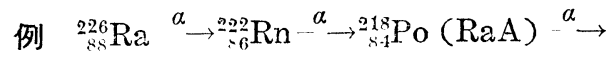

$\beta$ - 崩壤：院䤃于が放出される。原子番號は 1

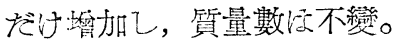

例 ${ }_{6}^{1} \mathrm{C} \longrightarrow{ }_{\mathrm{T}}^{1} \mathrm{~N}, \quad{ }_{5: 1}^{1: 1} \mathrm{I} \longrightarrow{ }_{54}^{1: 1} \mathrm{Xe}$

$\beta+$ 崩塆：陽電子が放出され方。原子番號性 1

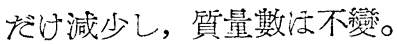

例 ${ }_{11}^{29} \mathrm{Na} \longrightarrow{ }_{11}^{20} \mathrm{Ne}$

K電子捕獲 ( $\mathrm{K}$ electron capture)：陽電子党 
放出する代りに，軌道琵子のらち最も核に

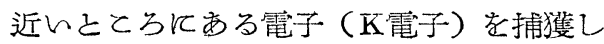
て原子番號が1だけ小さい核種（質量數は 不變）に變化する崩壞の樣式。これ标 $\beta^{+}$ 崩壞の1種である。ての場合崩壊でできた 原子注電子が缺けている雼沉, その位置 飞L電子が移って，その際 $\mathrm{X}$ 線 (K線) が 放出される。そのらちの何割か在L電子党 原子外には心゙出し，自からほ消减する。 (オージェ一效果 Auger effect)。

例 ${ }_{15}^{37} \mathrm{~A} \longrightarrow{ }_{17}^{37} \mathrm{Cl}$

\section{3. 半 減期}

原子の放射性埕變ひ統計的であって，サンプ 几中の放射性原子は一定時間內に泟一定の確率 で壊變を起す。從ってサンプル中の放射性原子 の數汪,壞變のために時間の經過と共に減少し, そのためにサンプル內で單位時間めたりに起る 壞變の數, 郎そのサンプルの放射能の强さ注時 間とともに減少する。年の有樣汇時刻考 $t$ (sec.) 亡乙時刻 $t=0$ 飞於ける放射能の强さを $R_{o}$,

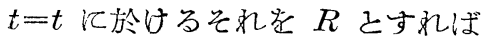

$$
R=R_{o} e^{-(\log 2) t / T}
$$

とい5式 (指數函數) で表わされ，てれ老圖示 すれば第 2 圖のようになる。

cの曲線を減衰曲線 (decay curve) とい 5。圖から制るよ5に放射能祊 $T$ という時間 がたつごとに半分に減少する。との時間を艺の

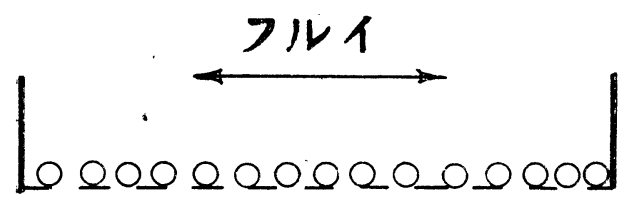

$$
10101
$$

第 1 圖 フルイの中に, 粒子がまばらに入ってい る場合，一定の時間 (あまり長くないとする) 內に落 ちる粒の數は, フルイの中にある粒子の數认比例す る。時か經過すると，フルイの中の粒子の數は減少 し, したがって, 同一時間內に落下する粒子の數も 減少する。

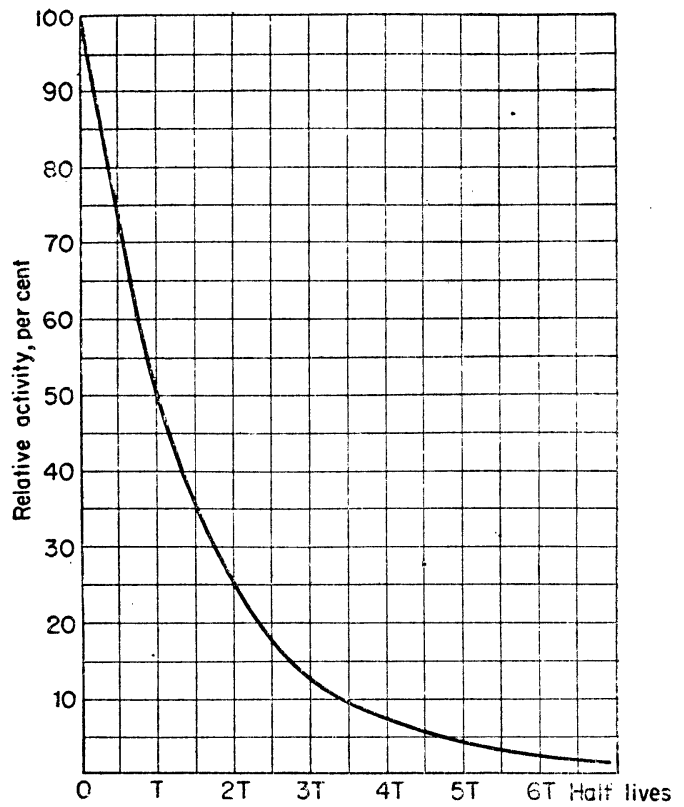

第 2 圆 放射能の減衰曲線

放射能の牛減期（half-life）之云い，各放射性 核種儿特有学量である。

(1）式の兩邊の對數をとれば

$$
\cdot \log \left(R / R_{0}\right)=-(\log 2) t / T
$$

亡存り $\log R$ 己時間 $t$ 己《淔線關係になる。

放射能の强さが時間がそつとぼのよう減る か㾁 (1) 式から計算する代りに第 3 圖のように 縱軸を對數で目盛った方眼紙(セミログ方眼紙) を用いて橫軸が $\mathrm{O} て ゙$ 緃軸が $R_{0}$ の點上，橫軸が $T$ で緃軸が $R_{o} / 2$ の點とを結ぶ直線索引けば， 任意の時刻 $t$ 亿於ける放射能の强さ $R$ 岩求め るととがで沓る。

サンプル內の放射性原子の數定 $N$ とする。 てれは時の經過之之もと變る量である。 $\Delta t$ 己い 5牛減期にくらべて短い時間內に崩培する原子 の數を $-\Delta N$ とすれば，單位時閒あたりの崩 壞の起万割合 $-\Delta N / \Delta t$ ほ，そのときサンプル 內に西る原子の數 $N$ 比例する。

$$
-\Delta N / \Delta t=\lambda N
$$

$\lambda$ ほ單位の時間 $(\Delta t \equiv 1)$ 內儿崩壇の起万雄率 一 $(\Delta N / N)$ 表表わす量で，壞變定數或怔崩壞定 數 (disintegration constant 或活 decay constant）とい5。（3）式を積分すると，

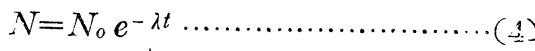




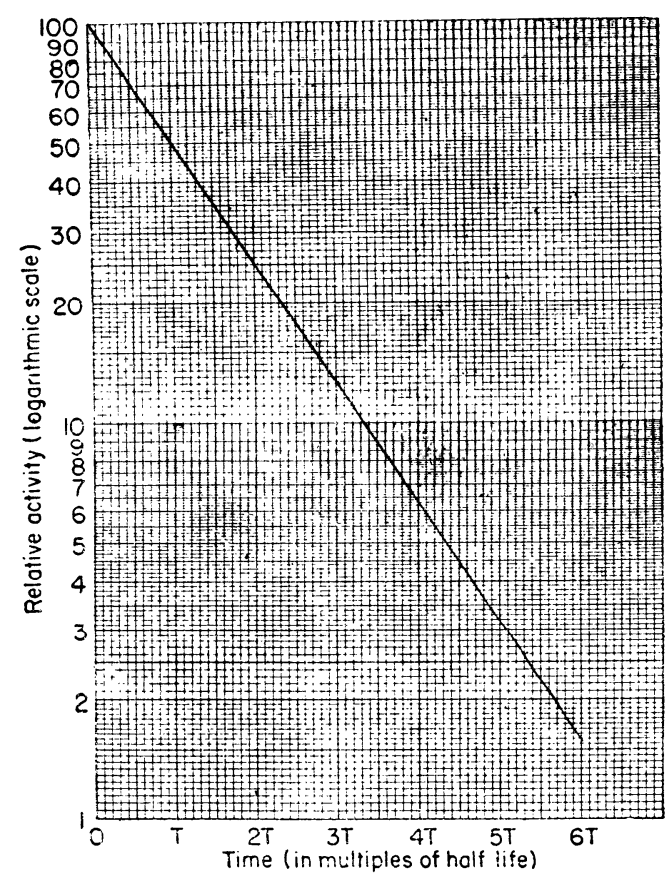

第 3 圖 對數目盛で表わした減䒾曲線

と索る。とっに $N_{0}$ 注 $t=0$, 郎ち時間老測り 始め夲時刻江存在した原子の數老表わす。放射 能の强度, 郎ち崩壞つおとる時間的割合 $R=$ $-\Delta N / \Delta t$ 注 (3) 式力ら

$$
R=-\Delta N / \Delta t=\lambda N
$$

であるから，(4) 式から

$$
R=R_{o} e^{-\lambda}
$$

となる。と、に $R_{0}$ 汪 $t=0$ 亿於ける放射能》 强さで

$$
R_{0}=-(\Delta N / \Delta t)_{t=0}=-\lambda N_{o}
$$

である。(6) 式の $\lambda$ の代りに

$$
T=-1 / \lambda \log 1 / 2=1 / \lambda \log 2=0.693 / \lambda \text { (8) }
$$

とおけば（1）式が得られる。

\section{4. 放射能の強さを表わす單位}

サンプルの放射能の强さ, 郎ちそのサンプル 內で單位時間當り（每秒）起万壞變の回數

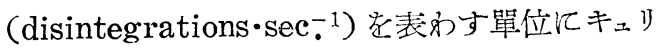
一 (curie) 上ラザフォード (rutherford) つ 2 種が两る。1キュリー之汸 $3.7 \times 10^{10}$ disintegration-sec-1 の放射能の强さで, 乙礼社元來 $1 \mathrm{~g}$. の ${ }_{8:}^{226} \mathrm{Ra}$ の放射能が 1 キュリーであるよ.万淀め たものである。

$$
\begin{aligned}
& 1 \text { ミリキュリー }(\mathrm{mc})=10^{-3} \text { キュリー(curie) } \\
& \text { 1マイクロキュリー }(\mu \mathrm{c})=
\end{aligned}
$$

$$
10^{-6} \text { キュリー (curie) }
$$

\begin{tabular}{|c|c|c|c|c|}
\hline & 放 射 總 & 牛 減 期 & $\begin{array}{l}a \text { 線或は } \beta \text { 線の工 } \\
\text { 唯 }\end{array}$ & $\begin{array}{c}r \text { 線のエネルギー } \\
(\mathrm{MeV})\end{array}$ \\
\hline${ }_{88}^{226} \mathrm{Ra}$ & $a, \gamma$ & 1,600 年 & 4.79 & 0.19 \\
\hline${ }_{\delta 2}^{211} \mathrm{~Pb}(\mathrm{RaD})$ & $\beta^{-}, \gamma$ & 22 年 & 0.026 & 0.047 \\
\hline${ }^{131} \mathrm{I}$ & $\beta^{-}, \gamma, \mathrm{e}^{-}$ & 8.0 日 & $0.60,0.32$ & $\begin{array}{ll}0.363, & 0.080 \\
0.638, & 0.283\end{array}$ \\
\hline${ }^{61} \mathrm{Co}$ & $\beta^{-}, \gamma$ & 5.3 年 & 0.31 & $1.10,1.30$ \\
\hline${ }^{32} \mathrm{P}$ & $\beta^{-}$ & 14.3 日 & 1.71 & no $r$ \\
\hline$\stackrel{2}{ } \mathrm{Na}$ & $\beta^{-}$ & 14.8 時 & 1.39 & $1.38,2.76$ \\
\hline${ }^{14} \mathrm{C}$ & $\beta^{-}$ & 5,100 年 & 0.156 & no $r$ \\
\hline
\end{tabular}

1 ラザフォード（rd）と注 $10^{6}$ disintegrations $\cdot$ sec $^{-1}$ の放射能の强さで, 從って

$$
1.0 \mathrm{mc}=37 \mathrm{rd}
$$

となる。

第 I 表 二·三の放射性核種の性質 
1キリューに相當する放射性原子の量 (サンプ ル中のその原子の數 (て秃老 $n$ とする), 或任 總質量（て质孝 $m$ で表わす）反牛減期 $T$ （從 って壞變定數入）とってきまる。

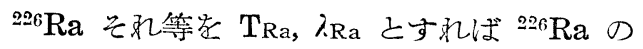
1g. 中の原子の數注 $6.06 \times 10^{23} / 226=2.68 \times 10^{21}$ であるから，

$$
\lambda_{\mathrm{Ra}} \times 2.68 \times 10^{21}=3.7 \times 10^{10}
$$

一方 $\lambda n=3.7 \times 10^{10}$ で㐫るべきであるから，

$$
n=\frac{\lambda_{\mathrm{Ra}}}{\lambda} \times 2.68 \times 10^{21}=\frac{T}{T_{\mathrm{Ra}}} \times 2.68 \times 10^{21}
$$

上教名。

例えば ${ }^{32} \mathrm{P}$ ほ坐減期が 14.3 日, ${ }^{226} \mathrm{Ra}$ の它 れ活 1,600 年であるので，

$$
n=\frac{14.3}{1,600 \times 365} \times 2.68 \times 10^{21}=6.58 \times 10^{16} \text { 個 }
$$

その總質量海 ${ }^{32} \mathrm{P}$ 原子の質量注 $\left({ }_{1}^{1} \mathrm{H}\right.$ 原子の質量) ×(筫量數) に压心゙等しんから

$1.66 \times 10^{-21} \times 32 \times 6.58 \times 10^{.6}=3.5 \times 10^{-6} \mathrm{~g}$. とをる。

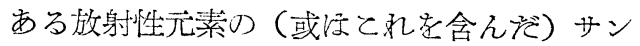
プルについて，その元素 $1 \mathrm{~g}$. 西たりの放射能 の强さ（キュリー/g.）学々のサンプルの比活性 度 (specific activity) そいら。サンプル中の 一つの元素の原子がずてて放射性であることも あるが，その元素の非放射性同位體（安定同位 體）之共存するという場合も甚歽多い。乙のよ 引な時皆活, 放射能の强さだけでなく, 比活性

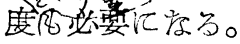

\section{5. 放射線のエネルギーを表わす單位}

放射線の粒子 1 個 1 個のエネルギー注霓子ボ ルト (electron volt) といら單位で表わされ る。1電子ボルト $(e v)$ とほ, 電子它 $1 \mathrm{~V}$ の電 位差で加速したときのェネルギーの嬶加量で, $1.60 \times 10^{-12}$ エルグに等しい。

1 電子ボルト (ev)

$$
\begin{aligned}
& =10^{-6} \text { メガ電子ボルト }(\mathrm{Mev}) \\
& =10^{-3} \text { キロ電子ボルト }(\mathrm{Kev}) \\
& =1.60 \times 10^{-12} \text { エルグ }
\end{aligned}
$$

$\gamma$ 線活 X 線乙同じく，電磁波であるがその 振動數を山(sec. $\left.{ }^{-1}\right)$ こすると, エネルギーがん
(エルグ）の光子 (photon) の流皇考えられ る。とつに $h$ ほ Planck の常數で $6.66 \times 10^{-27}$ エルグ秒で㐫る。 $\gamma$ 線の波長を $\lambda(\mathrm{cm}$.$) 上す机$ ば $\nu \lambda=c$ (光の速度 $)=3 \times 10^{1 /} \mathrm{cm}$. であるから， 光子のエネルギーは $h c / \lambda$ と表わされる。

\section{6. $\beta$ 線のエネルギー分布}

$\beta$ 崩壞の際飞放出される 第 4 圖のように0から，西万最高值まで連續な 分布它るっている。ての最高值性牛減期之とも 飞崩壤する核種の各ふ飞特長な量である。及際 のエネルギーとんらときには，ての最高値を指 すのが普通である。

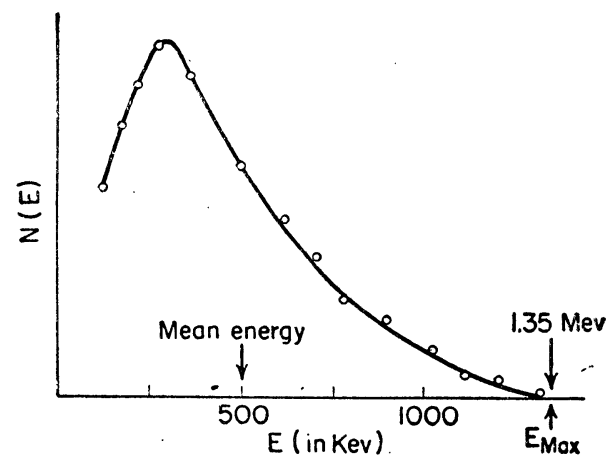

第 4 圖 $\beta$ 線のスペクトルの 1 例。 ${ }^{40} \mathrm{~K} の \beta^{-}$ス ペクトル。 ${ }^{40} \mathrm{~K}$ 保牛減期が $1.8 \times 10^{9}$ 年で天然存在 する $\beta$ 放射性核種でるる。

\section{7. $r$ 線を伴う崩壞}

$\alpha$ 崩壞, 或忹 $\beta$ 崩懐ででき它核が基底狀態 (ground state) でなく勵起狀態 (excited

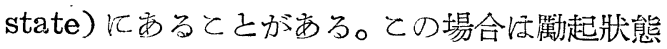
の核はエネルギーを $\gamma$ 線として放出し一，基底

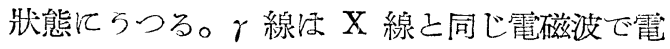
荷も質量も持っていない。 直後におてるのが普通で㐫る。（县性核轉移注 例外である。)

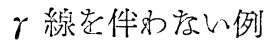

$$
{ }_{6}^{1:} \mathrm{C} \longrightarrow{ }_{7}^{1: \mathrm{N}},{ }_{15}^{32} \mathrm{P} \longrightarrow{ }_{16}^{32} \mathrm{~S}
$$

$\gamma$ 線学伴亏例

$$
{ }_{2 i}^{60} \mathrm{Co} \longrightarrow{ }_{28}^{60} \mathrm{~N}, \quad{ }_{53}^{121} \mathrm{I} \longrightarrow{ }_{5.4}^{191} \mathrm{X}
$$


${ }_{27}^{60} \mathrm{C}_{0}$

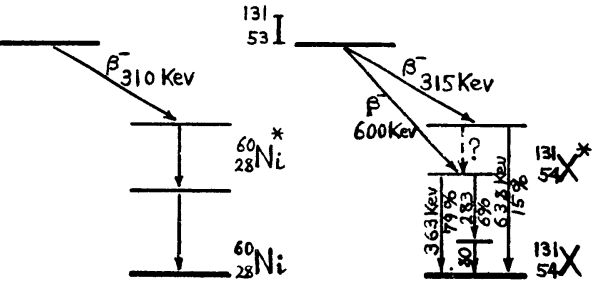

第 5 圆 ${ }^{60} \mathrm{Co},{ }_{53}^{131} \mathrm{I}$ の崩壤栐式。 $\mathrm{Ni}^{*}, \mathrm{X}^{*}$ はそれ ぞれの核の勵起狀態の記號である。

\section{8. $\gamma$ 線放出に關連する現象}

(1) 異性核轉移

勵起狀態の获が準安定 (metastable) で測定 できるよらな牛減期をるっているてこがある。 この上万核を異性核 (isomer) とい与，て机 が 線を放出して基底狀態にらつる轉移を異性 核轉移 (isomeric transition) とい」 $\mathrm{I} \cdot \mathrm{T}$ と いら記號で西らわす

$$
\begin{gathered}
\text { 例 }{ }_{30}^{69} \mathrm{Zn} * \frac{13.8 \text { 時 }}{\mathrm{I}} \rightarrow_{30}^{69} \mathrm{Zn}-\frac{59 \text { 分 }}{\beta^{-}} \rightarrow{ }_{31}^{69} \mathrm{Ga} \\
\\
{ }_{55}^{137} \mathrm{Cs} \frac{37 \text { 年 }}{\beta^{-}} \rightarrow{ }_{56}^{117} \mathrm{Ba}^{*} \stackrel{2.6 \text { 分 }}{\mathrm{I} \cdot \mathrm{T}} \rightarrow{ }_{56}^{137} \mathrm{Ba}
\end{gathered}
$$

（2）內部轉換

勵起核が $\gamma$ 線を放出して基底狀態汇移万代り に, その原子の核外電子にェネルギーを與えて,

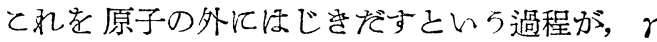
線の放出と平行して起る場合がある。てれを 線の內部轉換 (internal conversion) とい5。 放射能の表にはての上らな場合注 $\gamma, \mathrm{e}^{-}$という 上ら汇記されている。

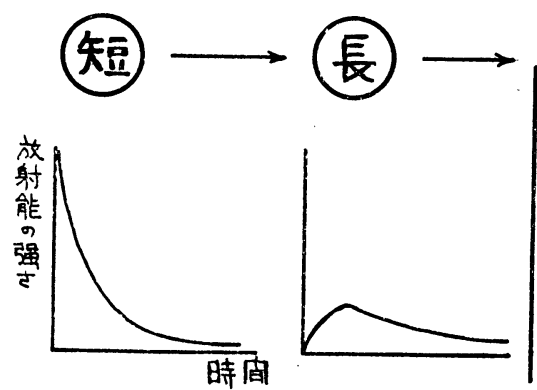

$\mathrm{A}$ の半減期力短办く $\mathrm{B}$ の本減期が 長い場合，Aはすぐ無くなってBに なってしまうので, 其の後は B はB の半減期で減少する。

\section{9. 逐次瓖變}

放射性壞變の結果できた核種がさらに放射性 である場合がある。第二の核種を第一の核種の 子供 (daughter) といら。更にてのととが數司 續くことる西る。乙れを逐次壞變（successive disintegration）とい5。天然の放射性物質の 多く, 核分裂生成物の多くはこの場合に屬する。 ての系列中の核種の放射能の時間的變化活，乙 れぞれの場合に計聖しなければならない。

てのうち特に重要なのほ系列の中に，牛減期

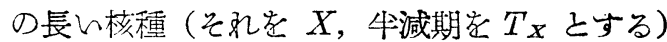
が更り，之礼汇つづく核種 $(Y, Z, \ldots \ldots)$ の牛減

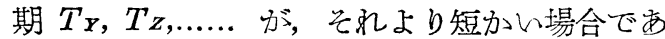
る。X妾とり出しておいておくと，サンプル中 に注次第に $Y, \mathrm{Z}, \ldots \ldots$ がた委ってくる。充分に 長時間がをつと，Yの量は，Xからできる增

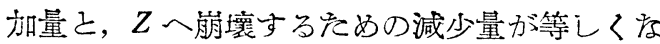
る狀態で平衡汇達する。

西万時刻汇的ける $X, Y, Z, \ldots \ldots$ の原子の數 を $N x, N x, N z, \ldots \ldots$ とす机ば，平衡狀態では

$$
\frac{N_{X}}{T_{X}}=\frac{N_{Y}}{T_{Y}}=\frac{N_{Z}}{T_{Z}}=\cdots \cdots
$$

この狀態では， $X$ の放射能の强さと，Yの放 射能とは等しくなり， $Y$ ほ見かけ上 $X$ の牛減 期で減少するてとに学る。 $Z$ 以下について子同 樣棉る。
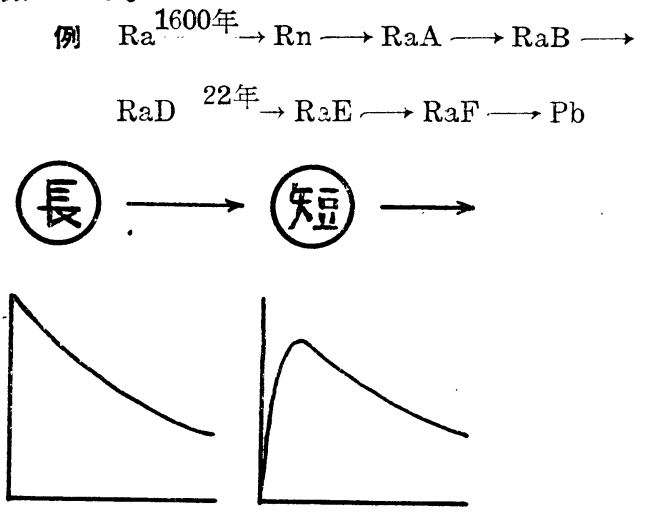

$\mathrm{A}$ の本減期か長く $\mathrm{B}$ の半減期が短 かい場合，Bはたえず A から補㭘を 受けているので, B の放射能は見加け 上，A の年減期で減少する。 


$$
\begin{aligned}
& { }^{9} \mathrm{Sr} \quad \text { 25年 } \rightarrow{ }^{9 r} \mathrm{Yt} \quad \text { 62特 } \rightarrow{ }^{9} \mathrm{Zr} \\
& { }^{1+4} \mathrm{Ce}{ }^{275}{ }^{27} \rightarrow \mathrm{Pr}^{175}{ }^{\text {分 }} \rightarrow{ }^{\mathrm{i}+} \mathrm{Nd}
\end{aligned}
$$

\section{0. 計數の統計的變動}

牛減期の長い放射線源索，をと忘ばガイガー 計數管の前飞お， $t$ 分の測定の結果， $n$ 之い 万計數が得られたとする。（牛減期が長いとい

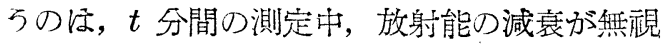
己れるとんら意味で西る。）ての場合，同じ測定 をくりかえして行らと, 同じ結果が得られをい のが一般で西る。（時間の測定の誤差，算え落 乙等がをいとしても）て礼梳前汇述べをら

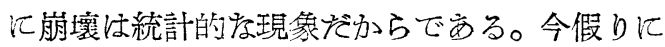
このよう存測定を多數団くり返しをとして，そ の結果の平均值が $れ$ にるる假定する。1国の 實測值 $n$ がての假想の平均值 $n$ から, ぞの位 はな礼を範圍內儿西るで西ららかというてとを 考える。とのよう楊合, $n$ の分布ほポイソン (Poisson) 分布飞なり, 偏差 $(n-\bar{n})$ の自乘の 本均值を $D$ そすれば， $n$ が小さな數でない場 合江社

$$
D=\overline{(n-n)^{2}}=\sqrt{n}
$$

となる。 $D$ 老標準偏差 (standard deviation) そいら。また，西る值より大きい偏差が表わ秃 る頻度と，その值よりる小さい偏差が表われる 頻度が等しんよら植 $P$ ほ

$P=0.67 D$

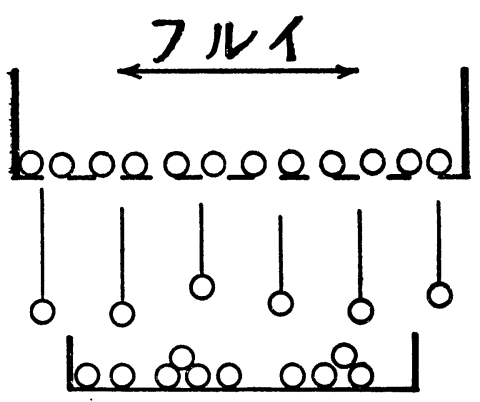

第 7 圖一定時間に受器の中に 落ちる粒の數に一定ではない。時 間を長くして, 受ける粒の數岂多く すると, その數值の信賴度は大きく なる。
となりて礼を老の probable error といら。 標準偏差や probable error 注本均值 $\bar{n}$ 江 對するもので，1 回の測定で活そのような量を

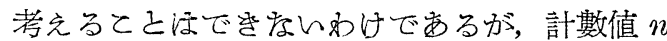
が小さい數で存い場合には， $n$ と $\bar{n}$ の差注大 きくないと期待されるので，その差定無視して

標準偏差 $D=\sqrt{ } n$

probable error $P=0.67 \sqrt{n}$

を, との值定值 $n$ の誤差の程度を袁独量と考 完,

$n \pm \sqrt{ } n$, 或注 $n \pm 0.67 \sqrt{ } n$

と表わす。

測定時間をのばして $n$ 老大きくすれば,標準 偏差は大をくなるが，それの $几$ 亿對する割合， 郎ち $I / n=1 / \sqrt{ } n$ 怔小さくなり, 測定值 $n$ の 信賴度は $\sqrt{n}$ 飞比例して大をくなる。例えば $D / N$ が $10 \%$ でよければ $n=100$ でよいが，

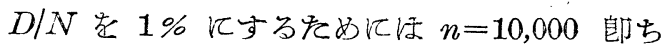
同じ條件の下でけ 100 倍の時間老要するここに なる。

計數の和, 差, 積, 商の誤差活最小自乘法飞 準じて行ら。

$n$ が $t$ 分間の測定値であり，气礼责 1 分間の 值 $n / t$ 湆算する場合, 標準偏差惊 $\sqrt{ } n / t$ で 西って、 $\sqrt{(n / t)}$ ではないてとに注意されたい， 李を，例えば 10 分間の測定值 $N_{0}$ 己，乙秃孝 1 分間交つに區切って 10 回行った測定值. $n_{1}$, $n_{2}, \cdots \cdots n^{10}$ の平均值の信賴度己袮等しい。 れは元來同一の測定操作绫からである。

\section{1. 計數のバックグラウンド}

ガイガー計數管等を使ら場合，サンプル走犆

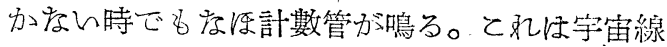
や，近傍汇ある放射性物質からの放射線が原因 で,ての計數定バックグラウンド計數 (background count）といら。サンプルによる真の計數 は測定值からバックグラウンド計數を差引いた もので西る。從って, バックグラウンドと同じ 位か，或活乞れより弱い上らをサンプル老測定 する場合には，特沉測定の㲳差汇ついて注意し なけ机ばをら存い。直徑 $2 \mathrm{~cm}$. 長さ $10 \mathrm{~m}$. のガ イガー計數管でバックグラウンド計數は每分50 位である。 
サンプルを置いて $t$ 分間測っをときの計數を $n$ ，サンプルをしで $t o$ 分測ったときの計數を noとする。サンプルによる1分間の計數 $R_{s}$ 注

$$
R_{s}=n / t-n_{o} / t_{o},
$$

$R$ : 江對する probable error $P_{s}$ 注

$$
I_{s}=0.67\left(n / t^{2}+n_{0} / t_{0}^{2}\right) \frac{1}{2}
$$

上なる。弱い放射能をはかる場合にはバックグ ラウンドを測る時間は少くともサンプル老測る 時間乙等しいか，或仿乞れより長くして，バッ クグラウンド計數の 誤美の 影響を小さくしな け剠ばなら度い。百分率で表わした $R_{s}$ の probable error 老 $f_{s}$ とすれば

$$
\begin{aligned}
& f_{s}=100 \times P_{s} / R_{s} \\
& t=t_{0} \text { の場合 } \frac{1}{2} \\
& \frac{1}{100} n_{0}^{\frac{1}{2}} f_{s}=0.67\left(n / n_{0}+1\right)^{\frac{1}{2}}\left[\left(n / n_{0}\right)-1\right]^{-1}
\end{aligned}
$$

上なり，ての式老圆示す礼ば第 8 圖のよう沉孛 る。

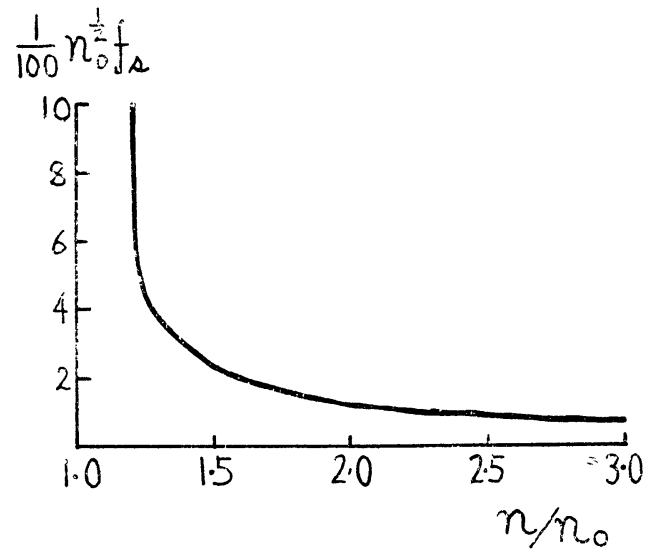

管 8 圖

今バックグラウンド計數が每分 60 , サンプル による計數於汽の牛分で，每分 30 の之季， $\left(n / n_{0}=1.5\right), 1 \%$ の精荠でてい側在測定するた め汇涪上国が

$$
\frac{1}{100} n_{0}^{\frac{1}{2}}=2.1
$$

從。て

$$
n_{0} \fallingdotseq 4 \times 10^{4}
$$

印方 $t=t_{o}=\frac{n_{o}}{60} \div 700$ (分)

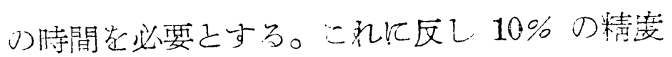

で滿足するとす礼ば，1/100 の時間，郎ち 7 分 でよいととになる。てのよらに精度をに倍にあ げるため注， $k^{2}$ の時間索要する。

\section{II. 放射線と物诈との交互作用}

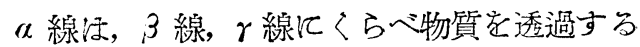
能力が小さく，檢出方法が比較的簡單でをい。 また人工放射性核種飞， $\alpha$ 放射能をbっ灾子D が少くない等の理由から， $\alpha$ 放射能索應用する とと注あるり多くない。とれで，て小では 線, $\gamma$ 線の性質につんて述べてとにする。

\section{1. $\beta$ 線}

$\beta$ 線の進路㳊第 9 圖のように，吸收體(absorber）老お人，一部のもの活大射方向と反對 の方向汇もどってくる。て秃は表面で反射され るので注なく，吸收體の中で原子己衝笑して， 進行方向学變えられて，出てくるので西る。て れ屴後方散亂（back scattering）とい5。吸 收娟の厚さ老增す之, 後方散亂の量泳, 初めの

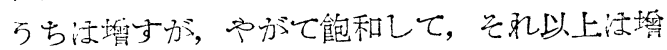
さなくなる。飽和する厚さほ，後にのへろ最大

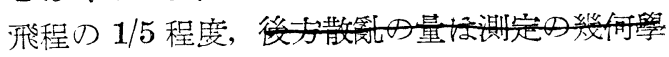

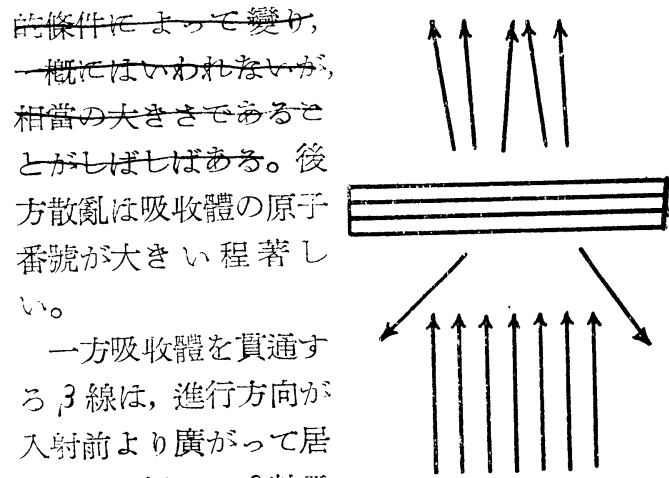

b, 且つ個↔の $\beta$ 粒二” についてみれば，规の

筑 9 僈 エネルギーは大射前上り小さくなっている。大 射了線のエネルギー分布洋前汇のべをよらに， 溥續分布であるから，エネルギーの小さね成分 法，すで吸收體の中で，エネルギー范失って 乙委って貫通するてと涺できない從って貫通 した線の量注入射前より減少している。吸收

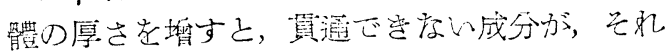

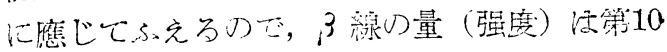


圖のよ5飞減少し，西る吸收體の厚さのとてろ で零になる。との厚さを，索に $\beta$ 線の最大飛 程 (maximum range) といら。元來 $\beta$ 線中の

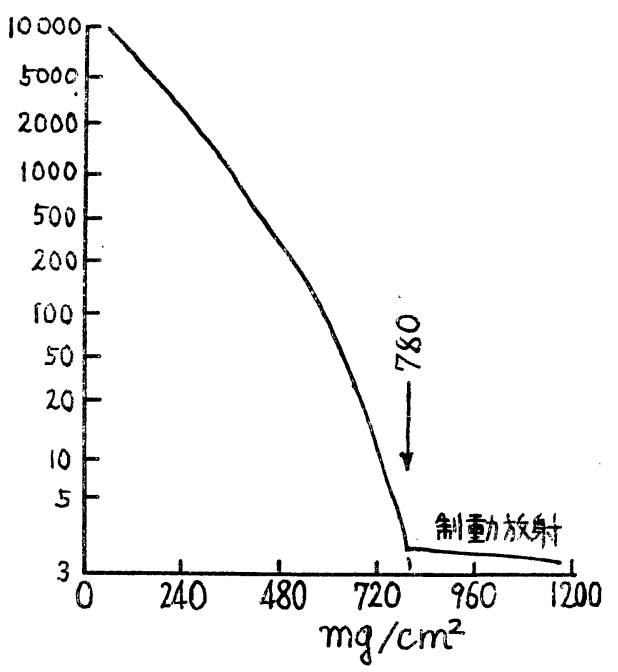

第10圖 ${ }^{32} \mathrm{P} の \beta$ 線の Al による吸收曲線。 潩軸は吸收體の厚さを, $1 \mathrm{~cm} .2$ あたりの質量 (mg.)で表わしてもる。縱軸惊對數目盛であるこ そに注意されたい。

あろエネルギーの粒子についで注目すれば，己

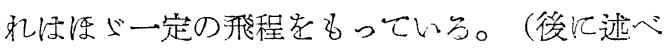
るよう江，實際に汪，進路がデグザグで西るた めに，個くの粒子の飛程汇注かなりの變動があ る。）從って吸收曲線注，その飛程の所孚では， ほ心゙一定の值を保ち，元てで急汇零汇なるわけ

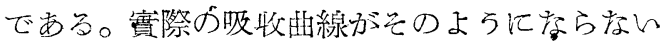
の任，上飞も述へたよらに $\beta$ 線が連續なエネル ギー分布をもっているからで者方。最大飛程活

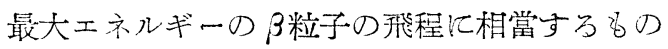
である。

$\beta$ 線の最大飛程上エネルギーの關係怔, $\mathrm{Al}$ 亿 ついて，次の關係で表わされる。

$$
\begin{aligned}
R & =0.542 \mathrm{E}-0.133 \quad E>0.8 \mathrm{Mev} \\
R & =0.407 \mathrm{E}^{1.3 \hookrightarrow} \quad 0.8 \mathrm{Mev}>E>0.15 \mathrm{Mev}
\end{aligned}
$$

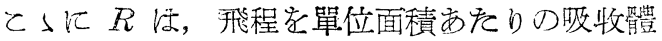
の質量 (比重 $\left(\mathrm{g} . \mathrm{cm}^{-8}\right) \times$ 厚さ $\left.(\mathrm{cm}).\right)$ で表わし そ值，巨はェネルギーを $\mathrm{Mev}$ で表わした值で ある。この式老 Feather の式とい5。最大飛

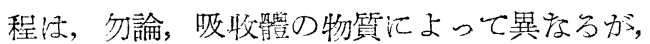

それを單位面積あたりの筫量で表わした值は，

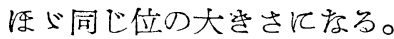

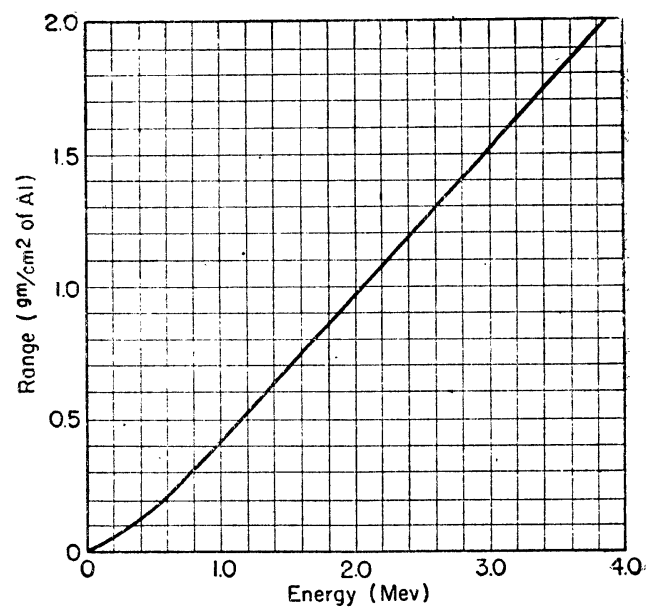

第 11 圆 $\mathrm{Al}$ 中の $\beta$ 線の最大旅程とエネルギ 一の關係。

サンプルの $\beta$ 放射能が，ぼのよう崖核種汇よ 万か不明であるとを，气の最大飛程䘮測定し，

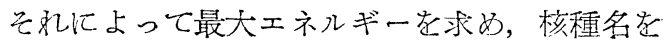
知ることがでさる。

$\beta$ 粒子が物質の中老進行するとき，原子と衝 突して起す過程注, 次の四つが主虑ものである。

（1）原子の軌道電子乙衙突して，てれを柱し き飛して，原子克電離する。乙の際 $\beta$ 粒子

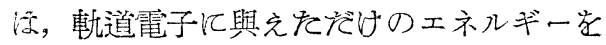
失々，且つ進行方向老多少變え万。

（2）上之類似恬現象で, 原子を電離する代り 汇傦起する。

との二つの過程で失らェェネルギー注，できた イオン 1 個あたり $30 \mathrm{ev}$ 程度の割合である。

（3）核の近傍孛通るとさ,核の電荷のをめ進 路を恋げられる。

（4）核のため減速され，エネルギーを失ら。 そのエネルギー注X線として放出される。

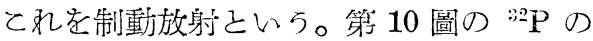
吸收曲線の最大飛程から先の, 吸收されに く放射線活 ${ }^{32} \mathrm{P}$ の $\beta$ 線が, 線源の中, 或 は吸收體の中で放出した制動放射で西る。 乙礼等の過程の起り方买, 物質の種類, $\beta$ 線 のエネルギーの大小江よって異をり，一概汇江 
いえないが, $\beta$ 放射能つ場合住電離己勵起作用 が最も重要を過程で，散亂がてれ沉次ぐ。制動

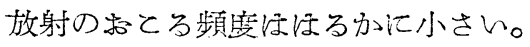

$\beta$ 粒子ほ物體の中でほ, 電離, 勵起散亂炎く

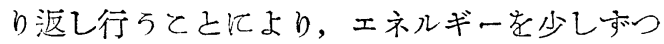
失々をがら，ジグザグに，乙かしをがら大體に 於て前方汇進む。

\section{2. $\gamma$ 線}

$\gamma$ 線忹同じェネルギーの腺とくらべて物質 を貫通する能力が滛かに大きい。

第 12 圖のよら䄈置で, 源から出を $\gamma$ 線の らち, 檢出器の方向に出たものだけが, てれに 大るよらにしておく。源と檢出器つ間江吸收體

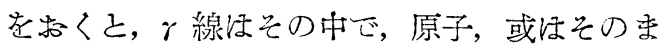
わりの電子己衝突して, 全エネルギ一を失って 消滅し, 或注エネルギーの一部を失って散亂さ れる。ての際と線方泆ったエネルギー住全部電 子炕與えられる。

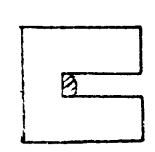

IIII

源

吸收体

第 12 圖 $r$ 線の吸收係數測定

圖の上らに源之檢出器の間隔が大きければ,

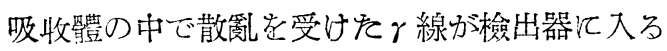

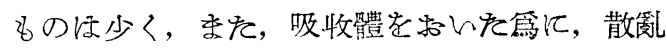
されて檢出器汇入るものも少い。てのようにし $\tau$, 吸收體门厚さ $x(\mathrm{~cm}$.) 专變えて, 檢出器に

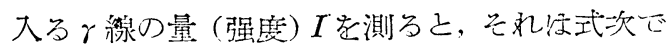
與えられる指數函數的江減少する。

$$
I=I_{o} e^{-\mu_{x} x}
$$

とれを第 13 圖江示す。 $\mu_{x}$ 以败收され易さを示 す量で, 線吸收係數 (linear absorption coefficient）という。吸收體の厚さを單位面績あた りの質量 $\left(g \mathrm{~cm} .^{-2}\right)$ 即ち（比重 $\left.\rho\right) \times x$ で表わ せば, 吸收曲線注, 線吸收係數つ代りに, 質量 挭收係數 $\mu_{n}=\mu_{x} / \rho$ 字用いて

$$
I=I_{o} e^{-\mu_{m}}{ }^{p x}
$$

と表わさ礼る。指數国數の性質としてて, 强度は, 吸收體つ厚さが $\left(0.693=\log _{\mathrm{e}} 2\right)$
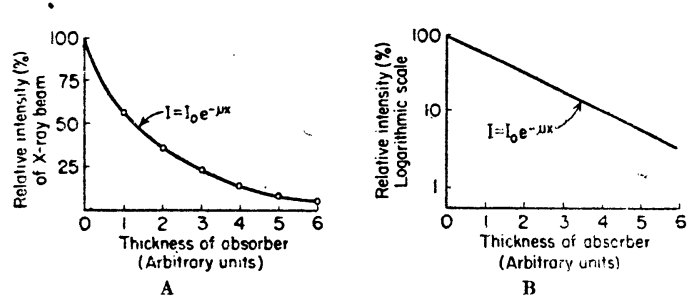

第13 圖 $r$ 線门吸收曲線

$$
X_{m}=0.633 / \mu_{m} \quad\left(g \mathrm{~cm} .{ }^{-2}\right)
$$

或注 $X=0.63 / \mu_{x} \quad(\mathrm{~cm}$.

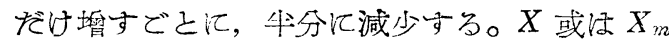
を牛值厚さ（half-value thickness）という。 吸收係數, 從って半值厚さ忹, $\gamma$ 線のエネルギ。 一 (波長), 吸收體つ物質汇上って買る。鉛飞つ いて, エネルギーと牛值厚さ之, エネルギーの 關係注第 14 圖の上5沉る。色爪物質汇つ いての吸收係數，半值厚さ走第 II 表沉かりげ る。同じェネルギーの及線の最大飛程とくらへ

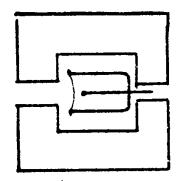

検出器
ていたがきたい。

實際の場合に注第 12 圖のよ ら理想的な幾何學的條件でな く，散亂された $\gamma$ 線の存在を考 慮汇入れなけ礼ばなら标いと 江注意要要する。

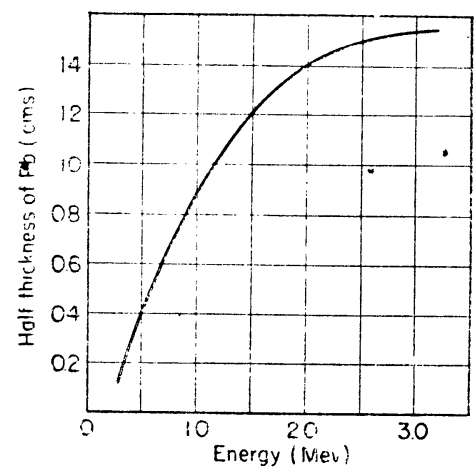

第14圖 鉛についての $\gamma$ 線の工 ネルギーと牛值㳵さの關係

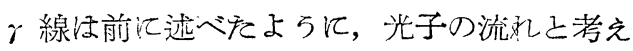
られる。光子が物質の中を通るとき起る過程の らち，主度るの次つ三つである。

(1) 光笔放果 (photo-electric effect) 光 
第 II 表 $\gamma$ 線の質量吸收係數と卅值厚さ

Characteristics of Common Shielding Materials

$\mu_{l}=$ linear absorption coefficient $=$ density $\times$ mass absorption crofficient

$x_{\frac{1}{2}}=$ half-thickness value for photons $=0.693 \div$ linear absorption coefficient

\begin{tabular}{|c|c|c|c|c|c|c|c|c|}
\hline Material & \multicolumn{2}{|c|}{ Water } & \multicolumn{2}{|c|}{ Aluminum } & \multicolumn{2}{|c|}{ Iron } & \multicolumn{2}{|c|}{ Lead } \\
\hline $\begin{array}{l}\text { Photon } \\
\text { Energy } \\
\text { (Mev) }\end{array}$ & $\begin{array}{c}\mu_{l} \\
\mathrm{~cm}^{-1}\end{array}$ & $\begin{array}{l}x \frac{3}{2} \\
\text { cm }\end{array}$ & $\begin{array}{c}\mu_{l} \\
\mathrm{~cm}^{-1}\end{array}$ & $\begin{array}{r}x_{\frac{1}{3}} \\
\mathrm{~cm}\end{array}$ & $\begin{array}{c}\mu l \\
\mathrm{~cm}^{-1}\end{array}$ & $\begin{array}{l}x_{\frac{1}{2}} \\
\mathrm{~cm}\end{array}$ & $\begin{array}{c}\mu_{l} \\
\mathrm{~cm}^{-1}\end{array}$ & $\begin{array}{l}x_{\frac{1}{2}} \\
\operatorname{cm}\end{array}$ \\
\hline 0.20 & 0.140 & 5.1 & 0.33 & 2.1 & 1.06 & 0.66 & 5.0 & 0.14 \\
\hline 0.50 & 0.090 & 7.8 & 0.23 & 3.0 & 0.63 & 1.11 & 1.7 & 0.40 \\
\hline 1.0 & $0.06 \%$ & 10.9 & 0.16 & 4.5 & 0.44 & 1.56 & 0.77 & 0.87 \\
\hline 1.5 & $0.05 \%$ & 12.0 & 0.14 & 5.1 & 0.40 & 1.74 & $0.5 \%$ & 1.9.5 \\
\hline Q.0 & 0.045 & 14.4 & 0.12 & 5.7 & 0.33 & 2.05 & 0.51 & 1.39 \\
\hline 9.5 & 0.012 & 16.5 & 0.10 & 8.9 & 0.31 & 2.22 & 0.43 & 1.47 \\
\hline 3.0 & 0.933 & 18.3 & 0.090 & 7.8 & 0.30 & 2.31 & 0.47 & 1.44 \\
\hline 4.0 & 0.033 & 91.0 & 0.082 & 8.4 & 0.27 & 2.55 & 0.48 & 1.47 \\
\hline 5.0 & 0.036 & 23.1 & 0.074 & 9.9 & 0.24 & 2.88 & 0.48 & 1.47 \\
\hline Substance & Water & $\begin{array}{c}\text { Alumi- } \\
\text { numi }\end{array}$ & $\begin{array}{l}\text { Lime- } \\
\text { stone }\end{array}$ & $\begin{array}{l}\text { Con- } \\
\text { erete }\end{array}$ & $\begin{array}{c}\mathrm{Ce}- \\
\text { ment }\end{array}$ & $\begin{array}{l}\text { Cast } \\
\text { Iron }\end{array}$ & Steel & Lead \\
\hline $\begin{array}{l}\text { Density } \\
(\mathrm{gm} / \mathrm{cc})\end{array}$ & 1.0 & 2.7 & $\begin{array}{l}2.7- \\
2.8\end{array}$ & 2.7 & $\begin{array}{l}2.7- \\
3.0\end{array}$ & 7.1 & 7.6 & 11.3 \\
\hline
\end{tabular}

子汪原子と衝突して軌道電子经全エネルギ

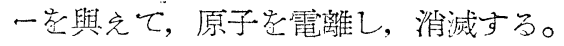

（2）コンプトン散亂 (Compton scattering) 光子以電子己衛突して, 振動數の異存万別 な光子となって散亂さ礼る。同時汇電子も 反動で運動エネルギー岀得る。

（3）骊子對創生（pair production） 光子 が原子核のそ壮苔通るさき，陰陽门電子の 對 (pair) t創り出し，自から注消隇する。 て礼は光子のエネルギーが， $1 \mathrm{MeV}$ 上り大 きいとを行の久起る。

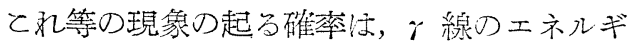
一の大小によって變化し，憵を物質の原子番號 によって異る。
光子经上汇述べたらに，物質の中で 1 囩の 過程で消滅するので，吸收體の中艺通るとさの 減少の有樣注，放射能の減表の場合の時間の代 りに，吸收體の厚さ索考えればよいわけで，光 子の數索 $I$, 吸收體の厚さ定 $x$ とすれば

$$
\Delta I=-\mu_{x} I \Delta x
$$

從って $I=I_{o} e^{-" \prime \prime} x^{x}$

亡枋分。

\section{3. $\gamma$ 線のレントゲン單位}

或る場所での $\gamma$ 線の量索袁方單位として, X線の場合のレントゲン單位を用いらことがあ, る。こ礼は標集條件の空氣中で 1 cc. 西たり 亿 1 静電單位のイオン(十或は一の一方沉ついて） 老作るような $と$ 線の量をんら。との定義加ら判。 
るよ5 と，て机活 $\gamma$ 線の强度（光子の數）を表 わするのではをい。線のエネルギーが異ると， 空氣の吸收係數が變わるので, その場所に於け ろ 線の强度が同一でも，レントゲン單位で測
った值活異る。この單位で $\gamma$ 線の量を測る汇は, 豫めての單位で目盛られた線量計 (dosimeter) によるのが簡便である。 


\section{第一日（8月 24 日）午後 \\ 放射線の測定（II）}

山崎文男

放射性物質加ら出る放射線を檢出し，測定す 万江當って役立つ方法汪, 多くの場合飞之れら の放射線が直接或的間接任原子又注分子者電 離する作用に基づんている。ウラニッムからの放 射線をべックレル注寡乾板によって檢出した が，て质も放射線の電離作用が浮劑中の銀化合 物孝化學處理に上って現像出來万狀態汇したの である。

この電離作用が氣體中で起ると，その氣體の 電氣傳導度が電離の度合比比例して壖加するか ら，ての電離を起している氣體の部分汇電界を 作用させれば，電離汇比例した電流がえられる。 て礼待文放射線の强度汇比例しているとと汇な ろ。

放射線の計數を行う種及の方法も, 多くの場 合に放射線の電離作用に基づいている。

一般に計數は，一つの電離作用をるった粒子 が氣體內它通過したとを江生じた篭離の胍動を 堆幅するてとによって行っている。ての粒子は 原子核から出を線のよらな一次放射線の場合

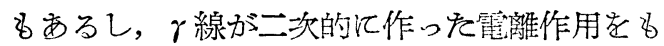

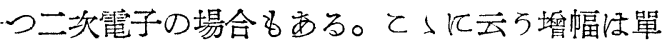
電子管国路のみによるとよも西るし，ガイガ 一・ミュラー計數管の場合の上う沉，管內の電離 しを氣體自身が主として行っている場合も亦 る。

ある種の結晶は放射線の作用で極めて短い時 間,微弱な光を出す。この現象をシンチレーショ ンと呼び, この光を增倍型光䉓管で增幅すると と汇よって放射線の計數を行らととが出來る。

今日わが國でラジオ・アイソトープを利用す ろ各方面で，放射線の檢出や測定主として用 いられているのは, ガイガー・ミュラー計數管 とローリッツェン檢電器で西り, ての他シンチレ ーション・カウンターも僅かながら用いられてい るから，て小ではそれらについて述べるてとに すろ。寫真乳劑につんては別に古關氏の講義が
西るのでこっではてれにふれない。

1. ローリッツェン檢電器 (Lauritsen electroscope)

放射線によって生じを電離電流の測定には一 般に極めて良好な絕緣體をるった高感度の電氣 測定器が必要である。

電雖電流を $i$ とすると,

$$
i=\Delta Q / \Delta t=C \Delta V / \Delta t
$$

であって， $Q$ 注電氣量， $V$ ほ $Q$ によ電氣容 量 $C$ 江生でを電位である。この式で明かなよ らに，C注出來るだけ小さくする必要が西る。

Lauritsen electroscope は原理的飞は古く から西る金䇴檢電器と同でで西るが，光机化比

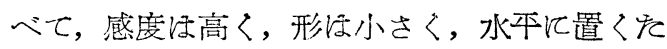
めの苦勞が少々等の秀れた點老持っている。

ての檢電器では凡そ $3 \mu$ のさの金メッキし

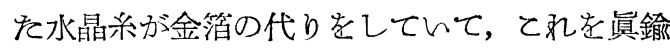
線に附した枝の部分飞眞鍮線之平行になるよう そつけて西る。德鍮線はアンブロイド等で作っ たよい絕緣物で支えられている。てれ荷電す ると水晶系江德鍮線之反撥乙西い，水晶系の彈 性の力と釣合った位置でとまる。

水晶系の先端にはて北之直角に，T字狀をな すよう沉同じ太さの水晶系の指針がつけて两 り，水晶系の先端の位置を讀夕とるに便利なよ らにしてある。

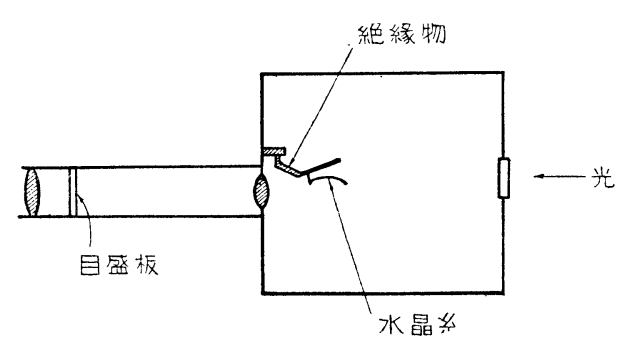

第 1 圖

第 1 圖に示しをように，ての檢電器は金屬製 の電離函の中化入ったり，倍率が凡そ50 倍 


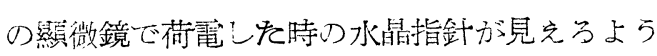
になっている。接眼鏡刀焦點面においた形子上 につけた目盛汇よって，指針の位置克讀む。

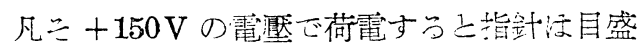

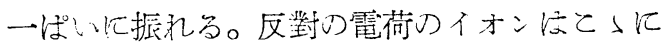

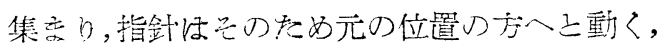
との動热の速さ度, 電離函中の? オンの發生に 比例几てている。

水晶系の先端の位置住，礼江與えられた電

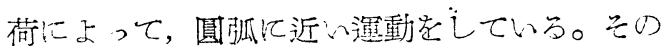
小部分论けの荤動索目盛上でみると, この動宾 は殆ざ集めら机をくオンの數汇比例している。 精密考測定安する至汇注，一定》目盛つ區間 について，指針の移動速度を測る可をである。

この檑の檢電器族射能つ强度老测定すると をには，單位時間に移動した指針の目盛でこれ 老表わす。例えば 10 目盛它動くのに，3分 24 秒老要しを度らば. $0.049 \mathrm{div}$./sec. 或い注 2.94 div./min.と分く。

Background 0.07 div./min. 位で㐫り, と れ注宇宙線, 周圍の建物等汇西方天然放射能: よるもの，電離函の壁圭作る物質中に極く僅か 含委礼ている天然放射性物質からり $\alpha$ 線汇上万 もの上䋓緣物孛通してつ電氣漏洩等汇基くるの である。

感度は $1 \mathrm{mg}$.のラジッム岂 $1 \mathrm{~m}$. 離して凡气 $3 \mathrm{div} / \mathrm{min}$.で西り，1 div。应凡气 $10^{6}$ イオン に相當している。

測定される放射線の强さが大さくなると, 電 離函中汇生ビをイオンの再結合のために，指針

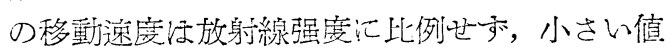
を示すよらになる。再結合惊イオンの數の自乘 に比例し, Lauritsen 檢霓器で注 1 div./sec. 程 度以上でほての影響が大きく現われる。

嘪際使用するに當っての注意を二・三のべて

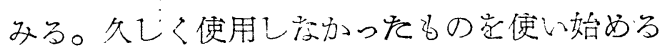
とき江, 絕緣物の子つ性質のために, 水晶禾 ほ著しく速く動く, 幾度か荷電して注, 放電さ 也る中に落ついを狀態沈る。連日使用してい

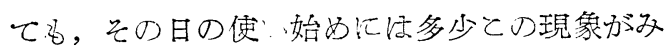
られるから，測定開始前质る心く早い時間汇荷 電しておくがよい。
水晶系は非常汇輕いから，函の內の空氣が動 く上てれ之共江動いて，指針の位置を正しく示

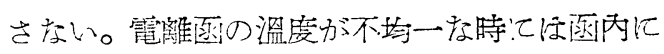
對流が起って上のてとが起ら。近くの電燈汅よ って一涌のみ分暖まるとを, 乾燥したての暖い

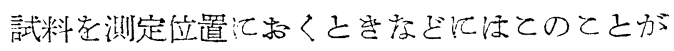
起乃から注意老要する。

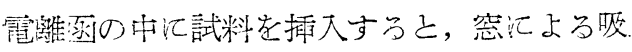

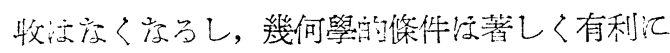

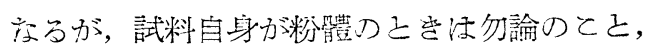

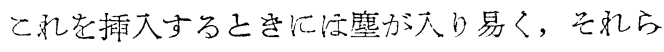
注荷電された水晶系江吸いつら就て附著し， 目盛板上飞この位置索讀みにく〉する。許す限 り試料法薄いアルミニッム簿で蔽らがよい。て の時にはに多少のピンホールがあっても差卖充 标。

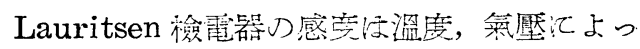
こ名僅か變化するから，㒸期汇亘方精密測定を 行う場合汇洨, ウラニッム, シジッムのような舞

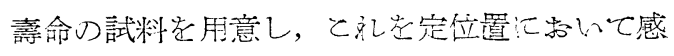
度つ輘正老するとよい。

\section{Geiger-Müller 計數管}

ガイガー・ミュラー計數管注現在放射性同位 元素を利用している人ふ汇よって，最子多く用 いられている測定器で市る。單にガイガー計數 管と呼ばれるとをも西り，又略して G-M 計數 管ともい5。

構造注測定つ目的化應じて種ふの形狀, 材料 のつのが西方分，圓筒狀の陰極亡，关の軸飞沿

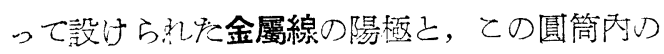

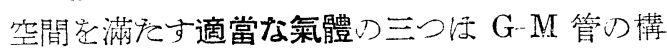
成琶萃で㐫る。

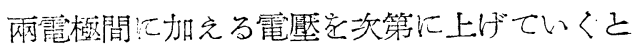

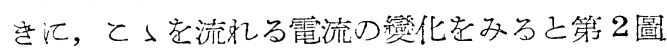
のよら䄈え。

電踓作用安もつ粒子小通瀜㲹よって生じたイ オン對は分礼て，丽極一之移動するが，加えら

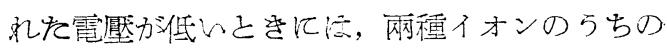

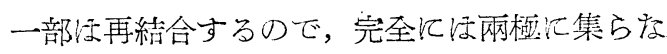

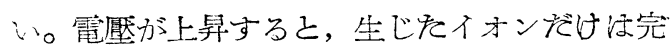

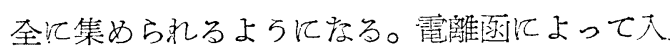

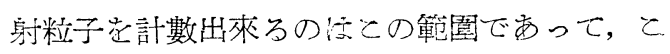




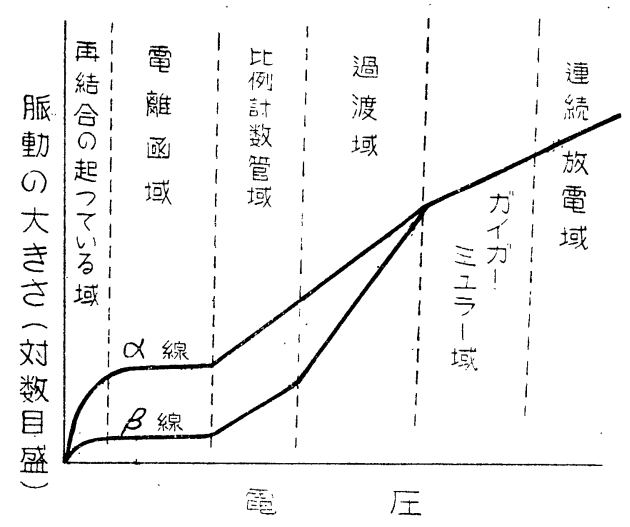

第 2 圖

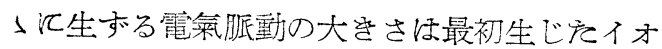
ン對の數に比例している。 $\alpha$ 粒子深その過ぎた 後に濃いイオン對を殘すから, 再結合が起り易 く, 電離函の範圍化大る汇要す万電厴注，宇宙 線や速い電子の場合上り高い。

更注電壓老上げると，イオン對の一方で市る 電子注中心線の近くの强哃瞍のため汇速度が 大きくなり，そてに西る氣體分子䉓離できる ようになる。の新しく生じた琵子注更汇衝突

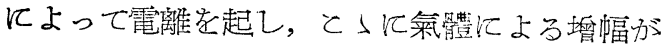
生じ，流れる電氣は一定の割合だけ大をな量之 なる。電壓を一定经っておけば，最初生じを イオン對の數に比例した電莱胍動がえられる。

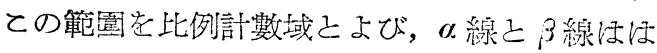
っきり區別出來る。

電㻺者更に上げると，ての比例緊係が嚴密に

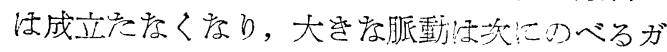

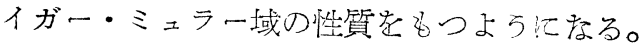

次にくるのがガイガー・ミュラー域で㐫って， てっで注粒子の大射炕よって最初生じをイオン 對の數の如何に係少ら方，一定の大管さの電氣 脈動が生辛る。ての域注電壓に無關係に一定の 計數が行和る。

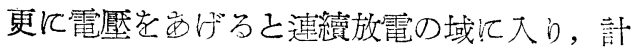
數が不可能上后る。

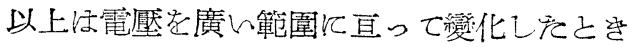
に起る電氣脈動の大きさを述べをが，この中に あるガイガー・ミェラー域で働かせるのが，ガ イガー・ミュラー計數管である。
ガイガー・ミュラー計數管は中汇封じた氣體 によって2種汇分つてとができる。その一注水 素, アルゴン等の 2 原子或いは單原子氣體のみ を用いたもので，ての種の計數管では放電が管 內にイオン對が發生したてとによって引き起さ れる之，陽極電壓が何らかの方法で下げられな い限り，放電注引ほ續いて起り計數の目的家達 するととが出來ない。ての方法として仿，管外 で陽極汇 $10^{9}$ オーム程度の抵抗を入れるか, 電 子管司路の助けによって，管內に生じを陽イオ ンが完全に除極㙫められるまでの間，陽極が ガイガー・ミュラー放電老起すととの出來ない低 い電壓保保っておくので亦る。電子回路の場合 には 1,000 分の数秒の分解時間, 郎ち引續い て入射した粒子を二つとして計數出來る最少時 間とするととが出來るが，高抵抗のときには， 1/100 秒の程度にさえなり, 高度の計數が出 來ない。ての種のものを外部渻滅 (external quenching) 型計數管或话.slow counter 之云 5 。

所がアルゴン，ヘリッム等にアルコール，エ ーテル，エチレンのような多原子の氣體它加え る己，放電が一つでさまるようになり，ての種 のもの自己消滅型（self-quenching）或い就 fast counter 之呼ぶ。分解時間忟 $10^{-4}$ 秒の程 度で西る。

現在多く使用されているの礼自己消滅型であ る。

次に實際儿放射線測定江際して必要な G-M 計數管の特性につんてのべる。

\section{（1）計數率對電壓特性}

一定の平均强度の放射線汇對乙て示す。加元 られた電壓と計數率（單位時間の計數）の關係 ほ第3圖に示したよらになる。

計數管に加える電壓がC在とすと計數它始め るので, ての點荍始動電厴 (Starting voltage) と云う。更に電壓をあげるとAに達しててっで 始めてガイガー・ミュラー域化大る。との電壓 老開始電壓 (Threshold voltage) とよぶ。

てかからBと至る範圍をプラトー (Plateau) とよび，との間では計數率は加えら玌た電壓に

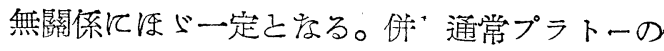




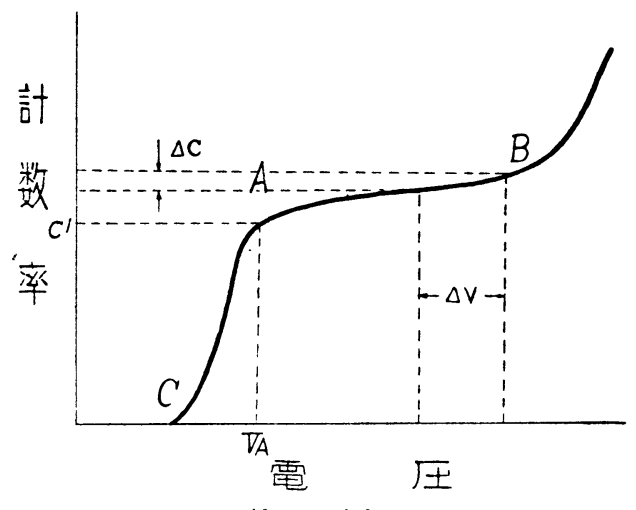

第 3 圖

長さ $\mathrm{AB}$ 泟僅かの傾きをるち, 電壓が $100 \mathrm{~V}$ 上 ったとき，計數率が $\mathrm{C}$ から $\mathrm{C}+\Delta \mathrm{C}$ 飞倍加すれ ば，傾斜 (Slope) が $100 \mathrm{~V}$ 當り $100 \cdot \frac{\Delta \mathrm{C}}{\mathrm{C}}$ であると云わ礼る。

このプラトーの長さと傾斜とは計數管の良否 を定わる一つの目安となる。併し傾斜をての 100V 當りにとると，低電壓で衝く計數管で ほ大きな值となり易く， Normalzed plateau slope を用いる方がよい。て礼は第 圖に示し を特性曲線で, 傾斜 $\Delta \mathrm{C} / \Delta V$ 老 threshold $\mathrm{A}$ 飞 於ける計數率 $\mathrm{C}^{\prime}$ と電壓 $V_{A}$ の比で除した商, 郎ち $\frac{\Delta \mathrm{C} / \Delta V}{\mathrm{C}^{\prime} / V_{A}}$ で定義した值である。

計數管ひBをてえて更に電壓を上げると，計 數率注急に增加し, 連續放電の域に入るから, ての特性曲線を測定するときては注意してての 域に大らぬよらにする。ての域で放電をさせる 之計數管は特性が忽ち劣化する。

管に加えられた電壓と開始電壓 $V_{A}$ との差を 超過電壓 (Overvoltage) とよぶ。

通常, ガイガー・ミュラー計數管を使用する そきにほ，變動の少い安定化した電壓を管に加 えるが，その電壓の值は超過電壓がプラトーの 25\%位が適當で㐫る。

ガイガー・ミュラー計數管の出力を增幅し， 計數の開始によって棤軸が 1 回だけ振るように したオッシロスコープによって，との電氣脈動 の形をみる之第 4 圖の樣を圖形をみる。

計數率が少い間注左に示した脈動のみしか現 ふ秃致いが，計數率を增加すると右にみえるよ ろな, 脈動の群が出てくる。てれは左の放射に
引き續いて生じを放電を示している。てれから 制る上ら沉ガイガー・ミュラー計數管で注一つ の計數の後沉は, 計數の出來ない一定つ時間が あり，と㞦を不感時間 (Dead time) と上ぶ。 この後江管內に生じを電離恬最初は小さく，時 間之共汇次第江大をな放電を引き起すようにな り，逐汇最初のるのと同じ大をさを示すように なる。との時間を回復時間 (Recovery time) とよぶ。計數管に附した司路によって，ぞの大 きさのものから計數が可能となるか忹定るの で,一つの計數後に次の計數が始めて可能にな るまでの時間を分解時間 (Resolving time) と よんでんる。

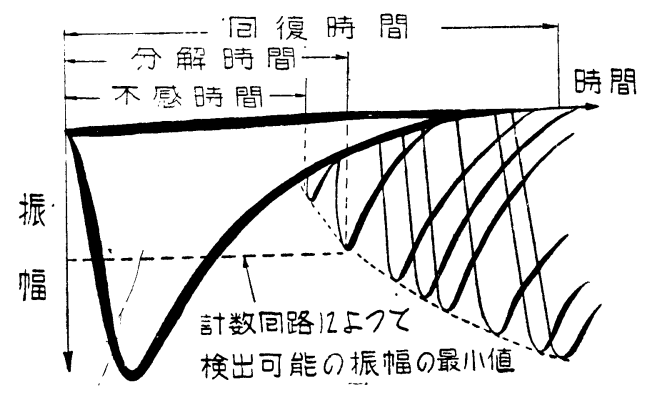

第 4 圖

さきにガイガー・ミュラー計數管でほ入射粒 子の作ったイオン對の後無關係に一定の大き さの一つの放電を起すと述べたが，と礼は回復 時間以上の距りをるった場合のてとで，計數率

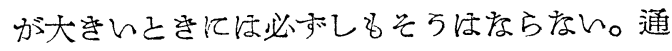
常のガイガー・ミュラー計數管裝置でほての分 解時間は $10^{-4}$ 秒の程度である。

ガイガー・ミュラー計數管で放射線强度を測 定するとをには，電子管包路による計數率計を 用いるか，個々の放電胍動を記錄して任意の時 間內にきた總數を錄數する回路を用いる。少い 計數率の場合にほ前者ほ適さない。

電氣的の力で機械的に錄數する器械はこの目 的に用いられるが，可動部分の慣性飞よって單 位時間江可能な錄數任制限される。通常ての值 は每秒 10〜50 位で西る。の制限にらちかつ ために注，錄數器は全體の計數つ西分數のみ を記錄する司路が用いられる。てのために現在 多く用いられているのは，2進法间路をもとに 
しをるので，てれを組合せて 8 進，16 進等 $2^{n}$ 進法がでを，更に近頃はてれを適當に組合せて 10 進法 100 淮法が用いられるようになってい る。これらの場合に，錄數器の記錄以下の端數 通常は小型のネオンランプの點燈によって讀み とられる。

現在使用されている計數包路の分解時間はガ イガー・ミュラー計數管のそれに比べて遙かに 短いから， scaling ratio を適當汇選べ，た 之元錄數器の分解時間が上記の上うに長くても 何等數えおとしをしないよらにできる。

從っててのよらな計數裝置を用いたときに 注, 高度の計數率に際しての數え落し注計數管 に基くもののみとなる。計數管の分解時間を て とし, 真の計數率孝 $N$ ，記錄された計數率を $n$ とすると，

$$
n=\begin{gathered}
N \\
1+\tau N
\end{gathered}
$$

或汪 $N=\frac{n}{1-\tau n}$ となる。

計數管の分解時間 $\tau$ の決め方には，種及の方 法があるが, 最子直接的なのふォッシロスコー プ汇よって測定である。

併し通常次の方法を用いる。二つの放射線源 を作り，先ずその一つで計數率 $n_{1}$ 索測り，次 飞他を加えて $n_{12}$ を，次海最初の除んて $n_{2}$ を測る。

てのとを兩試料は互いに干涉して他の計數に 影響を與えないようにおく。

別飞 background $n_{b}$ 专測っておく。てれた 行の測定值加ら, 分解時間 $\tau$ 注

$$
\tau=\frac{n_{1}+n_{2}-n_{12}-n_{b}}{n_{12}{ }^{2}-n_{1}^{2}-n_{2}^{2}}
$$

で與えられる。通常 $n_{1}, n_{2}$ ほ每分 1,000 位の 当のが用いられる。ての式から明かな上机分 子は小さい數となるから， $n_{1}, n_{2}$ 及び $n_{3}$ に充 分精密測って㤁く。

3. シンチレーションカウンター (Scintillation counter)

或る種の結晶は $\alpha$ 粒子， $\beta$ 粒子がての中を通 るとをに微かを光を放つ。との光を近年急速に
發達した增倍型光電管 (Multiplier phototube 或任 Photomultiplier) で檢出するのが Scintillation counter である。

光を放つ物質を䖝光體 (phosphor) とよび， 結晶に限ら方液體子㐫る。ラジオ・アイソトー プの利用方面では, 主として は測定用として，Tl で活化した NaI の結晶が 用いられる。

同じ體績で，G-M 計數管に比へてて $\gamma$ 線に對 する感度が高いてと, 分解時間が $10^{-7}$ 秒程度に 下げられをてと等の特長をるつので, 測定可能 の强度の範圍が著しく大きい。

現在, 能率の高い增倍型光電管の國產品がな レとと〉, 螢光體も市販してないから共に輸入 するより他ないので，わが國で学の使用がお くれている。

\section{$\beta$ 線の測定}

乃線年電離作用をるつから, Lauritsen electroscope でる， G-M 計數管でも測定出來る。 現在實驗室で測定を必要とする程度の强さの $\beta$ 線測定にほ薄い空をるった G-M 計數管が最も 上く用いられている。その例安第 5 圖に示す。

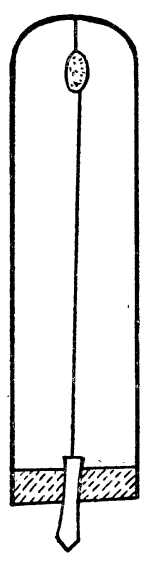

第 5 圖

左のは End window 型で, 薄い雲母の空W が管の一端に西り，一端に硝子の小球をつけた 
中心線はての窓の近くに終っている。ての種の

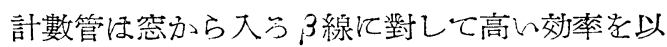
て測定できる。

右にあるの活凡と $0.31 \mathrm{Mev}$ 以上りエネルギ

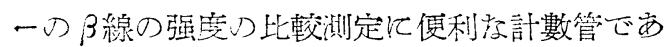

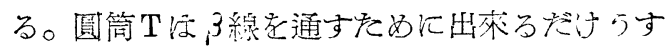
いと上が望委机らが，中汇ガス总つめ万とをに

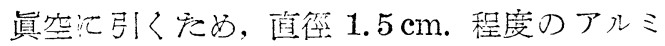

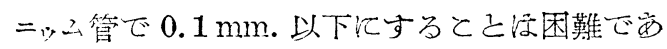
る。この厚さで法 $0.35 \mathrm{Mev}$ 以下つ $\beta$ 線汪全部 吸收されて測定出來ない。同樣つものが銀づけ しを硝子でも作ら犯ら。

\section{End window 型計數管による $\beta$ の測定}

薄い雲母空をるつ計數管で信赖出來万比較測

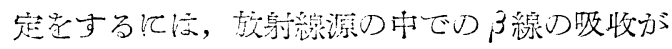

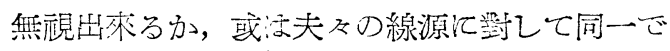

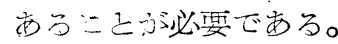

線源中の $\beta$ 線の呚收汇路して $2 \%$ 以㐫の補正

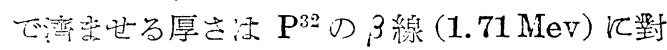

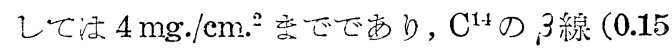
$\mathrm{Mev}$ ）に對して度せいぜい $0.16 \mathrm{mg} . / \mathrm{cm}^{2}$.

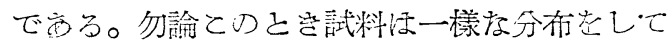
、庆け机ば学ら原い。

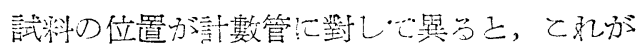

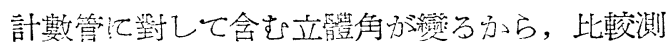

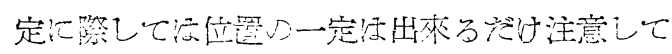

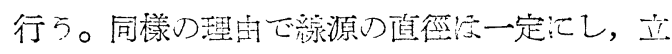

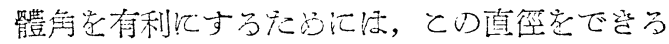
だす小さくする。

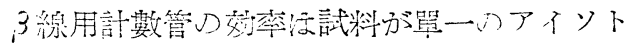

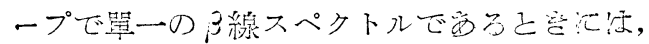

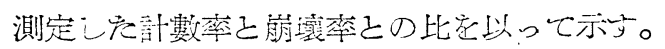

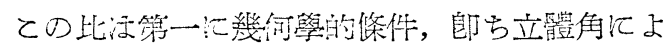

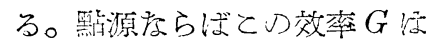

$$
G=0.5(1-\cos \theta)
$$

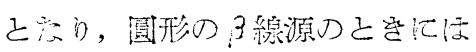

$$
G=0.5\left(1-\frac{1}{(1+\beta)^{1}}-\frac{3}{8} \frac{\beta}{(1+?)^{52}}\right)
$$

但し $\beta=\frac{b^{2}}{a^{2}}, \gamma=\frac{c^{2}}{a^{2}}$ で $\beta$ が $1 / 20$ より小さ 蚁比よ合う。
次に線のエネルギーによって效率ほ變化す

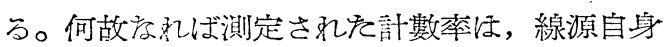
の中, 線源と空との間の空蒌及び窓の中での吸 收によるからで西る。更に計數率は散亂によっ て影響される。最初に注計數管へ向ってい壳か った $\beta$ 線が散销によって大ってくるてとが两 り，試料自身汇上るもの之，試料古の也をるの

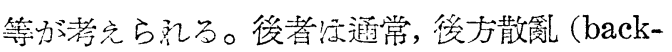
scattering）之呼ばれている。

試料自身中での败收注自己吸收 (Selfabsorption）己呼汸礼る。一定の specific activityの 試料死同一心廣さに，種及異っ表厚さとして一 定り位置で測うと，它厚さに至らと飽和值に 涬する。とつ值仗 infinite thickness の activity とよばれる。（第6 6 圖）

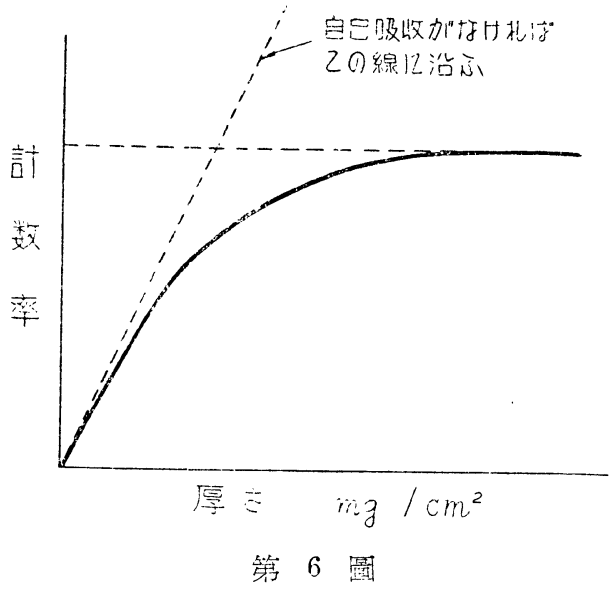

測定汇供する試料:こついてとの關係を圖示し て岕いて補正するの汸よいが，并の試料中での 今線の吸收係數が制ってお秃ば次の式で補正が だる。

$$
I / I_{0}=\left(1-e^{-\mu d}\right) / \mu d
$$

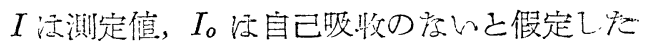
之きの值, $\mu$ 注吸收係數 $\left(\mathrm{cm} .{ }^{2} / \mathrm{mg}\right.$. 單位) $d$ 注 試量つ厚さ $\left(\mathrm{mg} . / \mathrm{cm} .^{2}\right)$ ごある。

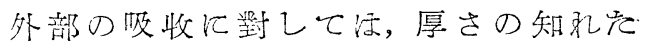
$\left(\mathrm{mg} . / \mathrm{cm} .{ }^{2}\right.$ 箅位で) アルミニッ板老吸收物とし

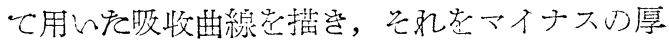
さのf向に，雲母窓と空氣の和だけの厚さまで 超長して，乙秃起救的る。(第 7 圖） 


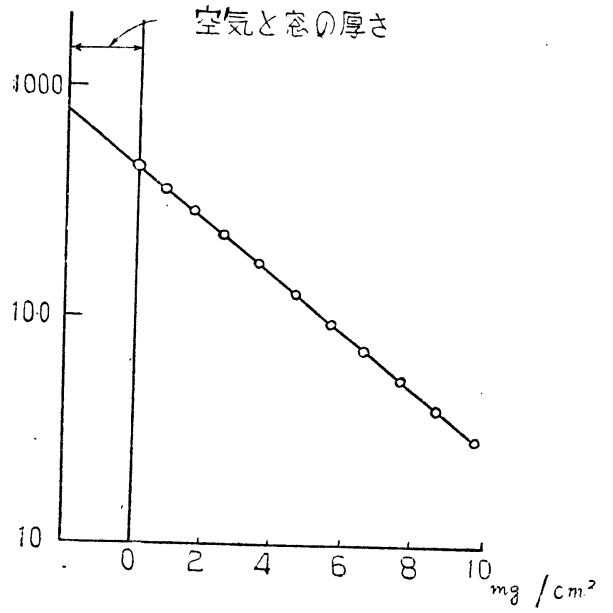

第 7 圆

異った最大エネルギーの及線については夫及 この值を定める。

Backscattering の影辠汪試料支持物を原子 番號が低い物質で，然も气の厚さの溥いものを 用いるととによって少くする，厚さ zero の值 䇇必要を之きには，支持物之同一物質の種々の

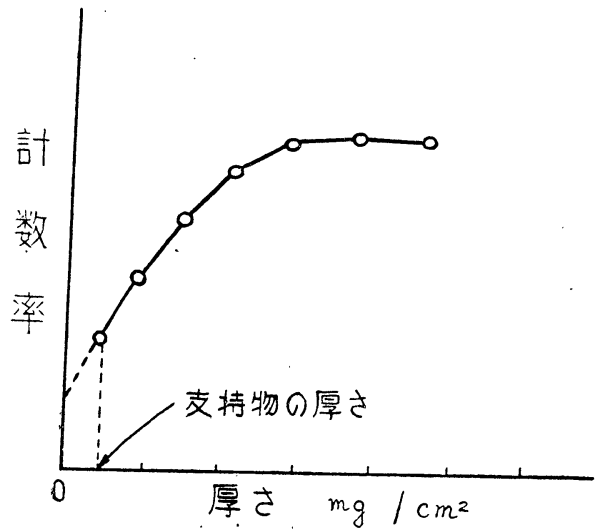

第 8 藓
厚さの層老重悋て, その都度測定して得そ值を 圖示して求める。（第 8 圖）

比較測定の場合に注 back scattering の飽和 值洼した厚さのもの学用いるのがよん。微弱 放射能の測定には原子番號の高い物質学支持 物質とする己計數がいくらか樂江をる。但し鉛 飞注自然放射性物質を含んでいるてとがあるか ら注意を要する。

\section{$\gamma$ 線の 測 定}

G-M 計數管によって $\gamma$ 線老測定するとき沉 は管壁材料が高い原子番號のるの」方が，一般 に能率がよんとされている。 によってての效率は變るが，一般に 線のエネ ルギーが $1 \mathrm{Mev}$ から $2 \mathrm{Mev}$ の間で注 $1 \%$ 前後 とみてよん。

$\gamma$ 線は一般江透過力が大きいから, 線源自身 の吸收忹少的。從って豫め G-M 計數管孝强さ の知肌たラジオ・アイソトープについでの效 率を調へて志くと，その後はそのアイソトープ の未知の强さを定めるのに便利である。

レントゲン單位は空氣と云う特定を物筫中で の と線吸・牧量であるから，壁が空氣に近い原子 番號の物質でできを篭離函を用いるととによっ てレントゲン量老はかるてとがでさる。

ベークライトル炭素をらすく好った壁のるの がよく用いられる。

シンチレーション・カウンターで炡, phosphor 中で吸收された 線光光出すから，るしその 光汇對して境倍型光電管が完全に對應した脈動 老起せば，計數效率は非常沉高的。光老光電面 にいかに能率よく導くかによって，能率が變 る。胍動の大きさの分布をは好てとによっ て，そのケ線のエネルギーが测れること壮 G-M 管に比べて有利な點である。 
放射性同位元素の臨床醫學上の應用

慶大醫學部 助呚授少下 久雄

はしがき

1. アイソトープ内用の一般的注意事項

2. 體内攝取アイソトープの放射線量の測定

3. 安全追跡子濃度

4. 診斷上への應用
（1）循環血漿並びに血球量の測定
(2) 循環時間の測定
（3）消化管の吸收亚びに排泄
（4）細胞外液量の測定
(5) 甲狀腺機能檢查
(6) 初血の診斷
（7）皮局及び粘膜の吸收と排泄
(8) 荟髓液の檢查

\section{はしがき}

アイソトープの應用は實に廣く, 醫學上の應 用丈で方追跡子實驗を入れると奎く多岐に亘る ものである。そのちち, 人體に直接投與して診 斷亚びに治療に應用する場合文に就いて，略述 する。 $\mathrm{Co}^{60}$ の如く $\mathrm{Ra}$ と全く同じように使用

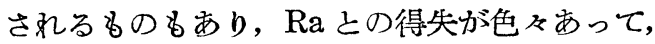
利用價值が廣くなって來た。气の他の多くは內 服とか注射とかによって直接人體內に取入れる ので，その投與量や投與法なぼに就いて特别の 注意が必要である。それで, 先ず一般的の注意 事項を述へ，それから診断上並びに治療上への 應用の主なるのを擧げよう。

\section{I・アイソトープ內用の一般的注靑事項}

アイソトープを人體內に投與する際には次の 事項を守ることが望ましい。

(1) アイソトープの壽命

郎ち, 牛減期が餘り長からず, 又短からざる ことが望ましい。牛減期が 30 日あるとすると 10\%に減亦るのに 4 ,月を要し, それ文長期に 亘って作用するのであるから，後述する作用線
炎)
（9）腫痬の診断

(10) 藥物の作用

5. 治療上への應用
（1）バセドー氏病
(2) 㑯性多血症
(3) 白血病
(4) 惡性䭪愓

6. ラジゥム代用としてのアイソトープ
（1）大量遠距離照射
(2) 管と針
(3) 線とセル
（4） $\beta$ 線による外面照射療法 むすび

量を考え, 使用量を調笁せ小ばをらない。又と のアイソトープの壽命注短くとも, それに混っ ているものに壽命の長いものがあると危險であ う。例えば $\mathrm{Mn}^{52}\left(\mathrm{~T}=6.5\right.$ 日) に注約 $1 \% \mathrm{Mn}^{5.1}$ （T=310日）が混じているが如きてとがある。 文. $\mathrm{Mn}^{59}$ ( $\mathrm{T}=67$ 時) 老使用す万之，そ饥が壞變 して $\mathrm{Tc}^{99}\left(\mathrm{~T}=\mathbf{5} \times 10^{5}\right.$ 年) を生じ，それが壽命 が長くて危險教合も京る。他方亦, 牛減期が 短かすぎると矢張り都合が惡い。簡單に早速入 手出來る歐米でも, 牛減期が12時間以上である ことが望ましんと云っている。從って, 壽命の 點からは牛減期が12時間から15日位のものが最 多優れていることになる。

（2）アイソトープの化學的性質

化學的性質がよく分っていて, 生體に對する 毒性の有無子分っていなければならない。毒性 は叉, 量的の問題にも關係する るので, 例えば, ${ }_{39} \mathrm{Y}^{89}+{ }_{0} \mathrm{n}^{1} \rightarrow{ }_{39} \mathrm{Y}^{90}+\mathrm{hv}$ で出來た $\mathrm{Y}$ は比放射能 が低んので, 多量の $\mathrm{Y}$ を投與せねばをらず, 診断上の應用でも危險であるが， ${ }_{22} U^{235}$ の分離 產物の ${ }_{38} \mathrm{Sr}^{90}$ が ${ }_{38} \mathrm{Sr}^{90} \rightarrow{ }_{39} \mathrm{Y}^{90}+\mathrm{e}^{-}$の $\beta$ 崩壞 ( $\mathrm{T}=25$ 年) で出來たものをイオン交換樹脂など 
で分離して得た $\mathrm{Y}^{90}$ は純粹であって，極微量 投與で濟むから無毒となし得る。

（3）生體內に於げ万分布之排泄

生體內で如何に分布するかを知り，之の目的 に適合したアイソトープを撰ばねばならない。 師ち目的とする贜器や細胞など丈に攝取される ものが望ましい。色ふの贜器に入るとしてると の攝取率を知り，排泄狀態分分り，生體內江殘 る率郎ち生物學的牛減期(Biological half life) を知らねばをらない。それによって，本當汇各 臟器に作用する放射線量が計算出來る。

（4）放射線の種類之性質

使用するアイソトープの放射線の種類とその エネルギーその他の性質を知り，人體或は各臟 器に作用する線量を計測せねばをらない。その 算出方法は次項で述へる。

\section{II・體內攝取アイソトープの放射線量の測量}

$\mathrm{X}$ 線や $\gamma$ 線の線量は $\mathbf{r}$ 單位 (roentgen) で 表わすここが出來るが，アイソトープのエネル ギーの重要部分である $\beta$ 線には通用しない。 $1 \mathrm{r}$ 量は空氣 $1 \mathrm{~g}$. 中で吸收されるエネルギーが 83 ergであるので，そのエネルギー量で $\beta$ 線の單 位とすることが出來る。Evans, Marinelli 等(1) は Equivalent roentgen (er) と云い, Plutoneum Project(2) では Roentgen equivalent physical (rep) と名付け, 最近は rep が廣く 用いられるよらとをった。 Mayneord 注空中の みならず, 組織 1g. 中で消費される放射線の線 量を gram-roentgen 己呼んだ。軟部組織だと 空中と大差ないが, 骨等だと相當の差があり, 叉 放射線のエネルギーによっても異る。 Parker の最近の研究によると, 人體組織汇就いては

1 gram-roentgen $=1$ rep $=93 \mathrm{ergs} / \mathrm{g}$. tissue

であるとんう。

(1) $\beta$ 線量の計測

$\beta$ 線を放射するアイソトープが組織內と攝取 されている時は，その飛程は數 $\mathrm{mm}$. 以下で西 るから，大體その部位文に局限して作用すると
考えられる。組織 1g. 中のアイソトープ量を $C$ $\mu \mathrm{c}$, 毎秒の崩壞數孝 $n, \beta$ 線の平均エネルギー を $\bar{E}_{\beta}(\mathrm{Mev})$, 組織中吸收されるエネルギー 量を $\mathrm{D}_{\beta}(\mathrm{ev})$ とすると，

$$
\begin{aligned}
D_{\beta} & =n \bar{E}_{\beta} \times 10^{6}(\mathrm{ev}) \\
& =3.7 \times 10^{1} \mathrm{C} \times \bar{E}_{\beta} \times 10^{6}=3.7 \times 10^{10} \mathrm{C} E_{\beta}(\mathrm{ev})
\end{aligned}
$$

である。1 rep の際 1g. 中住生すイオン數注 $1.62 \times 10^{12}$ で，1イオン對を生ずるエネルギー は $32.5 \mathrm{ev}$ であるので，

$$
\begin{aligned}
D_{\beta} & =\frac{3.7 \times 10^{10} C \bar{E}_{\beta}}{1.62 \times 10^{12} \times 32.5}=\frac{3.7 \times 10^{10} C \bar{E}_{\beta}}{5.24 \times 10^{13}} \\
& =7.1 \times 10^{-4} C E_{\beta}(\mathrm{rep} / \mathrm{sec} .) \ldots \ldots \ldots \ldots(3)
\end{aligned}
$$

で, 組織中のアイソトープ量とその $\beta$ 線の平均 エネルギーが分れば,毎秒の放射線量が分る。ア イソトープの本減期を $T^{(\text {日) }}$ とする之， そのア イソトープが全部崩壤して了らまでに與えられ る放射線量 $\left(\bar{D}_{\beta}=\mu \mathrm{c} d\right)$ は

$$
\begin{aligned}
\bar{D}_{\beta} & =7.1 \times 10^{-4} C E \times \frac{60 \times 60 \times 24 T}{0.693} \\
& =88 E_{\beta} T C=K_{\beta} C \text { (rep) } \ldots \ldots \ldots \ldots
\end{aligned}
$$

となる。 $K_{\beta}$ は $1 \mu \mathrm{c} d / \mathrm{g}$. tissue の線量で, 主 なアイソトープに就いてのるのは第1表(次面) に示す通りである。

身體に本等に分布する場合は上式でよいが， 組織によって吸收率の異る場合は, その臟器組 織の濃度を平均濃度で割った值, 䬦ち吸收率較 差 (Differential absorption ratio, D. A. R.) を乘するとアイソトープ量が分り，放射線量を 算出出來る。

陽電子放射體では，同時飞陽電子消減線 (Annihilation rays）孝放射する。それは 0.511 $\mathrm{Mev}$ の $\gamma$ 線エネルギーに相當するので次項で 述べる $\gamma$ 線放射の計算を加味せねばをらない。

(2) $\gamma$ 線量の計測

體外での $\gamma$ 線や $\mathrm{X}$ 線の測定に, 組織內での 散樀之吸收之を計算飞入れて組織內線量を算出 すればよいが，到達距離が大きいので複雜であ る。そこで餘り遠方からのものが作用しないと 假定すると, 織組 $1 \mathrm{~g}$. 內 $C$ 亿

(1) Evans: Am. J. Roent., 58 (1947), 754.

(2) PARKER: Radiology, 54 (1950), 257. 
第I表 $\beta$ 線線量の物理的計測値 (Marine, $i$ 等 (3),(4))

\begin{tabular}{|c|c|c|c|c|c|c|c|c|c|c|}
\hline Element & $Z$ & $A$ & Radiation & $\begin{array}{l}T \\
\text { Half life } \\
\text { in days }\end{array}$ & $\underset{\text { (Mev) }}{\bar{E}_{\beta}}$ & $\begin{array}{l}K_{\beta} \\
\text { e.r.f } \mu \mathrm{cd} \\
\text { per } \mathrm{gram}\end{array}$ & $\begin{array}{c}f_{d} \\
\text { fraction } \\
\text { Cisintegr. } \\
\text { per day }\end{array}$ & $\stackrel{S_{\mathcal{\beta}}}{\mu<\mathrm{ker}} \mathrm{kg}$ & $\begin{array}{l}\text { Weight } \\
\text { per mc in } \\
\text { ro-9 grain }\end{array}$ & $\begin{array}{l}\text { Maximum } \\
\text { range in } \\
\text { water } \\
(\mathrm{mm})\end{array}$ \\
\hline \multicolumn{10}{|c|}{ Group $A: \bar{E}_{\beta}$ is known to an accuracy of a few per cent } & . \\
\hline $\begin{array}{l}\mathrm{C} \\
\mathrm{N} \\
\mathrm{Na} \\
\mathrm{P} \\
\mathrm{Cl} \\
\mathrm{K} \\
\mathrm{Sc} \\
\mathrm{Mn} \\
\mathrm{Fe} \\
\mathrm{Co} \\
\mathrm{Cu} \\
\mathrm{Zn} \\
\mathrm{As} \\
\mathrm{Br} \\
\mathrm{In} \\
\mathrm{l} \\
\mathrm{RaE}\end{array}$ & $\begin{array}{r}6 \\
7 \\
11 \\
15 \\
17 \\
19 \\
21 \\
23 \\
25 \\
26 \\
27 \\
29 \\
30 \\
33 \\
35 \\
49 \\
53 \\
83 \\
\end{array}$ & $\begin{array}{l}11 \\
13 \\
22 \\
24 \\
32 \\
38 \\
42 \\
46 \\
4 S \\
52 \\
56 \\
50 \\
55 \\
60 \\
61 \\
64 \\
63 \\
76 \\
52 \\
112 \\
130 \\
131 \\
210 \\
\end{array}$ & $\begin{array}{l}\beta_{+}^{+}, 0 \\
\beta^{+}, 0 \\
\beta^{+}, \gamma \\
\beta^{-}, \gamma \\
\beta^{-}, 0 \\
\beta^{-}, \gamma \\
\beta^{-}, \gamma \\
\beta^{-}, \gamma \\
\beta^{+}, K, \gamma \\
\beta^{+}, K, \gamma \\
\beta^{-}, \gamma \\
\beta^{-}, \gamma \\
\beta^{+}, \gamma \\
\beta^{-}, \gamma \\
\beta^{+}, K, 0 \\
\beta^{+}, \mathcal{K}, K, 0 \\
\sigma^{+}, K, \gamma \\
\mathcal{B}^{-}, \gamma \\
\beta^{-}, \gamma \\
\beta^{-},(\gamma) \\
\beta^{-}, \gamma \\
\beta^{-}, \gamma \\
\beta^{-}, 0 \\
\end{array}$ & $\begin{array}{c}0.014 \\
0.007 \\
1100 \\
0.61 \\
14.5 \\
0.026 \\
0.515 \\
85 \\
16 \\
6.5 \\
0.108 \\
47 \\
85 \\
1940 \\
0.14^{2} \\
0.53 \\
0.027 \\
1.12 \\
1.5 \\
50 \\
0.525 \\
8.0 \\
4.85 \\
\end{array}$ & $\begin{array}{l}0.380 \\
0.475 \\
0.225 \\
0.540 \\
0.695 \\
1.390 \\
1.395 \\
1.117 \\
0.175 \\
0.085 \\
0.890 \\
0.120 \\
0.655 \\
0.009 \\
0.433 \\
0.120 \\
0.965 \\
1.170 \\
0.150 \\
0.940 \\
0.270 \\
0.205 \\
0.330 \\
\end{array}$ & $\begin{array}{c}0.47 \\
0.29 \\
22000 \\
29 \\
885 \\
3.2 \\
63 \\
870 \\
245 \\
48 \\
8.5 \\
406 \\
4900 \\
17000 \\
5.4 \\
5.6 \\
2.3 \\
115 \\
20 \\
4150 \\
12.4 \\
144 \\
141 \\
\end{array}$ & $\begin{array}{l}1.0 \\
1.0 \\
6.3 \cdot 10^{-4} \\
0.68 \\
0.0 .47 \\
1.0 \\
0.74 \\
0.008 \\
0.042 \\
0.101 \\
0.998 \\
0.015 \\
0.008 \\
3.6 \cdot 10^{-4} \\
0.992 \\
0.73 \\
1.0 \\
0.46 \\
0.37 \\
0.014 \\
0.73 \\
0.083 \\
0.133 \\
\end{array}$ & $\begin{array}{r}213 \\
345 \\
7.3 \\
5.1 \\
2.4 \\
31 \\
2.1 \\
14.3 \\
9.7 \\
20.6 \\
11.8 \\
13.4 \\
2.6 \\
16.5 \\
18.7 \\
24.4 \\
43.5 \\
1.9 \\
13.5 \\
1.7 \\
11.0 \\
8.3 \\
5.3 \\
\end{array}$ & $\begin{array}{c}0.0012 \\
0.0007 \\
197 \\
0.113 \\
3.6 \\
0.0076 \\
0.167 \\
30 \\
5.9 \\
2.6 \\
0.046 \\
21.3 \\
36.6 \\
395 \\
0.067 \\
0.26 \\
0.013 \\
0.655 \\
0.95 \\
44 \\
0.53 \\
8.11 \\
7.85 \\
\end{array}$ & $\begin{array}{c}4.2 \\
5.6 \\
2.1 \\
6.4 \\
8.0 \\
27 \\
19 \\
1.0 \\
2.3 \\
2.2 \\
14 \\
1.5 \\
2.0 \\
1.3 \\
5.5 \\
2.6 \\
12 \\
15.7 \\
1.6 \\
9.4 \\
4.5 \\
2.2 \\
5.2 \\
\end{array}$ \\
\hline \multicolumn{11}{|c|}{ Group $B: \bar{E}_{\beta}$ is less accurately known than $\bar{E}_{\beta}$ in Group A } \\
\hline $\begin{array}{l}\mathrm{C} \\
\stackrel{\mathrm{S}}{\mathrm{Ca}} \\
\mathrm{Sr} \\
\mathrm{Y} \\
\mathrm{S} \mathrm{b} \\
\mathrm{I} \\
\mathrm{Au}\end{array}$ & $\begin{array}{r}6 \\
16 \\
20 \\
33 \\
39 \\
51 \\
53 \\
79 \\
\end{array}$ & $\begin{array}{r}14 \\
35 \\
45 \\
80 \\
90 \\
90 \\
124 \\
120 \\
193\end{array}$ & $\begin{array}{l}\beta^{-}, 0 \\
3^{-}: 0 \\
5^{-},(?) \\
3^{-}: 0 \\
5^{-}: 0 \\
5^{-}, 0 \\
5^{-}, \gamma \\
5^{-}, \gamma \\
5^{-}, \gamma\end{array}$ & $\begin{array}{c}1.7 \cdot 10^{6} \\
88 \\
180 \\
55 \\
9000 \\
2.6 \\
60 \\
0.017 \\
2.7 \\
\end{array}$ & $\begin{array}{l}0.05 \\
0.055 \\
0.10 \\
0.57 \\
0.22 \\
0.90 \\
0.66 \\
0.77 \\
0.32 \\
\end{array}$ & $\begin{array}{l}8 \cdot 10^{5} \\
420 \\
1580 \\
2760 \\
17 \cdot 10^{4} \\
200 \\
3480 \\
1.2 \\
75\end{array}$ & $\begin{array}{l}4 \cdot 10^{-7} \\
0.0079 \\
0.0039 \\
0.013 \\
8 \cdot 10^{-5} \\
0.24 \\
0.012 \\
1.0 \\
0.23 \\
\end{array}$ & $\begin{array}{c}32 \\
30 \\
16 \\
3 \\
8 \\
2 \\
2.4 \\
87 \\
5.7\end{array}$ & $\begin{array}{l}18 \cdot 104 \\
24 \\
62 \\
38 \\
6200 \\
18 \\
57 \\
0.017 \\
4 . x\end{array}$ & $\begin{array}{l}0.24 \\
0.2 \\
0.8 \\
7 \\
2.2 \\
11 \\
12.3 \\
9.8 \\
3.8 \\
\end{array}$ \\
\hline \multicolumn{11}{|c|}{ Group $C: \bar{E}_{\beta}$ includes the total localized $x$-radiation following decay by electron capture } \\
\hline $\begin{array}{l}\mathrm{Mn} \\
\mathrm{Fe} \\
\mathrm{Co} \\
\mathrm{Zn}\end{array}$ & $\begin{array}{l}25 \\
26 \\
27 \\
30\end{array}$ & $\begin{array}{l}57 \\
55 \\
53 \\
65\end{array}$ & $\begin{array}{l}K, \gamma \\
K^{+}, \gamma \\
\beta^{+}, K, \gamma \\
\beta^{+}, \gamma\end{array}$ & $\begin{array}{r}310 \\
1500 \\
65 \\
250\end{array}$ & $\begin{array}{l}0.0054 \\
0.0059 \\
0.035 \\
0.01\end{array}$ & $\begin{array}{r}147 \\
780 \\
20 \\
180\end{array}$ & $\begin{array}{l}0.0022 \\
4.6 \cdot 10 . \\
0.012 \\
0.003\end{array}$ & $\begin{array}{l}340 \\
280 \\
415 \\
185 \\
\end{array}$ & $\begin{array}{r}128 \\
633 \\
29 \\
124 \\
\end{array}$ & $\begin{array}{l}1.5 \\
1.2\end{array}$ \\
\hline
\end{tabular}

Group $D: \bar{E}_{\beta}$ consists of part of the radiation released in the decay by electron capture

\begin{tabular}{|c|c|c|c|c|c|c|c|c|c|c|}
\hline $\begin{array}{l}\text { Y } \\
\text { In }\end{array}$ & $\begin{array}{l}39 \\
49\end{array}$ & $\begin{array}{r}86 \\
111\end{array}$ & $\begin{array}{l}K, \gamma \\
K, \gamma\end{array}$ & $\begin{array}{l}105 \\
2.7\end{array}$ & $\begin{array}{l}0.005 \\
c .0058\end{array}$ & ${ }_{1.4}^{6}$ & $\begin{array}{l}0.007 \\
0 . \approx 3\end{array}$ & $\begin{array}{l}310 \\
310\end{array}$ & ${ }_{2.3}^{69}$ & 0.01 \\
\hline
\end{tabular}

$E_{\beta}=$ 平均エネルギー

$K_{\beta}=88 \bar{E}_{\beta} T=1 \mu \mathrm{cd} / \mathrm{g}$ の放射線量（rep）

$f_{a}=\left(1-e^{-\frac{0.693}{T}}\right)=24$ 時間内に崩壤するアイソトープ量

$S_{\beta}=\frac{0.1 \times 10^{3}}{K_{\beta} \times f d}=$ 最初の 24 時間に $0.1 \mathrm{rep}$ が照射されるアイソトープ濃度を $\mu \mathrm{c} / \mathrm{kg}$ で表わしたもの。

プが入っている場合の線量 $D_{r}$ 淀,

$D_{\gamma}=K_{\gamma} C g$ roentgens

で,

$$
K_{\gamma}=1.44 t I_{\gamma} \times 10^{-3}
$$

である。 $t$ は時間で表わした牛減期で，從っ

て $1.44 t$ 注本䚷壽命である。 $I_{r}$ 住 $1 \mathrm{mc}$ のアイ ソトープの點線源から空中 $1 \mathrm{~cm}$. の距離の線量 を 1 時間の $\mathrm{x}$ 量で示したものである。 $I_{\gamma}, K_{\gamma}$ 注第 1 圖，第 II 表 (次頁) の如く $\gamma$ 線のエネル ギーやアイソトープつ種類で定まり，崩壞率 $\left(P_{j}\right)$, 吸收係數 $\left(\mu_{j} e\right)$, 散筬係數 $\left(\sigma_{a}\right)$, 光電效果 係數 $(\sigma \tau)$ イオン對創生係數 $\left(\sigma_{p}\right)$ などに賢係 し, 毎秒の崩壇率注,

$$
\begin{aligned}
\left(i_{\gamma}\right)_{j} & =\frac{\left(3.7 \times 10^{7}\right) \times\left(3.9 \times 10^{20}\right)}{4 \pi\left(n_{i} \times W\right)} \\
& \times P_{j} \times E_{j} \mu_{j}{ }^{e} \quad \ldots \ldots \ldots \ldots \ldots \ldots \ldots
\end{aligned}
$$

但し,

$n_{i}=2.08 \therefore 10^{9}=$ 每靜電單位によって生ずる數

(3) Marinelli et al.: Rev. Mod. Physics, 19 (1947), 25.

(4) MARINELli et $a_{\lrcorner}^{\text {? }}$ : Nucleonics, 2 (1948), 56. 
第正表 $r$ 線線量の物理的尌測㒹 (Marinelli 等 (3),(4))

\begin{tabular}{|c|c|c|c|c|c|c|c|c|c|}
\hline \multirow{2}{*}{$\begin{array}{c}\text { Ele- } \\
\text { ment }\end{array}$} & \multirow[b]{2}{*}{$Z$} & \multirow[b]{2}{*}{$A$} & \multirow[b]{2}{*}{ Radiation } & \multirow{2}{*}{$\begin{array}{l}\ell^{\ell} \\
\text { Half life } \\
\text { in hours }\end{array}$} & \multicolumn{2}{|r|}{$E_{j}$ in $\mathrm{Mev}$} & \multirow{2}{*}{$\begin{array}{l}I \mathrm{\gamma} \\
\mathrm{at} \mathrm{I} \mathrm{cm} . \\
\mathrm{mr} / \mathrm{Mc} \cdot \mathrm{hr} \\
\mathrm{r} / \mathrm{mc} \cdot \mathrm{hr}\end{array}$} & \multirow{2}{*}{$\begin{array}{c}K \gamma \\
\text { at } \mathrm{r} \mathrm{cm} \\
\mathrm{r} / \mu \mathrm{cd}\end{array}$} & \multirow{2}{*}{$\begin{array}{c}f_{d} \\
\text { fraction } \\
\text { disintgr. } \\
\text { per dayr }\end{array}$} \\
\hline & & & & & $\begin{array}{c}\text { Annihilation } \\
\text { radiation }\end{array}$ & Nuclear gamma radiation & & & \\
\hline
\end{tabular}

Crjus A : elements not decaying by electron capture, or $\mathrm{x}$-ray emission following electron capture so soft that it can be

treated like beta radiation and hence making no significant contribation to $I \gamma$

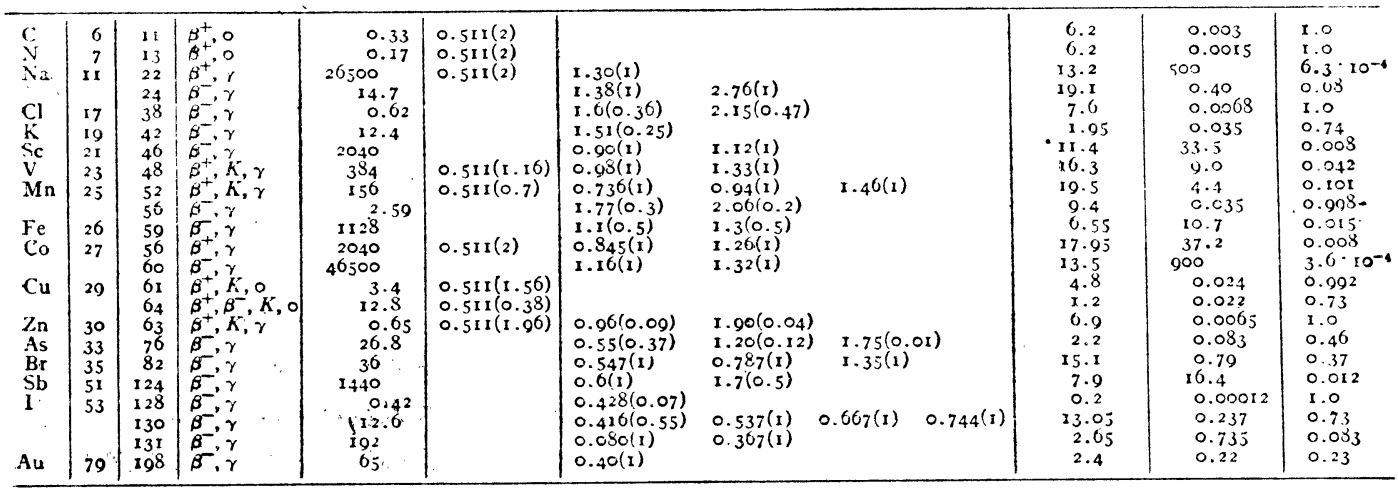

Group $B$ : elements with $x$-ray emission following electron capture whose contribution to $I \gamma$ is not negligible

\begin{tabular}{|c|c|c|c|c|c|c|c|c|c|c|c|}
\hline $\begin{array}{l}\text { Mn } \\
\text { Fe } \\
\text { Co } \\
\mathrm{Zn} \\
\mathbf{Y} \\
\text { In }\end{array}$ & $\begin{array}{l}25 \\
26 \\
27 \\
30 \\
39 \\
49\end{array}$ & $\begin{array}{r}54 \\
55 \\
58 \\
65 \\
86 \\
111\end{array}$ & $\begin{array}{l}K^{*}, \gamma \\
K^{+}, \gamma \\
\beta^{+}, K, \gamma \\
\beta^{+}, K, \gamma \\
K^{-}, \gamma \\
K, \gamma\end{array}$ & $\begin{array}{r}7450 \\
36000 \\
1560 \\
6000 \\
2530 \\
65\end{array}$ & $\begin{array}{l}0.511(0.3) \\
0.511(0.03)\end{array}$ & $\begin{array}{l}0.835(1) \\
0.07\left(2 \cdot 10^{-5}\right) \\
0.805(1) \\
1.14(0.46) \\
0.908(1) \\
0.173(1)\end{array}$ & $\begin{array}{l}1 . \varepsilon_{9}(1) \\
0.247(1)\end{array}$ & $\begin{array}{l}{[0.0054(1)]} \\
{[0.0055(1)]} \\
{[0.0004(0.85)]} \\
{[0.008(0.09)]} \\
{[0.0142(1)]} \\
{[0.0231(1)]}\end{array}$ & $\begin{array}{c}4.9+\left[\begin{array}{ll}1 & 1\end{array}\right] \\
{[10]} \\
5.7+[7] \\
3.0+[5] \\
14.4+[3.1] \\
2.3+[1.4]\end{array}$ & $\begin{array}{l}52 \\
\frac{52}{12.8} \\
26 \\
52.5+(10.3) \mid \\
0.22+|0.13|)\end{array}$ & $\begin{array}{l}0.0022 \\
4.6 \cdot 10^{-4} \\
0.012 \\
0.003 \\
0.007 \\
0.23\end{array}$ \\
\hline
\end{tabular}

$I_{\gamma}=1 \mathrm{mc}$ の無滤過點源より空中 $1 \mathrm{~cm}$. の距離の線量 $(\mathrm{r})$

$K_{\gamma}=1.44 t I_{\gamma} \times 10^{-3}=$ 同上の條件で $1 \mathrm{mcd}$ の線量

$f_{a}=\left(1-\partial^{-} \frac{0.693}{T}\right)=24$ 時間内に崩壤するアイソトープ量

$T=$ 本減期（日）。

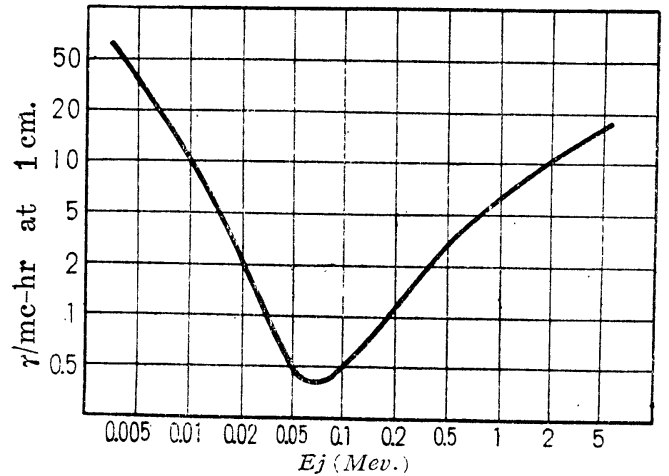

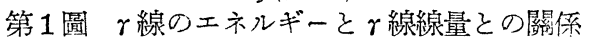

$W=32.2 \mathrm{ev}=1$ イオン對を名作るに要するエネルギー $\left.E_{j \mu j e}=E_{j}\left(\sigma_{2}+\tau\right)_{j}+E_{j}-2 \mathrm{~m}_{0} \mathrm{c}^{2}\right)\left(\sigma_{p}\right)_{j}$

$E j$ は $\gamma$ 線のエネルギー

であるので,

$\left(i_{\gamma}\right)_{j}=6.14 \times 10^{25} P_{j} E_{j} \mu_{j} e \mathrm{r} / \mathrm{mc}-\mathrm{h} / \mathrm{cm}$

$I_{r}=6.14 \times 10^{25} \sum_{j} P_{j} E_{j} \mu_{j}$ e (r)

から計算出來る。
第 (5) 式の $g$ 柱生體又は組織の大きさと形 態とによって定委幾何學的因子で，牛徑 $R$, 高さ $2 Z$, の圓壔とすると

$$
g_{i}=4 \pi \int_{0}^{Z} \int_{0}^{R} \frac{r d r d z}{r^{2}+z^{2}} e^{-\mu_{j} \sqrt{r^{2}+z^{2}}}
$$

の關係沉西り，又牛徑 $R$ の球であるとすると， 中心上り $S$ の距離の $g$ 注,

$$
g_{i}=\int_{0}^{R} \frac{4 \pi S^{2} d s}{S^{2}} e^{-\mu_{j} S}
$$

で， $R$ が $10 \mathrm{~cm}$. 以下で $S=0$ ならば

$$
g_{i}=4 \pi R\left(1-\mu_{j} \frac{R}{2}\right)-4 \pi R
$$

と极り， $S=R$ 疗ら，

$$
g_{i}=2 \pi R\left(1-\mu_{j} R\right)
$$

である。斯くして $g$ 老計算するととが出來る が，第 III 表から概算值を讀さと便利で西る。

\section{II. 安全追跡子濃度 (Safe Tracer Concen- tration)}


第吕表 $r$ 線量計測用幾何學的因子 $g$ の概算値

\begin{tabular}{|c|c|c|c|c|c|c|c|}
\hline & & & & 球 & & & \\
\hline $\begin{array}{l}\text { 平無. } \\
\text { (cm.) }\end{array}$ & \begin{tabular}{l|l}
1 & 2 \\
\end{tabular} & 3 & 4 & 6 & $\begin{array}{l:l}8 & 10\end{array}$ & 15 & 20 \\
\hline $\begin{array}{l}\text { 容積 } \\
\text { (cc.) }\end{array}$ & 4.233 .5 & 103 & 278 & 905 & $2,1404,18$ & 8014,15 & 027,800 \\
\hline$g$ & 12.625 .2 & 37.8 & 50. & 475.6 & $101 \quad 12$ & \begin{tabular}{l|l}
6 & 189
\end{tabular} & 252 \\
\hline & & 圓 & & & 筒 & & \\
\hline $\begin{array}{l}\text { 直 兴 } \\
\text { (cm.) }\end{array}$ & & & 6 & 10 & 16 & 24 & 40 \\
\hline $\begin{array}{l}\text { 高 ざ } \\
\text { (cm.) }\end{array}$ & & & 10 & 16 & 30 & 40 & 60 \\
\hline $\begin{array}{l}\text { 容 積 } \\
\text { (cc.) }\end{array}$ & & 28 & & 1,260 & 6,000 & 18,000 & 76,000 \\
\hline$g$ & & 45. & & 73 & 108 & 156 & 214 \\
\hline
\end{tabular}

アイソトープを人體に投與し，當初の 24 時間 飞全身が $0.1 \mathrm{rep}$ 照射されるアイソトープ投與 量を體重 kg.當り $\mu \mathrm{c}$ の量で表わしたもので, $\beta$ 線のみ就いて第 I 表中に $S_{\beta}$ として示 してある。

$$
\begin{aligned}
& S_{\beta}=\frac{0.1 \times 10^{3}}{K_{\beta} \times f_{d}} \\
& S_{\gamma}=\frac{0.1 \times 10^{3}}{K_{\gamma} \times f_{d}}
\end{aligned}
$$

$f_{d}$ は 1 日の崩壞率で, $K_{\beta}, K_{r}, f_{d}$ 注第 I, II 表 に記して西るから，关れから計算出來る。組 織毎の線量注吸收率較差を計算に入れて考慮世 ねばをらず, 少くこる贜器毎の安全濃度を算出 し，三の範圍で追跡實驗を行わねばならない。 例えば $\mathrm{Ca}^{45}$ の $S_{\beta}$ は全身江就いては第 I 表 より $16 \mu_{c} / \mathrm{kg}$. であるが，骨への D.A.R.= 15.6, 骨の重量は體重の約 $10 \%$ であるから,

$$
16.6 \times \frac{10}{100}=0.1 \mu \mathrm{r} / \mathrm{kg} \text {. }
$$

となり，50 kg.の人では $5 \mu \mathrm{c}$ よ投與出來ず， 從って，人體で $\mathrm{Ca}^{45}$ を用いて追跡實驗を行ら こと柱非常に危險が大きく，更沉骨での吸收率 の大きいととや骨髓溸する作用などを考慮す ろと實行不可能なとと分分る。然か子壽命が長 くて，一度沈着すると中々排泄されないから，

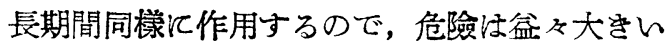
ととになる。

\section{IV. 㟝嗞上への應用}

醫學上の追跡子實驗は實汇廣範であるが，こ のらち既に人體に直接應用して診斷上に利用さ れている主な方法を列記する。

\section{1. 话㻖血整並びに血球量の测定}

\section{(1) $\mathrm{P}^{32}$ 汇よる測定}

血揫量を測るには Evans blue なぼの色素 を用万る方法があり，血球量測定飞は一酸化炭 素法 (CO) があるが，アイソトープを應用する 方法は又特別な正確さを示するので西る。 $\mathrm{P}^{32}$ を應用したのは Hevesy 及び Hahn 江始まる。

(i) Hevesy 法(5) 被檢者の肘靜脉から 約 8cc. 採血，へパソンと $\mathrm{Na}_{2} \mathrm{HP}^{\circ 2} \mathrm{O}_{4} 30 \sim 50 \mu \mathrm{c}$

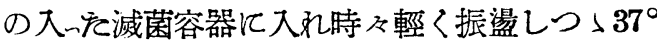
C 1 2 2時間保ち,遠心乙て血漿を分離放育し, 滅 菌生理食覧水を加え振盪後遠心乙，上清を棄て 万。同樣の操作を 3 回反復して洗涤し, $\mathrm{P}^{32}$ 札 付を赤血球を得ると 1 時間以內に $\mathrm{P}^{32}$ を離すて と忟なん。その牛量を被檢者の肘静脉より注射 乙，1時間以來江數回採血乙て測定洪する。 $\mathrm{P}^{32}$ 札付を赤血球液 $1 \mathrm{cc}$. の放射能亡,注射後探 血した血液 $1 \mathrm{cc}$. の放射能との比を $B$, 注射乙 ॠ $\mathrm{P}^{32}$ 札付き赤血球量を $A$ とすると, 循環赤 血球量は $A \times B$ である。

(ii) Kelly 法(6) Hevesy と同樣の方法 で $\mathbf{P}^{32}$ 札付を赤血球を作り，てれを注射し，探 血して試料とする事は同樣で西るが，注射後採 血しを試料からへマトクリット值 $\left(\mathrm{H}_{2}\right)$ を測定す る。 $\mathrm{P}^{32}$ 札付き赤血球液 $1 \mathrm{cc}$. の放射能を $C_{1}$, 注射後採血した試料 1cc.の放射能を $C_{2}, \mathrm{P}^{32}$ 札 付を血球液の注射量を $V$ とすると,

$$
\begin{aligned}
& \text { 全血液量 }=V \times \frac{C_{1}}{C_{2}} \\
& \text { 循環赤血球量 }=V \times \frac{C_{1}}{C_{2}} \times \frac{\mathrm{H}_{2}}{100} \\
& \text { 血漿量 }=\text { 全血液量 }- \text { 循環赤血球量 }
\end{aligned}
$$

である。こっでは，注射後適當の時間がたてば $\mathrm{P}^{32}$ 札付を赤血球之普通赤血球とが一定の比で 混じているるのと見做す。

（iii） Reid 等の方法(i) 採血量注 6〜8cc. .

(5) Hevesy et al.: Acta Med. Scand., 116 (1944), 561.

(6) KELLY et al.: J. Clin. Invest., 27 (1948), 785.

(7) REID et al: J. Clin. Invest., 29 (1950), 313. 
ヘパリンと $100 \mu \mathrm{c}$ の $\mathrm{P}^{32}$ とを加え, $37^{\circ} \mathrm{C} 30$ 分間保溫し，遠心して血繁を分離除去し， $\mathrm{pH}$ 7.4 の燐酸ソーダ加食掔水で數回洗沙し, 同液 で 10 cc. とし，その $5 \mathrm{cc}$.を靜注し，20 分間䚾 10 cc. 採血し, ヘパリンで凝血を防ぐ。 $\mathrm{P}^{32}$ 札 付を赤血球原液を 400 倍汇稀釋して放射能測定 飞供すると $\left(C_{1}\right)$ 循環血液量は,

$$
400 \times 5 \times \frac{C_{1}{ }^{\prime}}{C_{2}} \text { (cc.) }
$$

で㐫る。

(iv) Nachmann 等の方法 Evans blue 乞 $\mathrm{P}^{32}$ 札付を赤血球とを共飞注射する方法で, 三方括栓付等注射針老用い，

第一にヘマトクリット值測定のをめに採血し，

第二飞 Evans blue 5 cc. 老注射,

第三に引湑を $\mathrm{P}^{32}$ 札付き赤血球夜を $10 \mathrm{c}$.注 射乙,

$12,23,30,45,60$ 分後汇採血与る。遠心 試驗管飞入れ，1 分間 3,000 回轉 45 分間遠心乙 てへマトクリット值を計った各色素濃度を光電 比色計 (Spectro-photometer)で測る。遠心管 に $0.1 \%$ 炭酸ソーダ液を正確に血液と同容積だ け加え，振盪して血球を溶血せしめる。 $\mathrm{P}^{32}$ 札 付き赤血球浮游液汇滅菌水学加えて 100 倍稀釋 する。各試驗管から正確江 $0.1 \mathrm{cc}$. 孝測定血源 ピペツトで取り, 10\% Aerosol OT夜 (Dioctyl sodium sulfosaccinate） 1 滴を加之平等飞揎 げ, 室溫で 30 分間乾かし, ガイガー計數器で測 定する。

$$
\text { 赤血球量 }=\frac{C_{1}}{C_{2}} \times E
$$

$E$ は注射した赤血球量 (cc.), $C_{1}, C_{2}$, は注射 前後の血球の counts/min./cc.

乙の場合，色素法と $\mathrm{P}^{32}$ 法との值を比較する 之 $\mathrm{P}^{32}$ 法の方がー般化少く, Evans blue 值の 0.87 (Reeve), 0.99 (Mayerson) 等が報告され ている。

(2) ${ }_{24} \mathrm{Cr}^{51}$ 上万測定

$\mathrm{C}_{\gamma}{ }^{51}$ で $\mathrm{Na}_{2} \mathrm{Cr}^{51} \mathrm{O}_{4}$ を作り，血液に混ずると血 清蛋白や血球飞結合して丁5。丁度 $\mathrm{Na}_{2} \mathrm{HP}^{32} \mathrm{O}_{4}$
や $I^{131}$ を使用してやったのと同じ目的に使用出 來るのみならず，1度結合すると中々離れない

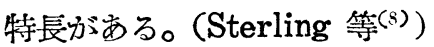

40〜203 $\mu \mathrm{c}$ の $\mathrm{Na}_{2} \mathrm{Cr}^{51} \mathrm{O}_{4}$ を 50 cc. の血液 飞混さ，放射性の血球や放射性の血漿プロテイ ンを得る。このものは 48 時間以內は絕對に放 射性物質を離すととがないので，血球量を測定 するのに最近は $\mathrm{P}^{32}$ より好んで使用される樣に なった。

（3） $\mathrm{Fe}^{59}$ 及び $\mathrm{I}^{131}$ とよる 循環血量測定法

$\mathrm{Fe}^{59}$ 又惊 $\mathrm{Fe}^{45}$ でへモグロビンを札付けする と全く離れなくなる。 $\mathrm{P}^{32}$ や $\mathrm{I}^{131}$ で札付けする と，比較的短時間に放つので，或ろ種の實驗に は鐵の方がよい。ての際に鐵は長〈體內に止り， 然もとの牛減期が長んので, 放射線障害を來す 危險のあるととを考慮るて使用しなければなら ない。

同一血型の給血者飞敬椂酸アンモニッム鐵の 型で $\mathrm{Fe}^{59}$ を20〜50 $\mu \mathrm{c}$ 投與すると，1日後に はへモグェビン內に放射能を證明し得，投與後 21 日目に最大の放射能を持つようになる。ての 頃給血者より探血し, $\mathbf{F e}^{59}$ 札付を血球を得る。 給血量を $C d$, 給血者の血球の放射能の强さ崖 $U a D$, 被檢者の血球の放射能の强さを $U a R$ 之 方々と, 被檢者の赤血球量 $V_{r r}$ 注

$$
V_{r r}=\frac{C d \times U a}{U a R}
$$

である。

多くの人の實驗結果は $\mathrm{P}^{32}$ で札付をしね場合 と同樣で西るが，Gibson 等(9)が報告している 樣にこみいった實驗が出來る。例えば Gibson 等(9)は $\mathrm{I}^{131}$ で血漿を札付けて，Fe $\mathrm{e}^{59}$ で札付け した赤血球の一定量を注射して 1 時間後及び 3 ５ 時間後飞動脉静脉及び右心耳より探血し， 更に動物を屠殺して, 各臟器を取り出し, その 中のへモグロビン量, $\mathrm{I}^{131}$ 及び $\mathrm{Fe}^{59}$ の放射能 老測定して見を所，大血管又は心臟內の血液よ り，臟器內の小血管の血液の方がへアトクリッ ト值が低いが，赤血球の放射能注一定である事

(8) Sterling et al.: J. Clin. Invest., 29 (1950) 1604, 1614.

(9) GiBson et al.: J. Cin. Invest., 25 (1946), 616, 838. 
を證明した。Dow 等(111) $\mathrm{Fe}^{59}$ で札付けした 赤血球を Evans blue 液とを混じて直接上大静 脉注㴬し，大動脉より採血して小循環內に於 ける色素或注赤血球の筃滞考追究した所, 小 循環內には血漿も血球も共に少しる停溲せぬと と分明かとをった。

\section{2. 循環時間の測定}

Blumgart ${ }^{(1 i)}$ 注 Rac 老便って初めて循環速 度を計ったが，Friedell 等が $\mathrm{P}^{32}$ 老使用して から簡單に行わ礼るよになった。 $\mathrm{P}^{32} 200 \mu \mathrm{c}$ 老生理食監水 $10 \mathrm{cc}$. 几大れ, 急速飞注射乙, 毎 秒 2 滴宛アルミ板上に採血して, 乾燥後ガイガ 一計數器で測定する。而して放射能の强くなる 迄の時間它調べる。

$\mathrm{Na}^{2 \cdot 4}$ による循環時間の測定として注，

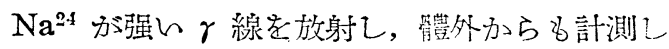
得るので, 或る部 (例えば上㬍) の靜脈より等 張の $\mathrm{Na}^{2-1} \mathrm{Cl}$ 液定注入乙, 他部（例えば下腿） にガイガー管又はシンチレーション管を設置し て置いて，注射後出現までの時間を測定すれば 循環時間分簡單汇求められる。

昁循環の模樣克知らんとするならば，測定管 を心窝部汇密着して置き, 數 cc. 中に 100 200 $\mu \mathrm{c}$ の $\mathrm{Na}{ }^{24} \mathrm{Cl}$ の大った液急速に肘靜脈上り 注射し, 自動台钎錄器飞上って連續的飞記錄す ると分る。Prinzmetal 等(12) は之它 Radiocardiography 已命名し,第2圖の如き結果老得
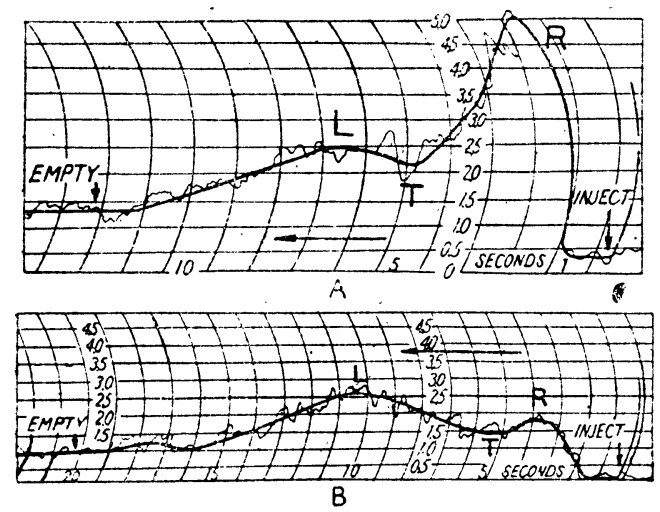

第 2 圖 Radio Cardiograph (Prinzmetal 等(12))
た。心臟並び肺循環汇障碍のある際江種々の 變化が見られ，診镍の補助とする事が出來る。 时靜脈より同樣沉して $\mathrm{Na}^{24} \mathrm{Cl}$ 它注射し，足 蹠酒測定管を接着させて, 肘から足蹠までの循 環時間を測定した Smith 及び Quimby(13) の 結果社第 IV 表の如くで, 種々の血管疾患等の 診斷の參考汇存る。

\section{第闵表 手より足への循環時間}

(Smith 文び Quimby)

\begin{tabular}{|c|c|c|c|}
\hline 斷 & 痽例數 & 循環時間 & 本均傎 \\
\hline 動 脈 硬 & 24例 & $20-105$ 秒 & 45 秒 \\
\hline 動胍硬化症已糖尿病 & 13 & $29-90$ & 42 \\
\hline 動脈硬化・糖尿病と化膿 & 5 & $20-40$ & 27 \\
\hline 閉鎖性血管栓塞 症 & 12 & $20-70$ & 33 \\
\hline 皮 & 5 & $15-75$ & 44 \\
\hline 慢性 靜 脈 瘤 潰 痬 & 3 & $30-45$ & 38 \\
\hline 高 & 13 & $20-80$ & 41 \\
\hline 凍 傷 後 & 6 & $25-60$ & 43 \\
\hline 他 & 39 & $15-75$ & 34 \\
\hline 正 & 11 & $20-55$ & 43 \\
\hline 全 & 131 & $15-105$ & 39 \\
\hline
\end{tabular}

$\mathrm{Na}^{24} \mathrm{Cl}$ 学靜注後四肢等で放射能の出現老測 定する己，先す血管內江出現するのが測定され， 次んで，て事が組織間液に浸入して來るので， 次第汇計測值が霄加し，血管內外の $\mathrm{Na}^{24}$ が本 衡に達すると一定の值となる。之老時間的に記 錄すると曲線が畫か礼，Quimby 等注之学 Build-up curve 亡呼び, 正常者では第 3 圖つ如 く一定の動遥範圍內汇をる。然るに種々の血管 系の疾患があると，異った曲線を描くよう沉な る (Quimby, Mufson 等)。とのような血管疾 患の西患者索治療すると, との曲線が變化す る (次頁) (第 4 圖)。

周樣の理により，血管摃張劑や縮少劑の藥理

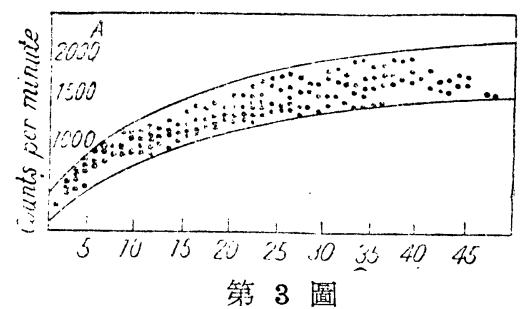

正常者の Build-up curve (Quimby 等(13))

(10) Dow et al.: Am. J. Physioı., 147 (1949), 493.

(11) Blumgart et al.: J. Clin Inqest., 4 (1927), 15.

(12) PRINZMETAL et $a^{\prime} .:$ A. J. M. A., 139 (1949), 617.

(13) SMith \& QuimBY: Radiology, 45 (1945), 335. 


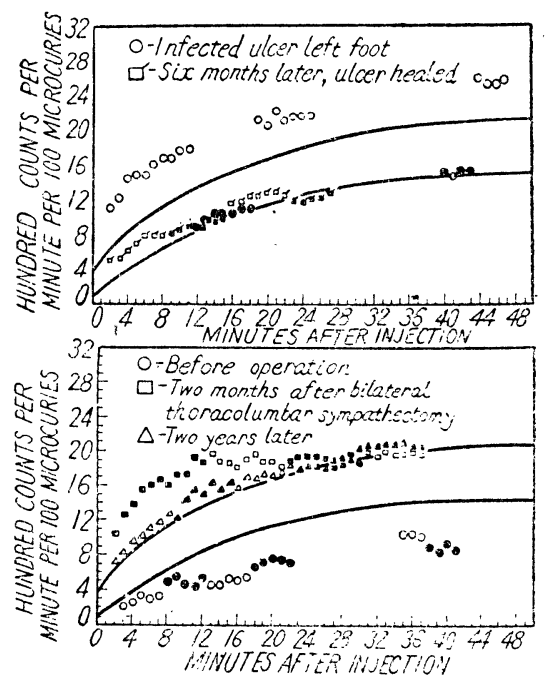

第 4 圖

治潦前後の Build-up curve (Smith 等 ${ }^{(13)}$ )

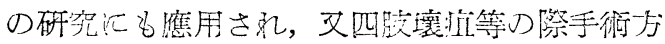
法や手衔部位心沃定上飞子役立つ。

Kety, Coopev 等(14) 注 $\mathrm{Na}^{2+4}$ 表筋肉內汇注射

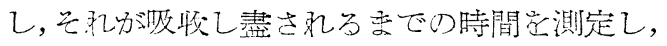
逆汇循環系り陪碍け存否定判定した, 郎与5 の等張 $\mathrm{Na}^{2.9} \mathrm{Cl}$ 液 $(0.5 \sim 1.0$ cc. と寸) 死排腸

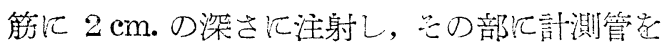
接着し，1 分每汇部測して減衰曲線攰畫く之，

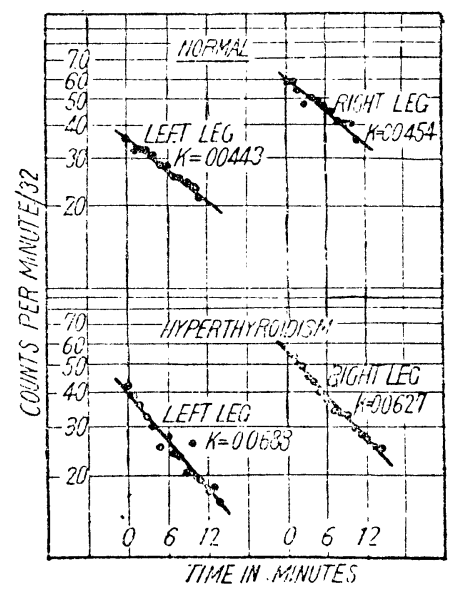

第 5 圆

$\mathrm{Na}^{2 \div}$ の筋肉よりの吸收曲繶（Elkin Cooper 等(4)）
注射後 $t$ 時間後の計測值. $Q$ は,

$$
Q=Q_{0} e^{-K t}
$$

となる。Q 0 汇注射直後の計測值で, $e$ は自然對 數の底值, $k$ 证常數で, $t_{1}$ 時负び $t_{2}$ 時の計測 值总气れぞれ $Q_{1}, Q_{2}$ と寸方之，

$$
k=\frac{\log Q_{1}-\log Q_{2}}{0.4343\left(t_{2}-t_{1}\right)}
$$

で求められる。寊驗結果注第 5 圖の如くで, 正 常者で活すべて指數曲線考表称し，大體每分 5 \%の割合で減袞してゆく。若し膝蓋部の上に止 血帶它施世ば，ての減衰注著しく阻害され，後 除去すると，減表速度正常の倍以上に早く极 る。注射後腓腸筋孝運動さ也当已減衰曲線注促 進され, 注射液汇アドレテリン老加元て置くと

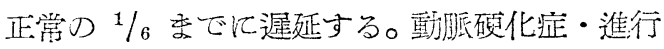
した肉頳性血栓性血管炎・四肢浮腫の西龟者 で汇逮延方涀られ，高血壓・甲狀腺機能元淮者・ 血栓性靜脈炎等では促進が見ら机る。

\section{3. 消化管の吸收並びに排浙}

(1) ヨ゙ード

$I^{131}$ は腸管からの吸收率か渄常汇よいので， 今日でも經口的投與が專ら應用されている。診 斷气の他の追跡賔驗汇於ける人體への投與量注

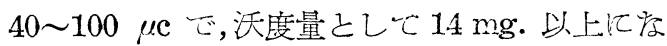
る己, 甲狀腺への沃度攝取量の限界汇達与万の で，時間的分布率か變って來万。

(2) ナトリム

クロール・カリゥム䄈ぞと共汇組織細胞の內

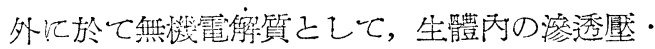
酸監基本衡の維持・水代謝等飞重要孝役割在演 じてている。 $\mathrm{Na}$ と C 己 己注主として細胞外液

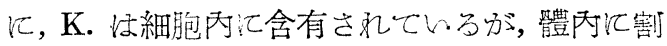
合に平等化分布する事方特長である。

$\mathrm{Na}^{24}$ を $\mathrm{NaCl}$ の形で注射する之數分後に注血 等內で殆ぞ平衡汇達し， $\mathrm{Na}{ }^{2 \cdot 4} \mathrm{Cl}$ 老經口的飞投與 しそ場合汇る 3〜6 分で血中汇現われ，3〜10時 間で平衡汇卖する (Hamilton $^{(15)}$ )。斯の如く, 投與されそ $\mathrm{Na}^{24}$ が非常に短時閣で體中に擴が

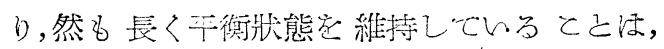
$\mathrm{Na}^{24}$ が血管と畒胞外液相との間で䚷等化される

(1:) COOPER et aj.: Smg. Gyn. Obst., 85 (1949), 711.

(15) Hamilton: Am. jo. Qhysiol., 124 (1938), 667. 
ととを意味し，一方排泄が緩除であるためであ ろ。

$\mathrm{Na}$ の排泄は尿路・消化管・肝腺種及の經路 があるが，その大部分は腎獩からである。腎臟

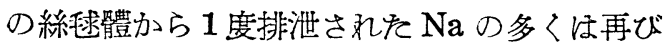
細尿管から吸收されて, 尿中出るの注少くて, $\mathrm{Na}^{21}$ 投與後 1 時間以內江标 $1 \%$ 以下で，3 日間 に 12.5\%に過ぎない (Hevesy $\left.{ }^{(16)}\right)$ 。日常食物

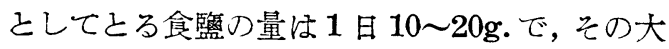
部分が吸收されるから， Na は 3 8g. 攝取され る譯で，その位の量が排泄されるが攝取された そのもの小排泄江その僅か一部過ぎい。

心臟疾患・腎臟疾患等の時飞は, $\mathrm{Na}^{24}$ の分 布や排泄の狀態が變って來る。心不全があって 浮腫が起るような場合には細胞外液への $\mathrm{Na} の$ 滲透が正常者より遙か汇高度となり，血漿の 2 倍の速さに達し, 浮腫のある處飞多量飞貯溜す る。祘浮腫液內への滲透は腹水一のそれ上り 速かで西ると言う (Reaser 等(1i) 腎臟疾患で 浮腫の西患者で注尿中への Na が減じ, 體液 中の $\mathrm{Na}$ が增し, 利尿が艺進しても, $\mathrm{Na}$ の排泄 注急江增さをん。細尿管からの再吸收が障碍 されると逆淿尿中の $\mathrm{Na}$ 量が增す事が西る。

(3) クロール

クロールもナトリッムと同樣に, 主としで細 胞外液相にあり, 細胞內には極めて少いが, ク ロール浾血球內に割合に入る。 $\mathrm{Cl}^{36}$ を用いて 消化管汃らの吸收を見ると, $\mathrm{Na}^{2-4}$ 上り㜊く, $\mathrm{K}^{42}$

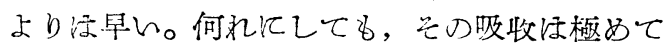
早く，又殆ど大部分が吸收されて了万。生體內 での分布は, 細胞外液相にナトリッム上り忹分 布地が稍と少く, 細胞外液相の測定をするのに は不利である。

Manery 等(18) $\mathrm{LiCl}^{38}$ の $0.2 \mathrm{mc}$ 党の耳

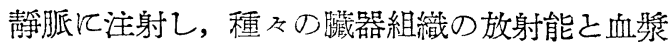
の放射能と老比較して, 所謂 “Chloride space” 老測定した。こつ際 $\mathrm{Cl}^{3 i}$ 古含む組織液相の計 算は次式汇よった。

$$
\begin{aligned}
& \left(\mathrm{H}_{2} \mathrm{O}\right) \mathrm{ECI}^{39}=\frac{\text { 組織 } 1 \mathrm{~g} . \sigma \text { 放射能 }}{\text { 血獎 } 1 \mathrm{cc} . \text { 放射能 }} \\
& \times 0.95 \times 0.93 \times 100
\end{aligned}
$$

乙っで $\mathrm{H}_{2} \mathrm{O}$ 相注新鮮な組織 $100 \mathrm{~g}$. 飞就々て の量を $\mathrm{g}$ 數で表わしたるのであり，0.95 は Gibbs-Donnan ratio, 0.93 注血漿炕含委秃了 水分飞對する補正である。 $\mathrm{Cl}^{36}$ の放射能索利用 して計測した種々の組織液相の值は, 化學的に 定量した價己極めて近似している。てのてと汪 種々の組織液內の $\mathrm{CJ}^{35}$ イオンは細胞外液中の $\mathrm{Cl}^{38}$ と容易汇交換されるとと礼示している。

クロールの排泄は腎臟・消化器・汗腺等が主 で西る。婜臟の絲垡體から排泄されたるの注細 尿管から $99.4 \%$ 再吸收されて了ら。乙か乙て 食物己共江攝取されそ位の量が尿中に出る。消 化管は胃の盬酸等つ形で排泄されるが，再吸收

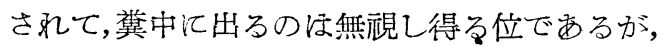

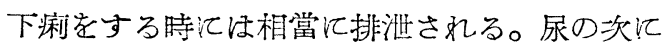
大きいの汗への分泌で, 發汗の激しい時汇社 汗からの褧失は相當量に達する。

腎臟疾患の際汇活クロールの排泄が減して, 血漿中のクロール濃度が柏し，浮腫索來す。肺 炎の際にもクロールの排泄が減じて來るが，血

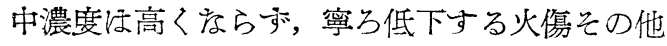
のショック時, 傳染病その他の有熱疾患でもクロ ールの排泄泛減少する。

Addison 氏病乞の他の副腎機能障碍が西る 之, 腎臟に於けるクロールの再吸收が不允分之 なり，低クロ一ル症孝來す。糖尿病・心臟疾患 等でるクロール分布の異常を來するので㐫り, 從來化學的の測定に上って，色たの專が云わ秃 ているが，アイソトープを用いて，深く研究し を報告注未殆ど見當らない。

(4) カリゥム

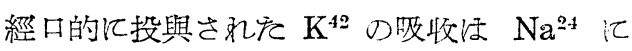
比して遙かに掘く，3 倍以上の時間を要する (Hamilton 等(15))。多量のカリッム老投與す

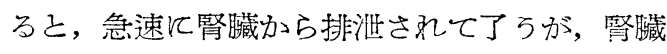

(16) Hevesy: Acta Physiol. Scand., 3 (1942), 123.

(17) Reaser et aj.: Proc. Soc. Exp.. Biol. Med., 63 (1946), 543.

(18) MANery et a a.: Am. J. Physiol, 134 (1941), 83. 
ほカリッムを過度飞失わないようと作用し，細 尿管からの再吸收が盛んで，上く調節される。

\section{4. 細胞外液量の測定}

細胞外液 (Extracellular Fluid) の定量に は, SCN', Br', 䓞糖, イヌリン・マニトール等 が用いられるが,一般には NaSCN が使われる。 NaSCN は排泄が緩慢である反面, 赤血球及び 腺組織細胞內に侵入乙，その制定に迷万怖れが 西る。然るに, $\mathrm{Na}^{24}$ ほ主飞細胞外液飞擴散し,

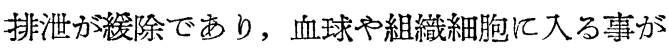
極めて少く，且つて不を注射する時汇速かに平 衡狀態飞達するので, $\mathrm{Na}^{24}$ の放射能を利用し て細胞外液の測定を行らととが最も合理的とさ れている。

その測定法は一定量 $(100 \sim 200 \mu \mathrm{c})$ の $\mathrm{Na}^{24}$ Cl 在注射後 3 時間以內 その放射能を測定すると, 細胞外液總量 $\left(V_{2}\right)$ は

$$
V_{2} \frac{C_{1}}{C_{2}} V_{1}
$$

$C_{1}=$ 注射に用いた $\mathrm{Na}^{2+} 1 \mathrm{cc}$. 中の放射能

$V_{1}=\mathrm{Na}^{24} \mathrm{Cl}$ の注射量 (cc.)

$C^{2}=$ 一定時後の血液 1ec. 中の放射能

である。Evans blue 法又任 Trypan red 法で 同時汇循環血漿量它計り，そ礼考差引けば，血

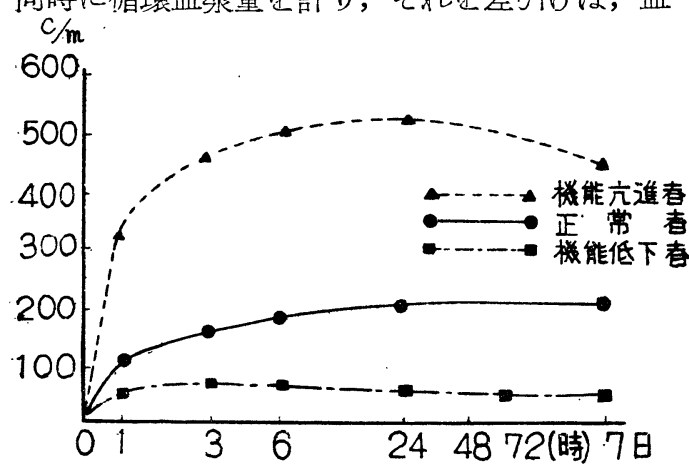

* conts/min.

皮署 G.M.管距離 $20 \mathrm{~cm}$.
管外の細胞外液量をる知る事が出來る。ての方 法で測定した，正常人體の細胞外液量の體重に 對する比, 即ち “Sodium space” $21 \%$ (Kaltreiter 等(19)) 或いは 23〜29\% (Griffi-

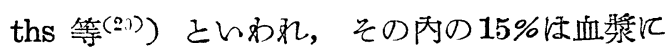
85\%は血管外細胞間液江存する。幼兒では細胞 外液量が多く, 成人の略々 1.7 倍で西るとい5 (Flexner 等(21)）なお $\mathrm{Na}^{24}$ 亿よる細胞外液量 ほ NaSCN により測定せる價より幾分高い。

重水 $\left(\mathrm{D}_{2} \mathrm{O}\right)$ 三重水素 (Tritium) 或々は Antipyrin 者用いて全身水量を計り，てれに循 環血漿量・細胞外液量等を組合せて種ふの實驗 をする事它面白い(Vorburgh 等(22)

\section{5. 甲狀腺機能檢查}

初期には $I^{13 n}$ る相當應用されたが、今日では 專ら Carier-free の I ${ }^{131}$ が使用されている。 追跡子量としてて 50〜100 $\mu \mathrm{c} の I^{131}$ 孝經口的 飞投與すると，甲狀腺機能に準ざ甲爿腺に $I^{131}$ が蓄積する。時間を追って檢査すると，第 6 圖の如くで, 3〜 6 時間で最高飞達し, 乞礼か

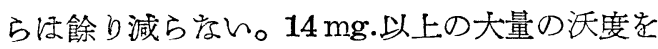
與えて置くか，或注 Thisuracil 等のホルモン を授與すると機能立淮它る甲狀腺や正常の甲狀 腺に $\mathrm{I}^{131}$ が入らなくなり，逆飞或種の甲狀腺腫 によく攝取されるようになる。

Miller 等(23) ほ尿中への $I^{131}$ 排泄量が甲狀腺 への蓄積量己逆比例するので，48時間尿の $\mathrm{I}^{131}$ を測定して，そ礼から甲狀腺機能を逆算する方 法老行った（第 $\mathrm{V}$ 表參照）。

第 $\mathrm{V}$ 表 $I^{131}$ の尿中排泄率（著者）

\begin{tabular}{|c|c|c|c|}
\hline 疾 患別 & 例數 & 動 摇 值 & 本均値 \\
\hline 機能元進者 & 21 & $10.0 \sim 50.0 \%$ & $32.0 \%$ \\
\hline 正 常 者 & 7 & $61.1 \sim 62.6 \%$ & $58.5 \%$ \\
\hline 機能低下者 & 2 & $84.0 \sim 87.0 \%$ & $85.8 \%$ \\
\hline
\end{tabular}

第 6 圖 $I^{131}$ の甲狀腺攝取量の時間的經過（著者）

(19) KALTREITER et al.: J. Exp. Med., 74 (1941), 569.

(20) GRIFFITHS et al.: Nature, 143 (1939), 159.

(21) FleXNer et al.: J. Pediat., 30 (1947), 413.

(22) VoRBurgh et al.: Am. J. Obst. Gyn., 56 (1948), 1156.

(23) Miller and Sol.ey: M. Clin. North Am., 23 (1948), 3.

(24) RAwSON: J. Clin. Invest., 28 (1948), 1,330. 
第 $\mathrm{I}$ 表 $\mathrm{I}^{131}$ の甲狀腺攝取率 (著者)

\begin{tabular}{l|rccc} 
疾患者 & 例數 & 動 摇 & 值 & 平均值 \\
機能克淮者 & 21 & $32.0 \sim 78.0 \%$ & $54.0 \%$ \\
正 常 者 & 7 & $17.0 \sim 35.9 \%$ & $25.0 \%$ \\
機能低下者 & 2 & $6 \sim 9 \%$ & $7.5 \%$ \\
\hline
\end{tabular}

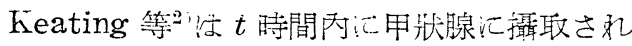
万量老 $Q$, 甲爿腺の最高摄取量艺 $Q J$ 上すると, 血中よりの消化率 $(r)$ 注，

$$
r=\frac{-\log \left(Q_{f}-Q\right)+\log \left(Q_{f}\right)}{t \log e}(\%)
$$

で，正常機能者で活 $2.4 \pm 0.7 \%$ ，甲罗䗆堙で 4. $6 \pm 1.3 \%$, 甲狀腺栈能卉進者心 $20 \pm 5.6 \%$,

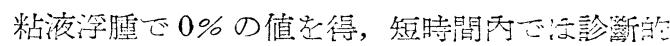

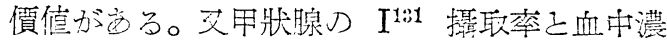

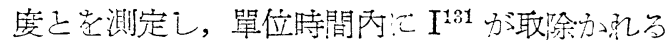
血液量 (cc.) 厄゙表わ乙血中清排率 (Thyroid clearnnce rate) とすうと, 正常㘳こ $6.2 \mathrm{cc}$, 機能克進者で $82.9 \mathrm{cc}$. 脑る。

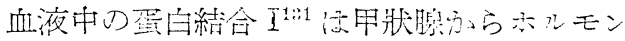

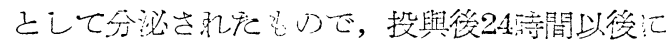

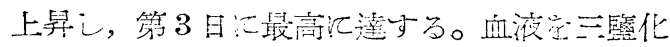

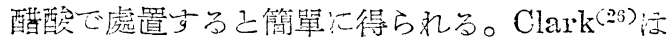

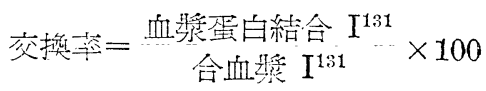

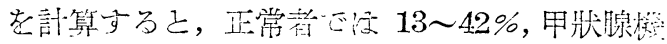

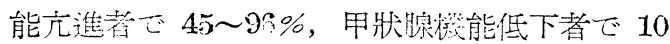
\%以下で，测完値の重り合ひ（Overlapping）

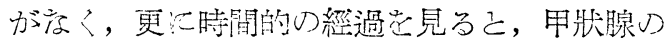

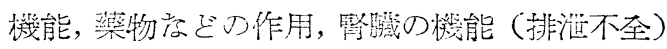
などを同時て知らととが出㭃るので，今日最も 優㣗た檢查法で西る。微量の $I^{131}$ の測定汇法シ ンチレーション管の應用が能率的で, Allen 灭

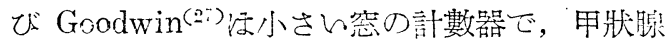

の大きさまで正確汇測定する方注芯考案した。

\section{6. 分血の診斷}

貧血せ万るつ注鐵つ吸收率活高く, 正常つ 5 〜8倍汇達し，并の體內ての移動狀態も異る(2)。 $\mathrm{Fe}^{59}$ 学注射した後飞探血し宛赤球から Hemin t抽出し, Hemin の放射能乙全血の放 身能已老比較する己鐵の利用率が分る。鐵缺之 食にしたもの注，鐵投與量の如何江不拘，鐵つ 吸收之利用之が迅速で㐫らが，Pyridoxine 缺

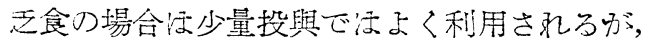
大量投與で注利用率が低下する。正常者で注佂

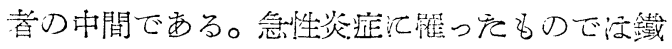
の利用率经非常低低く, 又慢性炎症安持ってい うるので注ない層低率で亩る。斯かる炎还性

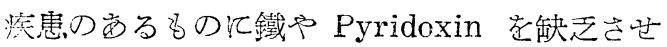

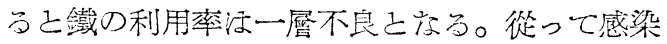

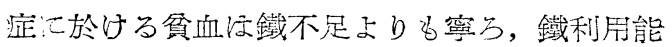
力つ低下に上るので㐫る上推諭される。鐵の利

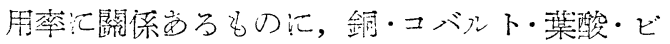
夕ミン類等が西る。吉川等(2)依放射性銅 $\mathrm{Cu}^{(6 * *}$ 老與元る之鐵の利用率が高要り，逐行銅の缺之 食とすると，鐵の利用率が低下乙，貿血在起す

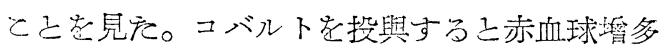
症起來すととが知られ，ビタミン $\mathrm{B}_{12}$ や葉酸上

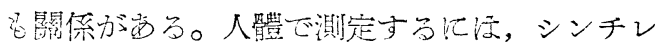
ーション管安用い民 Counting rate meter だ 竍测する。

\section{7. 皮膚及び粘膜の吸収亡排渫}

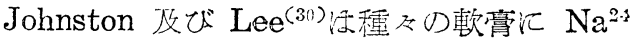

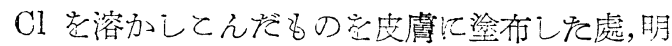
か汇吸收さ礼歹のを認的展。

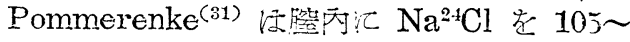
$150 \mu \mathrm{c}$ 索 $10 \mathrm{cc}$. の水汇溶加して捙大し, 種飞 の時間飞探血して放射能文檢查し志所，相當の

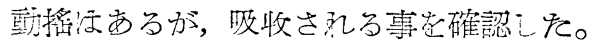

(25) Keating et al.: J. Clin. Endocl., 9 (1949), 171.

(26) Clark et al.,: Med. Clin. Am. J., 35 (1951), 37.

(27) Allen \& Goodwiri: Radiology, 58 (1952), 68.

(28) Huff et al.: Persona? Communication.

(29) Yoshikawa et al.: Proc. Soc. Exp. Biol. Med., 49 (1942), 285.

(30) Johnston \& Lee: J. Am. Pharm. A., 32 (1943) 278.

(31) Pommerenke et aj.: Am. J. Obst. Gỹn., 46 (1943), 8ฐ̄3. 
すで汇敦用化されている。ての方法は, 電離函 あるいは G-M 管が遮蔽物を隔てつ線源の反對 側西って，放射線は直接には照射されないる らにして西る。同樣な考え方でパイプの厚さを 外から測定与るととも可能である。鋼管では $1.25 \mathrm{~cm}$. まで測れるから，化學工場なに゙の操業 中の配管の腐蝕狀況を檢查することもできる。 ての裝置は Penetron と稱して商品化されて いる(8)。

次にA. P. Schreiber は流體の比重測定にR.

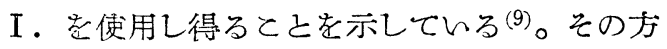
法注第 4 圖汇示すような簡單なものであって, 人絹製造のビスコーズの比重測定にすでに利用 され，更江自動制御子行っている。

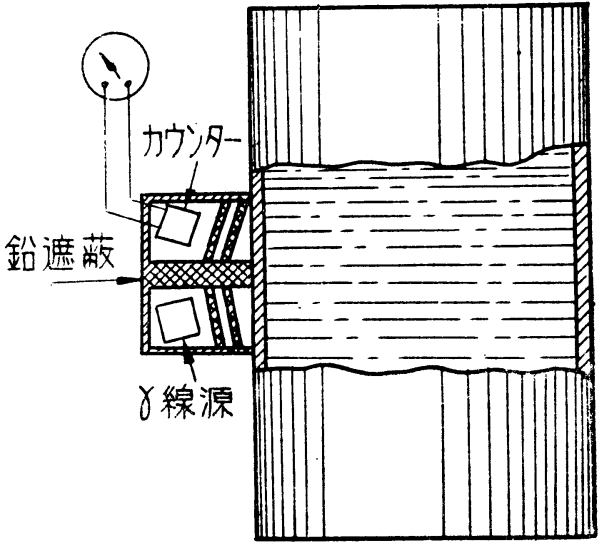

第 4 圖 散筒法による比重測定器

\section{8. 液面測定への利用}

タンクの形狀がに゙んなるのであっで外部か らの測定が可能であるから，化學工場などの高 壓タンクや液の粘性が高いものに適している。 cの装置に注 $\gamma$ 線源を用い万が, 線源が液面之 共に上下す多浮動式のもの之線源の固定式の \& のとがある。（第 5 圖）前者では液位と計數が 二次函數となるので線源之測定器が接近すると 感度住鈍人なる。同圖 (B) に示した固定式で は線源老幾つかタンクの周圄汇螺旋狀汇配置し て液位已計數か淔線關婇になるよ5に土夫され

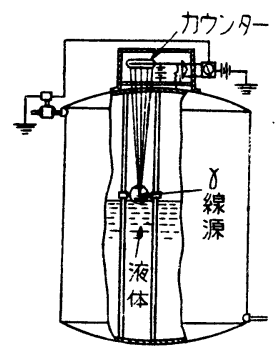

（A）線源浮動式

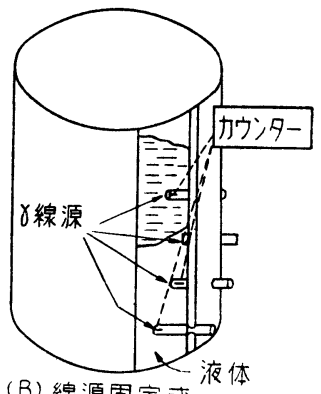

(B) 線源固定式
第 5 圖 液面測定器

它進步したものであって, Gagetron の商品名 で賽用化されている ${ }^{(10)}$ 。我が國でもすでに使 用している工場がある。

またキュポラの溶湯面の高さは從來全く測定 の方法がなく，全く經驗㑛賴ってい它のである が， $\mathrm{Co}^{60}$ をキょポの片側飞おを對側に G-M 管を設置しておくと，溶湯面の上昇により G-M 管の受けると線が急激汇減少するので容易に知 られる。勿論線源と G-M 管を同じレベルで上 下に移動可能にしておけば, 溶湯面を追跡でを て,キェポラの操業狀態をよく知るてとができ ろ。

\section{Tracer としての應用}

\section{Physical Tracer としての應用}

要すると物質の移動狀況を放射能を目じるし として追跡するてとであるが，ての用途ほ極め て廣い。ての方法で顯著な利縊をもをらしたる のは石油輸途についてである。はじめて Calfornia Research Corporation で同一の石油 輸揆管を使って2種類の石油を邆る場合に，石

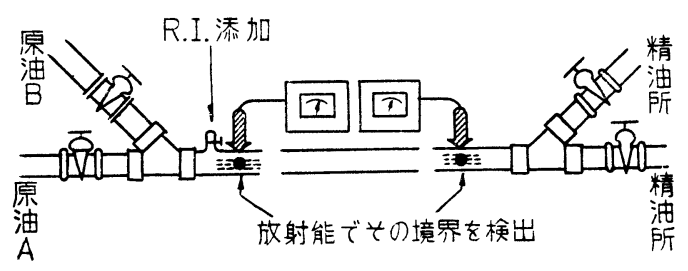

第6 圖 石油輸逵に用いられる Physical Tracer の例

(8) J. W. Jorvine: Analy. Chem., 21 (1949) 364.

(9) U. S. P. No. 2, 304, 910.

(10) U. S. P. No. 2, 565, 963. 
油の流れの境界點に R.I. 苞投大する方法を試 みて成功老收めた。（第 6 圖）

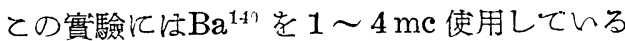
が, $\mathrm{Ba}^{140}$ ほ 12.8 日の牛減期で $1.05 \mathrm{Mev} の \beta$ 線と $0.5 \mathrm{Mev}$ の弱い $\gamma$ 線老放射して, $\mathrm{La}^{140}$ と 岁。 $\mathrm{La}^{1+10}$ ほ 40 時間の牛減期で $1.4 \mathrm{Mev}$ の 線乙 $1.64 \mathrm{Mev}$ の强い $\gamma$ 線之老放射して安定存 $\mathrm{Ce}^{140}$ となる。鐵製つ輸揆管外からの測定に注 $\mathrm{La}^{1100}$ の 線が有効なので西る。と秃らが貯藏 タンクに大っでる牛減期が短いから，精油所を 動く頃江注放射能孔衰元かつ稀釋もされるから 人體汇注全く無害で㐫る。

てれを离る距離の 2 點で測定すれば流體の流 動速度が測れるわけで市る。從って換氣つ場合 の氣流實驗にも氣體の R.I. さ元利用される。

土木工學で注河川や港灣汇於ける土石の移動 を調べことほ重要をととで，ての方面への應 用文我が國でる行わ机ている。CD目的汇注牛 減期の長いるのでなけ礼ば度らをいから $\mathrm{Co}^{60}$ が適している。まを油并つ地下つ流動狀況の調 查にも有効汇利用される。

鉛被電纜は地下に埋設されるが，鉛被汇避け 難い顯微鏡的ピンホールの爲に，水分が內部に 浸大し通信事故の原因之存る。ての缺陷笝所老 發見するとと经非常江困難教作業で㐫り，最近 てのためにガス體の R.I.をケーブルの一端から 壓力をかけて邆り达み，ピンホールの筒所から 漏洩与るR.I。の放射能を地上からカウンター で檢知する方法が行われている(11；。乙れ机用 レられるものはケーブルの構成物質と化學反應 を起さをい氣體で西るととが必要條件で市るの で, $\mathrm{C}^{*} \mathrm{O}, \mathrm{CH}_{3} \mathrm{Br}$ (氣化點 $4.6^{\circ} \mathrm{C}$ ), $\mathrm{Kr}^{\circ 5}$ ，疗 ぞが週したものである。

その他粉體の撒布狀沉の調查之力, 麗氣工學 汇於けるカソードの飛散現象の追跡存ぞ有効 である。

\section{2. 磨耗潤滑への應用}

との問題注 Physical Tracer ¿ Chemical
Tracer の兩方汇またがっている。摩擦磨耗機 構の研究住古くから行われていたととである が，R.I. の登場汇よって非常に銳敏な研究手 段となった。

B. W. Sakmann (12) らほ放射性の $\mathrm{Be}-\mathrm{Cu}$ 合 金の臺の上に金屬滑子をのせててすらせを後， 放射性物質が臺合金から滑子飞移る度合をG-M カウンターによって測定した。滑子に移る量は 荷重之運動距離に比例し，ての條件を一定にす ると，滑子が臺合金より硬い場合には表面粗度 飞依存するが，逆の場合飞柱存しない。滑子 を鐵なぼ沉かえてみをとてろ，滑子に移る金屬 の量は, $\mathrm{Be}-\mathrm{Cu}$ 合金の固溶度に比例する。亦 そ潤滑劑を使用した場合汇は放射能の移る度合 から荷重の小さい場合のみ有効飞作用りるが， 荷重が大をい場合にはなんら役をなさないと 注興味西ることである。

J. N. Gregory (13) は二つの金屬つ摩擦つ際 の附着狀態をオートラジオグラフによって研究 した。 $\mathrm{Pb}$ を $\mathrm{Pb}^{*}$ の上で滑らすと $\mathrm{Pb}$ の上には $\mathrm{Pb}^{*}$ が强く壓着され，それにつ和いて滑りが起 きている狀態の繰返しの連續である。潤滑劑を 用々る摩擦係數が減少するにつ秃て $\mathrm{Pb}^{*}$ の附 着量が減少している。潤滑劑は金屬間の粘着学 減少する江役立っているととが知れる。同樣汇 J. J. Burwell 注圆筒形の試料女用いて摩擦の

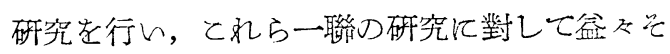
の確賽性を增した。G. L. Clark は潤滑劑つ作 用老放射性の油類によって研究した。こして實 用軸受合金の摩擦面上飞油の薄膜のでさるとと を示した。

內燃機關のピストンの既耗について, P.L. Pinotti (14) らは極めて簡易を方法さ行った。 即ちピストンリングを irradiate してピスト ン装着し，ピストンリングの磨耗狀態を潤滑油 の放射能測定によって研究した。ての場合トレ ーサーとなるR.I.ほFe"であって，12時間つ試 驗でリングの磨耗量を放射能測定から $24.6 \mathrm{mg}$

(11) I. E. Iohnston: Atomics, 2 (1951), 284.

(12) B. W. Sakmann: J. Applied Phys., 15 (1933), 469.

(13) J. N. GREGory : Nature, 117 (1945), 444.

(14) P. L. PinotTi: Petrolum Eng., 21 (1949). 
と算出しているが，てれは重量測定から出した 減量 $25.0 \mathrm{mg}$ とよく一致している。同時にシリ ンダー壁への R.I. の附着狀態をオートラジオ グラフによって撮影している。

J. T. Burwell (15) \& Cr*孛ピストンリング スメッキした場合の磨耗を調へてている。リング とシリンダーの磨耗がシリンダーの頭に於て著 しいてとを知った。また然料中に含まれる $\mathrm{S} の$ 磨耗に及㢳年影響子調べている。

\section{Chemical Tracer としての應用}

R. I. のとの方面への應用は，1913年と 1920 年に G. Hevesy らの行った三つの實驗から始 まったとんえよう。第一の賽驗ほ $\mathrm{PbSO}_{4}$ の水 溶液中の溶解度の測定孝老 $\mathrm{ThB}$ 用いて行った ものであり，その第二(17) $\left(\mathrm{No}_{3}\right)_{2}$ 一一放射性 $\mathrm{Pb}$ こしては $\mathrm{ThB}$ 老用いて レる一混合溶液についてイオン交換反應寊實 證して, Arrhenius の電離說を支持しをるの で㐫り，元の第三 ${ }^{(18)}$ ほやほり單體の $\mathrm{Pb}$ とThB を用いて溶融狀態に於ける $\mathrm{Pb}$ の自己控散を測 定しを實驗で西る。更に Hevesy は 1921年に ほ $\mathrm{Pb}$ こThB とよる固體の自己撗散を實驗して いる ${ }^{(19)}$ 。乙秃らの溶解度・交換反應・撺散质 ぞはR. I.の Chemical Tracer としての基本 的應用々いえよう。以後ての上万基礎的研究 は多くの人ふ汇よって行われ，人工R.I.が作 られてからは縊及盛になったので西る。工業的 應用としてはいきおい治金及び化學工業にその 例を多くみるのである。

\section{4. 治金工業への應用}

R. I. 研究方法の殆ざすへてが利用されてい る。

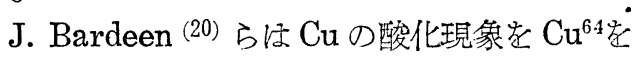
用いて研究した。 $\mathrm{Cu}$ の上に $\mathrm{Cu}^{*}$ 㠿メッし，

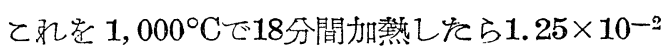

$\mathrm{cm}$ の酸化層を生じた。てれを燒入れて酸化層 を化學的に除去した後銅表面の放射能を測定し た。ての賔驗の結果, 銅の酸化ひ銅の結晶て格 子缺陷孛生するととによって內部淮行するて とがわかった。

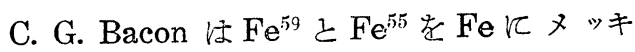
しを鐵試料を大氣中江放置しを後に，元の表面 に寫真乾板を密着させて露出を行った。大氣中 に放置した䴇に酸化した部分は，酸素の化合に より $\mathrm{Fe}^{*}$ の濃度が減少し，また放射線が酸化膜 に吸收される蘦に黑化度が弱くなる。てれによ って酸化物の生成が知られる己共に, 通常の方 法によって撮影したるのと比較すると全くよく 對照され, 可視光線による寫眞よりも正確に表 面現象老示すととがわかった。

E. S. Kopecki 注同樣汇 $\mathrm{Fe}^{59}$ 亿ょって鐵の 酸化皮膜中の擴散の機構について研究し，スケ 一ルの生成機構は複雜で西るとと孝述へてい

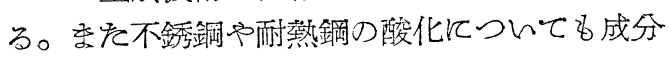
元素つ酸化狀態点調べている。

M. G. Fontana 注不銹鋼の不動態化の研究

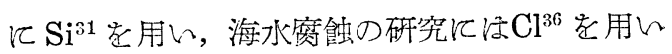
て行っている。

金屬の自己挰散の研究は前記 $\mathrm{Pb}$ の他飞 $\mathrm{Ag}$, $\mathrm{Cu}, \mathrm{Fe}, \mathrm{Cu}^{2} \mathrm{~S}$ 中の $\mathrm{S}$ などついて行われてい る。ま滲炭についても $\mathrm{C}^{14}$ 老用いた實驗が西 る。

Winkler こ Chipman ${ }^{(21)}$ 到 $\mathrm{P}^{32}$ 老用いて, 融鐵之鹽基性スラッグの間の平衡と於ける $\mathrm{P} の$ 分配の研究蓬行った。郎ち $\mathrm{P}^{32}$ 岩む $\mathrm{Ca}_{3}\left(\mathrm{P}^{*}\right.$ $\left.\mathrm{O}_{4}\right)_{2}$ 老融鐵に添加して, その時間の經過と之 もに融鐵とスラッグ中の放射能の比をトレーサ 一分析飞よって測定した。ての平衡は15分で達

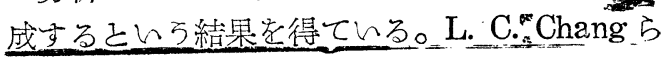

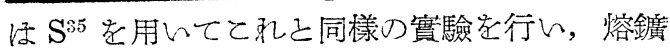

(15) J. T. BURWELL: Nucleon, 6 (1950), No.1, 34.

(16) G. Hevesy: Z. anorg. Chem., 82 (1913), 323.

(17) G. HevesY : Z. Elekrtochem., 26 (1920), 151, 363.

(18) G. HeVEsy: Ann. Physik, 63 (1920), 85.

(19) G. Hevesy: Ann. Physik, 4 (1921),65, 216.

(20) J. BARDEEN: Phys. Rev., 70 (1946), 105.

(21) T. B. Winkler, J. ChipmAn: Metals Technol., 13, No. 3 (1956). 
爐の脫硫機構の研究に有効な示唆を與えた。E. S. Kopecki は Ca ${ }^{45}$ に上化學分析また注分 光分析で不可能で西った $\mathrm{Fe}$ 中の $\mathrm{Ca}$ の溶解 度及び $\mathrm{Ca}-\mathrm{O}$ 平衡老決定した。更江彼らは $\mathrm{R}$.

I. を用いて簡易江蒸氣壓を測定して, 溶融スラ ッグ及び金屬中のいろいろの元素の活量を決定 乙ようとしている。J. K. Stanley ${ }^{(22)}$ 注 $\mathrm{P}^{32}$ 存 使って鹽基性平爐の脫燐過程老正確江把握し得 た。師ち $0.15 \mathrm{mc} /$ tonの $\mathrm{P}^{32}$ 左爐內に投大与 ると， $\mathrm{P}^{32}$ ほ急速にスラッグと溶鋼中に分散し て $\mathrm{P}$ こ $\mathrm{P}^{: 2}$ この比は一定となるので，その際の Pの含有量を定量しておく之，之の後は鋼中の

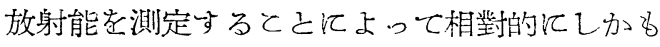
即時にPの含有量老決定できるので極めて便利 である。 $\mathrm{S}^{35}, \mathrm{C}^{1 \cdot 4}$ 沉つんても同樣のてとが可 能で两る。

合金學に對するオートラジオグラフほ極めて 有力な研究手段で亩る。顯微鏡で制別できない 組織內の現象をとらえるととができる。Silum$\mathrm{n}$ 合金中の $\mathrm{Na}$ の分布 ${ }^{(23)}$, 固溶體內の偏析存 ぞがその例で㐫る。オートラジオグラフによる 合金組織の研究应今日各方面で盛行われてい

變換, 郎ち $\mathrm{Cr}^{+3}$ と $\mathrm{Cr}^{+6}$ との間の變換孛同じ く容易化研究し得を。

R.I. 老用いるとガスの金屬中の擴散沉ついて も正確を結果が得られる。またガスの覔散速度 に上って子金屬の望性變形量も測定し得るとと が報告されている。

J. C. Harris ら任金屬加工用潤溫油飞可溶

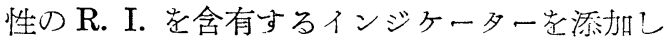
て，金屬の洗滌技術の研究老行っている。

鋼の溶接汇不純物こしての硫黄江有害で竕の て，てのために往々にして Sulphur crack と 稱する割れ老生和る。電孤溶接の場合溶接棒沉 $\mathrm{Na}_{2} \mathrm{SO}_{\mathbf{2}}$ 老溶劑乞して叙布して用い方。應和・ 加藤 ${ }^{24}$ ら注 $\mathrm{S}^{35}$ 孝用いて溶劑中の $\mathrm{S}$ 方溶接部 の金屬中に移行するかどらかを調へ，この平衡 には冷却速度が影響するてと老明力汇しで。郎

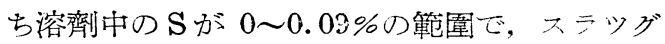

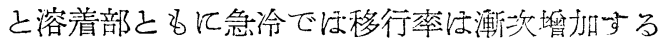

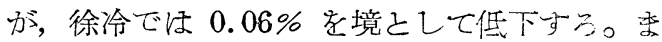
它氣化量注冷却速度の速く存万につ狄て減少す る。

る。 $\mathrm{Al}$ 合金や $\mathrm{Mg}$ 合 金港して中性于照 射老行った後汇オー トラジオグラフを行 ろのはよん存法で㐫 る。それは $\mathrm{Al}$ こ $\mathrm{Mg}$ 注數秒〜數分で原子 崩壤定終るから合金 成分だけ感光するて と机る。

F. Ogburn ら 站, Cr*炕ってCrメ” キ老行万際, $\mathrm{CrCl}_{3}$ が Cr の析出江與る こと仵知った。金屬 の原子價の同位元素
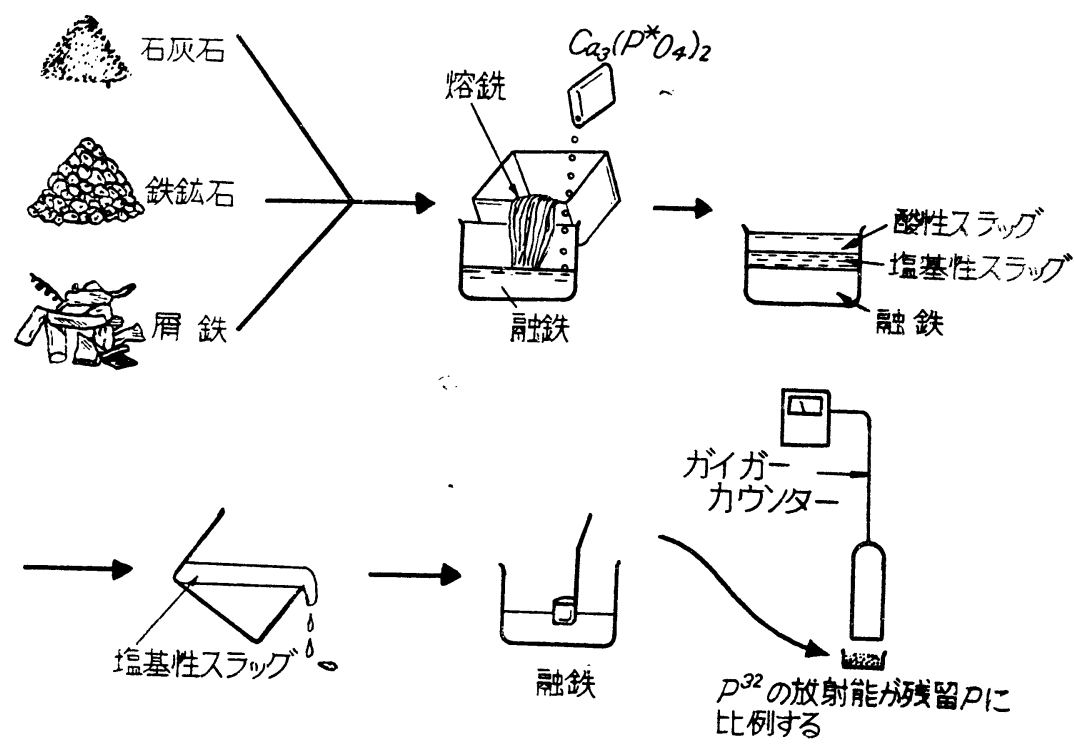

第 7 圖 $\mathrm{P}^{32}$ を製鋼の際の脫㷠反碓の檢定に利用する

(22) J. K. Stanley: Nucleon, 1 No. 2 (1947), 79.

(23) A. B. Michael, M. B. Bevev: J. Meta's, 5 (1953), 679.

(24) 隹和, 加藤 : 溶接學會誌， 21 (1952)，349. 


\section{5. 選籍への應用}

A. M. Gaudin ら注 R.I. 老利用乙て選擇附 着性の研究を行った。また彼は吸着劑が一般、 有機物質であるので， $\mathrm{C}^{14}$ 索用几て種及の研究 を行らととができ灾。H. J. Harwoodらも同じ く有機酸を用いで研究し, 吸着汇關する新しい 理論を導いた。T. G. Church ほ R. I. 老用い て浮游選鑛飞於ける鑛石表面の機構老研究し, 彼の發見しを方法汇よって，关机まで分離が困 難で西った二・三の鑛石の分離汇成功した。

\section{6. 化學工業への應用}

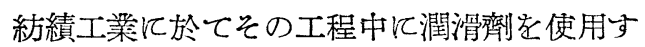
るが，ての系表面上の分布狀態老知るため 飞, J. W. Jrvine はォレイン酸ナトリゥム* $\left(\mathrm{Na}^{2-4}\right)$ 老潤滑劑として用い放射能測定によっ て調べを。A.P. Schreiber 恬染色機構につい て, 染料か吸收される位置や吸收された量をに゙ をR.I. 江よって功妙測定した。まを彼は人 絹製造に際して製品に殘留する微量のS 檢出 するのに $\mathrm{CS}_{2}$ *を使用するととを提唱した。人

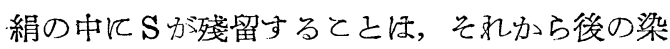
色之强度に有害である。故江 $\mathrm{CS}_{2}$ とセルローズ の反應で作られる人絹は, 必示脫硫機で殘留す るS 奎部落さなければなら学いが, 像め $\mathrm{CS}_{2}{ }^{*}$ 老添加しておくととによって脫硫度が容易に檢 查できる。

製紙工業に於てパルプ木材をダイジェストす る際に加えて必いて, 後の洗涤效率老放射能飞 よって簡單に知り得る。勿論ダイジェスターの 濃度子廢液子 R.I.汒よって制御できる。

B. Buchdahl は $\mathrm{P}^{32} \mathrm{Cl}_{5}$ を含んだインクや塗 料を用いて，その塗膜の狀態や厚さを放射能次 よって測定した。
J. K. Dixon ら䚾 R.I. 老水溶性表 面活性劑 の溶液之空氣の界面飞於ける吸着の研究飞役立 てた。との研究者達は $\mathrm{S}^{3 \overline{5}}$ の弱い $\beta$ 線の吸收を 有効飞使用した。その點では $\mathrm{C}^{14}, \mathrm{Ca}^{45}, \mathrm{Fe}^{59}$ b 可能である。

水溶液中の自己擴散は A. Gemant によって 研究された。

J. E. Willard ほ各種金屬の表面皮膜やメッ キの研究に，また金屬气の他の材質の洗滌の研 充に R.I. 老用いて有益を知識を得ている。

$\mathrm{Cr}$ ッキの場合の廢液中の $\mathrm{Cr}$ 药イオン交換樹 脂によって回收する際飞，その交換反應の飽和 點の檢知江 R. I. 老利用乙，かつ自動制御江上 りバルブの切換えを行っている。

J. J. Pescatore ほ塗料の付着性つ研巟江 Co" を含む樹脂を合成し，ビヒクルと混ぜてパネル 飞塗布し，曝露試驗後ブリスターを在じを部分 のパネル面に放射能が殘留しているかどらか子 測定して塗料とパネルの附着性を研究した。，

\section{7. 搳業ガラスエ業への應用}

ガラス狀組織沉つんての正確な知識活てれ李 で流分得られていないが，H．H. Blau ほ寫 県撮影の方法汇よってガラス中の $\mathrm{Na}^{2 \cdot 4}$ の擴散 速度の測定を行った。なおての方法注他の撗散 速度測定實驗に應用されるであらら。またガ

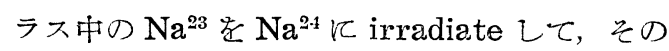
脫アルカリ現象老研究している。エマネーショ ン法にる R.I. 孛用いて效果を擧げている。

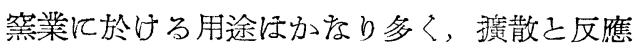
の研究, Se の蒸發の研究, 磁器の上江 $\mathrm{Au}$ p $\mathrm{Pt}$ を被覆する場合の厚さの測定，材料混合の研 究, 比重の自動調節, 爐の溫度調節の問題なぼ と今後要すす廣く應用されて行くであろら。 
第二日 ( 8 月 25 日) 午前

健康管理及び危險度の测定

1. 放射線障害

東大醫學部放射線科筧

弘・毅

2. Health Physics

3. 最大許容線量

4. 露出放射線量の測定

5. 放射性物質の防禦施設, 装置及び装具

6. 放射性物質の取扱心

7. 放射線障害の早期發見ととの對策

8. 參考文獻

（1）放射性同位元素安全取报法（譯）

Safe Handling of Radioactive Isotopes,

National Bureau of Standards, (1949)

（2）放射性同位元素と健康管理（筧）

Radioisotopes, Vol. 1. No. 1. (1952), p. 16〜27.

（3），放射性物質による陴害豫防勸告（案）

放射性物質に上る障害豫防勸告（案）

昭和 28 年 7 月 4 日

日本㗊學放射線學會

放射線障害豫防及び補償委員會

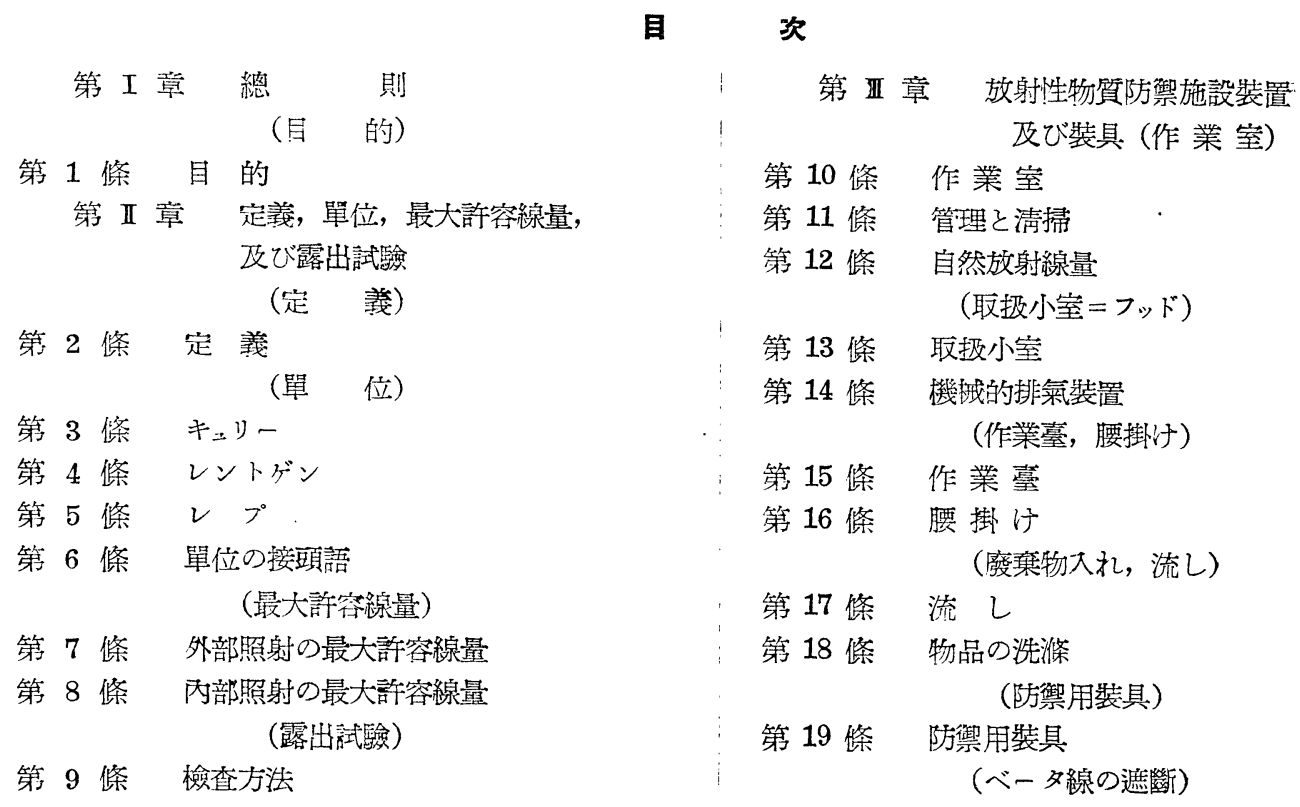


第 20 條

ベータ線の防禦

第 21 條

第 22 條

（咛藏，保管中止）

第 23 條 貯藏するときの防徱

第 24 條 聍藏用の安全容器

第 25 條

第 $\mathrm{N}$ 章 放射性物質の取扱い

$$
\text { (一般的事項) }
$$

$\begin{array}{ll}\text { 第 } 26 \text { 條 } & \text { 一般的注意 } \\ \text { 第 } 27 \text { 條 } & \text { 揭 示 } \\ \text { 第 } 28 \text { 條 } & \text { 澊守事項 } \\ \text { 第 } 29 \text { 條 } & \\ \text { 第 } 30 \text { 條 } & \text { 洗 滌 } \\ \text { 第 } 31 \text { 蓧 } & \text { ピペット操作 } \\ \text { 第 } 32 \text { 條 持込禁止品 } \\ \text { 第 } 33 \text { 條 } \\ \text { 出入のときの注意 } \\ \text { 第 } 34 \text { 條 } & \text { 持出品 }\end{array}$

(格納)

第 35 條＼cjkstart格 納

$$
\text { （淸 掃） }
$$

第 36 條 清 掃

$$
\text { (廢䢂物の處理) }
$$

第 37 條 橄害物の處理

第 38 條 污染物質の處理

第 39 條 放線性物質のこぼれ

(勞働持間)

第 40 條勞働時, 手洗の時間

$$
\text { （休暇） }
$$

第 41 條 休 㖊

第 $\mathrm{V}$ 章 ガンマ線の取扱い

$$
\text { (一般的事項) }
$$

第 42 條 ガンマ線の大量治療時の注意 （尷蔽物の厚さ）

第 43 條ガンマ線の防循物
（治 療 室）

第 44 條 ガンマ線治療室

(取扱い)

第 45 條 取扱い

第 46 條 安全容器加取出して和く時間

第 47 條 放射性物質を體內に留置している患者 の取扱い

（㜑搬）

第 48 條 運搬上の注意

$$
\text { （ガンマ線寫原撮影） }
$$

第 49 條 瑔備望驗

第 50 條工場または事業場のガンマ線寫复撮影

第 51 條ガンマ線源としてのラドンの取扱い

第 VI 章 筐康診斷

(一般的事項)

第 52 蓧定期箻康診断

第 53 條 取扱者の䛦斷

第 54 條 定期血液檢查

第 55 條 未梢血液障害

（體內に殘留する放射性物質の線量）

第 56 條體內に殘留する放射性物質の測定 (健康診斷記錄表)

第 57 條 健康診斷記錄表

第 UII 章 放射性物質による障害とそ

の應甞處置

(危險 度)

第 58 條體內に取り入れられた放射性问位元素 の危險度

第 59 條體內に最大許容線量以上殘留せる者の職 場轉換

第 60 條 仵業中の創傷

第 61 條 誤って飲几だ場合

\section{放射性物質に上了障害防止勸告}

第 I 章 總則

$$
\text { （目的） }
$$

第 1 條 本勸告ほ放射性物質の取扱（保管，運 搬, 使用, 消費, 廢集店ぼ) を規制し, 放射 線による人體委で物品飞對する障害を防止 するよら勸告するのを目的とする。

第 II 章 定義，單位，最大許容線量
及び露出試驗

$$
\text { （定義） }
$$

第 2 條 放射性物質とほ放射性元素, 放射性同 位元素及びそ礼らの化合物又注加工品をい 万。

第3 條 本勸告でいら放射線と注ェックス線, ガンマ線及びベー多線をいい，エックス線並 
びにガンマ線注 $3 \mathrm{MeV}$ 以下の量子エネルギ 一つる心皆對象上する。

$$
\text { (單位) }
$$

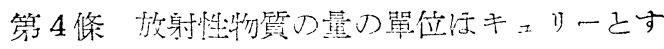
る。キ土リ一海每秒 $3.700 \times 10^{11}$ D原子崩壞

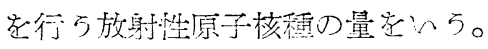

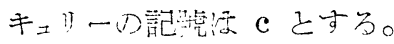

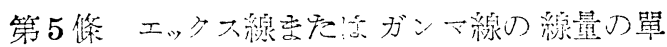
位行レントゲンとする。レントダンはエック 大線又はガンマ線の照射汇上り，影煤空氣 0.001293 グラムでとに放出される柆子をし

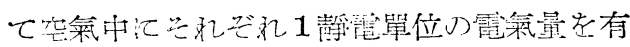

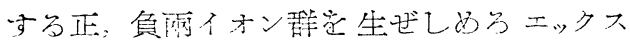

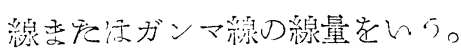

レントゲンの記躆は $\mathrm{x}$ とする。

第6 條 エックス線又注ガンマ線以外つ技射線 の線量つ繁位标レプとする。

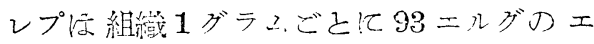

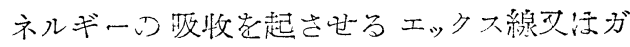
ンマ線以外の放射線の線量岂いら。

レプの記踖河 rep とする。

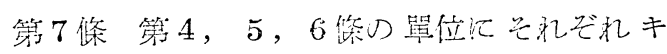

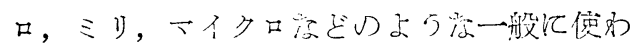

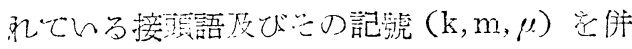
用するととタ゚゙る。

\section{（最大許容線量）}

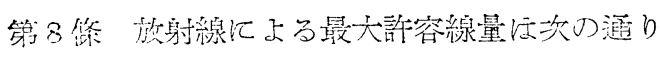
と市方。

\section{(1) 坴身露出}

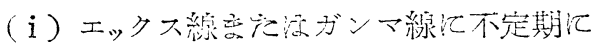

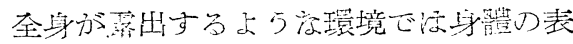

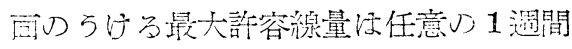
化つき 0.5 ×さする。

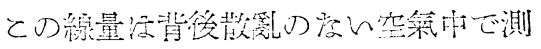

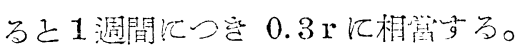
(ii) 高エネルギー, ベー夕線の場合の身體 表圂にうけ万最大許容線量注，任意》1 淍間につを硬ガンマ線量 $1.5 \mathrm{r}$ 方基底尿

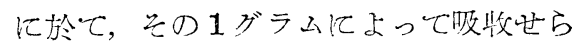

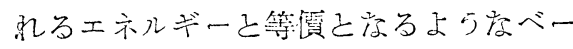
夕線量とする。

との線量应 1 淍間につき約 $1.5 \mathrm{rep}$ 亿
谓堂正方。

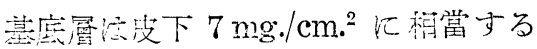
深さ汇存在するもの上徦定する。

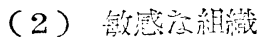

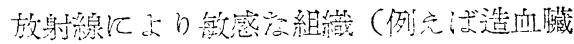

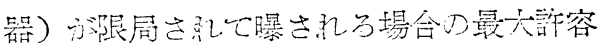

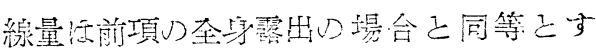
万。

\section{(3) 部分露出}

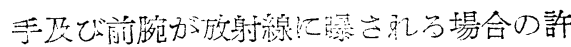
容線量河，基底層江於へて任意り 1 週間に

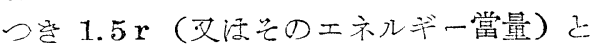
方。

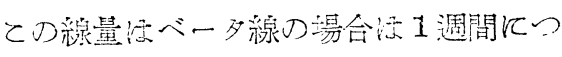

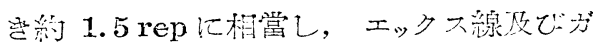

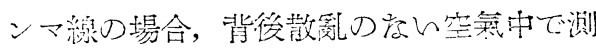
る己 1 淍間につ登 $1 \mathrm{r}$ 沉相當与方。

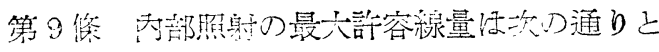
方后。

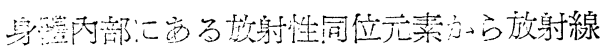

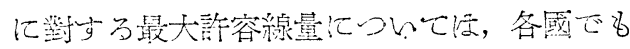

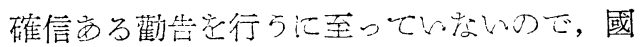
際放射線防護委員會 ( 1950 年7月)方採用し

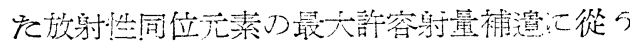

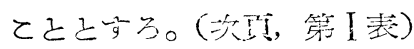
(露 出䟼频)

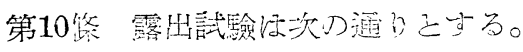

（1）放射線汅贯出し易い取投者にフィム・

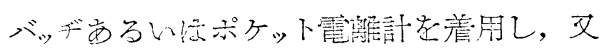

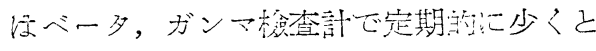

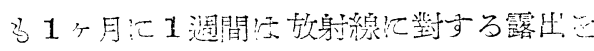

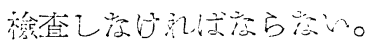

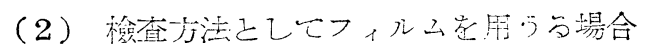
注，ベータ線茂びガン、線の量を區分して

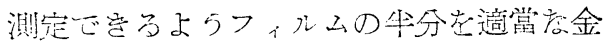

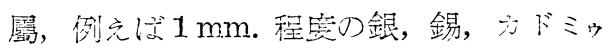

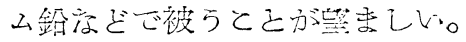

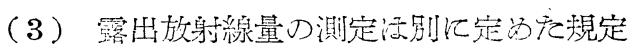

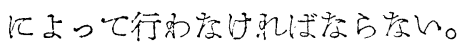

第自章 放射性物質防徛拈設灭び 琵置と关礼らの整備 (作 業 空) 
第 I 表 放射性同位元素の最大許客線量補遗

\begin{tabular}{|c|c|c|c|c|c|c|c|c|c|c|c|}
\hline $\begin{array}{l}\text { 放射性间位元素 } \\
\text { 許 容線 量 }\end{array}$ & $\mathrm{R}^{22 j}$ & $\mathrm{P}_{i \mathrm{i}}^{233}$ & $\mathrm{Sr}^{8.3}$ & $\operatorname{Sr}^{9 ?}(+\mathrm{Y})^{911}$ & $\mathrm{P}_{\mathrm{o}}^{210}$ & $\mathrm{H}^{3}$ & 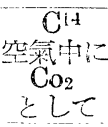 & $\mathrm{Na}^{2 !}$ & $\stackrel{32}{\mathrm{P}}$ & $\stackrel{6.0}{\mathrm{C}}$ & $I^{1 / 1}$ \\
\hline $\begin{array}{l}\text { 體內に於ける最大煲 } \\
\text { 容水準 }(\mu \mathrm{c})\end{array}$ & 0.1 & 0.04 & 2.0 & 1.0 & 0.005 & $1 \times 10$ & - & 15 & 10 & 1 & $\begin{array}{c}0.3 \\
(\text { (田狀踩㠳では } \\
0.18)\end{array}$ \\
\hline 堛效平均囊命 (日) & $10^{4}$ & $10^{4}$ & - & 5,000 & - & 10 & - & 0.8 & 20 & 23 & 12 \\
\hline 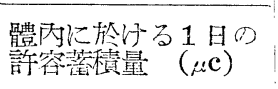 & $10^{-5}$ & $4 \times 10^{-5}$ & - & $2 \times 10^{-1}$ & - & $1 \times 10^{3}$ & - & 20 & 0.5 & 0.05 & 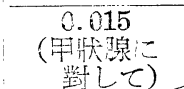 \\
\hline 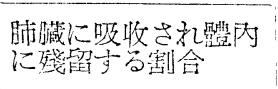 & 0.06 & 0.1 & - & 0.06 & - & 1 & - & - & - & - & 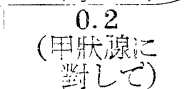 \\
\hline 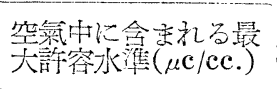 & $8: 1^{-12}$ & $2 \times 10$ & - & $2 \times 10$ & - & $5 \times 10^{-5}$ & $1 \times 10^{-3}$ & - & - & - & $3 \cdot 10$ \\
\hline 腸に殘留 & 0.1 & 0.001 & - & 0.1 & - & 1 & - & 1 & 1 & 1 & 0.2 \\
\hline 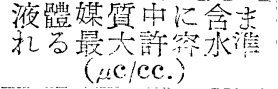 & $4 \times 10^{-9}$ & $1.5: 1^{-9}$ & - & $8 \times 10^{-7}$ & - & 0.4 & - & $8<1^{-3}$ & $2 \times 10^{-4}$ & $1 \times 10^{-5}$ & $3 \times 10^{-5}$ \\
\hline
\end{tabular}

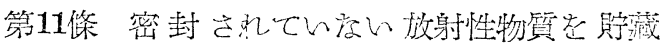

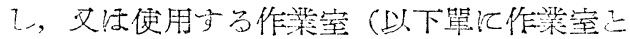

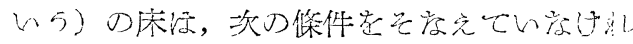
ば等方学的。

（1）些淂で不淬透性材料で作ら京ていると 之。

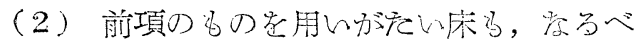
く平滑で, 不㳙透性材料で完古飞被らとと。

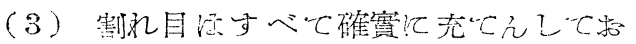
くc之。

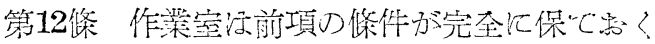

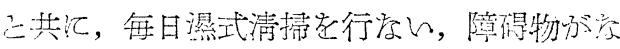

い上の管理しをければ虔ら存い。

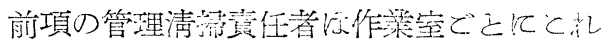
在定市。

第13悠

（1）作業宝內刀放射性污染蓄（Back一 ground radiation) 情最大許容線量つ 10

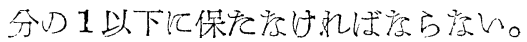

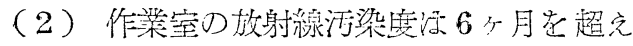

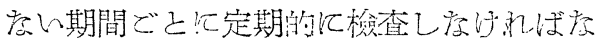
ら等的。

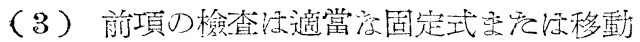

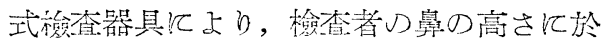

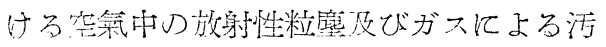

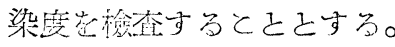

（取报小社=フッド）

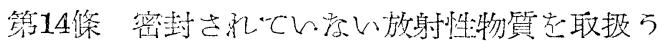

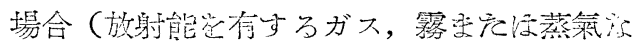

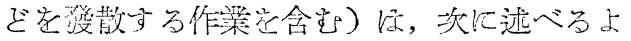

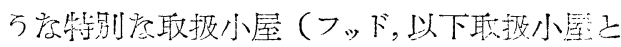

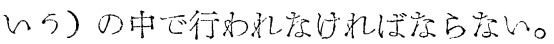

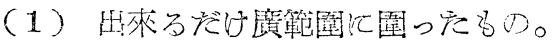

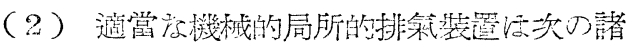

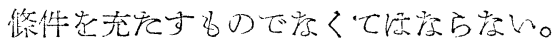

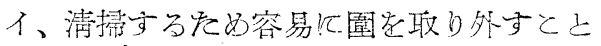
が出來るもので京るとと。

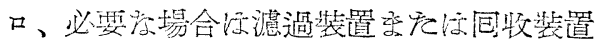

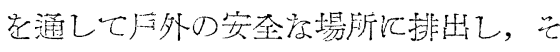

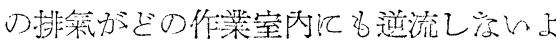

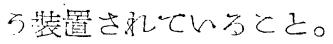

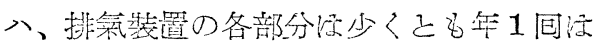

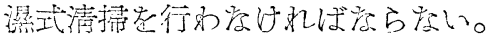

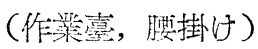

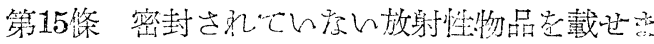

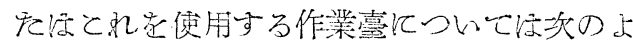
厅行定める。

（1）各人につん幅 $1 \mathrm{~m}$. 以上奧行 $50 \mathrm{~cm}$. 以上で西るこ之。

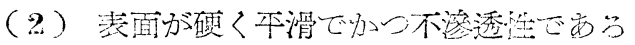


乙と。

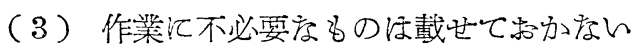
c之。

(4) 毎日濕式清擩觉行らとと。

（5）鉗子气の他の工其圆置くめ，容易汇 清掃出來る工具掛离た㳊置臺它設けると と。

第16條 密封されてい度い放射性物質を取报万 ものの腰掛けほ，表面が平滑で㐫って毎日て れを瀿式清掃するとと。

（廢彗物大れ，流し）

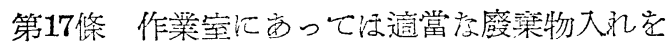
備充，放射性物質汇上り污染せら礼をるの字

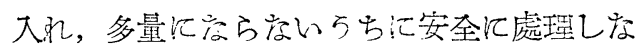
ければなら宗い。

第18條 作業室比不渗透性物質で作った流し を備充，放射性物質心污染せられた物品を充

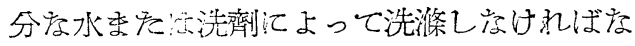
方度的。

(防㛃用裝具)

第19店 密閉されてい学い放射性物質の取报者 もしく浪とれらの物質の貯藏至, 作業場で清 掃儿從亨するもののために别汇定める規格に 遮合しを保蒦衣，帽子，胸當萧用の防水前掛 け,ゴム手琴，保護眼鏡放ぎを備えつけ，取

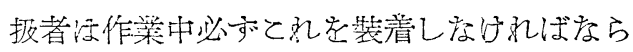
ない。

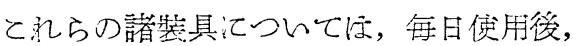
放射性物質により污染されているかどらかを 檢查するととが望要しん。

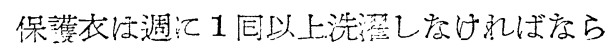
ない。

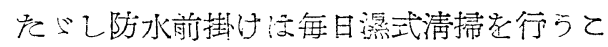
之。

$$
\text { (ベータ線つ遮比) }
$$

第20条 ベータ線学放射する物質を使用する場 合，その放射線它遮斷する必要の西るときほ 次江掍げる第II表による。

最大エネルギーE MEVD $\beta$ 線岂完全化防 ぐ汇必要之さ就方代表的物質の厚さ $\mathrm{Tm} \cdot \mathrm{m}$ 第21策 ベー夕線它放射する物質力ら主として

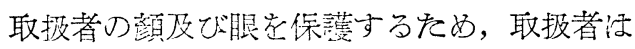

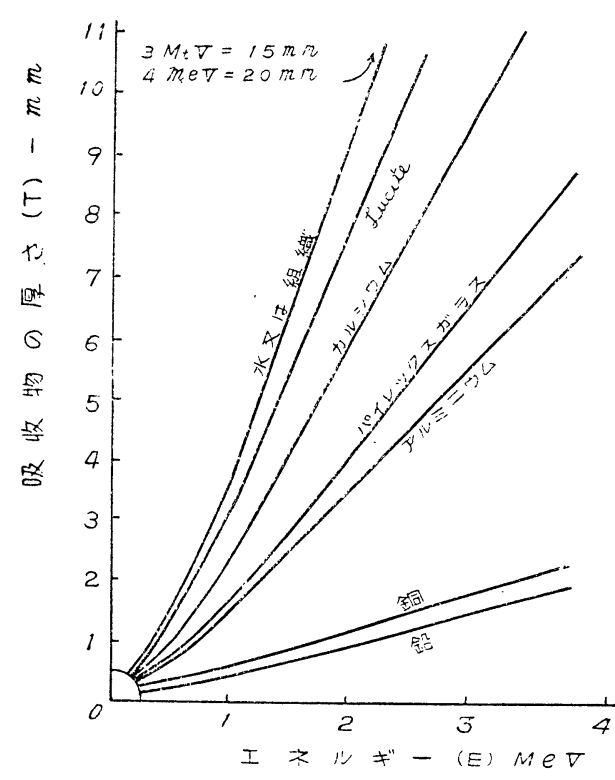

第 II 表 ベータ線の慧斷

調節できるガラス製遮薇板を娔用しなけ机ば ならない。

2. 前項の遮蔽板を便用するとこの出來をい 場合に注，保護眼鏡索裝用しなければなら 度的。

第22條 放射防護に用いるすべての施設及び裝 具浪その目的汇適應したるのでなければなら 究的。

2.乙礼らのもの主良好度狀態江西り，かつ 满足㣫作しているかどらかを物定するた めに，3ヶ月に 1 回專門家の檢査索受けな ければならなん。

3.も乙檢查の結果何らかの缺陷を發見した とさな，速力炕是正票它泟修理しなければ ならない。

（貯藏，保管中止）

第23條 放射性物質に對する防護用遮䕐物仿で

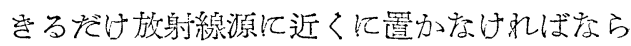
李い。

第24條 使用していない放射性物質々貼藏用の 安全容器キャビネットまを江夫夫室の中に入 れ，錠を掛けておかなければならない。 
2. 安全容器汪次の各號に上らをけ机ばをら 店的。

イ、作業場から出來る限り離して㤁くこと。 口、置く位置 及び 貯藏する放射性物質の量 汇應じ，定めら礼を厚さの防護索用いる ¿と。

3. 貯藏して西方放射性物質が放射性索有す ろガスまたは蒸氣を發散し易いるのである 場合注，安全容器老開人前少くとb5 分以 上機栈的度方法で大氣中有效江換氣し学 ければ学らない。

第25條 密封さ礼ない放射性物質老保管又住使 用しをとをほ，次の各號つ措置家譵市るまで， その空它他の用途に使用しては䄈らな。

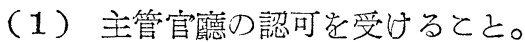

（2）作㮍室及び その室內江置いて西る什

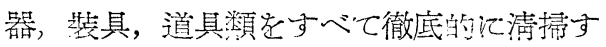
るとと。

第 IV 章 放射性物質の取报い （一般的注意專項）

第26佟 放射性物質の取报者 (以下單汇取技者 という）は，放射線障害についての知識安有 し, 細心の注意を拂ってなるへく安全汉㠷

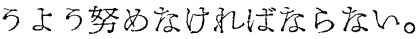

第27集 放射性物質取报作栄場汇经, 必要孝注 意事項学見易い所汇揭示しなければを方存 几。例元代注意! 放射性同位元素之朱書学与 るととも必要で亦る。

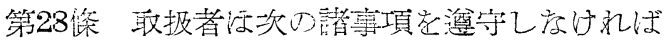
疗方究い。

（1）作栄汇必要度最少量老取报らこ己。

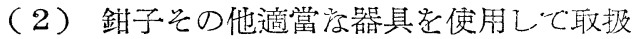
ん，手及び身體を存るべ遠避けるとと。

(3) 放射性物質の近くにい万時間怔, 作業 江必要䒚短時間上すると之。

（4）取报者の便用汇當てるをめ, 適當を維 整ハンカチを備え他のハンカチ它使用してて ほをらない。

（5）便用濟多の紙製ハンカチは, 備付けの

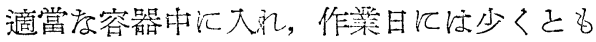

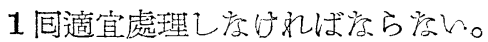

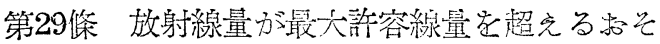

れの亦る場合ほ別汇定める規格几適合して防

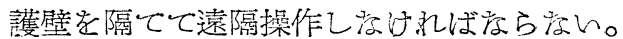

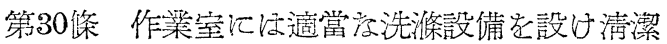
存手拭及びブラシ它㒂光, 手指, 前腕なぞ徹 底的汇清掃しなけ礼ば索ら学ん。

第31條 放射性を有する溶液のピペッ下操作任 ロで行ってねならない。

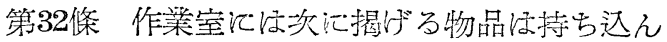
で度らない。

(1) 飲食物及び食器

（2）煙草及び契陻具

（3） ハンドバッグ，化粰品及で化粈道具

(4) ハンカテ

（5）气の他不必雬疗物品

第33條 放射性物質の取预者玉住作葙至の清

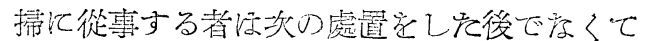
注, 飲食, 契煙, 化粧, 用便委を海外出しで 存症放教。

（1）保蒦衣及び紙製ハンカチ丧所定の場所

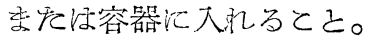

（2）手及び前腕是洗い，爪老清潔汇すると 之。

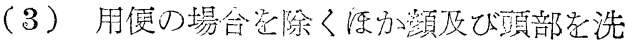
$5 \succeq$ こ。

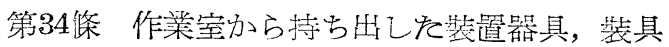
ケすべて徹底的汇清禘しない限り，外部汇持

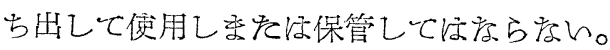

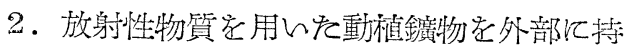

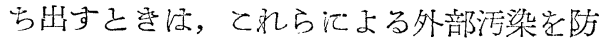

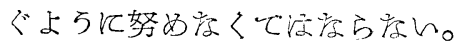

(格 納)

節35條 放射性物質老連日便用する場合老除を

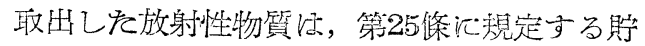
藏容器中に作策終了後保管する。

（清

掃)

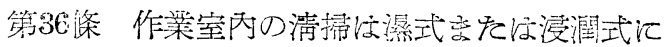
上り行ん, 清掃用のブラシ長树雜布, 存切れ, 攻びその他の用器の取报いは次の定的汇よ る。

（1）他の用途江用いたいとよ。

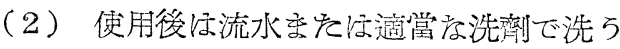
cと。 


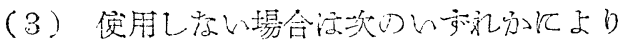
保管要方公已。

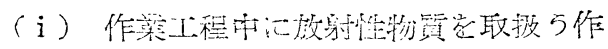
葓場

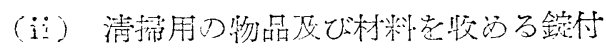

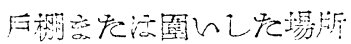

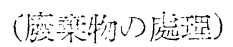

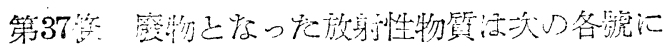

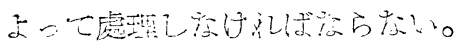

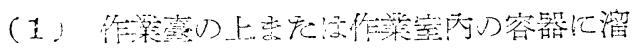

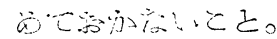

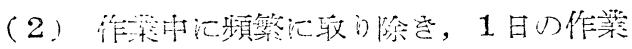

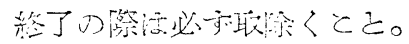

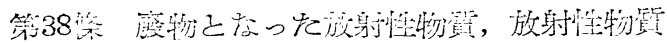

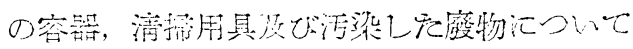

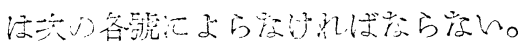

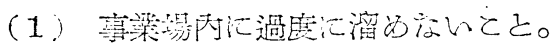

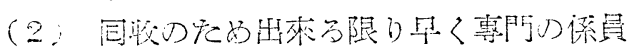
に息すとと。

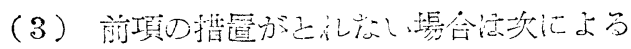

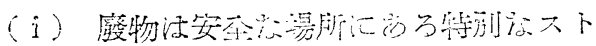
ーブで㹰却するここ。

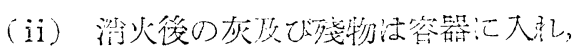

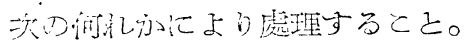

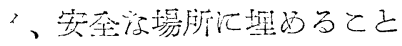

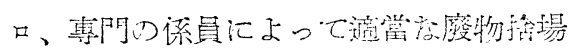
汇侩てらこ之。

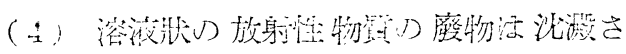

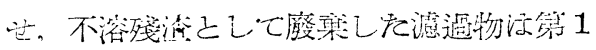

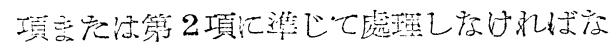
ら察い。キがしてれが不可能度場合汇注溶

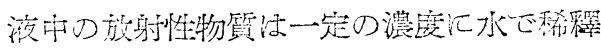

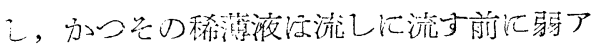
ルカリ性にし，かつ旅しを後は多量の水だ 上く洗い流さ称ば学ら学い。

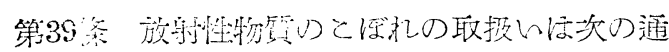
りさする。

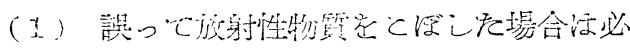

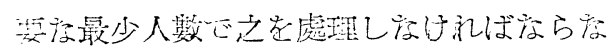
no

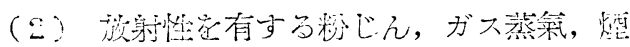

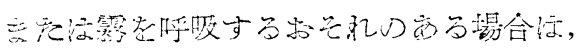

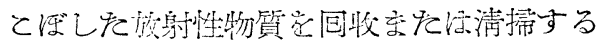

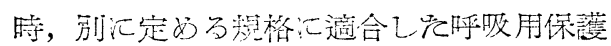

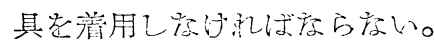

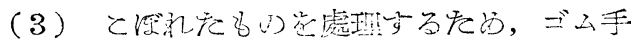

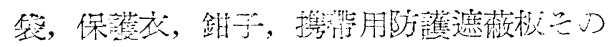

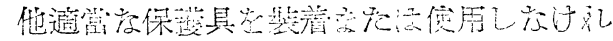
ば六宗い。

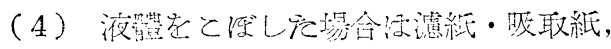

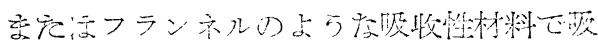

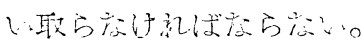

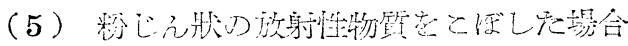

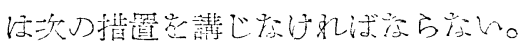

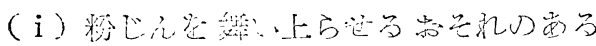

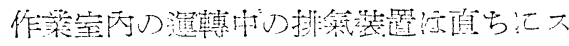

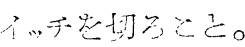

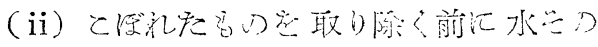

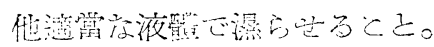

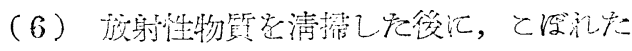

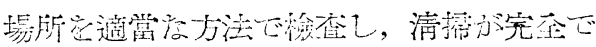

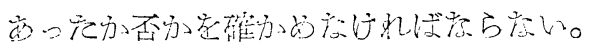

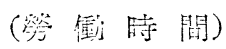

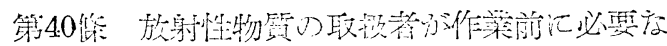

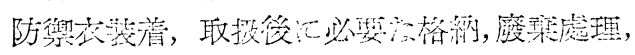

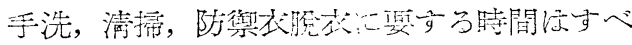

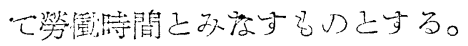

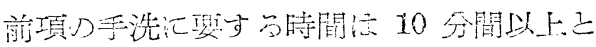

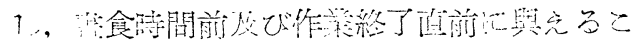
¿上ษュ。
(林:
调)

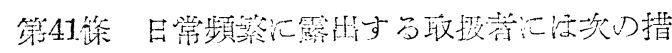

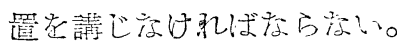

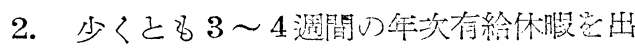

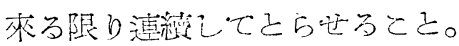

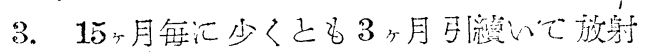

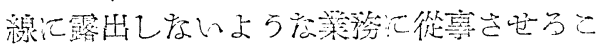
と。

\section{第り章 ガンマ線の取抖}

\section{(一般的玨)}

第42焦 ガンマ線の犬線量空佼用する場合

(Multicurie source) 汸，特汇气の防珤:

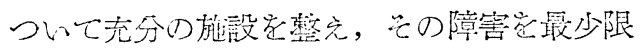

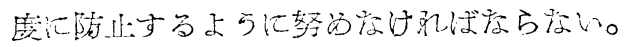


（遮蔽物の厚さ）

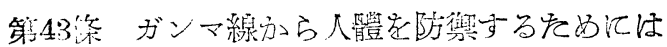

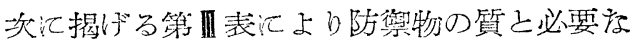
厚さ老定める。

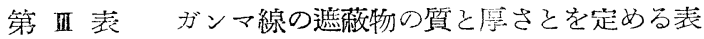

\begin{tabular}{|c|c|c|c|c|c|c|c|c|c|}
\hline \multirow{2}{*}{ 放 射 能 } & \multicolumn{3}{|r|}{ 工 } & ネ $ル$ & \multirow{2}{*}{$\begin{array}{r}キ ゙ \\
1.5\end{array}$} & \multicolumn{2}{|c|}{$-\quad(\mathrm{MeV})$} & \multirow[b]{2}{*}{3.0} & \multirow[b]{2}{*}{4.0} \\
\hline & 0.2 & 0.5 & 0.8 & 1.0 & & 2.0 & 2.5 & & \\
\hline $10 \mathrm{mc}$ & -0.14 & -0.35 & -0.27 & -0.11 & +0.37 & +0.78 & +1.15 & +1.40 & +1.70 \\
\hline $20 \mathrm{me}$ & -0.09 & 0.00 & -0.41 & +0.76 & +1.57 & +2.16 & +2.63 & +2.91 & +3.21 \\
\hline $50 \mathrm{mc}$ & -0.01 & +0.47 & $\div 1.31$ & $+1 . c 0$ & +3.15 & $\therefore 4.00$ & +4.57 & +4.80 & +5.20 \\
\hline $100 \mathrm{mc}$ & +0.06 & $\therefore 0.82$ & +1.89 & $\div 2.77$ & +4.34 & $\div 5.38$ & +6.06 & +6.41 & +6.71 \\
\hline $200 \mathrm{mc}$ & +0.10 & +1.17 & +2.67 & +3.63 & $\div 5.54$ & $\therefore 6.77$ & +7.52 & +7.92 & +8.21 \\
\hline $5 \mathrm{comc}$ & +0.17 & $\div 1.64$ & +3.57 & +4.78 & +7.12 & $\div 8.60$ & +9.47 & +9.91 & $\div 10.21$ \\
\hline $1 \mathrm{c}$ & +0.23 & +1.99 & +4.25 & +5.65 & +8.31 & +9.99 & +10.95 & +11.41 & +11.71 \\
\hline $2 e$ & +0.28 & +2.35 & $\div 4.93$ & +6.52 & +9.51 & +11.37 & +12.42 & +12.92 & +13.22 \\
\hline $5 c$ & +0.33 & +2.81 & +5.82 & +7.66 & +11.09 & +13.21 & +14.37 & +14.91 & +15.21 \\
\hline $10 \mathrm{c}$ & +0.41 & $\div 3.17$ & $\div 6.50$ & +8.52 & +12.28 & +14.59 & +15.85 & +16.42 & +16.72 \\
\hline $20 \mathrm{c}$ & +0.47 & $\div 3.52$ & +7.18 & +9.39 & +13.48 & -15.98 & -17.32 & +17.83 & +18.23 \\
\hline $50 \mathrm{c}$ & +0.54 & +3.99 & +8.08 & +10.54 & +15.06 & -17.81 & +19.27 & +10.92 & -20.22 \\
\hline $100 \mathrm{c}$ & +0.60 & +4.34 & $\therefore 8.76$ & +11.40 & +16.25 & 19.20 & +20.75 & +21.43 & $\therefore 21.72$ \\
\hline 危嗡距離 & Jj $(+)$ & jili & join & 加 & 加 & jill & Jil & 形 & 斺 \\
\hline $20 \mathrm{~cm}$ & +0.26 & -1.64 & $\div 3.16$ & +4.02 & +5.55 & +6.44 & +6.85 & +7.00 & +7.00 \\
\hline $50 \mathrm{~cm}$ & +0.11 & +0.71 & +1.36 & +1.73 & +2.39 & +2.77 & +2.85 & +3.01 & +3.01 \\
\hline $1 \mathrm{~m}$ & 0.00 & 0.00 & 0.00 & 0.00 & 0.00 & 0.00 & 0.00 & 0.00 & 0.00 \\
\hline $2 \mathrm{~m}$ & -0.11 & -0.71 & -1.38 & -1.73 & -2.39 & -2.77 & -2.95 & -3.01 & -3.01 \\
\hline $5 \mathrm{~m}$ & -0.26 & $-1 . £ 4$ & -3.16 & -4.02 & -5.55 & -6.44 & -6.85 & -7.00 & -7.00 \\
\hline $10 \mathrm{~m}$ & -0.37 & -2.35 & -4.52 & -5.76 & -7.94 & --9.21 & -9.80 & -10.01 & -10.01 \\
\hline 作業時䦭 & $\mathrm{jon}_{\mathrm{n}}(+)$ & 踏 & 加 & 加 & 嫣 & 施 & H & 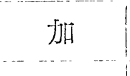 & Hit \\
\hline 1 & -0.17 & -1.06 & -2.04 & -2.60 & -3.53 & $\cdots 4.16$ & -4.42 & -4.52 & $-\quad 4.52$ \\
\hline 2 & -0.11 & -0.71 & -1.35 & -1.73 & -2.39 & $\cdots 2.77$ & -2.85 & -3.01 & -3.01 \\
\hline 4 & -0.06 & -0.35 & -0.68 & -0.87 & -1.20 & $\therefore 1.39$ & -1.47 & -1.51 & -1.51 \\
\hline 8 & 0.00 & 0.00 & $0 . C 0$ & 0.00 & 0.00 & 0.00 & 0.00 & 0.00 & 0.00 \\
\hline 24 & +0.09 & +0.56 & +1.08 & +1.37 & +1.89 & $\div 2.20$ & +2.34 & +2.39 & +2.39 \\
\hline 吸 收 物 & 票 (x) & 恋 & 涪 & 乘 & 耕 & 乘 & 䒠 & 澅 & 溗 \\
\hline $\mathrm{Pb}$ & 1.00 & 1.00 & $1 . C 0$ & 1.00 & 1.00 & 1.00 & 1.00 & 1.00 & 1.00 \\
\hline $\mathrm{Fe}$ & 8.80 & 2.88 & 1.96 & 1.74 & 1.49 & 1.43 & 1.47 & 1.48 & 1.59 \\
\hline $\mathrm{Ail}^{\mathrm{H}}$ & 41.67 & 9.80 & 6.18 & 5.33 & 4.83 & 5.00 & 5.28 & 5.68 & 6.39 \\
\hline $\mathrm{H}_{2} \mathrm{O}$ & 103.84 & 21.54 & 13.42 & 11.59 & 10.33 & 11.11 & 11.19 & 12.11 & 12.78 \\
\hline
\end{tabular}

1.・又流コンタリート

注意

（1）放射源の放射能（Source activity）はミリキュリー或はキュリー單位で啊ばれる。その

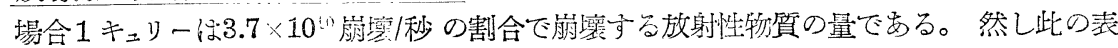
の各崩壤は离るきまったエネルギーの1つの $\gamma$ 光量子を生ずるという更にるうけて假定 
の下で計算されて居る。此の數岕崩壤が複雜である時は常に不正確なる結果を生ずる。 一層正確なる計算は崩壞方式が知られている時よく知られた方法によって行うことが出 來る。

（2）此の表は幅の廣い放射線照射（Wide beam irradiation）の場合遮蔽物に上り墧加した 實際の透過 (Increased effective transmission) を無視した。

（3）逘蔽の表の形式 (C.C.Gamertsfielder の作った) は實驗室に於ける一時的遮蔽を急い

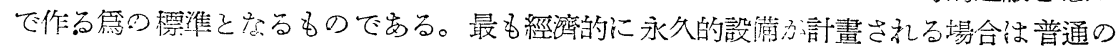
方法によって，より精密に計算するここが必要で岁る。

2. 前項の規定は照射用のボンベ庈び遮蔽 物, 貯藏容器の遮蔽化適用するものとする。

$$
\text { （治 嚓 㗌） }
$$

第44條 ガンマ線治療室の防禦汇ついてけ次の 諸條件を備えをるのであることが旺ましい。

（I）鐵筋コンクリート作りで西って，窒の 廣さほ $4 \mathrm{~m}$. 四方以上で天井の高さは $3 \mathrm{~m}$. 以上で西るて之。

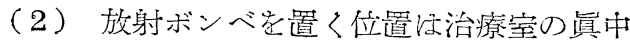

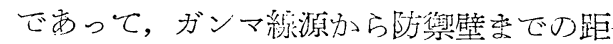

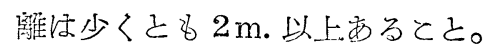

（3）四方の防眎壁及び天茾の防酎物の質己 乞の厚さにつん゙C症，前第43條の規定汇準 據し, 治療室以外の場所で最大許容線量葆 超元ては度らない

（4）照射時沉房，利用線錐つ方向は人がい 度い屋外かまを地下の方向汇向いている c之。

（5）ガンマ線治療中注, 患者以外は絕對江 治療室飞溜ってほならをい。をがし，照射 ボンべを“断”（off）の位置汇したとを並 び汇放射性物質をボンベ汇答置する場合は ての限りで度い。

$$
\text { (取报) }
$$

第45集 ガンマ線治療饮原則として遠隔操作

（Remote Controle）汇よb，充分汇防禦安

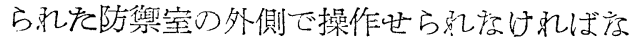
方福。

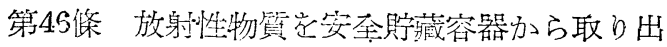
して心く時間は，出來る短くし，力口照

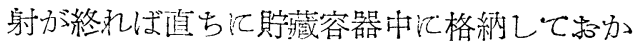
度ければ虔らない。

（2）前項の放射性物質の出乙大れ桠，特製 の把持器 (Holder) に象じ汉むよ5に出來
ている長い棒が使える構造で度ければをら ない。

第47條 放射性物質に上り治療中の患者芝收容

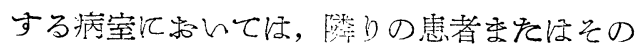

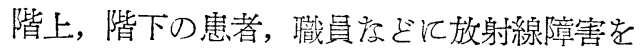

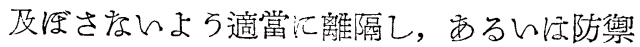
物を臨時汇置くなぞの虎置をする。たがし放 射線量が極めて微弱で甚しい障害に及虔さな んと豫め推定せら礼る場合はこの限りでな w。

（運搬）

第48條 ガンマ線它放射する物質の輸送運搬注 原則と乙て第血表江規定する防棒物容器內汇 大れをる喗搬するものとする。

2. 前項の場合, 外包汇「注意! 放射性物 筫！」と明記する兄のとする。

（ガンマ線鷽畺撮影）

第49焂 放射性物質飞るり竄県撮影 (Radio-

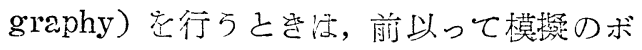
ンベまをほカプセルなぎ方便用して豫備實驗 它行らことが望むしい。

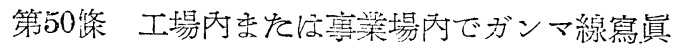

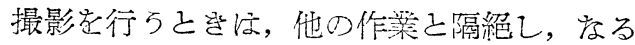
へくすべての從業員衣放射線源から $10 \mathrm{~m}$. 以 上遠避けるよう江努める。

第51條 ガンマ線源としてラドンの漏洩するお 乞れの无るもの老取披う場合は，乞の撮影ま を注便用汇あをり气の場所它滴當な方法で換 氣しをければなら度ん。

（2）ガンマ線撮影汇ピッ下炎使用する場合 も委た前項江準和る。

（3）た心゙し, 自然掺氮强く放置するる安全 で㐫る己認められる場合は，ての限りでな h。 
第们章 健 康 診 斷

(一般的芧項)

第52條 放射性物筫の取披者社定期健康診斷老 少くとも年 2 国行らとととする。

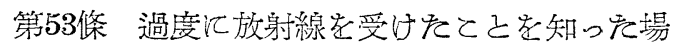

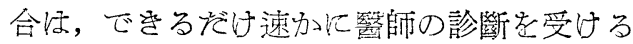
当のとする。

(血液 檢 查)

第54條 放射線汇露出する作業索始める前及び 從業中，年 2 国以上熟練した篦師沉つんて血 液檢查在受けるものとする。

(2) 前項の血液檢查の內容洁, 血色素量, 赤血球數, 白血球數及び白血球百分率こし
て必要沉應じててれらの質的變化及び血小 板數, 網狀赤血球數它測定するととが望ま Uno

第55條 末梢血液障害江次の上万行判定すると とさする。

（1）末枌血液 1 立方 $\mathrm{mm}$. 中の赤血球數が

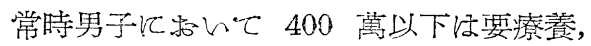

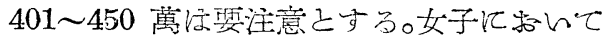

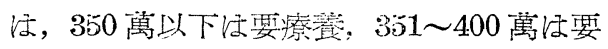
注意とする。

（2）末梢血液 1 立方 $\mathrm{mm}$. 中の白血球數が 4, 000以下注要療養, 4, 100 5, 000 攺要注 意とする。

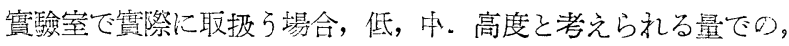

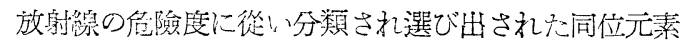

群

放 射能 尺度

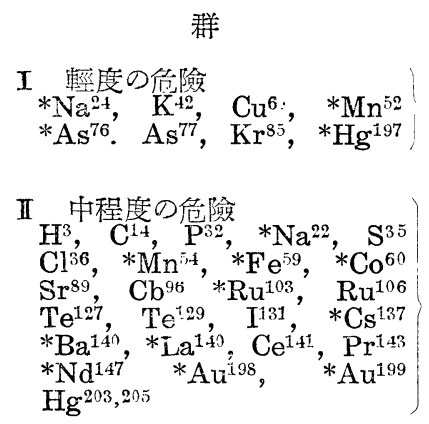

亚 高度の结險

$\mathrm{Ca}^{4+}, \mathrm{Fe}^{i 0}, \mathrm{Fr}^{90}, \mathrm{Y}^{91}, \mathrm{Zr}^{95}$
$\mathrm{Ce}^{14+}, \mathrm{Pm}^{147}, \mathrm{Bi}^{210}$

注 意

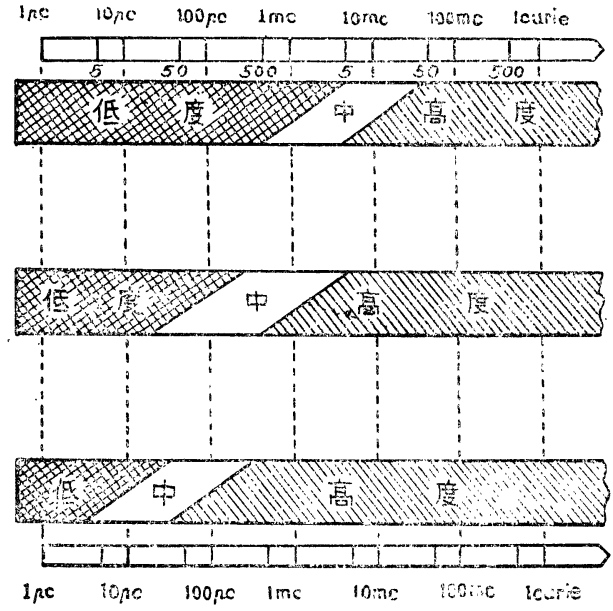

實驗窒に於て坂扱方礼る放射能

○實際の放射繶傷畫は次の曾素を考量して得られる。

本 減 期

放射線の土ネルギー文び性質

體内に於て選燡的に一呞部に留まる程展

排 泄 率

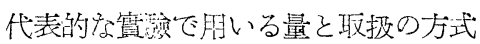

○低, 中, 高度 (Level) の間にある斜の境界線は境界地帶安示し，各 Level そ，そ れに關連しそ防護掕術との間にはっきりした移り變りのないこと定强調している。 ○主な $\gamma$ 線放射物は星印で示されている $\left(\right.$ 例 $\left.* \mathrm{Na}^{2+}\right)$ 上記の伦險度分類方式は外部另 らの照射による伦險には適用されない。 


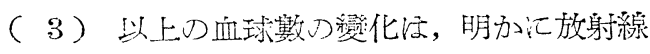

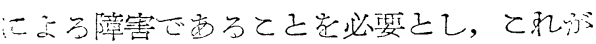
モ的露出放射線量並び沉放射新以外の障害

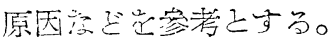

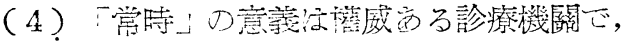

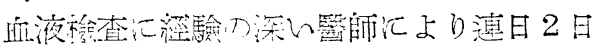

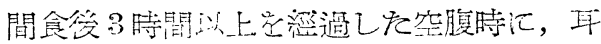

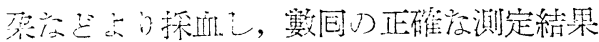

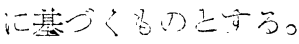

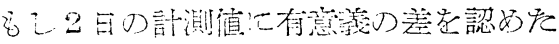

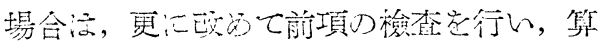

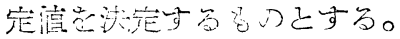

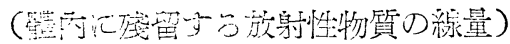

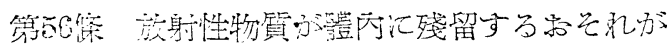

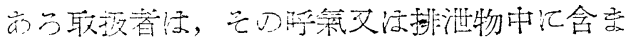

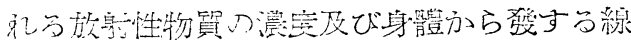

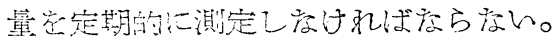

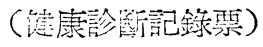

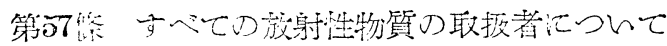

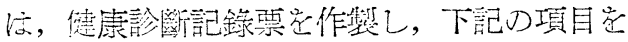
部錄するこ上学要する。

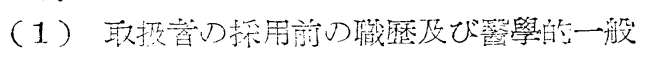
汗照

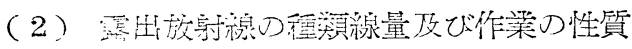

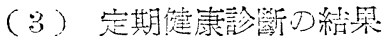

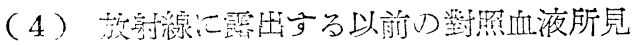

(5) 定期血液䘽查の所見

(6) 气D他必琵度亨垻
第VII章 放射性物質による匴害の

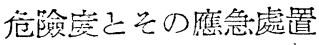

（危險 店）

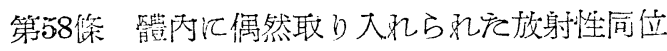
元素汇よって起万障害の程度注，天略前頁の 第 $\mathrm{N}$ 表入通りで亩る。

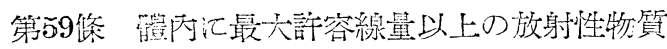
吾を注放射性同位元素が存在するととの認的

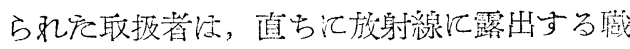

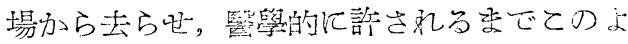

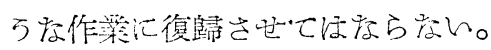

(應急處置)

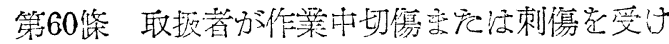

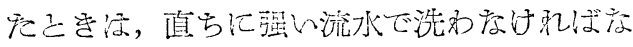
ら想い。

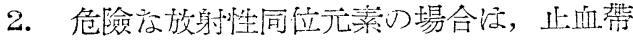

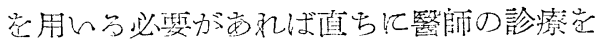
受けらととと与っ。

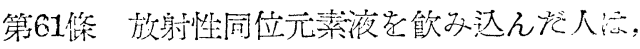

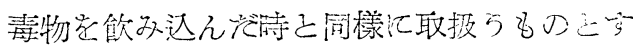
る。

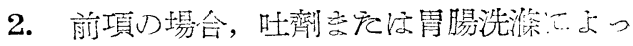

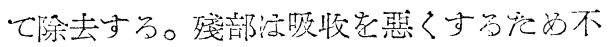
溶性さする。こ㡆らの虎置注必要汇より醫 師の監督の下で行らものとする。

-以 上- 
人工放射性元素の有機化學への雇用

島村修
§1. 有機化學江隹用さ礼る RI
§ 2. RI 立含已有橪化合物门合成
§3. 應 用
§ 4. 同位元素效果
§5. 參考書

\section{§ 1. 有磯化留に應用される RI}

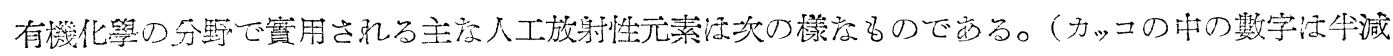

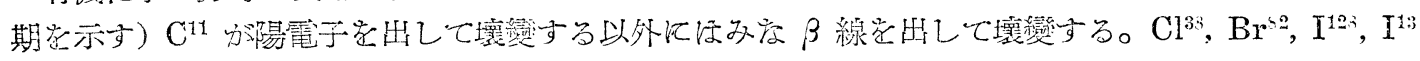
原線学已件万。
$\mathrm{H}^{3}$ (12 年)， $\mathrm{C}^{11}$ (20.35 分), $\mathrm{C}^{1.4}$ (5,370 年), $\mathrm{P}^{32}$ (14.3 日), $\mathrm{S}^{35}$ ( 87.1 日), $\mathrm{Cl}^{36}$ (4.4 $\times 10^{5}$ 年), $\mathrm{Cl}^{39}$ (38.5 分), $\mathrm{Br}^{92}$ (34 時), $\mathrm{I}^{123}$ (25 分), $\mathrm{I}^{131}$ (8.0日)

\section{§ 2. RI を含む有機化合物の合成}

\section{(A) 水素 ( $\mathbf{T})$}

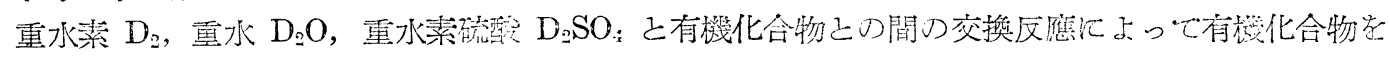

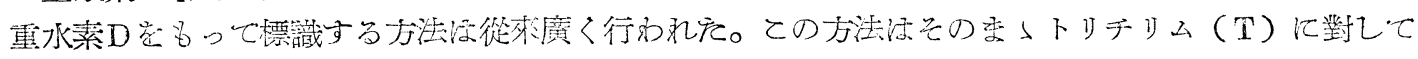

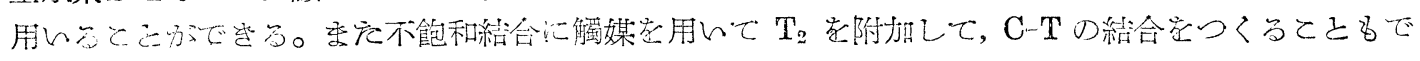
せる。

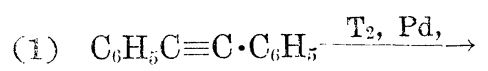<smiles>CCCCCCCCCCCCCCCCCC</smiles><smiles>CCCCCCC</smiles>

I. A. BERNSTEIN 等: Nuc'eonics, 11 (1953), 64.

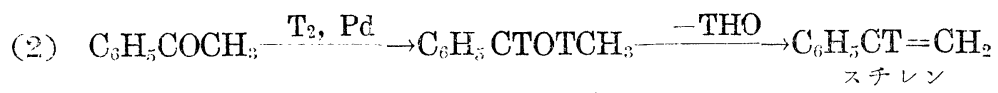

I. A. BeRnStein 等: J. Am. Chem. Soc., 74 (1052), 57 e3.

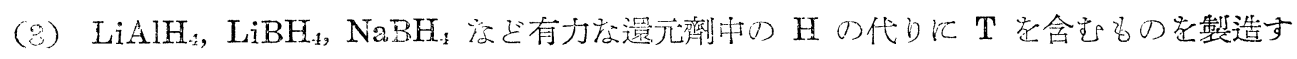

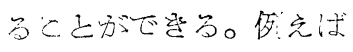

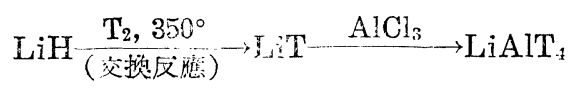

K. E. WilzBAz耳 等: J. Am, Chem. Soe., 72 (1950), 5705, 74 (1552), 1343.

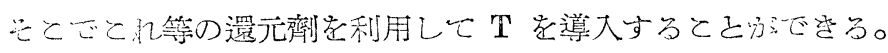

(4) $\mathrm{CH}_{:} \mathrm{COOC}_{2} \mathrm{H}, \stackrel{\mathrm{LiAlT}_{4}}{\longrightarrow} \mathrm{CH}_{3} \mathrm{CHTOH}$ 
(5) $\left(\mathrm{C}_{6} \mathrm{H}_{5}\right)_{3} \mathrm{SiCl}+\mathrm{LiAlT}_{4}-\longrightarrow\left(\mathrm{C}_{6} \mathrm{H}_{5}\right)_{3} \mathrm{SiT}$

(6) J. K. Fukuskima 等：J.Am. Chem. Soc., 74 (1952), 487. は次の樣にしてトリチリ

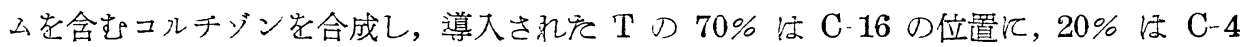
の位置に存在するとと孝示した。

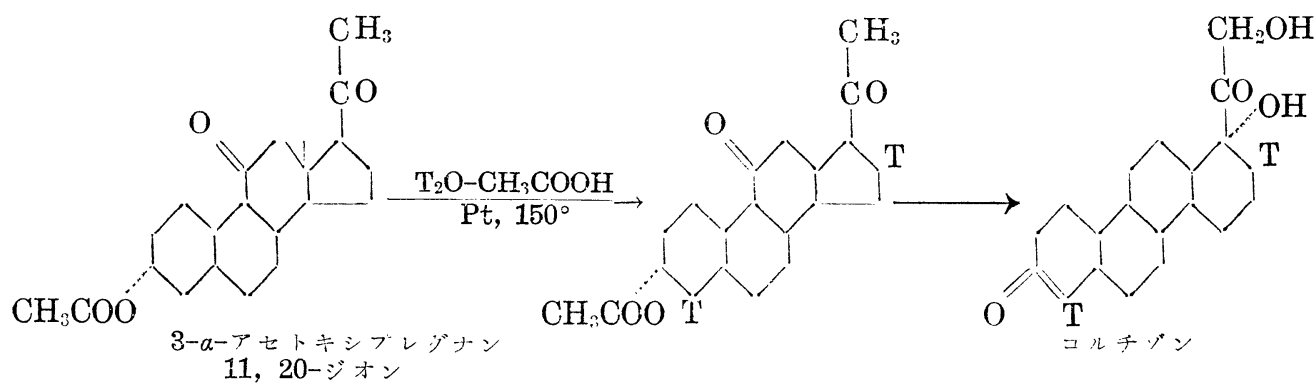

(7) グリニャル反應を使用する例。

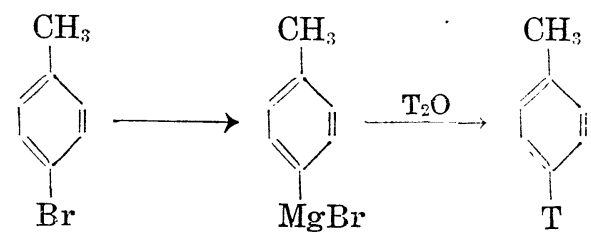

\section{(B) 炭 素 $\left(\mathbf{C}^{11}, \mathbf{C}^{1-1}\right)$}

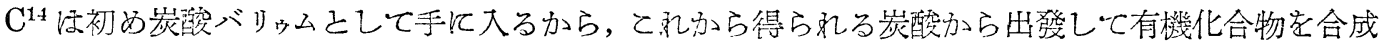
しなけ礼ばなら店い。その第一步の反應は次の樣存もので市る。

(1) $\mathrm{K}_{2} \mathrm{CO}_{3}+\mathrm{Zn}+\mathrm{NH}_{3}-650^{\circ} \rightarrow \mathrm{KCN}$

J. A. Mc CArter: J. Am. Che:n. Soc., 73 (1951), 483.

$\mathrm{BaCO}_{3}+\mathrm{NaN}_{3} \longrightarrow \mathrm{NaCN}$

A. W. Adamson: J. Am. Chem. Soc., 69 (1947); 2564.

(2) $\mathrm{CO}_{2}+\mathrm{LiAlH}_{4} \longrightarrow \mathrm{CH}_{3} \mathrm{OH} \stackrel{\mathrm{HI}}{\rightarrow} \mathrm{CH}_{3} \mathrm{I}$

J. D. Cวx等: J. Chem. Soc., 1950, 3,167.

(3) $\mathrm{CO}_{2}+\mathrm{NH}_{3} \longrightarrow \mathrm{H}_{2} \mathrm{NCOONH}_{2} \stackrel{135^{\circ}}{\longrightarrow} \mathrm{H}_{2} \mathrm{NCONH}_{2}$

A. L. Myerson: J. Am. Chem. Soc., 74 (II52), 2437.

(4) $\mathrm{CO}_{2}+\mathrm{Zn} \stackrel{400^{\circ}}{\rightarrow} \mathrm{CO}+\mathrm{ZnO}$

R. B. BernsteIn: Science, 106 (1947), 498.

$\mathrm{CaCO}_{3}+\mathrm{Zn} \stackrel{750^{\circ}}{\rightarrow} \mathrm{CO}+\mathrm{C2} \mathrm{O}+\mathrm{ZnO}$

S. Weinhouse: J. Am. Chem. Soc., 70 (1948), 442.

(5) $\mathrm{CO}_{2}+\mathrm{LiBH}_{4} \longrightarrow \mathrm{HCOOH}$

J. G. Burr 等: J. Am. Chem. Soc., 72 (1950), 2560.

(6) $\mathrm{BaCO}_{3}+\mathrm{NH}_{3}+\mathrm{NaN}_{3} \longrightarrow \mathrm{H}_{2} \mathrm{NCN}$

S. Schuching 等: J. Am. Chem. Soc., 72 (1950), 3717.

(7) $\mathrm{CH}_{3} \mathrm{OH} \quad \mathrm{Mo}$ と $\mathrm{Fe}$ との酸化物, $\mathrm{O}_{2} \rightarrow \mathrm{CH}_{2} \mathrm{O}$ 
A. Murray 等：J. Am. Chem. Soc., 74 (1952), 2405.

(8) $\mathrm{CH}_{3} \mathrm{COCl}+\mathrm{C}^{*} \mathrm{H}_{3} \mathrm{OH} \longrightarrow \mathrm{CH}_{3} \mathrm{COOC}^{*} \mathrm{H}_{3}$

$\mathrm{CH}_{3} \mathrm{COOC}^{*} \mathrm{H}_{3}+\mathrm{Cl}_{2} \longrightarrow \mathrm{CH}_{3} \mathrm{COOC}^{*} \mathrm{H}_{2} \mathrm{Cl}+\mathrm{HCl}$

$\mathrm{CH}_{3} \mathrm{COOC}^{*} \mathrm{H}_{2} \mathrm{Cl}+\mathrm{H}_{2} \mathrm{O} \longrightarrow \mathrm{CH}_{2} \mathrm{COOH}+\mathrm{C}^{*} \mathrm{H}_{2} \mathrm{O}+\mathrm{HCl}$

A. R. Jones 等: J. Am. Chem. Soc., 74 (1952), 2437.

(9) $\mathrm{BaCO}_{3}+2 \mathrm{Mg} \longrightarrow \mathrm{BaC}_{2}+\mathrm{BaO}$

又住 $2 \mathrm{CO}_{2}+5 \mathrm{Ba} \longrightarrow \mathrm{BaC}_{2}+4 \mathrm{BaO}$

$\mathrm{BaC}_{2}+2 \mathrm{H}_{2} \mathrm{O} \longrightarrow \mathrm{CH} \equiv \mathrm{CH}+\mathrm{Ba}(\mathrm{OH})_{2}$

R. D. CRAMER 等：J. Bio'. Chem., 137 (1941), 54\%.

W. J. ARROL 等: Nature, 159 (1947), 810.

（10）グリニヤル或注類似反應によるカルボン酸の合成

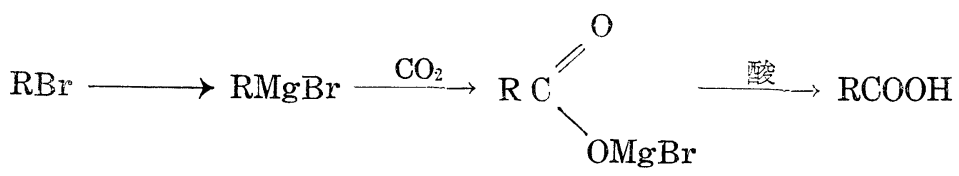

$\mathrm{O}$

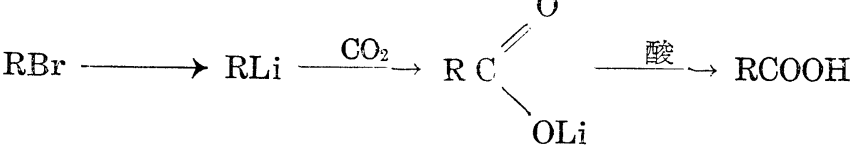

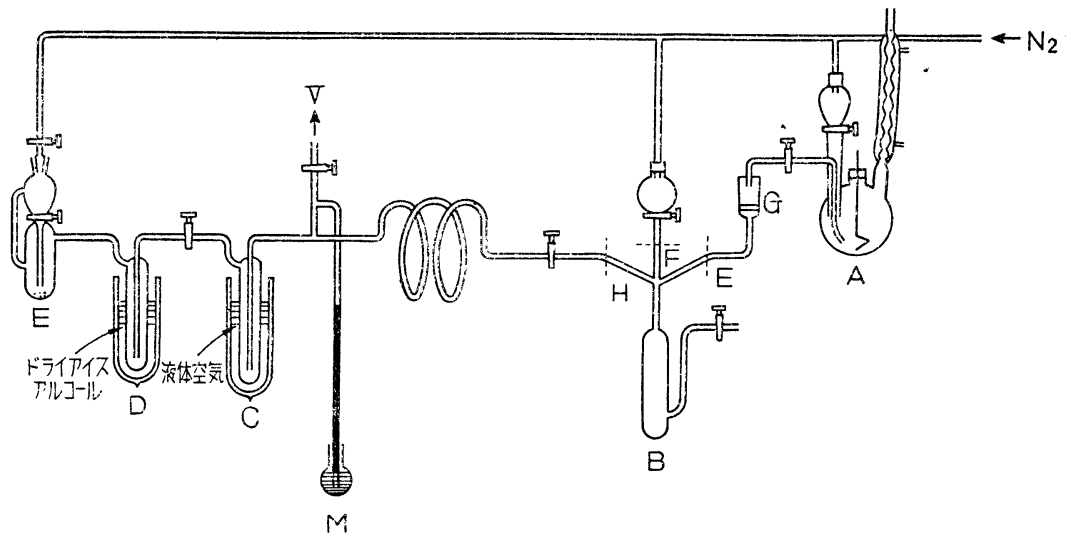

以上の樣にして得られた化合物を原料として更に襀雜存るのを合成するてとができる。

合成 例 1. $\mathrm{P}$ ーアミノ安息香酸一(カルボキシー $\left.\mathrm{C}^{14}\right)$

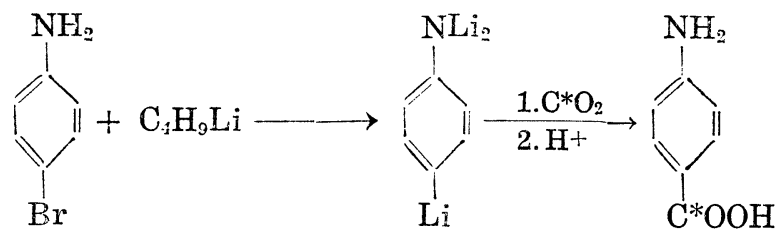

合成 例 2. ベンゼンー $\mathrm{C}^{14}$ 
<smiles>CCCCCCCCCCCC(=O)C1CCC(C(=O)O)CC1</smiles><smiles>C=C(CCCCCCCCCCC)CCCC[N+](=O)[O-]</smiles>

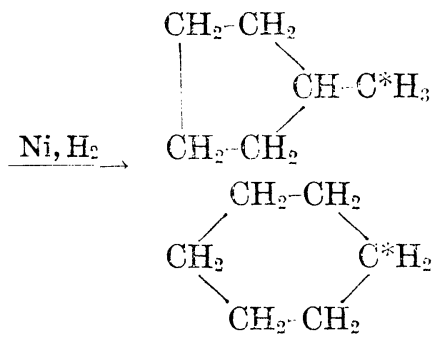<smiles>CCCC1CCCCC1</smiles>

H. S. TURNER: Nature, 168 (1951), 73.

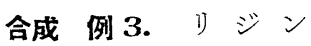

$$
\begin{aligned}
& \mathrm{KC}^{*} \mathrm{~N}+\mathrm{Br}\left(\mathrm{CH}_{2}\right)_{3} \mathrm{Cl} \longrightarrow \mathrm{NC} *\left(\mathrm{CH}_{2}\right)_{2} \mathrm{Cl} \underset{\mathrm{T}_{2} \mathrm{CO}_{2} \mathrm{H}_{5}}{\stackrel{\mathrm{CH}_{5}}{\mathrm{COOC}_{2} \mathrm{H}_{2}} \rightarrow} \rightarrow \\
& \mathrm{NC}^{*}\left(\mathrm{CH}_{2}\right)_{;} \mathrm{CH}\left(\mathrm{COOC}_{2} \mathrm{H}_{i}\right)_{2} \frac{\mathrm{C}_{2} \mathrm{H}_{3} \mathrm{ONO}}{\mathrm{N}_{2} \mathrm{OC}_{2} \mathrm{H}_{5}} \rightarrow \mathrm{NC} *\left(\mathrm{CH}_{2}\right)_{3}-\underset{\mathrm{NOH}}{\mathrm{C}-\mathrm{COOC}_{2} \mathrm{E}_{-5}} \\
& \begin{array}{l}
\text { 1. } \mathrm{H}_{2}, \mathrm{Pt} \\
\text { 2. } \mathrm{HCl}
\end{array} \\
& \mathrm{DL} ー \text { リジンー } \mathrm{NH}_{2}-\mathrm{C}^{\mathrm{i}-\mathrm{i}}
\end{aligned}
$$
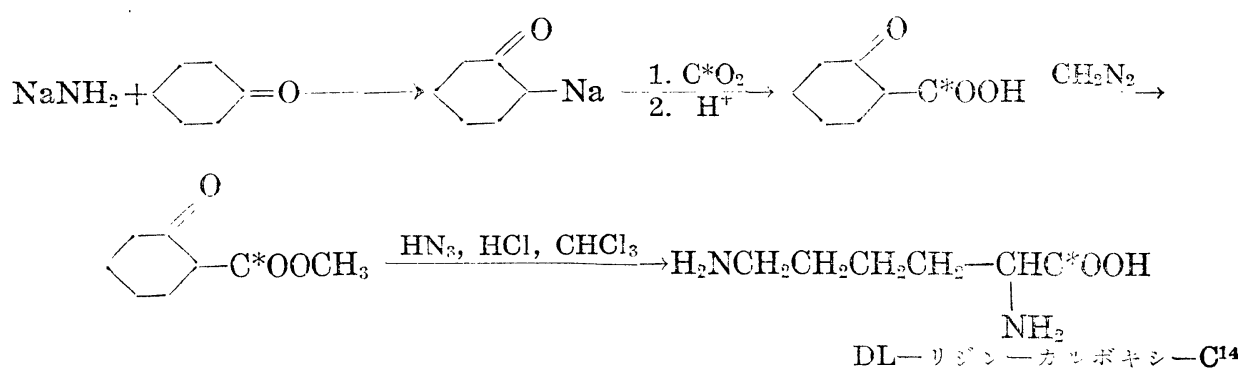

H. R. V. ARnsteIn 等： J. Chem. So:., 1952, 1329.

(C) 硫 黄 ( $\mathbf{S}^{35}$ )

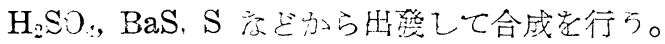


例 1. $\mathrm{C}_{6} \mathrm{H}_{3} \mathrm{NH}_{2} \cdot \mathrm{H}_{2} \mathrm{~S} * \mathrm{O}: \longrightarrow \mathrm{P}-\mathrm{H}_{2} \mathrm{~N} \longrightarrow-\mathrm{S}^{*} \mathrm{O}$

スルフンル酸

J. S. Ingraham: J. Am. Chem. Sos., 74 (1952), 2433.

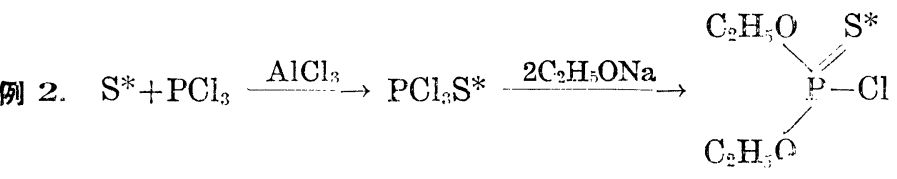

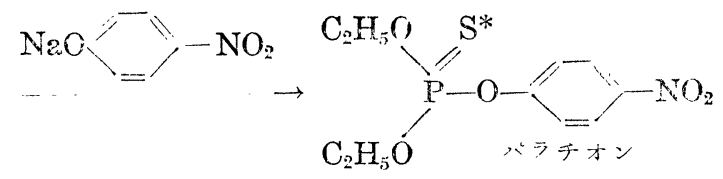

J. A. Jensen 等: J. Am. Chem. Soc.. 74 (1952), 3184.

例 3. $\mathrm{BaS}^{*} \longrightarrow \mathrm{CaS}^{*} \stackrel{\mathrm{HPO}_{3}}{\rightarrow} \mathrm{H}_{2} \mathrm{~S}^{*} \stackrel{\mathrm{H}_{2} \mathrm{NCN}}{\longrightarrow} \underset{\text { 千尿素 }}{\left(\mathrm{H}_{2} \mathrm{~N}\right)_{2} \mathrm{CS}^{*}}$

C. W. Bills 等: J. Am. Chem. Soc., 72 (1050), 5510.

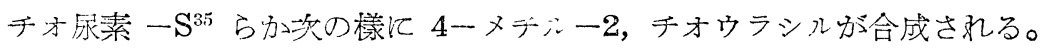<smiles></smiles>

M. J. E. ERnsting 等: Chem. Abst., 44 (i950), 3444.

(D) $\mathbf{P}$ 燐 $\left(\mathbf{P}^{32}\right)$

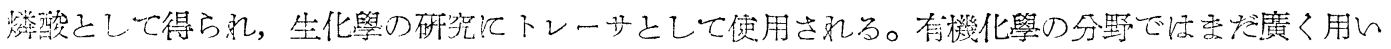
方就て教。

\section{(E) ハロ ゙ン}

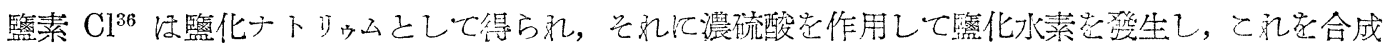

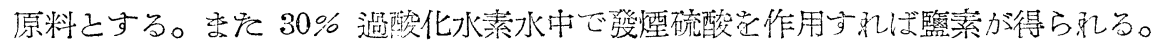

反應例 (1) $\mathrm{CHCl}=\mathrm{CH}-\mathrm{CH}_{2} \mathrm{OH} \stackrel{\mathrm{HCl} *}{\rightarrow} \mathrm{CHCl}=\mathrm{CH}-\mathrm{CH}_{2} \mathrm{Cl}^{*}$

L. F. HATCH 等：J. Am. Chem. Soe., 74 (152), 1826.

(2) $\mathrm{CH}_{3} \mathrm{CONH}_{=}+\mathrm{Cl}_{2}^{*}-\longrightarrow \mathrm{CH}_{3} \mathrm{CONH} \longrightarrow \mathrm{Cl}^{*} \stackrel{\mathrm{COCl}_{2}}{\rightarrow} \rightarrow \mathrm{OCN}^{-}-\mathrm{Cl}^{*}$

H. H. Wceber: J. Am. Chem, Sor., $7+$ (1952), 1354.

(3) $\left.\mathrm{C}_{6} \mathrm{H}_{5}+\mathrm{N} \equiv \mathrm{N}\right\} \mathrm{Cl}^{-}+\mathrm{NaI}^{*} \longrightarrow \mathrm{C}_{6} \mathrm{H}_{5} \mathrm{I}^{*}+\mathrm{NaI}$

(4) $2 \mathrm{C}_{6} \mathrm{H}_{5} \mathrm{I}^{*}+\mathrm{CCl}_{3} \mathrm{CHO} \longrightarrow\left(\mathrm{I}^{*}-(-)_{2} \mathrm{CHCl}_{3}\right.$

J. A. Jensen 等: J. Am. Chem. Soc., 74 (1952), 2430.

\section{§3. RI を含む化合物の應用}

\section{1. 稀釋分析法}

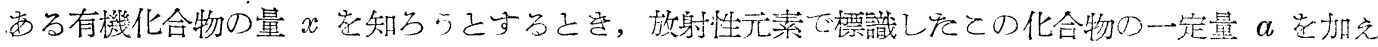




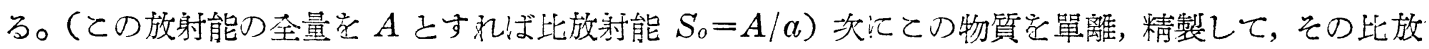
射能 $S$ 在測定する。容易汇わかる樣汇 $S=A /(\alpha+x)$ であるから $x=\alpha\left[\left(S_{o} / S\right)-1\right]_{0}$ 比放射能 ( $\left.S_{0}\right)$ 既

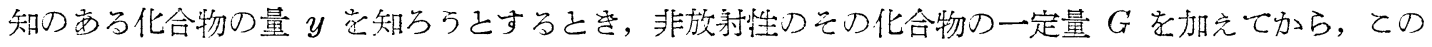
化合物老單離し，精製後比放射能 $(S)$ 党測定す机壮，

$$
y=G S /\left(S_{o}-S\right)
$$

この方法法 Carrier 涯加法で西る。

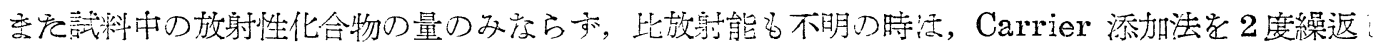
て應用す礼ば，兩方を泳めるてこができる。(二重稀釋法の例；R. H. MAYOR 等：J.Am.Chem. Soc., 73 (1951), 471.)

例 1. A. S. KeSTON 等：J.Am. Chem. Soc., 72 (1950), 748 庄蛋白質 (0.2 1mg.) の加水分 解物に $\mathrm{p}-\mathrm{I}^{151} \mathrm{C}_{6} \mathrm{H}_{i} \mathrm{SO}_{2} \mathrm{Cl}$ 老作用して，アミノ酸を $\mathrm{p}$ ーヨードフニニルスルホニル化合物としててれを 滤緍クロマトグラフ法で分别, 定量す当ととができた。その際收率を知るために, 問題つアミノ酸の $\mathrm{p}$ ーヨードフ:ニルスルホニル $\left(\mathrm{S}^{35}\right)$ 化合物老添加した。

例 2. Nーニトソロアセトアニリドをベンゼン中心゙分解すると，次の樣汇遊離基つ關與する反應が 忑こって主としてビフニニルを生䄈が，

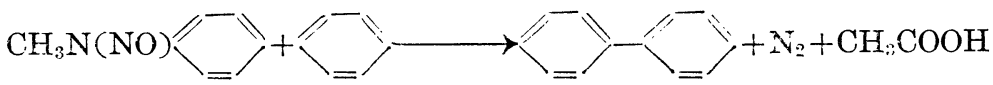

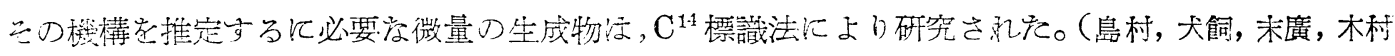
日本化學會第六年會, (1853).)

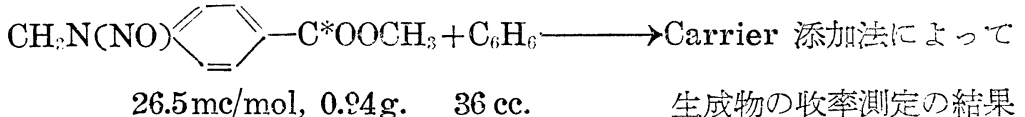

$26.5 \mathrm{mc} / \mathrm{mol}, 0.84 \mathrm{~g} .36 \mathrm{cc}$. 生成物の收率測定つ結果
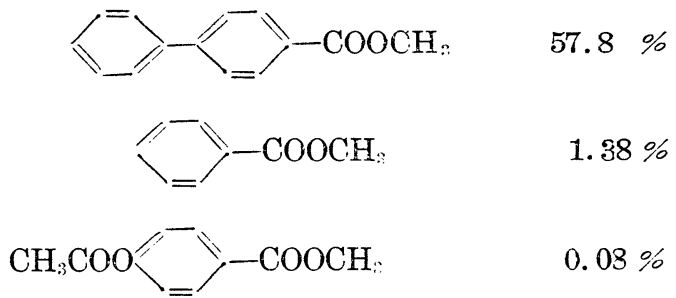

例 3.
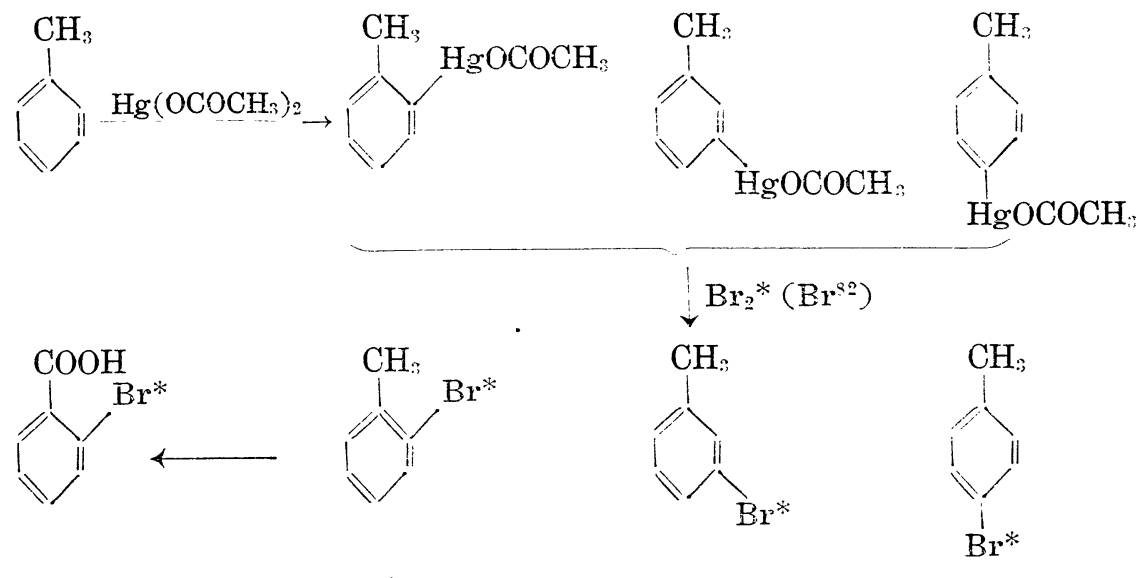
ブロムトルェン混合物を三分してそれらに，o，m 或住 $p$-ブロムトルェンをそれぞれ Carrier 上 して加え, 酸化してブロム安息香酸の三異性體を單離, 精製して, Br*の放射能を測って異性體比を 求めた。 (KLAPPROTH 等: J. Am. Chem. Soc., 72 (1950), 4461.)

結 果 $\quad o: m: p=41: 21: 37$

\section{2. 標 識 法}

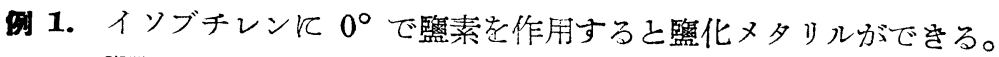<smiles>CC(C)=CCCl</smiles>

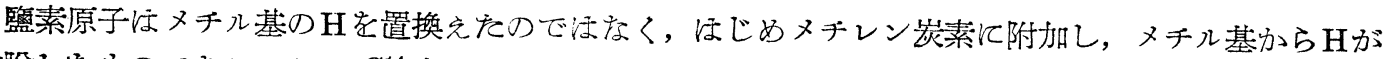
離脫したるのであるてこが $\mathrm{C}^{1.4}$ 標識法で明か沉なった。（W. REEVE 等：J.Am. Chem. Soc., 74 (1952), 5369.)

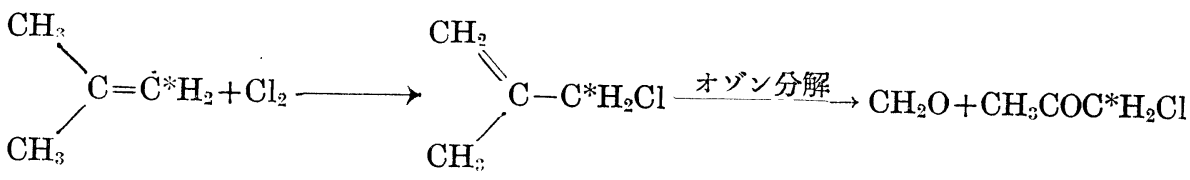

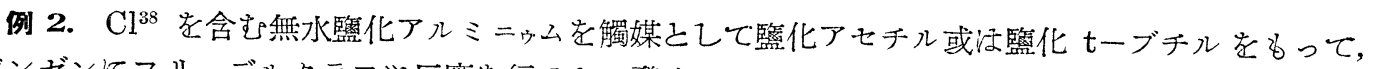
ベンゼンにフリーデルクラフツ区應を行らと, 發生してくる鹽化水素中の $\mathrm{Cl}^{38}$ の濃度とフラスコ中に 殘っている監索中の $\mathrm{Cl}^{38}$ の濃度とが等しいとこがわかった。（FA1RBROTHER：J. Chem. Soc., 1937 503.)

反應飞 $\mathrm{CH}_{3} \mathrm{C}^{+} \mathrm{O}\left(\mathrm{AlCl}_{4}\right)^{-}$或住 $\left(\mathrm{CH}_{3}\right)_{3} \mathrm{C}^{+}\left(\mathrm{AlCl}_{4}\right)^{-}$型の錯化合物が關與する證掉である。

例 3. 光學活性沃化オクチルがアセトン中沃化ナトリッムの存在でラセミ化する速度こ，沃化オク チルが $\mathrm{NaI}^{*}\left(\mathrm{I}^{125}\right)$ と作用して沃素を交換する速度住一致した。（E. D. HugHES 等：J. Chem. Soc., 1935, 1525)<smiles>CCCCC(C)[AlH]C</smiles><smiles>CCCCC(C)[In]C(C)[In]</smiles>

二分子的求核置換反應 $\left(\mathrm{SN}_{2}\right)$ がワルデン轉位を伴らことの證掽である。

\section{$\S 4$. 同位元素效果}

同位元素標識法を應用するとあたって，根本的の假定ほ同位元素異性體 (Isotopic Isomer) ほ化學

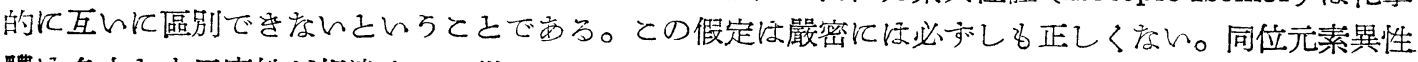
體主少とる反應性が相違する。從って，例えば常水から重水素を分離することがでをるのである。

例 1. $\left(\mathrm{C}_{6} \mathrm{H}_{5}\right)_{3} \mathrm{SiH}+\mathrm{H}_{2} \mathrm{O} \stackrel{\mathrm{C}_{5} \mathrm{H}_{11} \mathrm{~N}}{\rightarrow}\left(\mathrm{C}_{6} \mathrm{H}_{5}\right)_{3} \mathrm{SiOH}+\mathrm{H}_{2}$

トリフェニルシランーt とつんて筫驗すると反應の後期に發生する水素程トリチッム岁多く含む。そ 
の濃度から上記の反應の速度恒數の比注 $k_{T} / k_{H}=0.796$

(L. KAPLAN 等: J. Am. Chem. Sos,, 74 (1952), 6,152.)

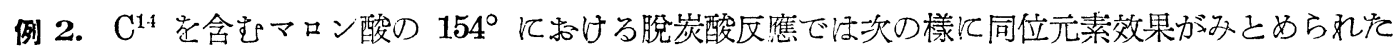
(G. A. Ropp 等: J. Am. Chem. Sos., 74 (1952), 4,992.

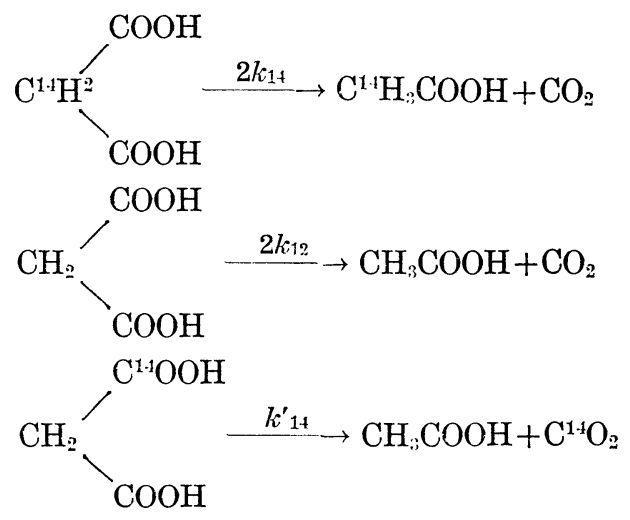

$k_{1:}$ 等注反應速度恒數であって

$$
k_{14} / k_{12}=0.929 ; \quad k_{1:}^{\prime} / k_{12}=0.939
$$

で㐫った。

例 3. カルボニル基の一方に $\mathrm{C}^{14}$ をるつベンジルのベンジル酸轉位は同位元素效果を示す。

(W. H. Stevens 等: J. Chem. Phys., 18 (1950), 574.)

$$
\mathrm{C}_{6} \mathrm{H}_{5} \mathrm{C}^{*} \mathrm{OCOC}_{6} \mathrm{H}_{5} \stackrel{\text { アルカンリ }}{\longrightarrow}\left\{\begin{array} { l } 
{ ( \mathrm { C } _ { 6 } \mathrm { H } _ { 5 } ) _ { 2 } \mathrm { COH } \cdot \mathrm { C } ^ { * } \mathrm { OOH } } \\
{ ( \mathrm { C } _ { 6 } \mathrm { H } _ { 5 } ) _ { 2 } \mathrm { COH } \cdot \mathrm { C } ^ { * } \mathrm { OOH } }
\end{array} \stackrel { \mathrm { Pp } ( \mathrm { OCOCH } _ { 3 } ) _ { 4 } } { \longrightarrow } \rightarrow \left\{\begin{array}{l}
\left(\mathrm{C}_{6} \mathrm{H}_{5}\right)_{2} \mathrm{CO}+\mathrm{C}^{*} \mathrm{O}_{2} \\
\left(\mathrm{C}_{6} \mathrm{H}_{5}\right)_{2} \mathrm{C}^{*} \mathrm{O}+\mathrm{CO}_{2}
\end{array}\right.\right.
$$

ベンジフェノンの比放射能から $\mathrm{C} *$ の位置の違らベンジル酸の量比が知れる。

$$
\frac{\left(\mathrm{C}_{6} \mathrm{H}_{5}\right)_{2} \mathrm{C} * \mathrm{OHCOOH}}{\left(\mathrm{C}_{\hat{0}} \mathrm{H}_{5}\right)_{2} \mathrm{COHC} * \mathrm{OOH}}=1,11 \pm 0.01
$$

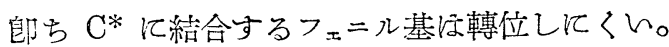

同位元素效果注簡單にんらと, 同位元素のために, 化合物つ始原系之遷移狀態の振動の零點エネル ギー方變化するととによると考えられる。

(J. Biegeleisen：J. Chem. Phys., 17 (1949), 425; H. Egring 等：J. PhysChem., 56 (1952), 889.) 反應の律速段階が同位元素の原子のつくる結合の變化を含む場合は, 著しく同位元素效果注現わ机る。 故にこの效果の存否ほ反應機構の研"宛に利用できる。

同位元素效果の認られぬ例：

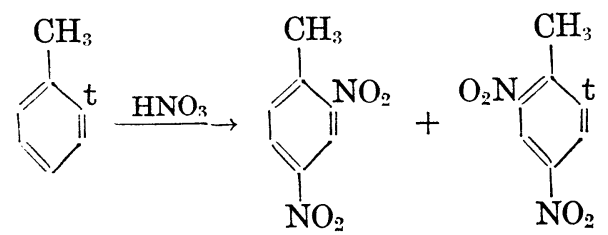

生成物中のトリチゥムの量ほ原料中の量の $50 \%$ であった。

(L. Melander: Arliv. Kemi., 2 (1950), 211.

酶酸リチゥムを $430^{\circ}$ 飞熟すると收率よくアセトンを生和るが，

$2 \mathrm{CH}_{3} \mathrm{COOLi} \longrightarrow \mathrm{CH}_{3} \mathrm{COCH}_{3}+\mathrm{Li}_{2} \mathrm{CO}_{3}$ 
$\mathrm{CH}_{3} \mathrm{C}^{*} \mathrm{OOLi}$ 孝用いて，同位元素效果活見出されなかった。

(A. Rose 等: J. Am. Chem. Soc., 74 (1952), 2442)

\section{$\S$ 參考書}

實驗法につんてては,

M. CALvin 等: Isotopic Carbon, John Wiley, (1949).

M. D. KAMEN: Radioactive Tracers in Biology, Academic Press, (1951).

$\mathrm{RI}$ 崖含む有㙨化合物のリストとその簡單な說明についてね，

C. E. CRompton 等: Nuc'eonics, 7 (1950), No. 3, 49; No. 4, 44.

身村等：有機合成化學最近の進步，應用糄，(1953)，404.

$\mathrm{C}^{1 \cdot 4}$ の應用的つんては，

G. A. ROPP 等: Nucleonics, 9 (1951), No. 2, 22.

同位元素效果炕つんては,

G. A. Ropp: Nucleonics, 10 (1952), No. 10, 22. 


\section{第二日. $(8$ 月 25 日) 午後 \\ 放射性同位元素の生化學への哕用}

放射性同位元素索生物の物質代謝の研究に應 用した先媐者注 Hevesyであった (1)。彼が最初 利用したの注 $\mathrm{RaD}$ で西ったが，てのものは Ra の逐次崩壞飞よって生亦る鉛の同位元素であ るが，RaD 鉛から分離するとこが不可能な 事實から，之利用して RaD 考含む鉛の放射 能ををよりに硫化鉛，クローム酸鉛の溶解度を 測定した。その後 1923 年にこのとと老禃物に 擴張し, 鉛の稙物に心ける吸收, 移動の研究を 行い(2),ついだ RaD 及び蒼鉛の同位體なる $\mathrm{Ra}$ $\mathrm{E}$ を用的て鉛及び蒼鉛つ動物體における吸收及 び排泄の研究をした(3)。虽時任天然の放射性元 素か唯一の材料で西ったので應用の範圍沅せま かったが, 1934 年 Curie 及び Joliot り人工放 射性同位元素の發見活しの極限された應用範圍 を著しくひろげる動機さなった。1935 年 Chiewitz 及び Hevesy ${ }^{(1)}$ 注人工放射性燐 $\mathbf{P}^{32}$ 孝初 めて動物の代謝研究に應用した。

人工放射性元素の發見の少乙前儿重水素Dが 發見され，Hevesy 改び Hofer ${ }^{(5)}$ 任之岂む 水它以て金魚の水代謝つ研究索行ったのが 1934 年で, 後に Schoenheimer一派が脂酸及びアミ つ酸の代謝古この重水素及び重窒素 $\mathrm{N}^{15}$ を用い て研究しを(6)。

第二次大戰の注じまるまで,主として米國で,
東大醫學部 吉 川 春 壽

サイクロトロンから生產される放射性同位元 素, 及び天然江存する非放射性同位元素を分離 乃至濃縮したもので廣範圍にわたる生理化學的 研究が開始され，日本でも故仁科博士の下に森: 博士等が放射性同位元素を用いて研究湆手手し そので西った(゙)。戰前迄の放射性同位元素を生 物學に利用した硹究については私のまとめを綜 說が西るからそれを參照せられたい(8)。不幸沉 して大戰のため, わが國の同位元素利用の研究 任困難となり，来國においてすら戰争目的のた めにこの方面の發展怔停頓していた。しかし一 方で戰争逐行の目的で米國において企畫され

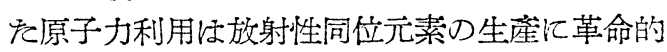
な進步をあたえた。郎ちプルトニッム $\mathrm{Pu}$ 生愿 の爲につくられた所謂ウラニッムパイルー現在

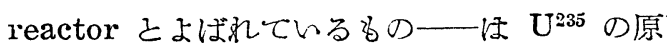
子核分裂に上って豐富な中性子雲を發生するの で，之を種及の元素に市て，放射性同位元素它 之までになく大量に生產し得るようになった。 現在 Oak Ridge 江西る reactor から米國國 內のみ方市外國にまで之が有料配布されて居

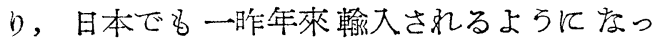
$k^{(3)}$ 。

1948年迄の同位元素の生物學への應用に關す 万硎究の題目己掍載誌名浪の Siri の著書にの

(1) G. HEVESY: Radioactive Indicators, (1948).

(2) G. Hevesy: Biochem. J., 17 (1923), 439.

(3) J. A. Ceiristiansen, G. Hevesy and S. Lomholt: C. r., 178 (1924), 1324; 179 (1924), 291.

(4) O. Chiewitz and G. Hevesy: Nature, 136 (1935), 754.

(5) G. Hevesy and E. Hofer: Z. Physiol. Chem., 225 (1934), 28.

(6) R. Schoenheimer and D. Rittenberg: Physio'. Rev., 20 (1940), 218.

(7) 森: 日本生理學骅論, 1 (1941), 100.

(8) 吉川：日新醫學，32 (1942), 13, 191，488，579.

(9) P. C. Aebersold: Chem. \& Eng. New, 27 (1949), 1430.

吉川譯：化學の領域, 5 (1951), 615 .

(9a) Siri. 
っている(9a)。

Oak Ridge から供給されるものほ U235 の原 子核分裂で生なる fission product 上, 先江の

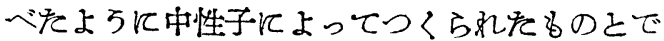
西るが， I $I^{131}$ を除いてはすへて後者の反應によ って生举されている。後者活更に

(1) 中性子吸收 $(n, \gamma)$

(2) 變換 $(n, p)$ 又注 $(n, \alpha)$

(3) $(n, \gamma)$ 区應炕つずく崩境

によって生ずる三つの樣式がある。(1) ほ的と 䄈った元素と同じ同位元素を生ずるので, 不活 性の原子の中の少數のみが放放射能をるつに 過ざな。換言す礼ば比放射能 (specific activity一一單位質量あたりの放射能）が小さ
レ。之に反して（2）及び（3）の反應によれ ば親元素己は別の元素が新しく出來るのである から, そてに不純物として存在していた當の安 定元素汃をい限り不活性原子を全く含まない carrier-free の材料が得られるわけで，比放 射能は極めて大である。比放射能柱實驗目的に よって適當得ぶべきで亦る。

第 I 表に注現在輸大可能の同位元素で生物學

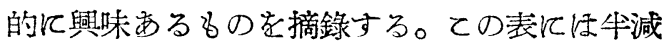
期が 8 日未滿のるのは我國では利用困醮なので 除いて亩る。

半減期の短か人同位元素致今のとてろ日本で は利用し得ないが, 東京の科研及び京大にサイ クロトロンを建造するととになった故，るし之

第I 表 生化學に應用される放射性同位元素

\begin{tabular}{|c|c|c|c|c|c|c|c|}
\hline 元 素 & 形 & 放 射 線 & 牛 減 期 & $\beta \quad(\mathrm{Mev})$ & $\gamma \quad(\mathrm{Mev})$ & 比放射能 & AEC No.* \\
\hline $\mathrm{C}^{14}$ & $\mathrm{BaCO}_{3}$ & $\beta^{-}$ & 5,100 年 & 0.156 & & $\mathrm{C}^{1+} / \mathrm{C}:<12 \%$ & $6 \mathrm{~A}-\mathrm{P}$ \\
\hline $\mathrm{C}^{14}$ & " & , & $"$ & , & & $\mathrm{C}^{1} \cdot / \mathrm{C}:>12 \%$ & $6 \mathrm{~B}-\mathrm{P}$ \\
\hline $\mathrm{P}^{32}$ & $\mathrm{H}_{3} \mathrm{PO}_{4}$ & $\beta-$ & 14.3 日 & 1.71 & & $0.025 \mathrm{mg} / \mathrm{mc}$ & $15 \mathrm{~A}-\mathrm{P}$ \\
\hline$S^{35}$ & $\mathrm{H}_{2} \mathrm{SO}_{4}$ & $\beta-$ & 87.1 日 & 0.12 & & C.F.* & $16-\mathrm{PA}$ \\
\hline$S^{35}$ & $\mathrm{BaS}$ & $"$ & $"$ & " & & $>10 \mathrm{mc} / \mathrm{mg} \mathrm{s}$ & $16-\mathrm{PB}$ \\
\hline $\mathbf{S}^{35}$ & $\mathrm{~S}$ & , & $"$ & " & & $>1 \mathrm{mc} / \mathrm{mg}$ & $16-\mathrm{PC}$ \\
\hline $\mathrm{Cl}^{36}$ & $\mathrm{HCl}$ & $\beta-$ & $10^{6}$ 年 & 0.64 & & $0.01-0.2 \mathrm{mc} / \mathrm{g}$ & $17-\mathrm{P}$ \\
\hline $\mathrm{Ca}^{45}$ & $\mathrm{CaCl}_{2}$ & $\beta-$ & 180 日 & 0.25 & & C.F. & 20-PA \\
\hline $\mathrm{Ca}^{45}$ & " & " & ", & " & & $0.2-0.4 \mathrm{mc} / \mathrm{g}$ & $20-\mathrm{PB}$ \\
\hline $\mathrm{Ca}^{45}$ & $"$ & " & $"$ & " & & $5-20 \mathrm{mc} / \mathrm{mg}$ & $20-\mathrm{PC}$ \\
\hline $\mathrm{Ca}^{45}$ & $"$ & " & $"$ & " & & $1,000 \mathrm{mc} / \mathrm{mg}$ & $20-\mathrm{PX}$ \\
\hline $\mathrm{Fe}^{55}$ & $\mathrm{FeCl}_{2}$ & $\mathrm{~K}, \mathrm{X}$ & 4 年 & & 0.0075 & $300 \mathrm{mc} / \mathrm{g}$ & $26-\mathrm{PA}$ \\
\hline $\mathrm{Fe}^{59}$ & $"$ & $\beta^{-}, \gamma$ & 47 日 & $0.26 \cdot 0.46$ & $1.10 ; 1.30$ & $>1 \mathrm{mc} / \mathrm{g}$ & $26-\mathrm{PB}^{* * * 1}$ \\
\hline $\mathrm{Fe}^{59}$ & $"$ & " & " & , & , & $>500 \mathrm{mc} / \mathrm{g}$ & $26-\mathrm{PX}^{* * *}$ \\
\hline $\mathrm{Co}^{69}$ & $\mathrm{CoCl}_{3}$ & $\beta^{-}, \gamma$ & 5.3 年 & 0.31 & $1.10 \cdot 1.30$ & $>100 \mathrm{mc} / \mathrm{g}$ & $27-\mathrm{P}$ \\
\hline $\mathrm{Zn}^{65}$ & $\mathrm{ZnCl}_{2}$ & $\beta^{-}, \mathrm{K}, \gamma, e$, & 250 日 & 0.32 & 1.14 & $75-300 \mathrm{mc} / \mathrm{g}$ & $30-P$ \\
\hline $\mathrm{I}^{131}$ & $\mathrm{I}^{-}$ & & 8.0 日 & 0.6 & $0.367 ; 0.283$ & C.F. & $53-F$ \\
\hline
\end{tabular}

* AEC 同位元素カタログの番號

** Carrier free

*** $\mathrm{Fe}^{55}$ を混ずる

が完成すれば $\mathrm{Na}^{24}$ のような短命のものも利用

乙得られるるの之期待される。

生化學的研究にとの放射性同位元素索利用す る道に二つる。その第一は Hevesy とよっ て開始されたように，物質の生物體內における
變化行方を追究するため物質の目印として 利用される場合で, いわゆる tracer として利 用する力法で西る。第二住 Radium と同樣に 放射線源乞して，その放射線の生理作用を調 べるこか, あるい柱組織汇よる放射線吸收度を 
利用する種々の測定つ場合で, 治療目的で外部

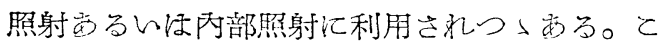

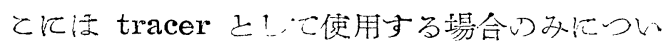
て述的总汇与。

放射性同位元素老 tracer 上して使用乙得万 乞いらとさ汪，之の原子小筫量，放射線の特性 が，三つ元系の化合樣式，存在場所汇よっで全 く影響されずぼしまでるての特性志目印とし

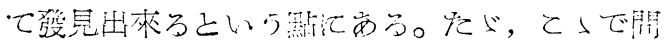
題江宗々心汪,

（1）覧量の相淮が化學反應汇影響を與える 乙上（同位元素效果 isotopic effect)

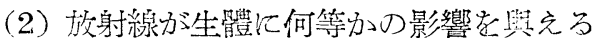
乙上（放射線效果 radiation effect) の二この效果つ壳めに，同位元素孛用いて得ら

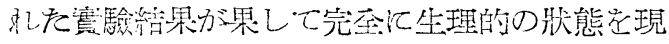
クしているかに゙らか一應憸討する必要注西る。

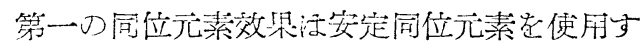

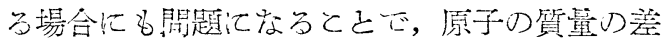

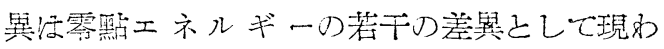
れ，礼方影響して來るような現象，例えば吸着，

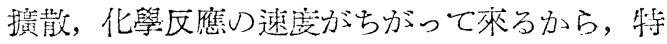

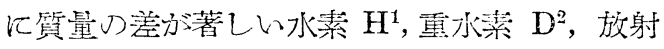

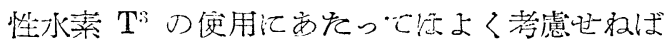
なら茨的。濃厚な重水汇上り生物が基しい賃害

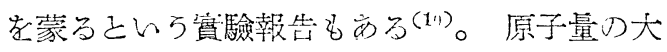

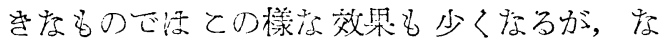

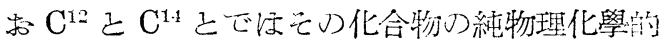
反應速度に 3 8\% 程度》美が西るといわ柇て

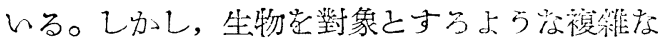

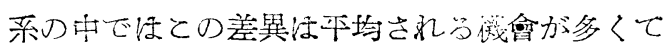
大して現わ礼て來ない之考允ら礼万。

第二の放射線效果注無視出來度いことで，例 えば大量の放射性燐を注射しを動物つ藏器つ燐 化合物つ交替度が少量注射つものに比して抑元 ら礼ているといら例も亦る(11)。どつ位使光ば安
全かといらてと注實驗の種類によらので，現在 までその點を調べたデータが極めて少い故何上 も斷言出來ないが，出來るだけ少量索使用与る よう實驗を計畫すべ登で市る。甚しく精密を定 量的福驗索す万場合を除いて注，てれだけの 注意で充分で亦万ら。

\section{應 用 の 種 類}

\section{1. 物質の移動及び分布}

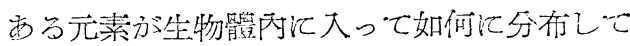

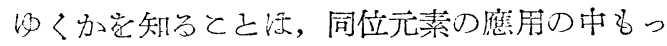
之も簡易で，もっとも有效な場面である。

例えば放射性鐵 $\mathrm{Fe}^{59}$ 惁犬にの恋也，一定時

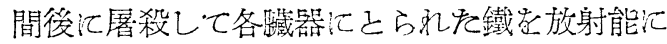

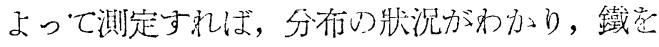
酸溶性のるの之, 非酸溶性のるのに分けて浿万 と上子出來方。二礼汇上って少量つ鐵つ吸收率 岂も知り得万のであって，之ほ從來の方法で汪

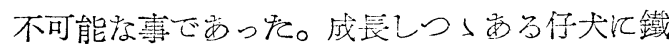

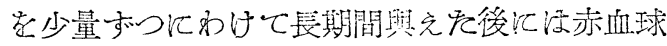
にほ勿論入るが，筋肉化るミオグロビンとして

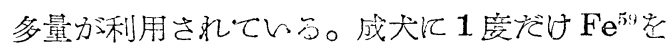

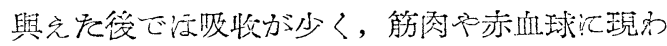

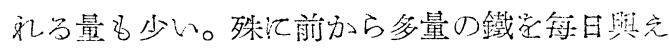
ていた犬で活鐵の吸收注少く，吸收されを驖も

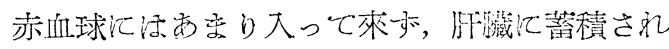

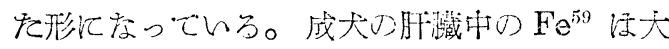
部分非へミン鐵に存与万(12)。晹力方吸收さ礼

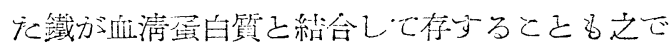
明瞭汇さ能た

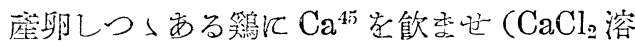

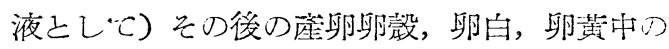
$\mathrm{Ca}^{45}$ 及で排泟物中の $\mathrm{Ca}^{45}$ 家測定して見っ之,

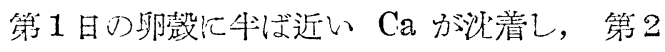
日,第3 日之 $\mathrm{Ca}^{45}$ の沈着汪急激飞減少与方。與

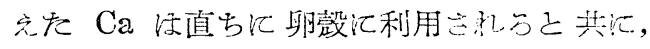

(10) H. G. BARBour and J. Trace: J. Pharmacol., 58 (1936), 460.

(11) J. Lawrence, L. W. Tuttle and L. A. ERF: J. C'. Invest., 20 (1941), 577.

J. H. Lawrence: J. A. M. A., 134 (1947), 219.

(12) P. F. HAHN and 吉川: 醫學と生物學, 1 (1942), 53.

吉川: 同 誌., 1 (1942), 185.

(13) H. Yoshilawa, P. F. Hahn and W. F. Bale: Proc. Soc. Exp. Bio'. Med., 49 (1942), 285. 
大きな部分が文速かに排泄されることがての實 驗で明がされた。卵白及び卵黄中汪僅が

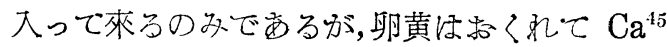
の存在量が增えて來ることが見られ，之行卵黄 內で卵黄が急激任生成しつ小西る間任投與さ礼

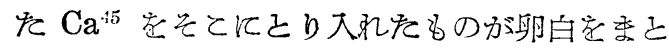
い，卵款索つけて生れ出ていたてと示してい $3^{(1:)}$ 。

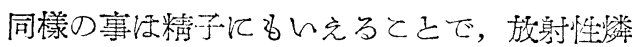

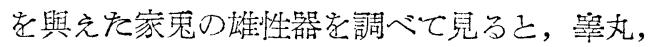
精霬液, 前立腺に注早くから $\mathrm{P}^{32}$ が現われる が，翰精管內容に任 5 日目に $\mathrm{P}^{32}$ が最高化改 ると己活精子分形成される時 $\mathrm{P}^{23}$ 老とり大れ， それが輸精管江現われるまで時がか子る故之思 われる。副礐丸から輸精管を通って來ろのに20 日位かつるといらととが墨汁等老使用した觀察 で從來いわ秃ていろから，ての實驗汸翰精管內 容の精子のみ在分離与る之か, 兰の酸非溶性燐

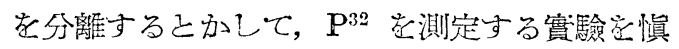

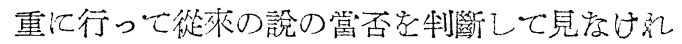
ばなら思思う(15)。

燐注比放射能が甚笑高いから，との上ら学員 驗が行い円すいが，比放射能の高い同位元素学

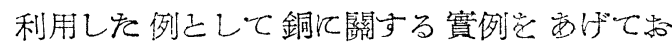
く。ニッケルルプロトンを西て〉(サイクロトロ ン利用)つくった $\mathrm{Cu}^{61}$ 《比放射能力゙非常化高い から，牛減期が短い（12時間）飞る拘わら方銅 の吸收實驗汇利用出來る。犬凯量で法西るが

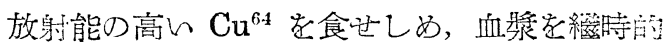
に探取してそのま」カウンターにかけ㣗ば，銅 の化學的分離它行らまでる度く，與えた銅つ

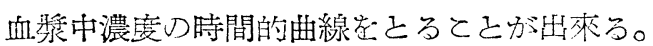
こらして，銅汇血漿中汇食後1時間位で最高に

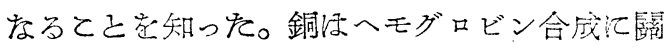

與しているてとがわかっているが，溜血区復に よって貧血狀態に置いた犬のへモグロビン生座 量と赤血球中に現われる $\mathrm{Cu}^{64}$ の量と分本行す るここがての實驗でわかった。䳆血してい㦄い 犬でも唄血から恢復したばかりの犬で注, 赤血 球中に現的秃る $\mathrm{Cu}^{6.4}$ 方比較的多い(16)。細胞の 透過性学知万弓という場合沉, 內外の同種イォ ン間の交換老知るこ己注舊來の方法で注全く無 力で西るが，外側のイオンを放射性同位元素で

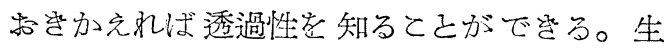

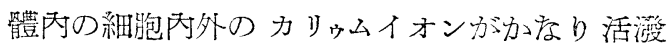
に交替しているととが制明し夲のる $\mathrm{K}^{42}$ 然利 用しをからで西った。

放射性同位元素，例元ば $\mathrm{P}^{32}$ 者同化させを virus, 細菌, 細胞等它つくり, その移動索追究 する研究子可能である。

\section{2. 稀釋による物質量の測定}

例えばこ〉蛋白質の加水分解物があり，ア ミノ酸 $\mathrm{A}, \mathrm{B}, \mathrm{C}$.......量老标かりをかっをとす る。るしもA存るアミノ酸行同位元素家含有せ しめをものA*死つくり, その一定量学このア ミノ酸混合物江混合儿, 後, ての.アミノ酸

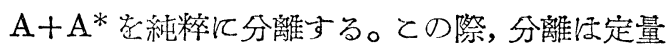

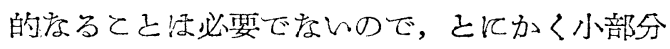
でよいから、Aをるアミノ酸学分離す机ばよい ので亩る。A 未知箽学 $\mathrm{x}$ ，加えた $\mathrm{A}^{*}$ の量孝 $\mathrm{y}$ ，

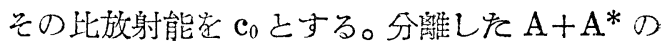
比放射能 $\mathrm{c}$ 老測定す机ば,

$$
\begin{aligned}
& \mathrm{c}=\frac{\mathrm{y}}{\mathrm{x}+\mathrm{y}} \mathrm{c}_{0} \text { であるから } \\
& \mathrm{x}=\mathrm{y}\left(\frac{\mathrm{c}_{0}}{\mathrm{c}}-1\right)
\end{aligned}
$$

でAの量が求められる。之が所謂 isotope dilution analysis である(1i)。 $\mathrm{N}^{15}$ 孛入れたアミノ

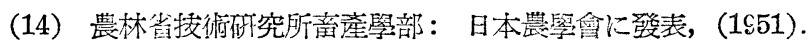

$$
\text { " : " , (1951). }
$$

* 以下說明を簡單にするため, 比放射能を嚴密に當該元素の比放射能の意味でなく, 假に RA の單位 質量の放射能の意味にする。稘つ比放楌能に元素の原子量×原子數と RA の分子量との比を乘じた ものが假の比放射能で㐫る。

(16) H. Yoshikawa, P. F. Hahn and W. F. Bale: J. Exp. Med., 75 (1942), 489.

(17) D. Rittenberg and G. L. Foster: J. Biol. Chem., 133 (1840), 737.

(18) A. S. KESTON and M. LEVY: 私信による. 
酸は現在アメリカでは市販されるまでになって レるので, 之がしばしば利用されている。

この場合には未知量 $\mathrm{x}$ は添加量 $\mathrm{y}$ の少くとも $1 / 5$ 以上はないと正確な結果洼得ら難い故,被 檢物の量がかなり多くないとよくない。

b 万一つの難點は同位元素を含む $\mathrm{A}^{*}, \mathrm{C}^{*} \ldots$ …の特に比放射能の高いるのを合成せねばなら ぬととにある。上述のアミノ酸の場合には光合 成を行い得る硫黃バクテリアを $\mathrm{C}^{14} \mathrm{O}_{2}$ の存在の 下に培食して, 後菌體から蛋白質をわけ, 加水 分解して個々のアミノ酸を分離してつくる方法 がある(18)。

被檢物の方同位元素を入れて, $\mathrm{A}^{*}, \mathrm{~B}^{*}, \mathrm{C}^{*}$ ……とし，之にAを既知量加えて分離精製し， この比放射能を測るといら inversed dilution analysis の方法がある。 $\mathrm{A}^{*}$ の比放射能 $\mathbf{c}_{0}$, $\mathrm{A}+\mathrm{A}^{*}$ の比放射能を $\mathrm{c}$ とすれば

$$
\mathrm{x}=\mathrm{y} \underset{\mathrm{c}}{\mathrm{c}-\mathrm{c}}
$$

co老充分に高くし，x に比べ y を大きくす そば $\mathrm{x}=\mathrm{y} \frac{\mathrm{c}}{\mathrm{c}_{0}}$ 。

この方法で注被檢物の比放射能さえ高けれ ば，それに應じて被檢物が微量で足るし，A， B等桠普通の化學的純品を使用すれば足る。乙 加し， $A^{*}, B^{*} \ldots \ldots$ 同位元素を導入し, ᄂか子 乞の比放射能を知って必要がある。細菌と か小動物之かの生體成分ならば同位元素を相當 長時間與えて, 全身のその元素の比放射能が 平均した時を見計らってての inversed dilution analysis 沈仔るという方法もある。と の種の方法に屬するもので, 成功したるのに isotope derivative method がある(19)。

てれ忹，放射性同位元素を含む試藥 $\mathrm{R}^{*}$ をつ くり，之を $\mathrm{A}, \mathrm{B}, \mathrm{C}$........定量的に反應させて $\mathrm{R}^{*} \mathrm{~A}, \mathrm{R}^{*} \mathrm{~B}, \mathrm{R}^{*} \mathrm{C}$.......をつくり，之洁活性の $\mathrm{RA}$ 孝添加して $\mathrm{R}^{*} \mathrm{~A}+\mathrm{RA}$ 老純粹に分離する のである。式は上と同じよらにしで

$$
\mathrm{x}=\mathrm{y}\left(\begin{array}{c}
\mathrm{c} \\
\mathrm{c}_{0}-\mathrm{c}
\end{array}\right)
$$

及注 $\mathrm{x}=\mathrm{y} \quad \mathrm{c}$

で表わされ， $\mathrm{c}_{0}$ は $\mathrm{R}^{*}$ の比放射能で與えられ るから，問題が簡單になる。

アミノ酸分析の pipsyl method が之で, $I^{131}$ para-iodophenylsulfonyl (pipsyl) chloride 試藥

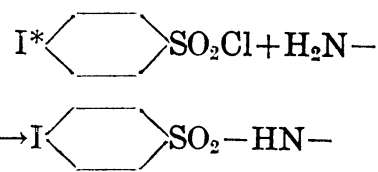

とし，アミノ酸のアミノ基に定量的に化合させ るので西る。 pipsyl-amino 酸は counter current method, 西るいほ partition chromatography で分別精製する。

てっで R*A+RA の比放射能 $\mathrm{c}$ 专しく知 らなければならない筈であるが, dilution methodを使って之をさける吅妙な方法が Keston によって考案されている。それは分析のために 添加する RA のアミノ酸 A 飞 $\mathrm{C}^{14}$ で目印をつ けるので西る。 $\mathrm{C}^{14}$ で目印をつけるの注前述の よろに硫黄バクテリアの光合成でつくることが 出來る。 $\mathrm{R}^{*} \mathrm{~A}+\mathrm{RA}$ * の中 $\mathrm{I}^{131}$ 己 $\mathrm{C}^{14}$ と牧放射 線のエネルギーに大差があり, 牛減期にも大差 があるので，之によって $\mathrm{I}^{131}$ と $\mathrm{C}^{14}$ とを分別 測定するととは容易である。A* の比放射能を $\mathrm{c}^{\prime}{ }_{0}, \mathrm{R}^{*} \mathrm{~A}+\mathrm{RA}^{*}$ の $\mathrm{C}^{14}$ の比放射能存 $\mathrm{c}^{\prime}$ とす る之 $\mathrm{c}_{\mathrm{i}} \mathrm{X}=\mathrm{c}(\mathrm{x}+\mathrm{y})$ $\mathrm{c}^{\prime}{ }_{0} \mathrm{y}=\mathrm{c}^{\prime}(\mathrm{x}+\mathrm{y})$

故任 $\quad \frac{\mathrm{c}_{0 \mathrm{x}}}{\mathrm{c}^{\prime}{ }_{0 \mathrm{y}}}=\frac{\mathrm{c}}{\mathrm{c}^{\prime}}=-\frac{\mathbf{a}}{\mathrm{a}^{\prime}}$

但し, 分離純化した $R^{*} A+R A^{*}$ の $I^{131}$ ( $\mathrm{R}^{*} \mathrm{~A}$ による) の放射能を $\mathrm{a}, \mathrm{C}^{1 *}\left(\mathrm{RA}^{*}\right.$ に由來 する）の放射能を $a^{\prime}$ とする。これで paper chromatograph のような方法で化學的には定 量し得店々程の微量の $\mathrm{R}^{*} \mathrm{~A}+\mathrm{RA}$ *分别した 場合にるAの量が測定し得るととになる(2ii)。

以上のべを, 同位元素の移動, 分布の追究及 び稀釋分析法の二つが tracer としての利用の

(19) A. S. Keston, S. Udenfriend and M. Levy: J. Am. Chem. Soc., 69 (1947), 7151,

(20) A. S. KESTON and M. LEVY: 私信による. 
基礎で，てれから述るのはとの若干の應用面で ある。

\section{3. 物筷分嚾の罵の標識}

混合物質中より，ある特定の物質を分離する 場合，比放射能力゙高い同物質の少量当添加して から分劃老行い，放射能を目印としてその物質 がぞの分劃に出で來るかを見て，物質分離の目 安とする行き方で西る。イオン交換樹脂で稀土 類元素を分離するのに之が利用されていたが， 生化學方面では蛋白質の加水分解窟物をイオン 交換樹脂で分離する場合飞利用されている程度 であるが，生體成分の分離に有力な方法で，應 用值價が大きい。との一つの應用とすべもの にペーパークロマトグラフィーのオートラジオ グラフィーによる分離汇同位元素を利用する 方 法が西る。

\section{4. 中間代謝の研究}

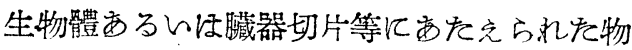
質が，途中いかなる變化を經て終末髉物にまで 到達するかとんう, 中間代謝の研究に同位元素 を目印として物質汇附けるといら方法によって 大きな進步を示しを。刎論同意元素を利用して る解決の望みのない問題注無限汇西り，同位元 素萬能の如を考えを持つととは許されないが， 現在ての利用によって萑來想像されていた理論 が否定されたり，重大な改訂を受けをものが少 くない。

生物體內の成分 B が果して何から出來るか, 前循物質 precursor 老知了場合飞威力孝發揮 する。近頃になって明確になった1例に鳥類の 窒素代謝終末原物なる尿酸の前驅物質の研究が 西る(21)。尿酸の構造上尿素2 分子及び乳酸の上 万店 3 炭素化合物から合成されるといらのが從 來の想像說であるが, 種々の化合物の炭素及び 窒素汇同位元素它入れて沜に與えを實驗の結 果, グリココル1分子, 蟻酸 2 分子, $\mathrm{CO}_{2} 1$ 分 子, それに代謝プールから由來する $\mathrm{N}$ が 3 個 つんて出來上るととがわかっを。核酸中のプリ ン體も之と同じ形式で出來るといわれ，蟻酸が
2 の位置行大るこき位ovorum factor が必 要なのだそん万(22)。

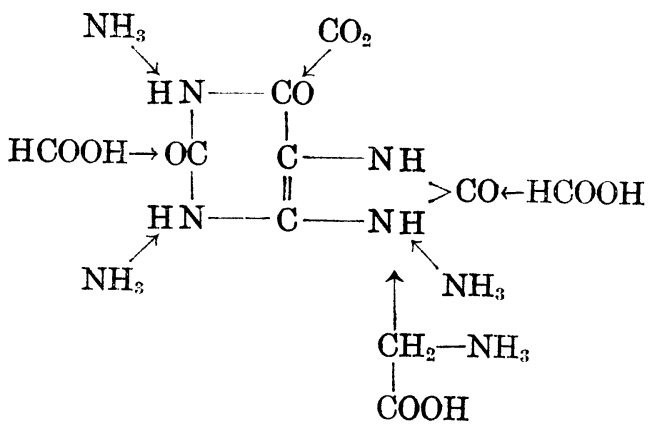

$\mathrm{A} \rightarrow \mathrm{B} \rightarrow \mathrm{C}$ な万變化過程がある己を，もしb Bが反應しきすんため江1過性汇少量生和るの みで補捉出來ないてとが西る。その時柱この系 飞同位元素点む $\mathrm{B}^{*}$ 字加えてやる。Bが $\mathrm{B}^{*}$ 己混合すれば，西る時間後再分離した $\mathrm{B}^{*}$ が唏釋 されているから，之でBの存在岩確認出來る。

$\mathrm{A} \leftrightarrows \mathrm{B}$ なる應が可逆反應であっでる平衡恒 數が右方へ極端汇かたよっている場合には普通 の分析方法でほ可逆性㱏知り得ない。ての時は 反應系汇同位元素付の $\mathrm{B}^{*}$ 考加えて反應させた 後，A者分離精製し，その中に同位元素が大。 て來ていれば，ての反應ほ可逆性だったここに なる。

複雜な反應系で, 反應系列が一つの輪廻をな しているときは可逆でなくさも，日゙を加えたた めに $\mathrm{A}^{*}$ の中同位元素が入って來るこいらと とは旸論あり得る。<smiles>[R]1C[Te][Te]1</smiles>

\section{5. 物筫代謝活性度の研究}

同位元素索使用したをめに明確になった生物 學上の基礎的原理注，所謂動的平衡の原理であ 万丂。

從來汪動物體の構成物質はそれ程速く分解す ることはなく，食物は主としてェネルギーの供 給源としての意味をるち，構造の減耗岚補充す るために極く少量の食物成分が關與するのみゲ

(21) J. C. Sonne, J. M. Buchanan and A. M. Delluva: J. Bio!. Chem., 173 (1948), 69;

J. M. Buchanan, J. C. Sonne and A. M. Delluva: ibid., 173 (1948), 81.

J. M. BUCHANAN：私信による. 
と考允ら礼ていた。とてろが同位元素が生物學

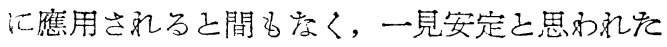
身體構战物質が非常交速さで合成分解总行って いて，構成元素加活溇汇交替 turn-over してい

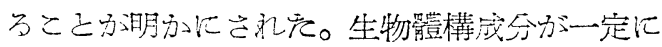
保を礼ているの社, 綃局, 合成反應, 分解反雇

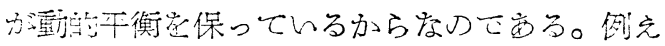

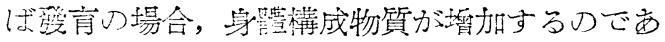

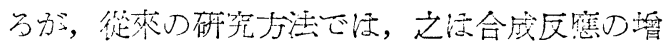

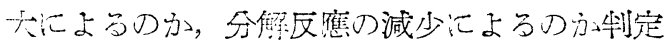

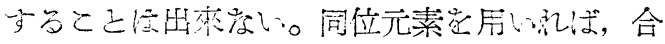

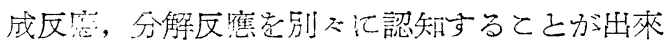
るので，ての間題空解法するの汇最もすぐ礼た 道具で㐫万。

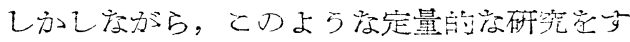

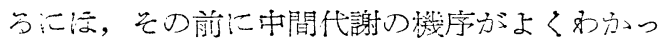

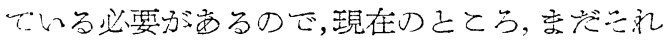

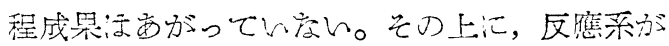

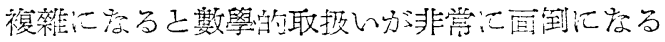

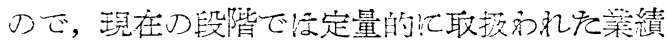

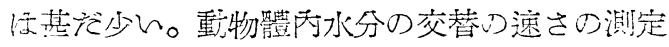

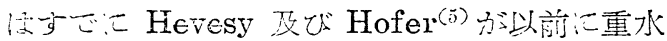
总使って行っている。最近 Rittenberg 等(23) 注

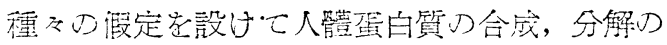
速さの計算起行っている。

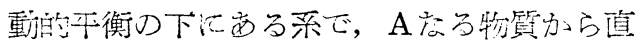
接B原万物質が出來るととがわかっている場 合， $\mathrm{A}$ の比放射能の時間的變化と BD只礼之D 比較から， $\mathrm{A} \rightarrow \mathrm{B}$ の反應の速さ空數學的汇求め

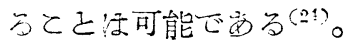

$\mathrm{p}=\mathrm{A}$ がB江多行する速さ（一定）

$\mathrm{r}=$ 組織內つ $\mathrm{B}$ の量（一定）

$\mathrm{x}=$ 組織內の $\mathrm{B}^{*}$ の量 (變化す万)

$f(t)=$ 時刻 $t$ に和けるAD比放射能

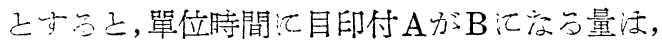
p. $\mathrm{r}(\mathrm{t})$ で目印付 $\mathrm{B}$ が消失してゆく量泟 p. $\mathrm{x} / \mathrm{r}$, 故にBD比放射能つ時間的變化汪,

$$
\frac{d z}{d t}=p \cdot f(t)-p \frac{x}{r}
$$

r忹一定で西るから，之書をかえて

$$
r \underset{d t}{d t}=p_{\left(f(t)-\frac{x}{r}\right)}^{x}
$$

つ委り $\mathrm{r} \times(\mathrm{B}$ の比放射能つ毅化 $)=\mathrm{p} \times(\mathrm{A}$ の 比放射能一Bの比放射能)

そいら關係が西る。之によって A. B 兩物質の 比放射能つ變化抽線力ら turn-over rate の

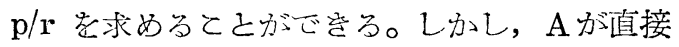

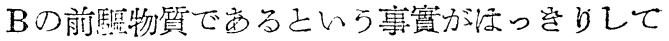
いる場合泟少いし, 時間的江 $\mathrm{A}$ 上 B cの比放射 能老多數測定与ってとの因蜼さから之はなかな かむ呩しい。

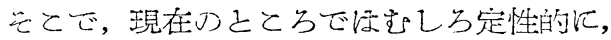

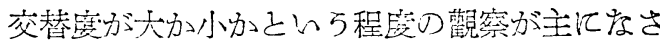

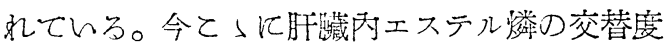
に䵖与る實驗索例示する。

白鼠飞 $\mathrm{P}^{32}$ 老微量の $\mathrm{NaHPO}_{4}$ の形で注射し， 一定時間後江屠殺しで肝臟內無耧燐及び酸溶性 エステル橉の比放射能在測定する。い秃の分 割のP \& 血清つP と不斷汇交替しつ」西るわけ

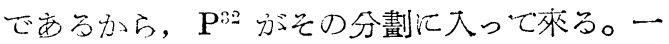

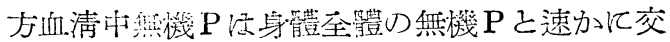
替するから，此效射能活速力汇低落す万。それ

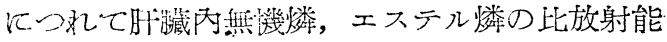

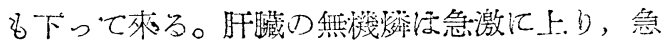

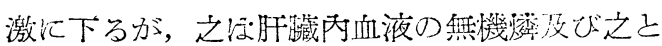

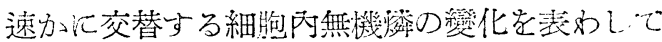

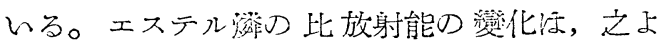

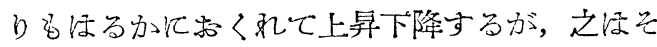
の交替がや小出そいてとを示している。コリン 缺乏沉陷った鼠と正常の鼠とで，酸溶㤬エステ 儿养の比放射能を比べて見ると，コリン缺乏て 注てのもの〉交替度が小さくなっているととが わかる。

との重豶力ら，しかし何故沉コリン缺乏でエ

(23) D. B. Sprinson and D. Ritteneerg: J. Biol. Chem., 180 (1949), 715.

(24) D. B. Zilversmit, C. Fntenman and M. C. Eishler: J. Gen. Physio'., 26 (1943), 323. D. KAMEN: Redioactive Tracers in Bio'ogy, 2 Ed., Academic Press Inc., New York, (1051).

（25）春日：日本生化學會關東部㓱，(1951)。 
ステル粼の交替度が下るか上いらて上むせぐ沉

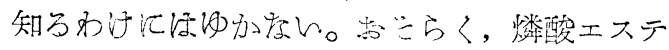
儿化の減退汇よるものと思われるけ礼を゙も，變

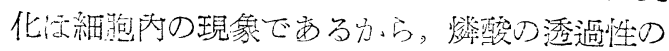

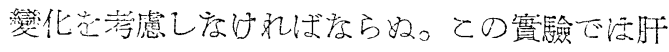
藏の䧆機燐の比放射能が兩群のラッテで略に同 じで亩らから，透過性汇注變化がなかっをと見

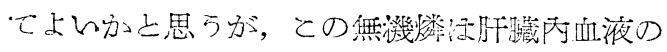

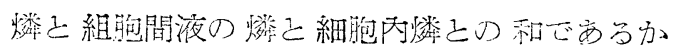

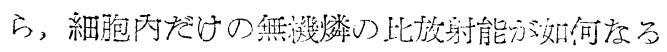

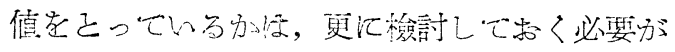

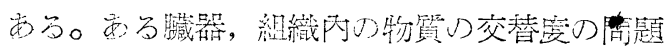

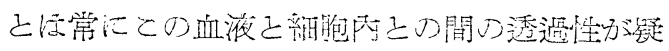

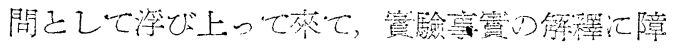
碍已去々と上が少く索々。

\section{結詇}

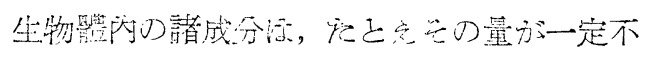

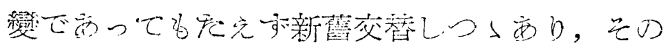

結果一つの動的平衡狀態壳保っていらのであ る。こ颂が生物體の維持の根本汇橫倇わる原則 でとのような觀點に立つので学け秃ば物質代

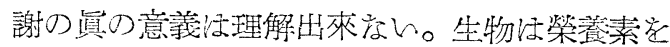

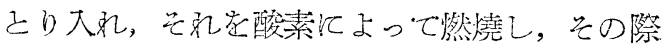
遊離するェネルギーを利用しているわけで方る が，從來の鲎基學では熱力學第一洼則にのみ根

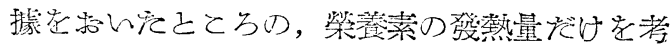
えで，そのエネルギーの中，利用可能のエネル

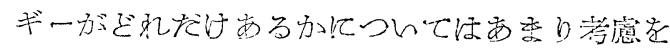

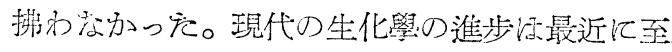
b，熱力學第二法則它物質代謝の塔察に上り大

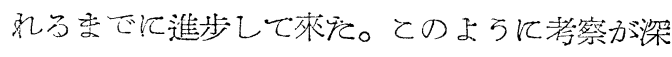

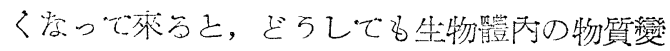

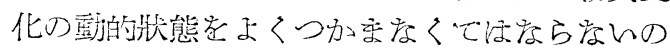
であって，同位元素の利用がての部門に重要店

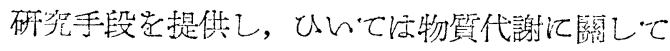

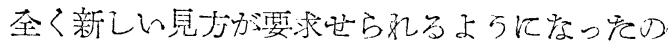
でする。 


\section{第二日（8月 25 日）午媵}

\section{動 物 實 驗}

東京女子醫大教授（東京女子醫大,生化學敉室）

松村 義 寬

全動物葆使う RI 實驗に限定する。從って灌 流實驗, 組織切片, ホモグネート, 酳素標品汇對 するるの注述べをい。全動物を使用する資驗の 目的は大體次の如く分類せられるで西らう。

（1）物質の利用, 吸收, 排泄

この中には動物體全體に對しての場合の 他飞各種臟器への吸收又は排泄, 從って生 物學的の牛減期の測定等名含まれる。

（2）物質の各器官, 組織への分布狀態 静的の觀察の他飞動的存方面, 師ち代謝 貯槽の大をさの測定が合まれる。

(3) 中間代謝の經路の研究

てれには中間代謝産物の同定, 轉變の順 序，turn-over の速度等の測定。

(4) 物質の輸送, その經路及び速度

（5）放射能の生物江及ぼす影響

上記の目的を達するをめ亿 RI 劣使用する時

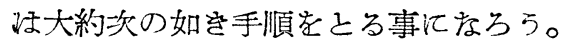

(i ) 標識化合物の合成

(ii） 標識化合物の被檢動物一の導入

(iii）動物體上り目的物の採取

（iv）被檢化合物の分離,精製

（v）分離,精製された化合物中の被檢原子 の分別

（vi） 標識 RI 原子の定量

簡單なモデル實驗汭んて，

てれ等の要點を說明する。

實驗 例 1 筋肉中に $\mathrm{NaHP}^{*} \mathrm{O}$ ，を注射しを 場合の $\mathrm{P}^{*}$ 》排泄之各獩器への分布

（1）體重 $200 \mathrm{~g}$. 內外のネズミに體重 $100 \mathrm{~g}$. あたり1.5 筋中飞注射する。代謝籍中に於て，屁尿を採取 乙得万如くして，24特間後にとり出し庼尿注別 そに分けて計數皿中にとる（尿の場合は一定の 容積汸すめて各 $1 / 30$ 量をとる)。殺して, 各
臟器を分ける。心, 肺, 肝, 腎, 脾, 脺, 胃, 腸, 生殖 器, 腦注各別の計數血、飞, 筋, 骨, 皮及び注射部 位の下肢は各別に肉挽にて細碎して計數皿に大 れる。

（2）計數血沉とった組織はなるへく均等の 厚さになる如く平滑に抑え伸ばし，組織の重量 から (4) 飞述べ方法依る自己吸收の補正が 出來るよらとする。

(3) 注射汇用い它のと同じ $\mathrm{NaHPO}_{4}$ 溶液の $1 / 100$ 量を别の計數皿にとり乾燥する。との皿注 放射能の測定時汇常に對照として測定し, 計數 器の能率の變動, RI の壤變等の補正に用い る。

（4）（3）之同じもの, 郎ち注射に用いた量 の 1/100 量の NaHPO: の大った計數皿乾燥し たものに $0.1 \sim 5 \mathrm{ml}$. の蒸溜水老逐次加えて, 測定を行って圖の如き曲線安得る。てのグラ フルより睵器の放射能の吸收が水の元れ之等し く, 又臟器の比重子水之等し几と見做好ば, 臟 器の自己吸收の補正が出來る。

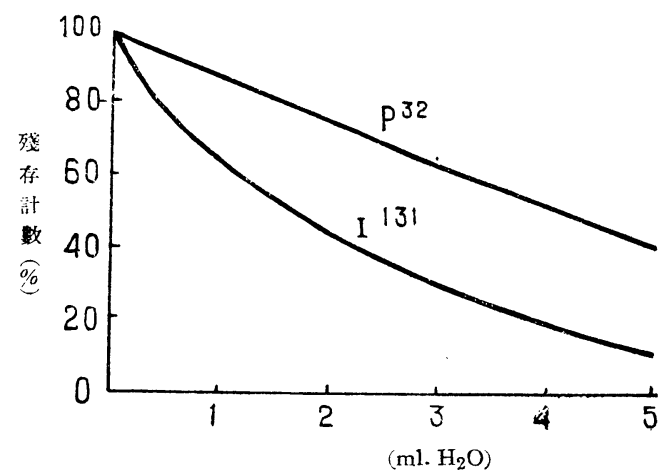

(5) 適當极測定器 (Lauritsen 型檢電器, G-Mカウンター）汇より各計數皿上の $\mathrm{P}^{*}$ 量孝 測定する。

(2)，(1）により作った標品を500〜800 
電氣爐で燒灼して灰化して後て測定する。この 場合，骨，屎以外の自己吸收の補正は不要亡な る。

實驗 例 2 沃度の各臟器への分布之甲狀腺 中のThyroxin 劃分中への出現

（1） ネズミに沃度イオンの形で $\mathrm{I}^{131}$ を 1.8 $\times 10^{1} \mathrm{c} / \mathrm{min}$ 注射し, 4 時間後红殺す。例 1 の場 合の如く處理する。但しての場合注特に甲狀老 完全:て分離して別の皿にと万。例 1 (2)，(3)，(4), （5）に從って測定する。Iの大部分が甲狀腺に

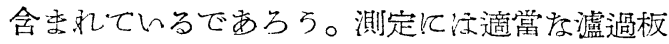

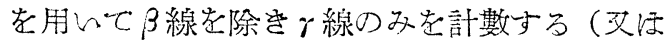
シレチレーション，カウンターを用いる)。

（2）甲狀腺より沃度化合物の分離 全甲狀腺索 $2 \mathrm{~N} \mathrm{NaOH} 20 \mathrm{ml}$. 江溶解与る。 キャリアーとして乾燥甲狀腺末 $10 \mathrm{mg}$. を加之, 蒸氣浴上に24特間置き，完全江溶解也しめ，蒸 墢した水補い $20 \mathrm{ml}$. と妳し, その中 $0.5 \mathrm{ml}$. 考計數血にとる。T

$5.0 \mathrm{ml}$. 古ブタノール5 $\mathrm{ml}$.を用いて浸出点 2 回 行い，浸出液在合して气の $1 \mathrm{ml}$. 在計數皿に之

万。W

ブタノール浸出殘液 (水溶性部) に活 $3 N \mathrm{H}$ Cl $5 \mathrm{ml} ., 2 \% \mathrm{KJ} 1 \mathrm{ml} ., 1 \% \mathrm{KJO}_{3} 1 \mathrm{ml}$. 孝加元 る。 $\mathrm{I}_{2}$ が遊離するから $\mathrm{CCl}_{1} 10 \mathrm{ml}$. 亿て浸出を 2 回行 $\backsim \mathrm{CCl}_{1}$ 艺合して, $0.1 N \mathrm{Na}_{2} \mathrm{~S}_{2} \mathrm{O}_{3}, 0.1 N \mathrm{Na}$ $\mathrm{OH}$ の $10 \mathrm{ml}$.で $\mathrm{I}_{2}$ 孝イオンに變じて轉溶し，そ

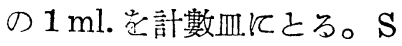

$\mathrm{S}, \mathrm{T}, \mathrm{W}$ 乾燥（低溫で）して測定する。

$$
\begin{aligned}
& \mathrm{S} \text { イオン型ョード } \\
& \mathrm{W} \text { サイロキシンョード } \\
& \mathrm{T} \text { - }(\mathrm{S}+\mathrm{W}) \text { ヂョードチロジンョード }
\end{aligned}
$$

實 驗 例 $3 \mathrm{C}^{14}$ 醋酸の生體內酸化之肝グリ コグンへつ轉化

Radioisotopes, 2 (1953), 11〜21. 在參照された wo

（7）動物實驗における RI の投與量在決定 するに當って最少量汪實驗の稀釋度, カウンタ 一の能率等で定められるが，最大量注放射線障

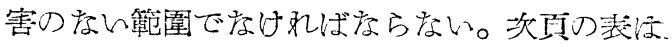
寥教になる゙交らら。

\section{苶考}

M. D. KAMEN: Radioactive Tracers in Biology, 2 Ed. (1951), Academic Press. J. H. LAWRENCE and J. G. Hamilton: Advanees in Biological and Medical Physics, 1 (1948); 2 (1951), Academic Press. Melvin CALvin et al.: Isotopic Carbon, Techniqnes in its Measurement and Chemical Manijdalation, John Wiley \& Sons, (1949).

V. A. Bertram Low-BeER: The Clinical Use of Radioactive Isotopes, (1950).

C. C. Thomas: Symposium on the Use of Isotopes in Biology \& Medicine, Univ. of Wisconsin. Press, (1949). 


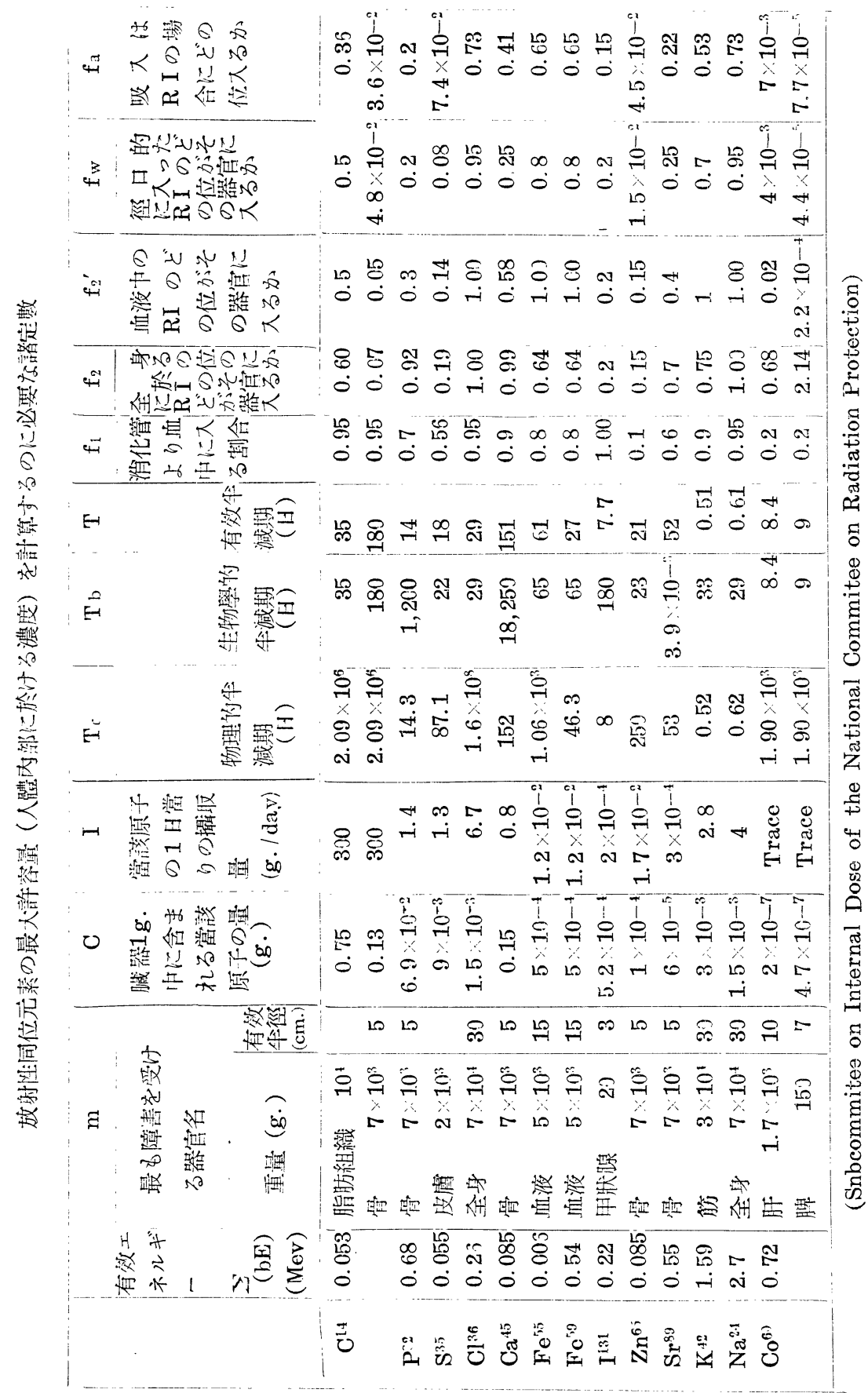




\section{放射性同位元素をトレーサとして生物反應に應用した例}

東大，農藝化學科 丸 尾 文 治

放射性同位元素を トレーサーとして用い禃 物, 微生物の代謝汇ついて東大農藝化學科で行 わ秃を研究二・三を紹介する。

\section{1. 植物體を用いた例}

水稻を水㸷液で培養した後草丈 $50 \mathrm{~cm}$. 位, 根長 $18 \mathrm{~cm}$. 位沉なったとき第 1 圖の如き容器 机汇入っ。

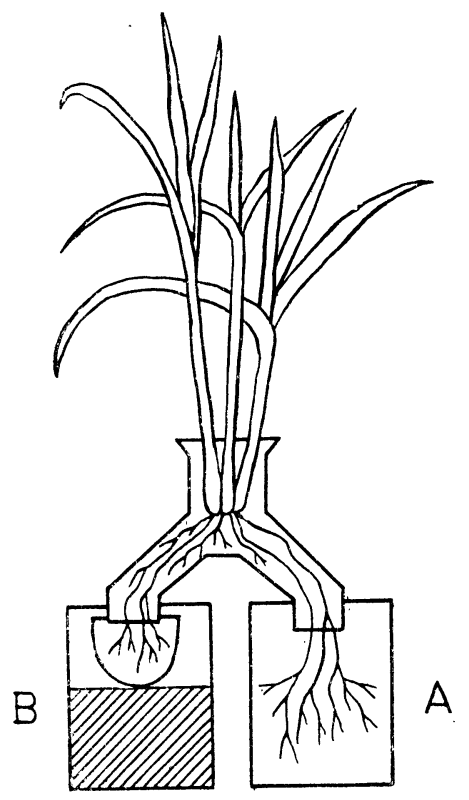

第 1 図

$\mathrm{A}$ の容器に $\mathrm{P}^{32}$ を含む水耕液を大れ， $\mathrm{B}$ 亿 ほ蒸留水, 燐酸缺乏水耕液或的正常水耕液を 入れて 6 日間培㑢した. A の中にはN $40 \mathrm{ppm}$ $\left(\mathrm{NH}_{1} \mathrm{NO}_{3}\right), \mathrm{K}_{2} \mathrm{O} 30 \mathrm{ppm}(\mathrm{KCL}), \mathrm{CaO} 20 \mathrm{ppm}$ $\left(\mathrm{CaCl}_{2} \cdot 2 \mathrm{H}_{2} \mathrm{O}\right), \mathrm{MgO} 20 \mathrm{ppm}\left(\mathrm{MgCl}_{2} \cdot \Delta \mathrm{H}_{2} \mathrm{O}\right)$, $\mathrm{P}_{2} \mathrm{O}_{5} 3 \mathrm{ppm} \quad\left(\mathrm{Na}_{2} \mathrm{HPO}_{4} \cdot 12 \mathrm{H}_{2} \mathrm{O}\right), \quad \mathrm{Mn}_{2} \mathrm{O}_{3}$ $1 \mathrm{ppm}\left(\mathrm{MnCl}_{2}\right)$ の他 $10 \mu \mathrm{c}$ の $\mathrm{P}^{32}$ を正燐酸の 形で加える。B の液は時及取替えて蒸發乾涸し

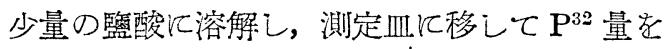
測定する。乞の結果ね第I表の如くで西った。
第 I 表 $\mathrm{P}^{32}$ の放出量

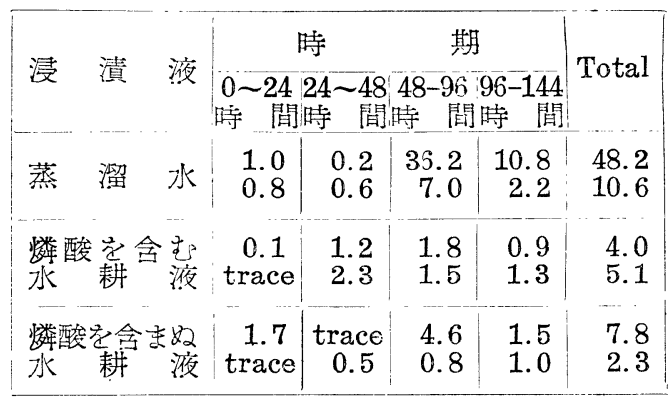

144. 時間後楦物體を上く洗って植物體中の $\mathrm{P}^{32}$ の量攰測定した。乞くに $\mathrm{P}^{32}$ に浸漬したお の根と $\mathrm{P}^{32}$ 拿まない容器飞浸漬した方の根汇 つんて测定した結果老第 II 表に示す。椬物體 中の $\mathrm{P}^{32}$ の測定には灰化した後測定した。

第I表で見られる如く水稻の根から僅かで西 るが $\mathrm{P}^{32}$ の放出分亦るのが知られる。例數が少

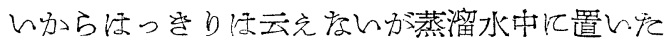
るのがや小大をく，他の2區について殆ど差が 認められ教い。礼放出がイオン交換作用で 出て來るので度をいと思わ秃る。カチォンの場 合には，溶液中沉カチオンが存在するとてれ之 交換して放出されるので, 蒸溜水中机秃をも のよりカチオンを含む液江大れたもの小方が放 出する量がずっと多いてとが屡及見られる。燐 酸の場合に注との上ら度イオン交換作用で放出 されるのでね存んと思われる。蒸溜水の場合汇

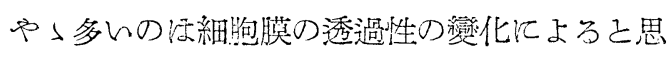

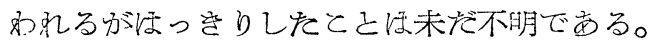

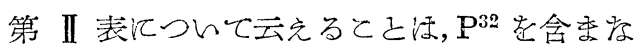

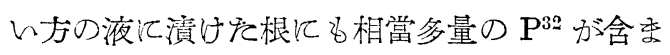
れ，燐酸を含む液に漬けたものでも $\mathrm{P}^{32}$ が相當 含委れている。てのて之は根から吸收されを燐 酸が上に上っで行くばかりでをく，同時に下降 するものも西る。上昇下降兩作用が根の中で同 時汇起っているととを示す。又若い根の部分住 


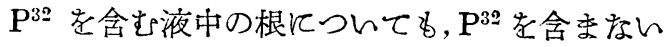
液中つ根につんても同樣に $\mathrm{P}^{32}$ 含量が高い。て のととはとの他の場合にもよく見られるとと
で, 若い生長の盛な部分では, 燐酸その他の成 分の動きも盛で代謝が旺盛であるととがよく分 る。

第 II 表 根の中の $\mathrm{P}^{32}$ の分布

\begin{tabular}{|c|c|c|c|c|c|c|c|c|c|c|}
\hline \multirow{3}{*}{ 浸 } & \multirow{3}{*}{ 漬 } & \multirow{3}{*}{ 液 } & \multicolumn{2}{|c|}{ 放 } & & 根 & \multicolumn{3}{|c|}{ 吸 } & 艮 \\
\hline & & & \multirow{2}{*}{ 若い根 } & 古 & 根 & \multirow{2}{*}{ 全 量 } & \multirow{2}{*}{ 若い根 } & \multicolumn{2}{|c|}{ 古 い 根 } & \multirow{2}{*}{ 全 量 } \\
\hline & & & & 上 部 & 下 部 & & & 上 部 & 下 部 & \\
\hline \multirow{2}{*}{ 蒸 } & \multirow{2}{*}{ 溜 } & \multirow{2}{*}{ 水 } & 41.3 & 16.1 & 16.3 & 3148 & 44.6 & 43.4 & 50.1 & 11985 \\
\hline & & & 62.9 & 29.4 & 13.4 & 5584 & 121.7 & 69.6 & 57.1 & 24619 \\
\hline \multirow{2}{*}{\multicolumn{3}{|c|}{ 燐酸定含屯水耕 液 }} & 59.0 & 11.4 & 19.2 & 4168 & 93.9 & 44.6 & 87.4 & 23005 \\
\hline & & & 45.2 & 14.9 & 21.5 & 3411 & 70.1 & 32.1 & 43.1 & 14647 \\
\hline \multirow{2}{*}{\multicolumn{3}{|c|}{ 粼酸を含ま奴水耕液 }} & 27.8 & 14.5 & 28.0 & 5251 & 83.8 & 43.0 & 66.4 & 28827 \\
\hline & & & 45.1 & 11.2 & 25.1 & 4868 & 60.4 & 39.9 & 43.1 & 15706 \\
\hline
\end{tabular}

全量は測定した根全體につき div. $/$ sec. $\times 10^{4}$

その他については乾物重 $1 \mathrm{mg}$. 當りの div. $/$ sec. $\times 10^{+}$

\section{2. 微生物の代謝の研究に用いた例}

土壤から分離した Psudomonas 屬心細菌で酒 石酸をよく分解する菌汇ついて，酒石酸がぎの よら竣路で分解するか在研究した例で西る。 この菌嫌氣的な條件下で大略, 3 酒石酸 $=2$

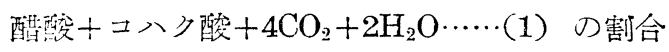

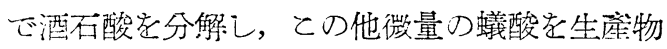

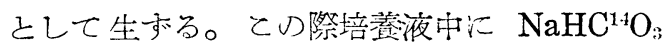
を大れておくよ $\mathrm{C}^{1-1}$ が酉石酸汇少量，コハク酸 に大量大万が醌酸汇忹全く大らない。蟻酸注 $\mathrm{CO}_{2}$ と平衡した specific activity を示す位入 るととが明がになた。コク酸中の specific

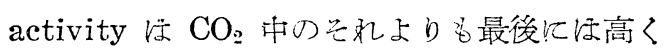

なる程である。

酒石酸中の $\mathrm{C}^{1-1}$ 注 $\mathrm{COOH}$ の部分㲹入ってい. る。コハク酸中の $\mathrm{C}^{14}$ \& $\mathrm{COOH}$ の $\mathrm{C}$ 亿っ ていて $\mathrm{CH}_{2}$ 中の $\mathrm{C}$ には大っていないととが 分った。炭酸ガスを放出する反應であるにるか. 小方示,一方の生成物(コハク酸) 中汇注非常 亿多量の炭酸ガスが培養液中から入って行き, 他の一つの生成物（醋酸）には全く入らない之: 云ら極めて興味深い現象が見付かっ它。その他 の實驗結果も考慮して，ての菌汇よる酒石酸の 分解過程注第 2 圖の上万杍もので㐫万ら己推定 される。

酒石酸の各炭素江印䘮附したものを作って基.

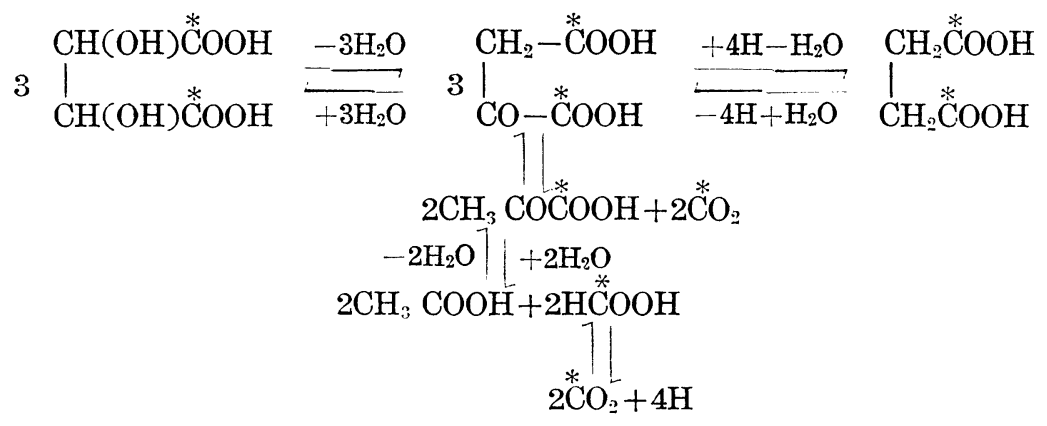

第 2 圖 
質にして的ばよく分万筐であるが，そのよう なるの方仲出來ない。こらいう場合にるとの 例で海簡單存 $\mathrm{C}^{1.1} \mathrm{O}_{2}$ 孛培養基汇入机ただけで $\mathrm{C}^{1.4} \mathrm{C}_{2}$ が都合よく代謝福路汇入って行った爲, 多くの解析在行らこ之が出來をわけで㒸る。

\section{3. 燐酸エステル化反應に應用した例}

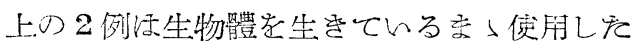

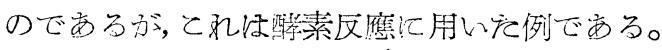

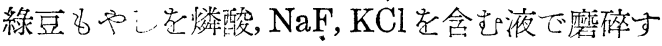
ると醉素混合液上なる。的酸素つ存在する 所でよく振渻すると酸素索吸收し， $\mathrm{CO}_{2}$ 老放出 すると同時江無機燐酸が急速汇減少するという 現鱼が見られる。この際どのようを燐酸化合物

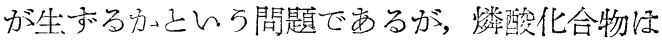

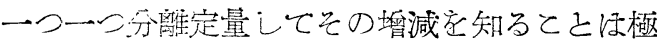
めて困蜼で, 現在の所不可能で品る。乞てでての

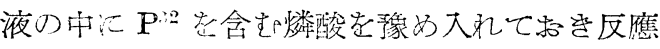
させ，反應終了後トリクロ酒醋酸を加えて反應

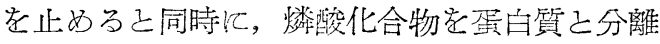
乙抽出する。抽出液在分别し各劃分汇ついて P, $\mathrm{P}^{32}$ 量老测定すると同時飞濃縮してペーパーク ロマトグラフにかげる。展界液としてほイソプ ロパノール, イソブタノール, conc. $\mathrm{NH}_{4} \mathrm{OH}$, で 40:20:1:39 のもので先汇展界し, 次ん
水イソプロパノール, トリクロル 醋酸, cone. $\mathrm{NH}_{i} \mathrm{OH}$-水 75cc.: $5 \mathrm{~g} .: 0.3 \mathrm{cc} .: 25 \mathrm{cc}$. の割合の 液で二次限に展界する。ての滤紙にモリブデン 酸アンモンの酸性溶液を噴霧し, 乾燥後殺菌燈 で照射する之燐酸化合物の存在する所に青色几 發色する。殆ど總ての燐酸化合物が發色するか

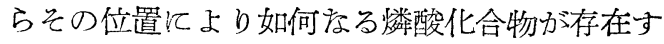
るか柱判明するわけで，ての場合には，無機燐 酸, hexose-phosphate, hexose-diph:sphate, phosphoglycerate, phytin 等の存在すると こが見られた。ての濾紙を更に，X線フィルム 之重祊て（間汇セロファン紙を1枚大れれ方が

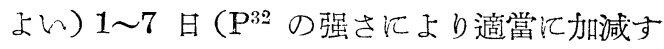
る）放㯰した後フィルム崖現像すると, $\mathrm{P}^{32}$ の大っ ている部分のみが感光しているから，上の反應 で拱機燐酸から生成した化合物が制るかけであ る。ての例で注 hexose-phosphate, hexosediphos-phate, phosphoglycerate $\sqrt{ } \mathrm{C}^{2}$ 多量 の $\mathrm{P}^{32}$ が入っでいたが, phytin にほ全く大 っていないてとが明か江度った。 phytin の生 理的意義が他の化合物之全く暴るととが推定さ れる。又ての研究の副產物之して從來廣く行わ れている燐酸化合物の分別法が不完全で㐫るて こが判明した。 


\section{第一日（8月24日）午前 \\ オートラジオグラフィー}

\section{O 序 \\ オートラジオグラフィーは標本中の放射性同} 位元素の分布, 郎ち存在する位置之量之者寫眞 乳齌膜中に衭錄する技術である。 オートラジオグラフィー (autoradiography) ほまを，ラジオオントグラフィー（radioautography）とるいう。オートラジオグラフとは，

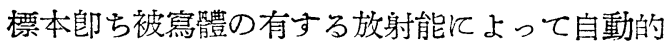
飞得られを放射線寫真(radiograph) 老意味し, ラジオオートグラフとはとの放射能によって得 られを標本の自畫像（autograph）の意である 亏。

\section{1 原理, 種類及びその特徵}

放射性橉を含む肥料䘮耕作物佂與える之，根 上り吸收され礼放射性燐酸は放射性考有さない 通常つ橉酸肥料之同一飞行動して稙物體內江分 布してゆく。その葉索採取してて礼を $\mathrm{X}$ 線フィ ルムを密着させておく。葉の中に分布した放射 性燐注常崩壤して 3 線老放射している。X線 フィルムの寫買乳劑膜活々の $\beta$ 線を吸收して, 放射性燐飞接してい万部分江感光する。從って フィルム現像すると、葉の中に分布していた放 射性燐飞對應した部分注黑く現像されるが，そ の他の部分飞注黑化汪みられない。のように 乙て得たフィルムがオートラジオグラフであり， こ齐と葉とを比較對照すれば，燐は葉のぼの部 分佰集中するか者知るととができる。放射性燐 索與えてから一定時間每飞試料索とってオート ラジオグラフを作れば，燐の移動が時間的にん かと行われるかを追跡するととがでをる。放射 性同位元素の位置ほオートラジオグラフの黑化 位置で定めることができるし，その量泟黑化濃 度によって知るてとができる。比較的大きな標 本中の分布を肉眼で觀察でをる程度の乳劑膜の 黑化と乙て記錄し，放射性同位元素の位置は乳
富士舅福フィル矿究所 古 關 靖 夫

劑膜の黑化場所, その量汪黑化濃度として測 定するのが Survey Autoradiography 又は Macroautoradiography である。

顯微鏡的孛標本中の分布茬寫真乳劑膜中飞記 錄し, 相當高倍率の顯微鏡下で觀察し, 又注顯徽 鏡寫真を撮影して，現像された銀粒子の存在す 万位置で放射性同位元素の位置者，現像銀粒子 の數でその量を決定するのが Detail Autoradiography 又活 Microautoradiography で ある。

まをを線志よび 3 線の飛跡索利用する方 法るある。乙れは特に飛跡オートラジオグラ フ (Track Autoradiograph) 已呼ば礼る。放 射性元素より放射される $\alpha$ 線や $\beta$ 線は寫這乳 劑膜を通過与ると，その經路に沿ったハロら゙ン 銀粒子を現像可能汇する。從って現像後穎微鏡 で見ると，1列汇並んで現像銀粒子師ち $\alpha$ 粒子 や $\beta$ 粒子の飛跡が見られる。cの飛跡の交點は 郎ち放射性元素の存在位置学示し，飛跡の數汉 その存在量つ測度となるのである。この方法の 大きを特徽位置它定める精度がよく, 誤差汪 數ミクロン程度である點である。

このよう汇寫貪乳劑膜光用いて放射性元素の 分布を決定するオートラジオグラフの技術は， 他の放射能測定方法に比べて次のよら学特徴を 有している。

（1）放射性元素の微細な分布狀態を知り得 る。

（2）標本と對照した分布圖が容易に得らる。

（3）その測定結果の記錄忹牛永久的である。

（4）存在位置の測定精度が著しく良ん。

（5）放射能を時間的飞積分できるから, 檢出 能力が著しく高い。

（6）宇宙線， $\gamma$ 線及び硬 $\mathrm{X}$ 線の影響を比較 的受计店的。

（7）操作簡便で, 特殊な實驗裝置定必要こし 
ない。

\section{2 歴史とその應用}

\section{$2 \cdot 1$ 歷史}

オートラジオグラフ技術の歴史は, 1896 年 江 Becquerel が放射性元素老々の放射線比 よって寫眞乳劑が黑化する事實から發見したて 己住始っている。そして 1911 年沉 Wilson が簿箱を發明するまで竄真乳劑が放射能測定 つ唯一の手段であった。

オートラジオグラフ惊 Ra p Thのよう存天 然放射性同位元素老含生鍉物岩石の研究江應用 己れ, 動稙物體內の天然放射性元素の分布狀態 を知るの汇用いられてをた。

近年になって，人工放射能の發見によって人 工放射性同位元素が墢見されて，人工放射性同 位元素を用いるオートラジオグラフは 1938 年 Groven, Govaeuts 及び Guéven 等が $\mathrm{P}^{32}$ を用

んて實驗したのと始まった。

その後, 原子力工業の蕉展に伴へ,アメリカと つ他で原子爐气の他の元素變換裝置から，各種 の放射性同位元素が多量飞製造さ礼るよらとな った。放射能を目印として各種の元素及びてれ 老含む物質を追跡する研究方法が急速江進步普 及したので，てれ伴ってオートラジオグラフ の技衡㤬，鑛物學，岩石學以外飞冶金學，動物 學，植物學，醫學，化學，農學等の分野江急速 江隼用範圍が廣がり，最近で注更江工學的應用 当行わ机ている。

\section{$2 \cdot 2$ 適用出來了放射性同位元素}

原理的にはいかをる放射性同位元素儿對してて も適用出來るわけであるが，その牛減期!上っ て適用できない場合もある。

オートラジオグラフの操作に纺若千の時間を 要するから，牛減期が分や時間の桁の放射性同 位元素汪，標本を作り露出に大る前に既に大部 分の放射能方失われて了らので，オートラジオ グラフを作るとこができない。牛減期 12 時間 の $\mathrm{I}^{13.1}$, 平減期 14 時間の $\mathrm{Na}^{2.4}$ が半減期の短
几方の限度である。

反對に，牛減期が長い放射性同位元素では， 試料中の濃度が相當高くないと，相當長い時間 露出してもオートラジオグラフが得らない場合 がある。例えば牛減期 $10^{6}$ 年の $\mathrm{Cl}^{36}$, 牛減期 5,500 年の $\mathrm{C}^{14}$ 等活試料中相相當高い濃度で存 在していないとオートラジオグラフを得るとと が難しん。との際, 標本切片学厚くして, たる え得られをオートラジオグラフの解像力は低下 しても, 標本中の放射性同位元素の面積濃度花 上げる必要がある。

丁度適當疗卅減期老有していて，比較的容易 にオートラジオグラフ娄作るととのできるもの 起第 I表得擧げておく。

第I表 オートラジオグラフに䢛した 放射性同位元素

\begin{tabular}{|c|c|}
\hline 放射性耑位元素 & 半減期 (日) \\
\hline $\mathrm{I}^{131}$ & 8 \\
$\mathrm{P}^{32}$ & 14 \\
$\mathrm{Sr}^{89}$ & 35 \\
$\mathrm{Fe}^{59}$ & 44 \\
$\mathrm{~S}^{35}$ & 87 \\
$\mathrm{Ca}^{45}$ & 180 \\
\hline
\end{tabular}

\section{$2 \cdot 3$ 應 用 例}

前述の如くその應用注急速に撗大しつ小西る が，て】て恬富士オートラジオグラフ感光材料 字用いて本邦於で得られを成果の一端及びそ の他老紹介与るとととする。

\section{2・3-1 醫學, 生物學方面への應用}

（1）吉田肉腫細胞

名古屋大學 醫學部日比野敉授指導の下汇柴 橋，三輪，福井の三氏が擧げられた成果で㐫 $3^{(1)}$ 。

吉田肉腫学移稙してから 4 日後, 鶃飞 $0.25 \mathrm{mc}$ の $\mathrm{P}^{32}$ 孝注射した。注射後 9 日目に死んだ鼠の 骨䯣液を富士オートグラフ乾板 ET-2E 型に塗 抹し，急速に乾燥した。100日後*，乾板范メ夕 ノール中に 3 分間浸漬して固定してから, D-19 現像液を用いて $18^{\circ} \mathrm{C} に \tau 4$ 分間現像し，定着，

(1) The Nagoya J. of Medica? Science, 14 (1951), 79.

*ここ場合 100 日の露出の必要はない。「6・1 露出時間の決定」の項參照。 
水洗, 乾燥した。次いで感光膜上の標本をギム ザ染色した。

染色した細胞に焦點苍合吨て撮影した顯徽鏡

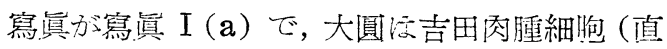
徑 $30 \mu$ )，小圓法赤血球（值徑 $7 \mu$ ）である。寫

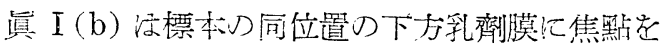
合过て撮影した同倍率の顯微鏡寫黃であって，

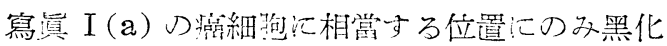

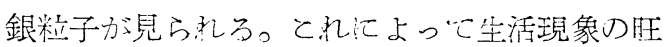

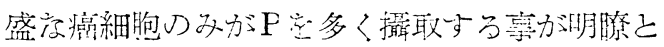
存った。

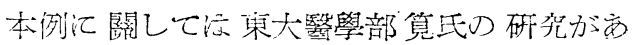
3 (a)

(2) Paramecium caudatum（ジウリムシ) 京部六學理學部植物學敎室で新嫁敉授の指導 の下心平岡助呚授, 石田, 杉山氐等刀得られた 成界つ 1 例である(引)。

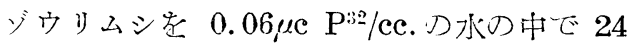

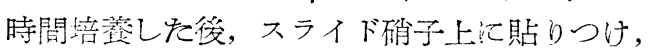
固定した。水わ中で富士オートラジオグラフ・ ストリッピング乾板 $\mathrm{ET}-2 \mathrm{E}$ 型上り剝膜した乳

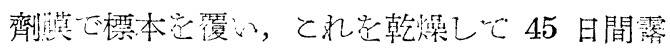
出してから，D-19 現像液で $18^{\circ} \mathrm{C} 2.5$ 分現像 處理し声。

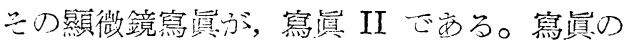
中央の大圓の黑化甚しい部分注大核 (Macro nucleus）心，左方數個の小圆狀の黑化の甚しい

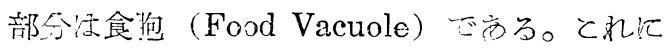
よっで 24 時間 $0.05 \mu \mathrm{c} / \mathrm{cc}$. の $\mathrm{P}^{32}$ にて處理し

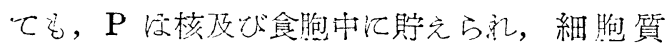
(Cytoplasm) 亿相賞量存在するとさがわか ๖。

（3） Trillium Smallii (延鉧草) の䔲の斷 面

京都大學理學部植物學敎空で新家敉授, 平岡 助敎授, 石田及び杉山氏鼠げ゙成果の一つで
ある(3)。

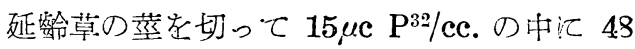
時間切花式に處理した後, 固定脫水後, 切片点 作る。乙礼还スライド硝子汇貼付け，富士オー トラジオグラフ乾板 ET-2E 型と密着してて 36 日露出徯, D-19 現像液行て $18^{\circ} \mathrm{C} 2.5$ 分現像し

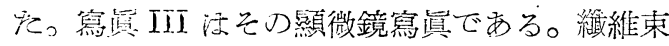
(Vascular Bundle) 江Pが多く分布し, 无の 內，木部 (Xylem) の方が穊部 (Phloem) より

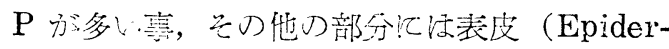
mis）以外分布してないことが見ら礼る。

（4）䐄㵴汇沛着したトロトラスト

東大箵學部中泉郄授の指導の下汇筧, 杉村, 中尾氏 ${ }^{(-1)}$ 证 11 年前搒斷の目的でトロトラスト $\left(\mathrm{ThO}_{2}\right.$ のコロイド溶液）老靜胍注射し，膽管癌

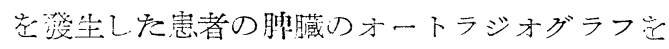
作った。 組織侸パラフィン包埋, $5 \mu$ つ切片之 し, 染色後七口イジン膜点か讨, 只の上老下下 リッピング乾板より得膜しを乳劑膜で覆い，乾 燥冷暗虎汇放置しを。气して現像して得をるつ

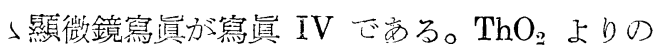
几線の飛跡が組織綝より出ているのが見える。 郎ち飛跡オートラジオグラフの1例でする。

（5）家患の甲狀腺

大阪市立大學輻學部放射線科中塚助教授等が 得ら机を成果の一部で西る(5)。

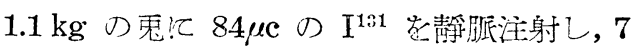
日後江甲狀踩孛剔出した。10 の切片在り，富 士オートラジオグラフ乾板 ET-2E型を用いて Mounting Method \& Stripping Method $K$ よってオートラジオグラフ岩作った。寫黄 V

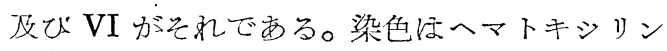
・エオシンを故长。

ての實驗條件で注東芝製ガイガー・ミューラー 訃數管（? 線用）方用いた場合，訃數之露出時 間乞の關係注第 II 表に示した如くであった。*

(2) 筧 弘㲔：日本醫學放射線學酉誌，12 No. 4 (1952)，62.

(3) 新家浪雄: 放射性问位元素講劦俞䄇義集 (京都大學)，(1952)，1７.

(4) 中泉, 筧, 杉村, 中尾：日本醫學放射線學會誌，12 No. 4 (1952)，62.

（5）中塚，他：日本醫學放射線學會炤和 28 年總會講演，(昭 28. 4. 7.).

* 「6. 1 露出時間の決定」の項參照。 


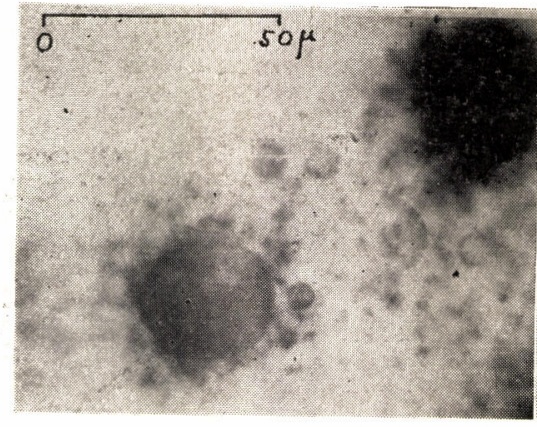

(a)

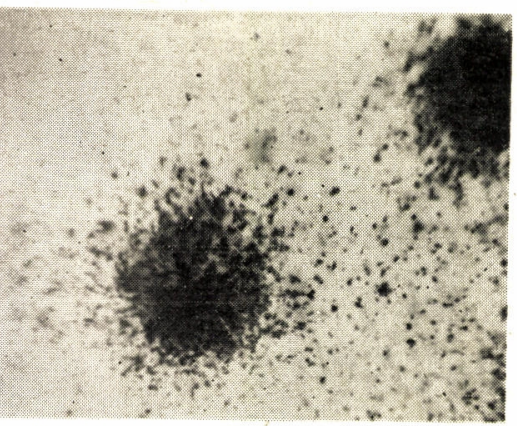

(b)

寫覓 1. 吉田肉腄細胞中の $\mathrm{P}^{32}$ のオートラジオグラフ

(a.) 細胞に焦點を合せた寫覓

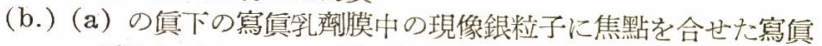
(富上オートラジオグフフ乾板 $\mathrm{EP}-2 \mathrm{E}$ 型使用)

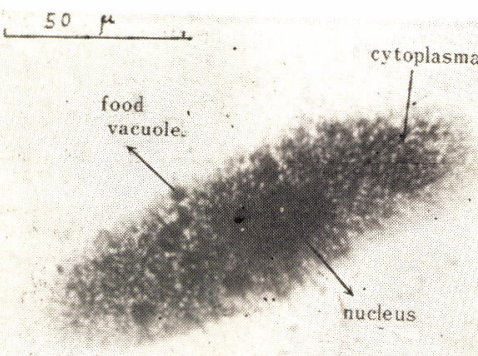

寫真 2. ゾウリ蟲中の $\mathrm{P}^{32}$ のオートラジオグラフ (富上オートラジオグラフ・ストリッピング乾板 ET-2 E 型使用)

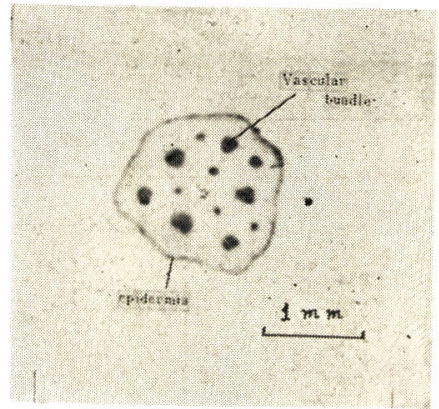

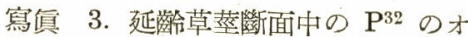
ートラジオグラフ

(富上オートラジオグラフ乾板 $\mathrm{ET}-2 \mathrm{E}$ 使用)

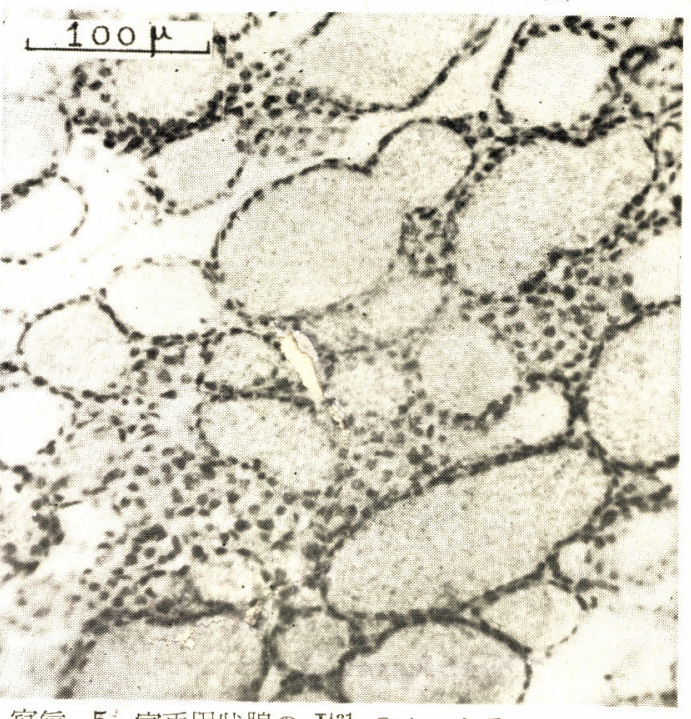

寫傎 5. 家电甲狀腺のI $I^{131}$ のオートラジオグラフ

(Mounting Method)

（富士オートラジオダラフ乾板 ETー2 E 型） 


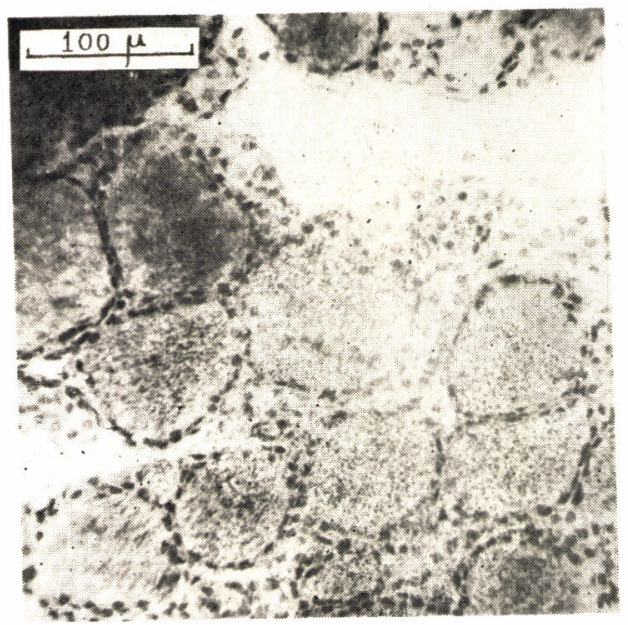

寫面 6. 家躳甲狀腺の $I^{131}$ のオートラジオグラ ᄀ (Stripping Method)

(富上オートラジォグラフ・ストリッピング乾板 $\mathrm{ET}-2 \mathrm{E}$ 型使用)

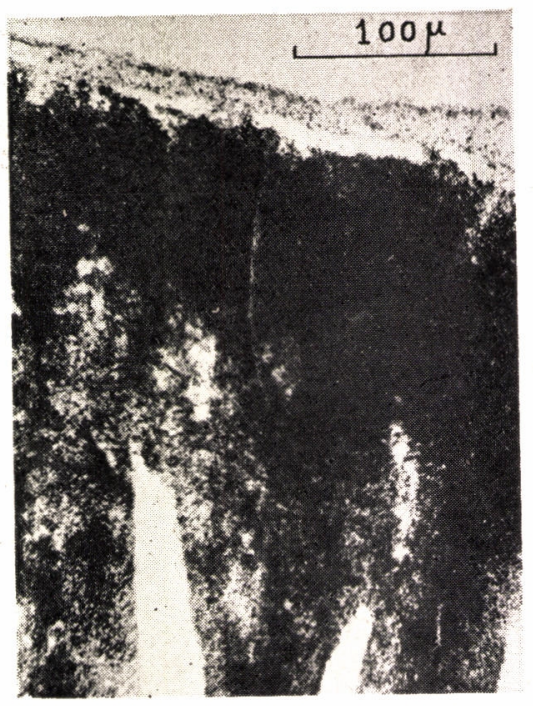

寫稹 7. Mouse の大腸 $\left(\mathrm{P}^{32}\right)$ (Mounting Method)

（富上オートラジカグラフ乾板 ETー2 E 型使用

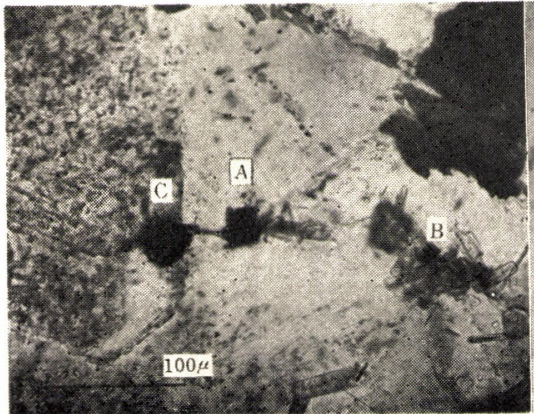

(a)

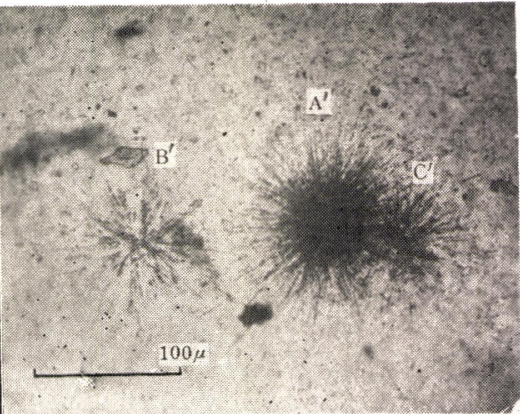

(b)

寫臱 8. 黑雲母 花崗岩中のピッチブレンドの飛跡オートラジオグラフ

(a.) 岩石薄片。 A, B, C はピッチブレンド

(b.) $\mathrm{A}^{\prime}, \mathrm{B}^{\prime}, \mathrm{C}^{\prime}$ は A, B, C よりの $\alpha$ 線飛跡の集合

(富上オートラジオグラフ就板 $\mathrm{ET}-2 \mathrm{E}$ 型使用)

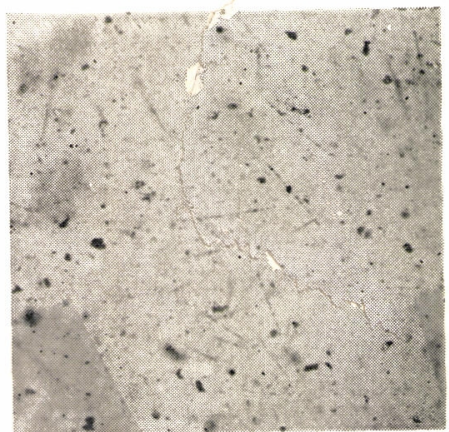

寫盾 9. エマネーション・カメラで記錄した ラドンの $\boldsymbol{a}$ 線飛跡オートラジオグラフ (富上オートラジオグラフ乾服 ET-2E 型使用) 
第 II 表 G-M 管計數と露出時間との關係 $\left(\mathrm{I}^{131}\right)$

\begin{tabular}{|c|c|}
\hline 計 數 $(1$ 分當り $)$ & $\begin{array}{c}\text { 同一程度の黑化を與える } \\
\text { 露出時間 }\end{array}$ \\
\hline 200 & $3 \sim 5$ 週間 \\
\hline 2,000 & 5 日 \\
\hline $5,000 \sim 10,003$ & 24 時間 \\
\hline
\end{tabular}

（6） 廿日鼠の腸

大阪市立大學殹學部放射線科中塚助敎授等の 發表 ${ }^{(6)}$ によると, 體重 $15 \mathrm{~g}$.の甘日鼠江 $275 \mu \mathrm{c}$ の $\mathrm{P}^{32}$ 表腹腔內注射後, 3 時間で腸管の切片を 作り (厚さ $5 \mu$ ), 富士オートラジオグラフ乾板 ET-2E 型老用い，Mounting Method で 2 r 月露出で得を結果が寫真 VII である。この時 の, 前項と同一條件での G-M 管計数注 10 20/分であっを。

本實驗之平行しで Stripping Method b行 ったゲ，染色操作中に， $\mathrm{P}^{32}$ が流出したらしく Mounting Method K比べて黑化無が低かっ を。

倘, 冤江 $3.6 \mathrm{mc} \mathrm{P}^{32} / \mathrm{kg}$. 老注射して 6 日後 に剔出した腸管を試料として 2 月露出で充分 黑化した。

\section{2・3-2 地質壙物學, 岩石學方面の應用}

（1）花岡岩中の微粒放射性鑛物

京大理學部早瀨氏 (i)（尔) 注瀨戸市雲興寺喾花 崗岩の岩石溥片製作途中で，カバーグラス在怔 りつける前の工程のものに，オートラジオグラ フ乾板应密着放置後, 現像處理した。放射性元 菜より出る $\alpha$ 線とよっで乳劑膜中经じを $\alpha$ 線

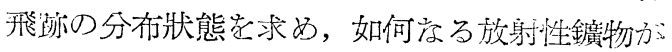
花崗岩中に分布しでいるか应沃定した。寫真 VIII は $\alpha$ 線飛跡汃放射狀に集合している 1 例 である。 $\alpha$ 線飛跡の長さから天然放射性元素の

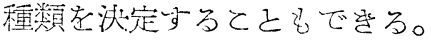

(2) エマネーション・カメラ

京大理學部初田, 早瀨氏 ${ }^{(9)}$ ほ京都市修學院の 花折斷譬が地質學的に通っでいる己推定される 地點（表土で覆われでいる）においでオートラ ジオグラフ乾板をエマネーション・カメラの中に 入れ，地中約 $1 \mathrm{~m}$. の梁さに適宜の間隔に埋める。 地中でカヌラの蓋安㐫ける。地下に次て放射

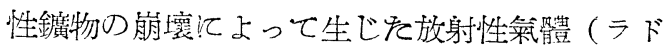
ン)のオートラジオグラフが得られる。郎ち 24 時間後, 地中ょり掘出しを乾板を現像し檢鏡す

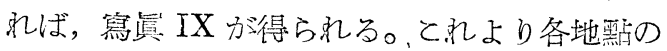
ラドンの分布狀態花知ることがでさる。最も多 く線飛跡が欟測された場所の下が，師ち斷層 の位置である。

\section{2・3-3 工業方面の應用}

工羙方面の應用注やっとその緒についたばか

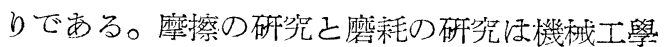
の大を放間題で西る。二つの金屬が相互に滑る 上, 一方の面上り微粒子狀態で材料か池の面に 移動する。ての時，一方の面に放射性同位元素

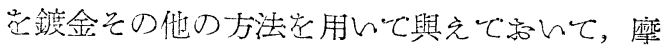
擦した後相手の面の放射能をオートラジオグラ

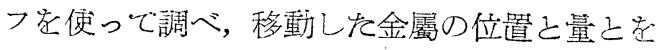
知ることができる。

RABINOWICZ ${ }^{(1)}$ 江潤滑油之油滑機構の研究に 本方法老應用して。

既耗試驗活非常化長時間岁要するが，放射性 同位元素定用いて極めて短時間に試驗できる。 例えば，エンジンのピストンリングの䐝用試驗 にとの方法茫用い，運轉後シリンダ一壁への金 屬の移動注シリンダー內壁沉オートラジオグラ フ用フィルム崖注り付けて測定する。同樣交方 法で, 工具圾ダイスの試驗の報告も歹る(11) ま をタイヤの試驗を $\mathrm{P}^{32}$ をゴムに加え・好絬果老 得ていろ ${ }^{(12)}$ 。

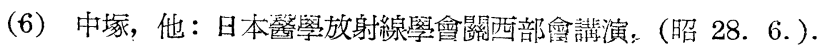

（7）早瀨一：科 學, 21 (1951), 422.

(8) " : 科學, 21 (1951)，543.

(9) 初 田: 私 信.

(10) E. Rabinowicz \& D. TABoR: Proc. Roy. Soc., 208 (1951), 455.

(11) M. Merchant \& E. J. Krabacher: J. Appl. Phys., 22 (1951), 150.

(12) G. H. Guest : Radioisotopes, Industria', App'isations. 
機我試驗所渡邊氏汪，軸承の燒われ部のオ一 トラジオグラフ党作るために，油の中に $\mathrm{S}^{355}$ 䀣濁させ，乙れに金屬部品を入れ加壓して研磨

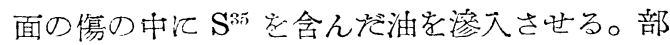
品直取出して表面の油老拭い去ってオートラジ

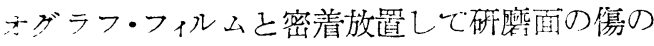
オートラジオグラフを得ている。

ホートラジオグラフ总用いると, 微量成分の

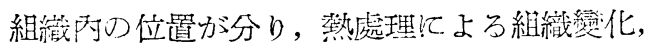
合金添加元素の分布，揢接棒成分の母材一の浸 入狀態，合金の㭙效等初研究されている。例充 ば，STANLEY によると,銅つ中へ $\mathrm{C}^{1 !}$ を入れて 熱處理してオートラジオグラフをとると，乾板 注一䅵江黑化しC汪一樣行分布しているととが

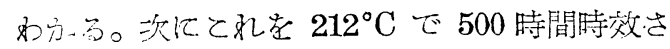

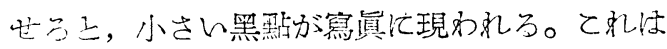
カーバイドの生成を示するのである。黑默の黑 化に時效時間で變化し，時效時間とカーバイド

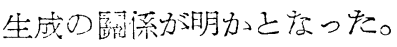

黑渏管栄株式會刑開田氏ほ，珪酸マグネシア 系而火燣瓦の成分 $\mathrm{Fe}_{2} \mathrm{O}_{3}, \mathrm{Al}_{2} \mathrm{O}_{3}$ 更び $\mathrm{CaO}$ が, 成型乙觉煉瓦老燒成爐中に積九で $1,400^{\circ} \mathrm{C}$ て

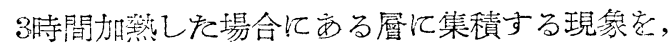

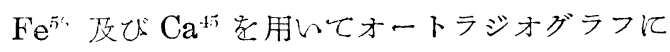
よって追跡卞方研究莸行っている。

融户繁鋼所の高橋, 永井氏ほ燒鈍しを鋼の組 織中の $\mathrm{P}$ の分布学, $\mathrm{P}^{32} 0.5 \mu \mathrm{c}$ 索 $1 \mathrm{~g}$. の銅に 添加して得を試料を $1 / 2 \mathrm{~mm}$. に研䐴してオート ラジォグラフ在とって研究中心゙ある。

ての他，ゴムやプラスチックの中へ放射性同

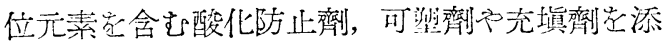
加して混和し，混和時間已共飞添加乵分如何な る布妝態で混和してゆくかをオートラジオグ ラフによって迫跡し, 最も經濟的に然時間に鼬

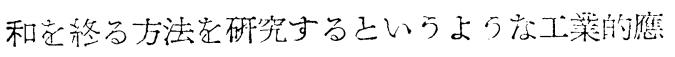
用它行我礼ている。

放射性闹位元素苦含む化合物りペーパー・ク ロマトグラム荙 $\mathrm{X}$ 線フィルと密着させ、放置後 現像すればそり展開され売爿態が X 線フィル

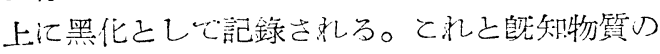

ペーパー・クロマトグラムとを比較するてとに よって，如何孛る化合物態として放射性同位元 素が移動したかを追跡することがでをるので， 廣く䐝驗手段として利用されている。

\section{3 解像力を決定する因子}

オートシジオグラフ技衡老適用なる場合に最 も注意し度け机ばならないてとは，いか比して 解像力学上く方力で西る。解像力方上い上云 万つは試料中刀放射性物質の存在す万範圍が兄 っくりこのまっ大きさで乳劑の黑化として記 錄されるととである。即ち，1點沉存在す万放 射性物筫江上って記錄される像がなる゙くはさ い面積を有するととが然むしい。解像力在決定 尔无子学次汇述へよ5。

\section{$3 \cdot 1$ 試料と乳劑膜との距離}

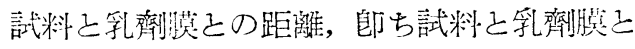
の密盖宾活解像力老卖眍する最重要因子である

Doniach と Pele (1:) 少理論的に計算した結

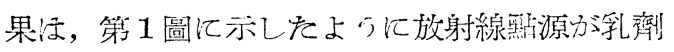
膜上り離れるに從って黑化する範囯方瀇がって 解像力淮下す方。

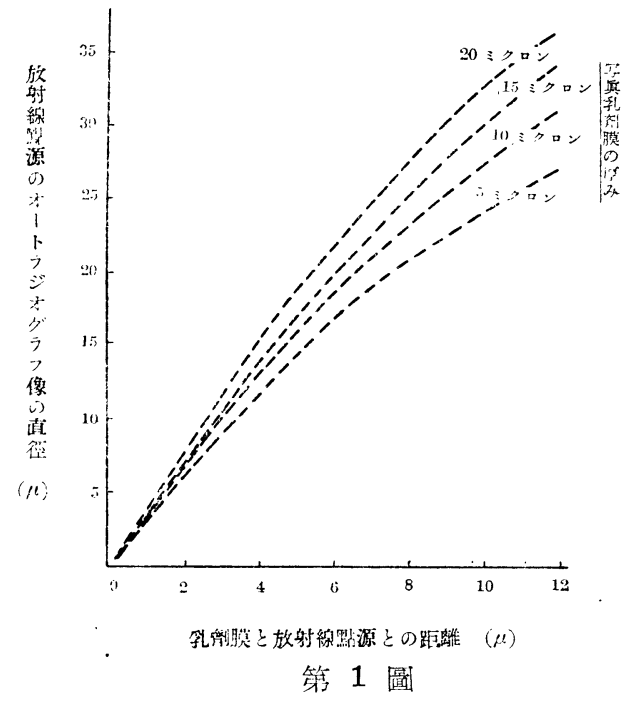

放射線點源のオートラジオグラフ像の直仼と乳䶒

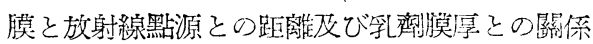

(13) D. Doniach and S. R. PelC: Brit. J. Radiology, 23 (1950), 184. 


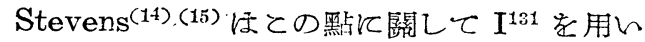
て實驗乙第血表の如き結果崖得ている。 第 价表 Stevens の實驗結果

\begin{tabular}{|c|c|c|c|}
\hline 乳剂 の種 類 & $\begin{array}{l}\text { 試料と乳 } \\
\text { 㰀膜との } \\
\text { 距離 }(\mu)\end{array}$ & $\begin{array}{l}\text { 解像 J } \\
\text { lines } / \mathrm{mm} \text {. }\end{array}$ & $\begin{array}{c}\text { 線の幅 } \\
(\mu)\end{array}$ \\
\hline \multirow{3}{*}{$\begin{array}{l}\text { プロセス乾板 } \\
\text { (Kodak Ltd.) }\end{array}$} & 0 & 95 & 5.3 \\
\hline & 3 & 45 & 11.0 \\
\hline & 10 & 24 & 20.8 \\
\hline \multirow{3}{*}{$\begin{array}{l}\text { 原子喖乳劑 } \\
\text { (Kodak Ltd.) }\end{array}$} & 0 & 220 & 2.3 \\
\hline & 3 & 61 & 8.2 \\
\hline & 10 & 35 & 14.3 \\
\hline
\end{tabular}

ての表で明かなるに，試料と乳劑膜との間隔 が唒す己，解像力が惡化して黑化像の線の幅が 廣くなる。他の條件が同じでも，藛真乳劑粒子 が微細でハログン銀含有率の大きい原子核乳劑 老用いる己，プロせス乾板を用いた場合より解 像力分優扎ている。

\section{$3 \cdot 2$ 試料の厚》}

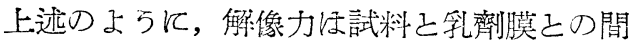
の距離が㴰すにつれて孯化する。試料が厚いと, 試料飞泟放射性同位元素が分布しているから， たとえ試料之乳劑膜とが完全に 密着していて る, 乳膜劑より離秃て存在する放射性同位元素

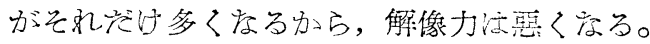

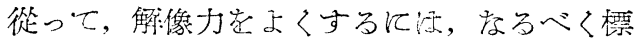
本切片起薄〈切方方が上い。乙か几，切片老作

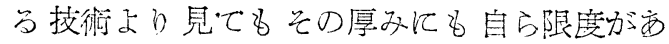
る。文, 試料中の放射性同位元素の襄度が少い

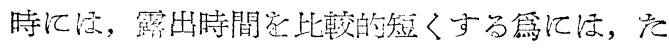
と元解像力分琶く标口ても試料切片在厚くして 試料中の放身性元溸の存在絕對量它大きく乙度 ければなら学い。特に半減期の長い放射性同位 元素の場合にはての注意が必要である。但し， $\beta$ 線のエネルギーによって定劣万試料中の拜程以 上の厚タほ無意味である。

\section{$3 \cdot 3$ 乳劑の塗布厚}

乳劑膜方溥い程解像力吱よい。第 1 圖安見る
之，ての兩者の關係に明かであるが，乳劑の塗 布厚老溥くするよりる，試料己乳劑膜との距離 及び試料の厚みの方が解像力に對して上り決定 的である。

又, 適當な露出條件注て於，乳劑の塗布厚

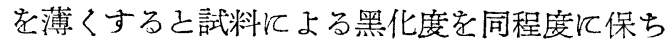
ながら，カブリ在減らすととが出來る。カブリは 後述の如く解像力を惡化させるから，ての意味 からも塗布厚怔薄い方がよい。

但し，飛跡オートラジオグラフの場合注，荷

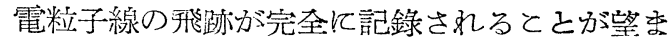
しいから，乳劑膜厚は少く已も乳劑中の飛跡程

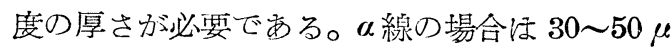
の塗布厚が必要で亩る。

\section{3・4 放射性同位元素の種類}

放射性同位元素によって $\beta$ 線のエネルギーは

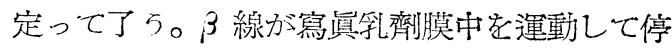
止する迄の距離, 郎ち飛程々 $\beta$ 線のエネルギー が大をい程長い。例えば, $\mathrm{P}^{32}$ では $1,400 \mu, \mathrm{I}^{131}$

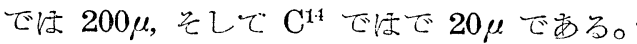

$\beta$ 線の寫自作用梩关の土ネルギーによって異 り，小さい程寫真作用が大きい。從って飛跡の 終點に近づくにつれてそのェネルギーも小さく なるので黑化作用が大きく裳る。て机解像力 を惡化させる。

$\beta$ 線のエネルギーが大きい程, 寫黄乳劑中の 飛程が長く，廣範圍が黑化され易い。即ち解像 力か低下寸る。 $\mathrm{I}^{131}$ に比して $\mathrm{P}^{32}$ の方が解像 カのよいオートラジオグラフを得るとこが覲し い。前揭の第羁表の解像力の值注 $\mathrm{I}^{131}$ 字用いて 得られをるので西るから， $\mathrm{P}^{32}$ 老使用する場合

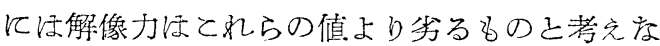
ければならない。

\section{$3 \cdot 5$ 露出 時間}

試料已寫貪乳劑膜とが密曾されてから現偤さ れる迄の時間か潽通の寫真に於ける露出時間に 相當する。露出時間が長くなるとつれで乳劑膜 の受ける及線量注增し，放射線點源汇よる黑化

(14) G. W. W. Stevens: ibid., 23 (1950), 723.

(15) G. W. W. STEVENS: Nature, 161 (1948), 432. 
範圍は次第に幛大し，同時に背景カブリも綮し

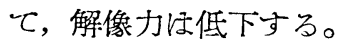

標本中に放射性同位元素が多量に存在してい 万時标, 露出時間老短くして解像力の低下老防 ぐべきである。放射性元素が少い時には，たと 元解像力々低下して子露出時間孛長くしてとに かくオートラジオグラフを作らねばをらない。

\section{$3 \cdot 6$ 現像條件}

現像度老强くすると $\beta$ 線感度は上算するが， これは露出時間索長くしたの之同じ效果老示す から，解像力在惡化させる。餘り高過ざをい現 像液溫で, 比較的短時間酒像を終る方がよい。

Stevens ${ }^{(1 \cdot 1)}$ によるこ,アミドル現像液を用い で゙ 3 分現像が適度である場合に, 12 分現像する 己感度注 4 倍に教るが解像力ほ牛分に低下し 它。

\section{$3 \cdot 7$ 乳劑の性椞}

使用す万寫訔乳劑つ性筫も亦大をく解像力应 支配する。

乳劑のハログン銀粒子が大きい程, 3 線の命 中する確率が大をく且つ及線の通過距離方長く なるので, 感度活高く度る。しかし，乃線によ って現像可能存った1個の粒于注現像處理に よって 1 個の現像銀粒子乞なり, 且つその大き さ注現像前のハロがン銀粒子の大ささに比例す るから，上ら微細な粒子の乳劑に比べでその黑 化範圍力瀇人, 解像力的低下寸る。

次に，寫眞乳劑中のハロ ゙ン銀含有率が高い

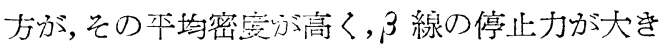
いので $\beta$ 線の乳劑中の飛程が短い。從って黑化

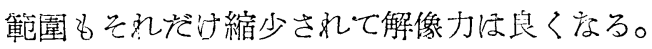

叉，一般に粒子の大きさが詓齊で揃っている

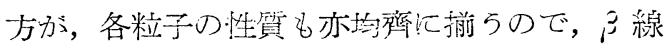
より吸收したエネルギーの僅か学差比よって現

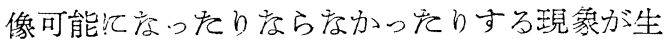
ビルくい。兄てで, 粒子の大ささり揄っていいる 乳劑崖用いを方が解像力がよい。

X線フィルム注乳劑粒于力粗大（平均 $1 \mu$ 程 度）であるか:ら，タ線感度核高いが解像力の點 で劣る。オートラジオグラフ感光材料污微細粒 子（平均 $0.3 \mu)$ で八ロゲン銀含准率 $(67 \sim 80$ \%) が大をい原子核乳劑死便用しで亦るので,
前者に比べて感度は低いが解像力汇よい。

前揭の Stevens ${ }^{(1+)}$ の賽驗結果（第 II 表）で る, 同一條件でプロセス乳劑の方が原子核乳劑 より解像力が劣っている。

背景カブリ（Background Fog）经少い方が よん。てれは乳劑の未露光粒子力現像されて生 お゙る銀粒子である。カブリ粒子が多いと解像力 忹惡化する。從って, 後述の上万郈注意化上っ てカブリ立襅力制限し学ければならない。

\section{4. オートラジオグラフの實驗操作}

オートラジオグラフの實驗操作にほ, 現在次

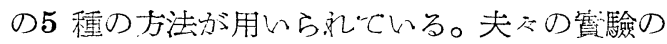
對象に應心て適用出來万最も目的几適した方法 老採用すべさである。

全ての操作に共通しを注意事項ほ次項にまと めで述べととつして，夫々の方法の詳細とそ の特長をとの發達の順索迫って說明する。その 發達注いかにして試料之乳劑膜之の密着度者向 上させて解像力庄よくするかの努力の厢史であ

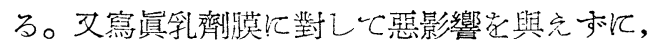
いかにして均一汇標本定染色すべきかの努力の 歴史でるある。

\section{$4 \cdot 1$ Contact Method}

この方法活第 2 圖のように，試料之乾板又は フィルムの乳劑膜面と文合せて加㻺して放置す

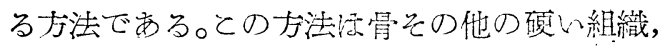

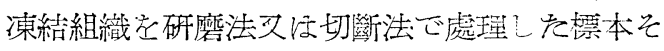
の他に用斿る。

（1）スライド硝子に標本切片索固定し,染色 し，85\%アルコール及び無水アルコール處理し を後, セロイジンの $1 \%$ エーテル・アルコール 溶液中に 2 回浸漬する, 標本は 1 夜放置してセ ロイジン老充分固的る。

（2）切片の表面寺低倍率の顯微鏡下で檢查 して、ゴミか附着してい店いとと老確める。暴 物が西ると乾板又はフィルムとの密着力゙惡くな って解像力壱低下させる原因之学る。

（3）暗室內で暗室光の下で寫畺倝板又にフ ィム（富士Xーレイ・フィム，富士プロさス乾 板，フィルム又注富士オートラジふグラフ乾板 コンククト型）の乳劑膜面の上に，スライド硝 
子標本者面を下にして心く。兩者老密着してお くには, Xーレイ・フィルムのカセットを届いる己 便利である。との際乳劑膜之標本切片との間に セロファン老1枚はさんでもよん。

（4）露出時間中，カ七ッ卜活 $1 \sim 2{ }^{\circ} \mathrm{C}$ 保保。 て必人。

（5）露出方終ったら,涟常の寫眞の處理方法 の通りに現像, 定着乙, 水洗乾燥する。

（6）出來上ったオートラジオグラフと標本

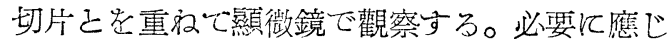
て顯微鏡舁畺应撮影する。

（7）オートラジオグラフの表面にカナダバ ルサム安 1 滴たらし、てカバー硝子で覆って保存 劣る。

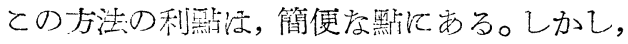
解像力飞於て劣り，高倍率飞て觀察する時にオ ートラジオグラフと標本との相當位置とを比較 するのが晎しいのか缺點で西る。

\subsection{Mounting Method(Smear Method)}

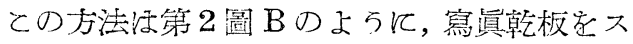
ライド硝子亡し・，只の乳劑膜の上江標本切片 直接固定する方法である。血液, 骨湔液等の中 の算細胞のオートラジオグラフを作る時には,

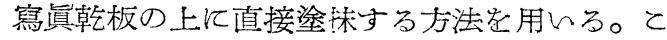
れが Mounting Method の變型で Smear Method 乙呼ばれている。

（1）標本切片染染色出秋， $40^{\circ} \mathrm{C}$ の水の中 に浮べて組織切片の㖪教く。次にて礼を18〜 $20^{\circ} \mathrm{C}$ の蒸溜水汇移す。

（2）暗室內で, 乾板（富士プロてス乾板，富 士オートラジオグラフ乾板コンダクト型）䒱 溜水中江入礼，浮いてい万組織切片它乾板の上

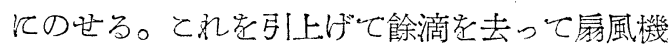
で乾燥する。

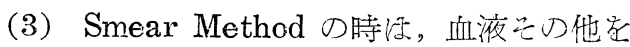
乾板上に平场に叙昧して乾燥する。

（4）露出中心，乾燥劑在入れた密閉器（デシ

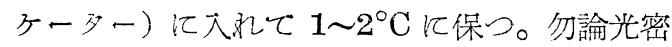
容器でなけ剠ば症らない。

（5）露出が終って現像處理化入る前汇組織 標本の脫パラフィンをしをければをら宗ん。純 キシロールに1分間浸寶する處理它 2 回繰返し た後暗室內で完全にキシロール蒸發し去る。 通常換氧の充分行わ礼ている暗宝內机ば 15 分間でよん。Smear Methodの時ねとの處理は 必要で法存ん。

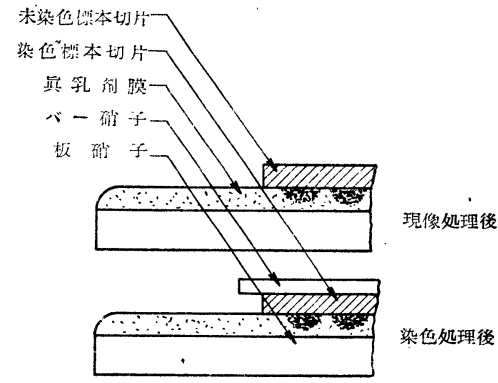

B. Mounting Methot.

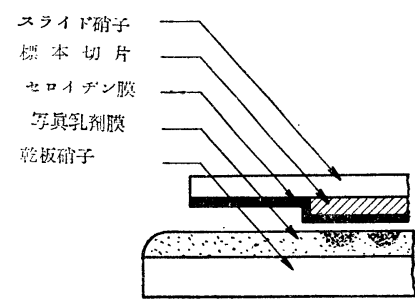

A. Contarit Method

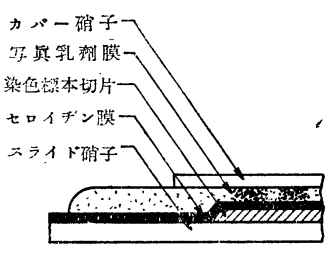

C. Coating Nictiod

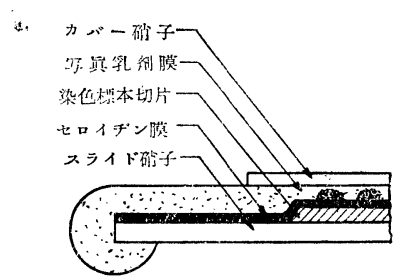

1). Strimping Emulkion Methou

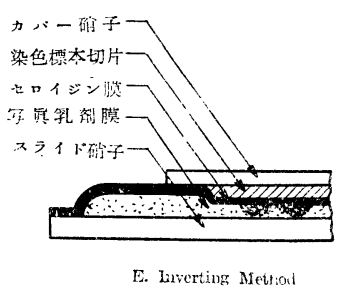

E. Liverting Mettoil

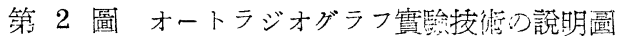




\section{（6）現像定着處理活 $18 \sim 20^{\circ} \mathrm{C}$ の液溫で行} 5。

（7） $20^{\circ} \mathrm{C}$ 以下の流水中で 20 分間水洗し 後で, 1 $2^{\circ} \mathrm{C}$ で稀薄へマトキシリン染色液中 に1夜放置する。稀薄溶液を用いるの注乳劑膜 の主成分であるゼラチンを染色し過ぎないよう

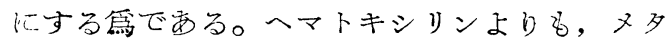
ニル黃之鐵へマトキシリンの組合せの方が、”乳

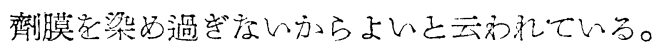

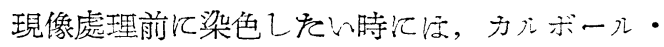
フクシンさニニートラル・レッドの組合せ方現像 液によって脫色され高的からよ上云和礼てい 万o

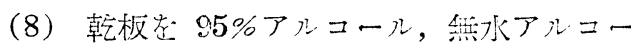
ル，アルコール・キシロールの順汇炃长虎理し キ後, キシロール浴岸 3 回反復してから, バル サムこ標本上にカバー硝子崖貼りつげ。

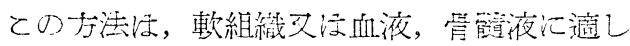

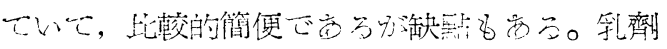

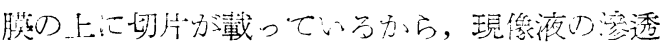

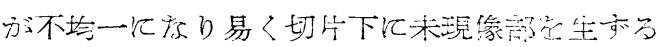
ここが雪る。ゼラチンが染色さ礼易、のごー

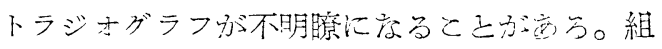

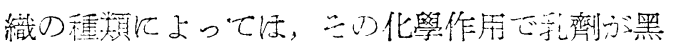
化さ礼らて上がある。

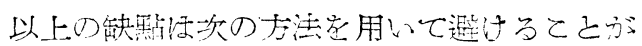
所來る。

\subsection{Coating Method}

との方法涂，第2圖Cのように，スライド硝 子の、上に固定した標本切片の上に融解した竄買 乳劑老均一溥人塗布する方法で亩ら。乙のお 洼の優礼ているの酒標市之乳劑膜とつ密着度が 最もよく，從って解像力方よん熙で方っ。しか し，操作が極めて複雜で熟練を咹し，使用する 器物並びに操作江對して充分過ざる注意定椇わ ない之，乳劑にカブリを生で良好界が德られな

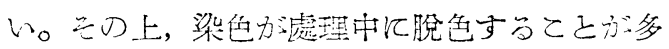
いのも缺點で西る。染色宾一切行わ和位相熟 徽鏡で觀察するもの多よい方法で亩う。

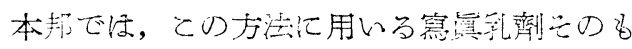

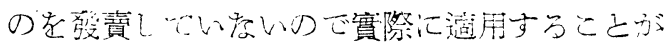
蜼しい。
（1）切片 (染色又注未染色) 芆スライド硝子 に固定したものを Contact Method と同樣に セロイジン膜で覆ら。

（2）スライド硝子上㳊切片索中心乞して1时

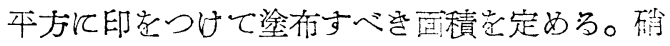
子の裏側にインクス注ワックス鉊筆で印学つけ ろとよい。

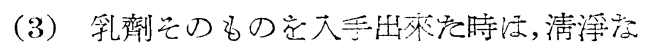

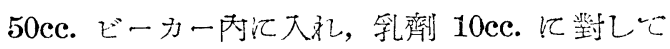
$3 \sim 6 \mathrm{cc}$. の蒸溜水老加充て, $37^{\circ} \mathrm{C}$ の水浴学用!

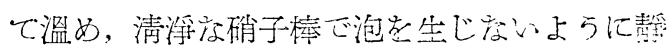

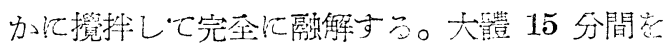
敢する。

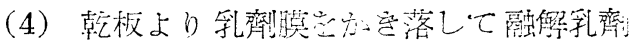

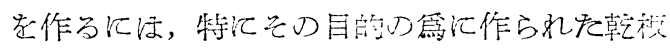
老用いなければならない。富士オートラジオグ ラフ乾板はコンタクト型もストリップ型る乳乵

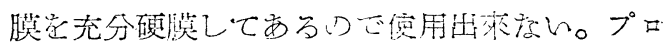

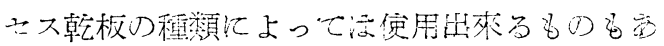

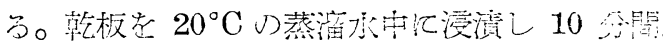

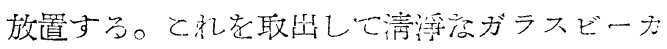

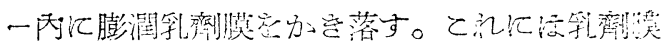

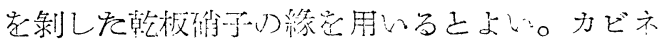

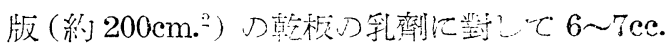

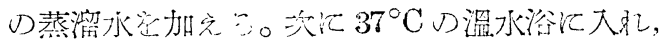

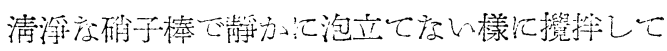

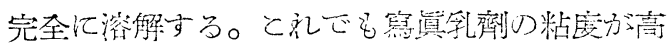

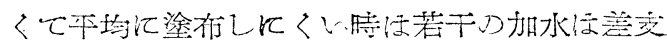

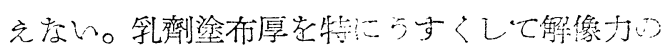

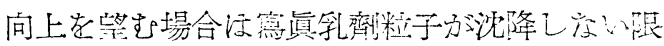

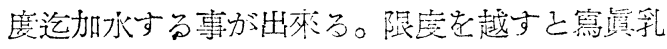

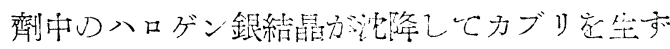

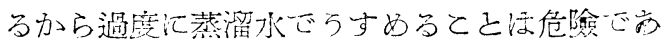
る。

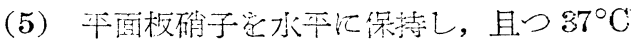
に温めて出く。との上にフライド硝子岕のせる。

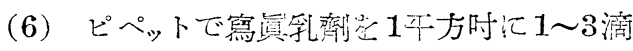

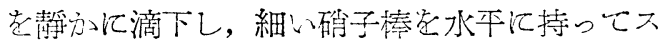

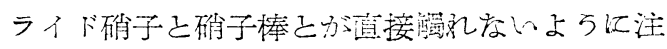

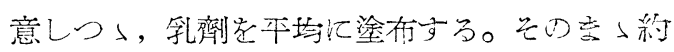
$1 \sim 2$ 分間 $37^{\circ} \mathrm{C}$ 汇保つ。

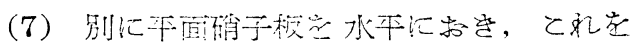


0〜5 ${ }^{\circ} \mathrm{C}$ 亿冷却しておいた上に, 叙布し終って スライド硝子を格いて, 竄置乳劑在冷却凝固さ せる。

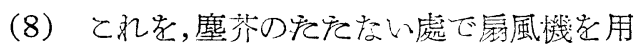
いて急速に乾燥与る。

（9）幹燥劑老入玌たデシケーダーに大れて 1 $2{ }^{\circ} \mathrm{C}$ 亿保ちつ小露出する。

（10）現像定着趬理定行5。cの際, 酸性定

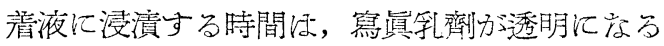
に椞する時間の 1.5 倍に正めて, 直ちに水洗沉 移し，極力染色方脫色されるの孛防ぐ。

（11） $20^{\circ} \mathrm{C}$ 以下の流水で 15 分間水洗し它 後, $95 \%$ アコール浴 3 分, 堑水アルコール浴 3 分, アルコール・キシロール浴 3 分, キシロ 一ル浴 3 分 3 回老經て脫水乾礐する。

（12）バルサム孝用いカバー硐子で覆っでか 方，綮微鏡で觀察すう。

\section{4. Stripping Emulsion Method}

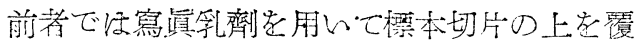

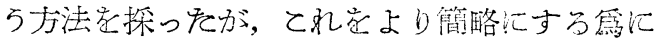
考菜さ礼を方法で西る。(第2圖 D)

本邦では，ての方法り雼に富土オートラジオ グラフ乾板ストリップ型があら。

（1）切片 (染色又ほ未染色) 忩天ライド硝子 に固定したもの娄, Contact Method 上同樣江
セロイジン膜で覆ら。

（2）次沃トリップ乾板を $1 \times 3$ 时のま $20^{\circ} \mathrm{C}$ の蒸溜水老入れを硝子血江浸漬する。約 2 〜3分の後乳劑膜が充分膨潤してから,左手で乾 板を持ち右手の人差指の腹で乾板の一方の緗か ら乳劑膜家靜かにてすると, 直汇乳劑膜の緣が 硝子より剝狆る。てれを右手でつるんで静かに 区射側汇引くと容易汇乳劑膜のみが剥離する。 硝子板定除いて，代りにスライド硝子索水中に

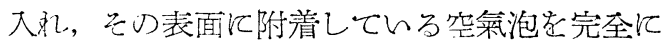
除く。次汇左手でスライド㗂子起標本面孛上に して持ち, 水中で乳鈹膜孝平らに廣げて(ての時 乳劑膜の面積任 $1 \times 3$ 时上り大き(なっている) 靜かに泡が大ら亦，異物が中間に大らす，解が よらないよらに注意しつょスライド硝子を引上 げる。餘滴を湑紙で除いて扇風機で乾燥する。 (第 3 圖參照)

ストリップ・フィルムは第 4 圖Bの構造を持ち， 乳劑膜とゼラチン膜とが共汇剝机るから，乳劑

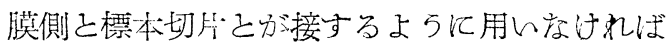
なら交い。ストリップ乾板で战，第4圖Aの上

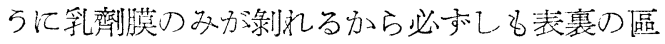

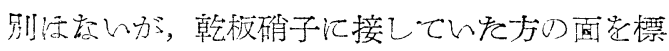
本切片汇接した施がん。

（3）現像處理以降の操作活Coating Method

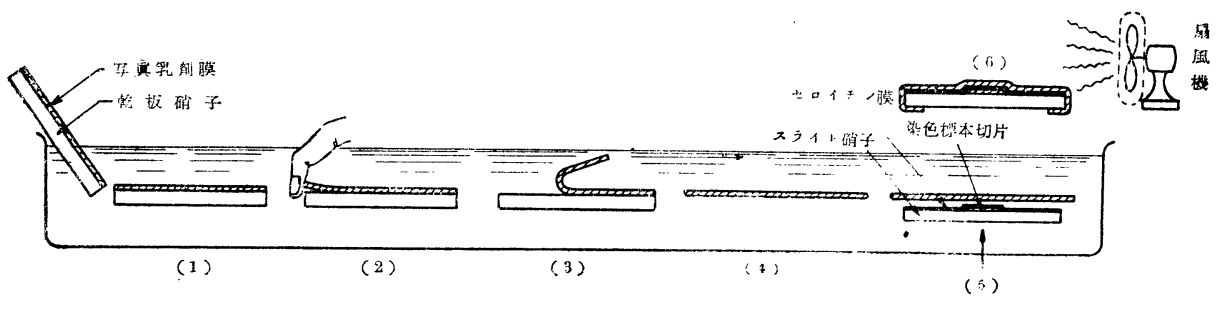
（1）ストリッピング乾被定水中に大える

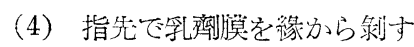

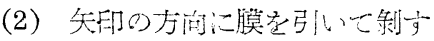
（5）乳剂膜を水平に廎げる
（3）スライド确子在下に大虬て引上げる
(6) 乾燥して露出に大る

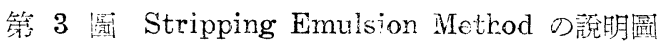

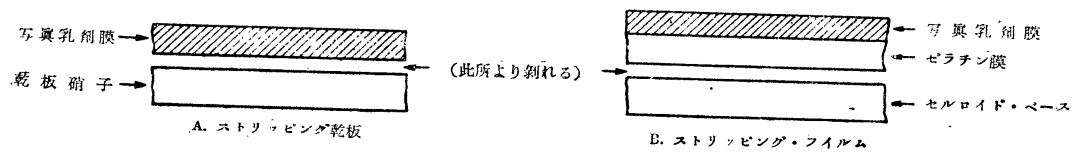

第 4 圖 ストリッピング乾极・フィルムの權:造 
己全く同樣で两方。但し, 乾燥處理汇よって乳 劑膜がスライド硝子より利膜する時注，1\%グ リ七リン浴汇 2 分間浸渍してから自然乾燥させ るとよい。

との方洼活 Coating Method 乙同樣つ解像 力を持ったオートラジオグラフがより簡便飞特

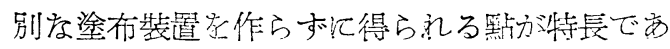
るので，現在廣く筫用されている。

\subsection{Inverting Method}

Coating Method 䚺びその變型 Stripping Emulsion Method で染色操作活常汇初め汇行

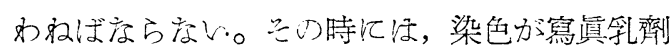
に惡影響索與えるて之も西り又染色が處理中に 脫色するととb市り, 或心注染色操作中の放射 性同位元素が流出したり標本の他の部分に移動

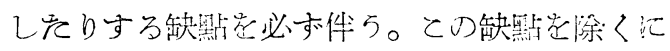
ほ, 染色操作它最後に行らのか理想的である。

この理想老珼現したのが，ての Inverting Method である。大蹬住 Stripping Method と同じ方法であるので，解像力の點もオートラ

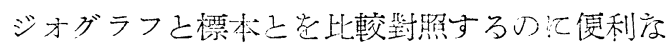

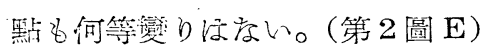

（1）スライド硝子上江固定した禋本瓜染色 し店いで报く。セロイジン膜で覆う。

(2) Stripping Emulsion Method 上同じ。

(3) 現像定着水洗迄活 Corting Method 及び Stripping Methed 上同樣汇行ら。

（A）水洗が終ったスライド确子它, 水中们てて
安全剃刀の薄い刃先を用いて, スライド㗂子よ り乳劑膜を標本之共汇剝し取る。乙的孝裏返し て標本を上面として新しんスライド硝子上につ せてて水中より引上げる。（第 5 圖）

（5）乾燥したら，乳劑膜の䦌邊汇 1\%さロイ ジン液を叙っでスライド硝子より剝剠い上ら 飞する。充分セロイジン膜を乾燥する。

（6）乙学染操作汇移す。乳劑膜》上注 セロイジン膜で覆われているから乳劑膜が染色

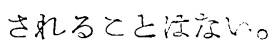

（7）乾燥後，カテジ・バルサムでカバー硝子 老貼布し，禞鏡する。

\section{5 感光材料つ撰定}

晲在本邦で入出來万感光材料の內カートラ

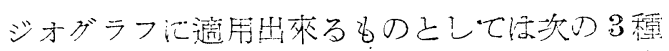
行站方。

\section{5・1 X線フィルム}

$\mathrm{X}$ 線フィルムに用いられている寫寊乳劑う粒

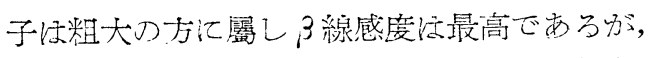
解像力で注最当劣っている。Contact Method 起用いて Macroautoradiograph在作ら汇適し ている。

富士X線フィルム, 富士 $\mathrm{X}$ 線薪科用フィルムが てれで市。

\section{$5 \cdot 2$ プロセス乾板及びフィム}

プロせス乳劑注前揱と後者との中間の六焉さ の乳劑粒子より成り，との及線感度孔中間であ

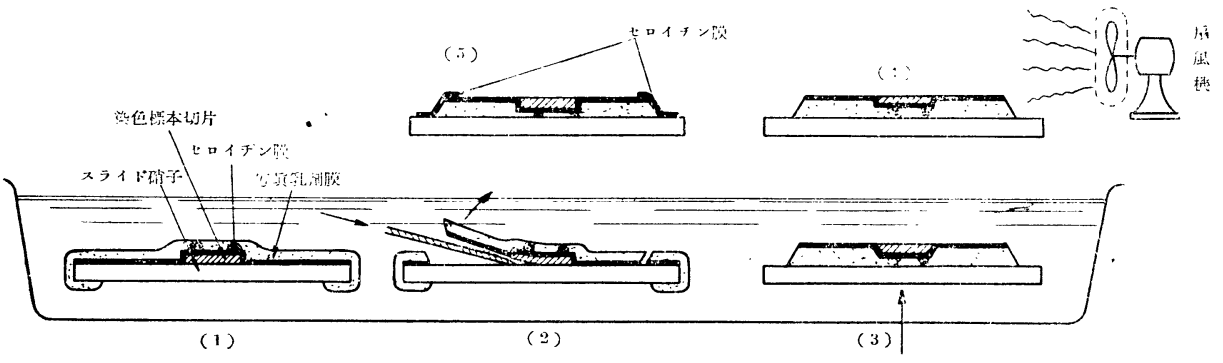

（1）流水中で $20^{\circ} \mathrm{C}$ 15〜20 分間水洗する

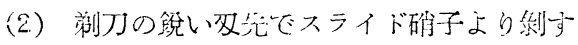

（3）これを裹涯して新しいスライド确子に战附汁て水より引!上げる

(4) 乾燥する

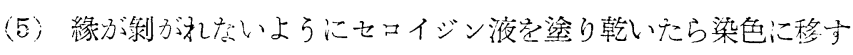

第 5 圖 Inverting Method の說明圖 
ろ。Contact Method 及び Mounting Method 應用出來る。

富士プロセス・フィルム及び乾板がこれであ る。

\section{$5 \cdot 3$ オートラジオグラフ用乾衵・フィルム}

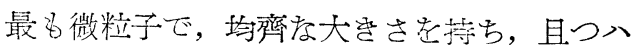
ロゲン銀密展る現行の乳劑中最大で市る。從っ

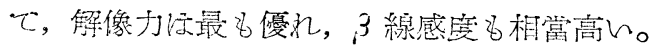
ての乳劑任宇宙線研究气の他の原子核物理學の 蕒驗它用いら礼ている。

富士オートラジオグラフ乾板コンタクト型 注 Contact Method 及び Mounting Method

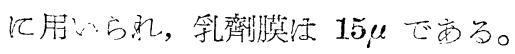

富士オートラジオグラフ乾板ストリップ型は Stripping Emulsion Method 及び Inverting

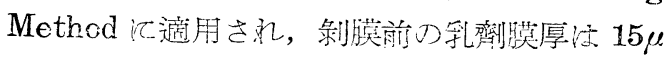

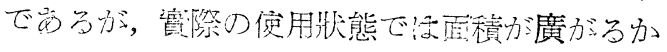

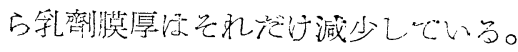

\section{6 各實驗操作に共遍な注意事項}

上述のオートラジオグラフ技術の個くに共通

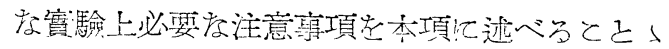
する。

\section{6・1 露出時間の決定}

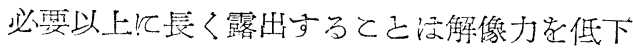
させるので避け祮ければ店らない。

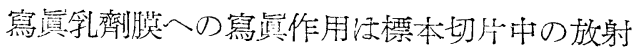
性同位元素の局所的濃愿で定委万ので两るか ら，切旨中の放射性同位元素の總量をガイガー ・ミニーラー計喽管その他在用いて測定してもと

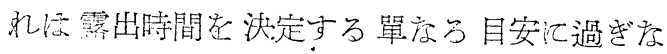
い。陚料全娟としてては省量でも標本の一部行集 中している時窞買作用が大を゙いからである。 但し，同樣な寶驗死区復する場合汇添，ガイガ 一訫數管の讀み己最適露出時間乙つ關係が豫め 記録されていれば，ガイガー計數管の測定值で 露出時間它定めるとこが出來っ。

一般的には，使用する放射性同位元素の種類 によって $\beta$ 線のエネルギー, 牛減期が異るし, 實驗材料比上っ・C放射性同位元素つ局所的濃度 が異り，實驗の目的沉よりオートラジオグラフ に要求する解像力夕異るので, 標準的な露出時

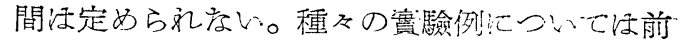
項怠參照されたい。

そてで，次の方法在推獎する。

寶驗試料之全〈同樣の方洼で，露出時間压決

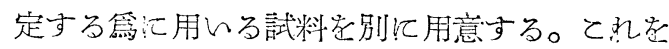
西万時間間隔で（1日，2日，4日，8日，16日， …‥万5に等比級數的红露出時間索變化させ て）現像し檢鏡してて，その䔬驗目的飞適した黑 化狀態の得られを時江, 全部の賈騟試料の露出 达打切っ・同時江現像する。乙の際使用乙そ放 射性同位元素の坐減期の 4 倍以上の露出時間怘

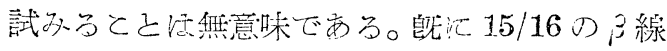
は利用しをの心亦るから。

そとえ，ガイガー計數管で計數出來ない程度 の微弱な試料でる，放射性同位元素が局所的伿 集中している時沉に， $\beta$ 線のエネルギー在積分 出來るか:ら，露出時間索長くすれば寫買乳劑膜

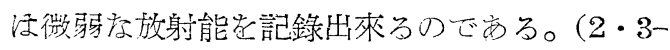
1 (8) 寥照)

\section{$6 \cdot 2$ 露出時 及び 保存中の溫濕度條件その 他の注畫事項}

寫真乳劑膜の性質汪，製造後保存している間 に，徐ミで泟西万方變化して行く。又寫真乳劑

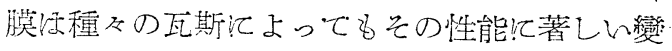
化起受けるから, 保存及び露出沉際して注意し なけ就ば学らない。

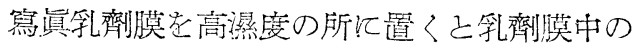
平衡水分が霄す。するとカブリの唂生速度，感

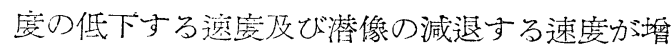
大寸る。その上，高溫行るとその變化仗又促 潐される。

又寫真乳劑膜活 $\mathrm{H}_{2} \mathrm{O}_{2}, \mathrm{H}_{2} \mathrm{~S}, \mathrm{SO}_{2}$, 亞砒酸, アンモニア，水銀蒸氣行ふれとカブリ老生ず る。金屬表面，ペンキ塗裝面，テルペン油等に ふ剠ててる影響される。動植物體組織とよって乳 劑膜江惡影響老與元万場合もある。

そこで, 露出中も保存中も低溫低濕江保ち有

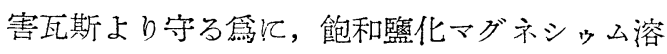
液考入れた密閉容器（デシケーターがよい）江 入れて冷藏庫中汇入れでくのがよい。

但し, ての際に低溫の場所上り直飞室內儿取 出すと, 室內の水蒸氣が乾板フィルムに水滴之。 
なって凝縮する危險がある。從って，低濕の場 所より容器でと取出して, 室溫と平衡してから, デシケーター中より取出すと云ら注意意って はをらない。

動稙物體組織の種類汇よっては, 乳剂にカブ リを與えたり感度を低下させるものも西るか ら, 得られたオートラジオグラフ方確か沉 $\beta$ 線

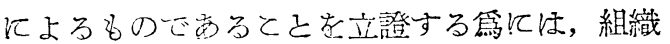

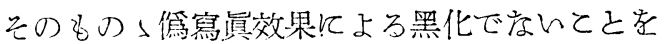

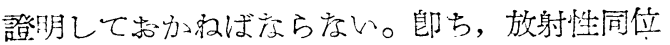
元素に上万處理老行ってい存い試料它用いて全 く同樣つ實驗支平行的飞行って, その乳劑膜沉 黑化現象のないと之確めて执力をけ机ばなら 存的。

$\mathrm{X}$ 線や $\gamma$ 線忹透過力が强く, 寫䢙作用支有す るから，保存中露出中无加万放射線上り完 全飞遮斷しなければならない。放射性活染飞關 しても嚴重汇注意しはけ就ば存らないるは勿論 のととである。

\section{6・3 染色液の寫暻乳劑膜への影響}

現象處理後染色操作龙行ら場合や，染色䅺本 切片をセロイジン膜で完全汇覆った場合汪一應 染色液の影響柱無視出來る。

筆者つ實驗 ${ }^{(16)}$ 亿よると, ギムザ氏染色液, メ ーグリュンワルド氏染色液は激しく減感するか ら, 乳劑膜又注乳劑中滥微量でも附着したり混 入したりするととは嚴汇避けねばならない。

\section{6-4 機械的刺戟の寫貝乳劑膜への影響}

竄真乳劑膜は强い靜壓を加えても, 輕く摩擦 してもカブリ岩生ボる。特沉機械的摩擦汇對し

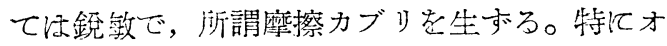
一トラジオグラフ用感光材料注，一般の感光材 料と異り，試料と乳劑膜との密着度を上げる零 にゼラチン保護膜老塗ってい店いし，ハロゲン 銀粒子の含有率も高いから摩擦カブリを生ざ易 n。

從って感光材料の取扱い注機栈的摩擦学與元 ないよら汇丁寧汇静かにしなければならない。

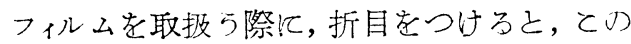
刺戟でも折目のマークが黑く大るから注意昰要
する。

水の中で取扱ら時は, 乾燥狀態に比べて比較 的機械的刺㦸つ影響任少々。

\section{$6 \cdot 5$ セーフライト}

暗室內の照明汪，X線フィルムに注富士5 號 セーフライトグラス，プロセス乾板，フィルム 及び富士ホートラジオグラフ乾板,フィルムにに 富士 3 躆レーフライトグラスを用い，10蜀つ笔 球老用いて $50 \mathrm{~cm}$. 離れ小ば安奎行取报 が出來る。富士ューフライトランプ在用的る が最子便利で㐫る。

\section{$6 \cdot 6$ 現像條件}

現像液活富士レンドール現像劑在用い万か, 又は FD-111 處方衣用いて $20^{\circ} \mathrm{C} て ゙ 2 \sim 4$ 分現 像する。

FD-111

$\begin{array}{lr}\text { 溫湯 }\left(50^{\circ} \mathrm{C}\right) & 500 \mathrm{cc} . \\ \text { モノール (メートル) } & 4 \mathrm{~g} . \\ \text { 無水亞硫酸ソーダ } & 60 \mathrm{~g} . \\ \text { ハイドロキノン } & 10 \mathrm{~g} . \\ \text { 無水炭酸ソーダ } & 4.5 \mathrm{~g} . \\ \text { ブロムカリ } & 2.5 \mathrm{~g} . \\ \text { 水を加えて } & 1,000 \mathrm{cc} .\end{array}$

水で 2 倍汇稀釋して使用する。

\section{6-7 定着條件}

富士フィックス定着劑吉用いるか, 又注 $\mathrm{FF}-\mathrm{H}_{2}$ か $\mathrm{FF}-\mathrm{H}_{4}$ 處力を用いて， $20^{\circ} \mathrm{C}$ で乳劑膜が透 明になるの汇要した時間の約 2 倍の時間定着す

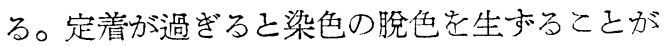
西る。又，長時間定着すると，現像銀力溶解し て黑化度が減少する。Smear Method ご注細 胞の溶解をさける爲江醋酸を含まない定着液孝 用いた方がよい場合も西る。

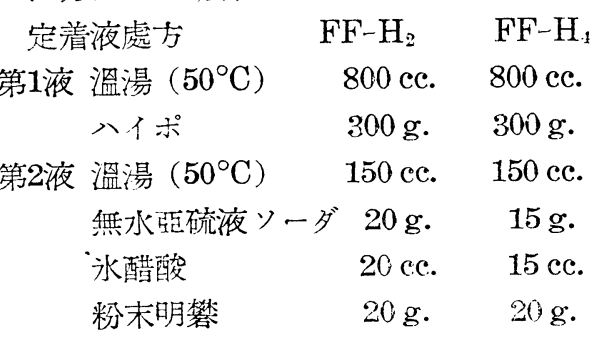

（16）古關靖夫：ラジオアイソトーブ講相會講議錄（京大), (1952), 119〜136. 
冷却した後, 第 1 夜它攪挥しながら, 徐々飞第

2 液を加え，“水老加えて 11 l. こする。

$$
\text { 富士ナボックス }
$$

$12 \mathrm{~g}$.

第 1 夜, 第 2 液䘮別及の器飞溶解し, 常溫に

\section{$6 \cdot 8$ 水洗乾燥條件}

水洗は流水中で 15〜20 分行えば充分である が，水溫け $20^{\circ} \mathrm{C}$ 在嚴守しはければならない。

よく表面の塵芥や水滴艺拭々去って, 乾燥し を塺芥のない部屋で乾燥する。若し乾燥中深剥 膜す万叔と礼の西万時法，1\%グリセリン水溶 夜汇 10 分間浸漬してから乾燥すると剥膜老防 ぐことが出來る。

\section{7 結 語}

オートラジオグラフ用感光材料の試作研究に 從事しているものとして，見聞し調查した事項 在骨子として，蕒際行ートラジオグラフ安實

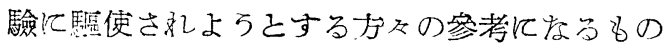
をと思いつ〉，理論的事項を最少限红止めて稿 达淮めを。果して筆者の念願する所が達し得ら 礼をのかにら力疑なき崖得ない。大方の御叱正 在待つ次第で㐫る。若し實驗者飞僅かなり己も

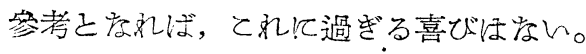

H. YAGODA: Radioactive Measurements with Nuclear Emu'sions, John Wiley and Sons Inc, New York, (1949), 217 253.

R. H. HERZ: Nucieonics, 9 (1951), 24 39.

J. Gross, R. Bogoroch, N. J. NAdLeR and C. P. Leblond: Amer. J. Roentgenology, 65 (1951), 420.

湯淺年子：放射性同位元素々 その生物學醫學への㮣用, 培風館 (1951)，75 79.

古關靯夫：日本寫筫學會誌, 13 (1951), 81.

古關靖夫：機諓の研究, 3 (1951), 333.

古關嗉夫：ラジオアイソトープ講㿟會豫稿（於京都大學），(1952），119１36.

古關靖夫：科 學, 23 (1953), 150 1555. 
第三日 $(8$ 月 26 日) 午前

放射悩同位元素の農學への應用

条大農學部敉授 三 并 進 午 